\title{
EXPRESSÃO GÊNICA DIFERENCIAL DURANTE $O$ DESENVOLVIMENTO E NA RESPOSTA AO CHOQUE TÉRMICO EM Blastocladiella emersonii
}

Tese de Doutoramento apresentada ao Departamento de Bioquímica, Instituto de Química, Universidade de São Paulo

Orientadora:

Dra, M A R I A H L EN A J UL I A N I

SÃO PAULO

1987 
Aos meus pais, Célia e

Wanderley, porque me ensinaram que "...é preciso ter força

é preciso ter raça

é preciso ter manha

é preciso ter graça

é preciso ter sonho sempre..."

(M. Nascimento e F. Brant) 
Agradeço a Dra. Maria Helena Juliani pela seguranca e dedicagaro com que desempenhou seu papel de orientadora e, principalmente, pelo incentivo amizade tao constantes nestes quatro anos de convivio. 


\section{AGRADECIMENTDS}

A Dra. Maria Christina M. Bonato, que participou, direta e intensamente (aqui ou lá na LIFPb), dos estudos sobre a resposta oo choque termico apresentados nesta tese, agradeço pelas estimulantes discussoes envolvendo "desdea bactéria até o homem".

A Dra. Suely Lopes Gomes, pela ajuda com as imunoprecipitaç8es e "Northern blots"e, também, pela revisgo minuciosa do manuscrito desta tese.

Ao Dr. José Carlos da Costa Maia, pelo apoio e sugestres, cientificas ou nyo, durante a realizaço deste trabalho e também pela leitura critica do manuscrito.

Ao J. Janduí da Costa Rraújo, estudante da UFPb que sob orientaço da Dra. M.C.M. Bonato, realizou vários experimentos sobre a sobrevivencia celular após induggo de termotolerância.

A Lilian C. Etchebehere, Marilis do Vale Marques, Maria Margarita Behrens, Marcelo Avedissian, Marcelo Briones, Glaúcia M. Souza, Fátima P.R. de Melo, Dr. Bayardo B. Torres e Dra. Lélia Mennucci, pela agradál convivência e pelas divertidas conversas.

A Maria Alves e ao Mário Lopes, pelo eficiente auxilio técnico. A Marli Cunha da Silva, pelo cuidado com a limpeza do material e principalmente pelos bons conselhos.

Aos Drs. Cecilia L.S. Santos e Ricardo R. Brentani pelo fornecimento do lisado de reticulocitos e ao Dr. Samuel Goldenberg pela ajuda nos experimentos iniciais de traduça "in vitro".

A Dra. Maria Júlia Manso Rlves pela orientaça no estabelecimento da técnica de "immunoblotting" bem como pela colaboraçáo na nossa tentativa de obtença de anticorpo contra Hsp70.

A Dra. Annamaria 5. Stolf por ter colocado o seu Laboratório a nossa disposicgo quando fizemos nossa primeira deteç̧o imunoenzimática.

A Margareth L.C. Guimarges, pela boa vontade com que nos ajudou a imunizar os coelhos. Afinal nós tentamos, os coelhos é que foram os culpados... 
Ho Dr. J. Daniel Lopes por ter nos cedido o anticorpo anti-IgG de rato e a Glaucia 5 . Paranhos pela gentileza em nos ceder anticorpo anti-Igt de coelho conjugado a peroxidase além do reagente diaminobenzidina.

Mo Juan J. Lafaille por ter conseguido anticorpo anti-IgG de camundongo e ao Dr. Renato Mortara por ter nos cedido actina purificada.

Um agradecimento especial aos Drs. C.P. Georgopoulos, S. Lindquist e E. A. Craig que gentilmente atenderam nosso pedido enviando os anticorpos anti-Dnak, anti-Hsp70 e o plasmídeo B8, respectivamente.

Ao Onofre custodio da Silva, mais conhecido como Célio fotógrafo, pela paciência com que "documentou" nossos preciosos resultados.

Ao Leonardo Van Halsema por ter me ensinado a operar o microcomputador facilitando assim meu propósito de "bater a tese no computador".

Ao Dr. Isaias Raw por permitir que eu terminasse a tese sem ter que me preocupar, por hora, com o meu novo e futuro compromisso com o Laboratório Especial de Biotecnologia do Instituto Butantan, onde fui recentemente contratada no cargo de Pesquisador Científico.

Aos professores e colegas do Departamento de Bioquímica, em especial ao pessoal do 12, pelas diversas sugestres, pelas cervejas quando possivel e sobretudo pela convivencia dialética nesses corredores.

Ao Armando M. Ventura, por tudo e mais um pouco, mas principalmente porque me mostrou essa alternativa profissional.

Este trabalho foi realizado como auxilio financeiro da FAPESP, FINEP e [NPq aos Drs. Maria Helena Juliani, Suely Lopes Gomes e José Carlos da Costa Maia. A autora foi bolsista da FAPESP de agosto de 1983 à marco de 1987. 
ABREVIATURAS ..................

RESUMO ........................ 2

SUMMRRY...................... 7

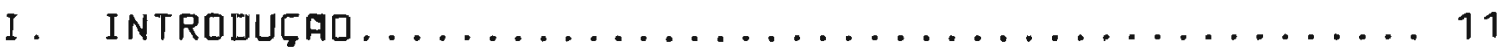

II. PROCEDIMENTOS EXPERIMENTAIS............... 41

1. Condiçós de cultivo e obtençao das células....... 41

1.1. Manutençăo das culturas e obtençă dos

zoósporos de primeira geraçao............41

1.2. Cultivo em meio líquido PYG-P para obten-

ça de grandes quantidades de zoósporos......4 42

1.3. Induçao da esporulaçăo e germinaçăo sincrónicas........................ 42

1.4. Condiços para o tratamento térmico das

células......................... 45

1.5. Incorporaça "in vivo" de josjimetionina......4 46

1.6. Incorporaçăo "in vivo" de azpi ...........4 47

2. Extraçao das proteínas totais das células para analise em eletroforese em gel de poliacrilamida.... 47

3. Determinaça da radioatividade incorporada em proteínas........................... 48

4. Extraça e purificaçăo de RNA............... 49

4.1. Dbtençăo de RNA total................. 49

4.2. Purificaçăo de RNA poli(

5. Traduçăo do mRNA em lisado de reticulócitos de coeltho........................... 52

6. Eletroforese de proteinas em gel de poliacrilamida contendo $5 D 5 \ldots \ldots \ldots \ldots \ldots \ldots \ldots \ldots \ldots$

6.1. Eletroforese unidimensional............. 53

6.2 . Eletroforese bidimensional............. 54

7. Procedimento para obtençăo de mapa peptídico

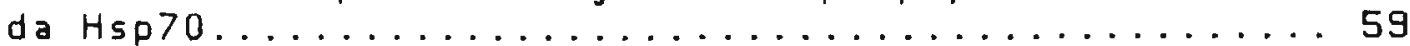

8. Eletroforese de RNA em gel de agarose..........59

3. Transferência do RNA para filtros de nitrocelulose e hibridizaçgo RNA/DNA............ 60

10. Ensaio de imunoprecipitaçăo...............61 
11. Deteçăo imunológica de proteinas imobilizadas em filtros de nitrocelulose

("immunoblotting")......................63

11.1. Transferência eletroforética de proteínas de geis de poliacrilamida para filtros de nitrocelulase.............63

11.2. Deteç̧a imunológica das proteínas do "blot".........................63

12. Purificaça de tubulina de $f$ lagelo de

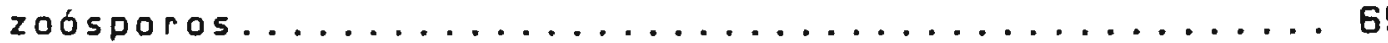

13. Separaça dos derivados fosforilados da

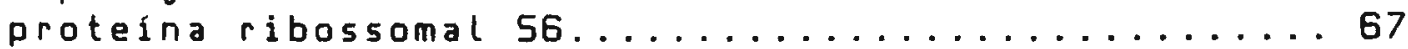

13.1. Extraça de proteínas ribossomais...........67 67

13.2. Eletroforese bidimensional para separaça dos derivados fosforilados de $56 \ldots . . .68$

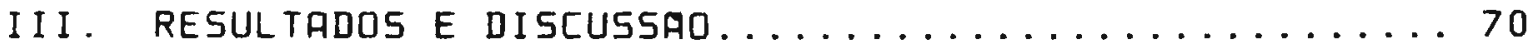

1. Análise das variaçós no padrăo de sintese proteica durante a esporulaçăo germinaça em Blastocladiella emersonii................770

1.1. Sintese de proteinas durante a esporulaça..... 70

1.1.1. Obtençăo das proteinas totais na ausência de proteólise................ 70

1.1.2. Padrao das proteinas sintetizadas "in vivo".................... 73

1.1.3. Traduçăo "in vitro" de RNAs isolados durante a esporulaçåo............... 83

1.1 .4 . Discuss zo..................... 90

1.2. Sintese de proteinas durante a germinaça...... 95

1.2.1. Padra das proteínas sintetizadas durante a germinaçåo em soluçăo inorgânica...... 97

1.2.2. Padrăo das proteínas sintetizadas durante a germinaçăo em meio nutriente AL ...... 103

1.2.3. Traduçăo "in vitro" de RNAs isolados durante a germinaçăo............... 107

1.2.4. Modificaçชes pós-traduçăo das proteínas de zoósporos durante o inicio da germinação....................... 109

1.2 .5$, Discuss ชo ........................ 113

1.3. Identificaçăo de três proteínas cuja sintese é controlada pelo desenvolvimento: actina, $\alpha$-tubulina e $\beta$-tubulina.................... 118

1.3.1. Variação no acúmulo de actina, a e $\beta$-tubulinas durante o ciclo de vida....... 124

1.3.2. Regulação da síntese de actina, a e $\beta$-tubulinas durante a esporulaçăo...... 124

1.3.3. Discussăo..................... 130 
2. A resposta ao choque termico em Blastocladiella

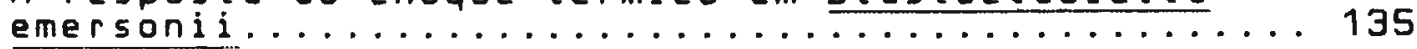

2.1. Expressa diferencial das proteínas de choque térmico durante o desenvolvimento.......... 135

2.2. Confirmaça da identidade entre a proteina de $70 \mathrm{kDa}$ induzida espontaneamente na esporulaço

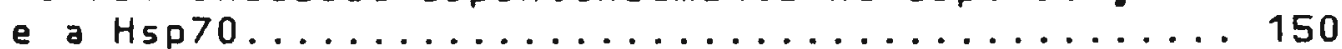

2.3. Induçăo de termotolerância durante o desenvalvimento de . emersonii.................. 156

2.4. Discussรo......................... 163

3. Efeito do choque térmico na fosforilaça da proteina ribossomal 56 de B. emersonii........... 169

3.1. Discussăo........................ 179

4. DISLUSSAD FINAL .................... 183 REFERENCIAS BIBLIOGRAFICAS. . . . . . . . . . 195 


\section{ABREUIATURAS}

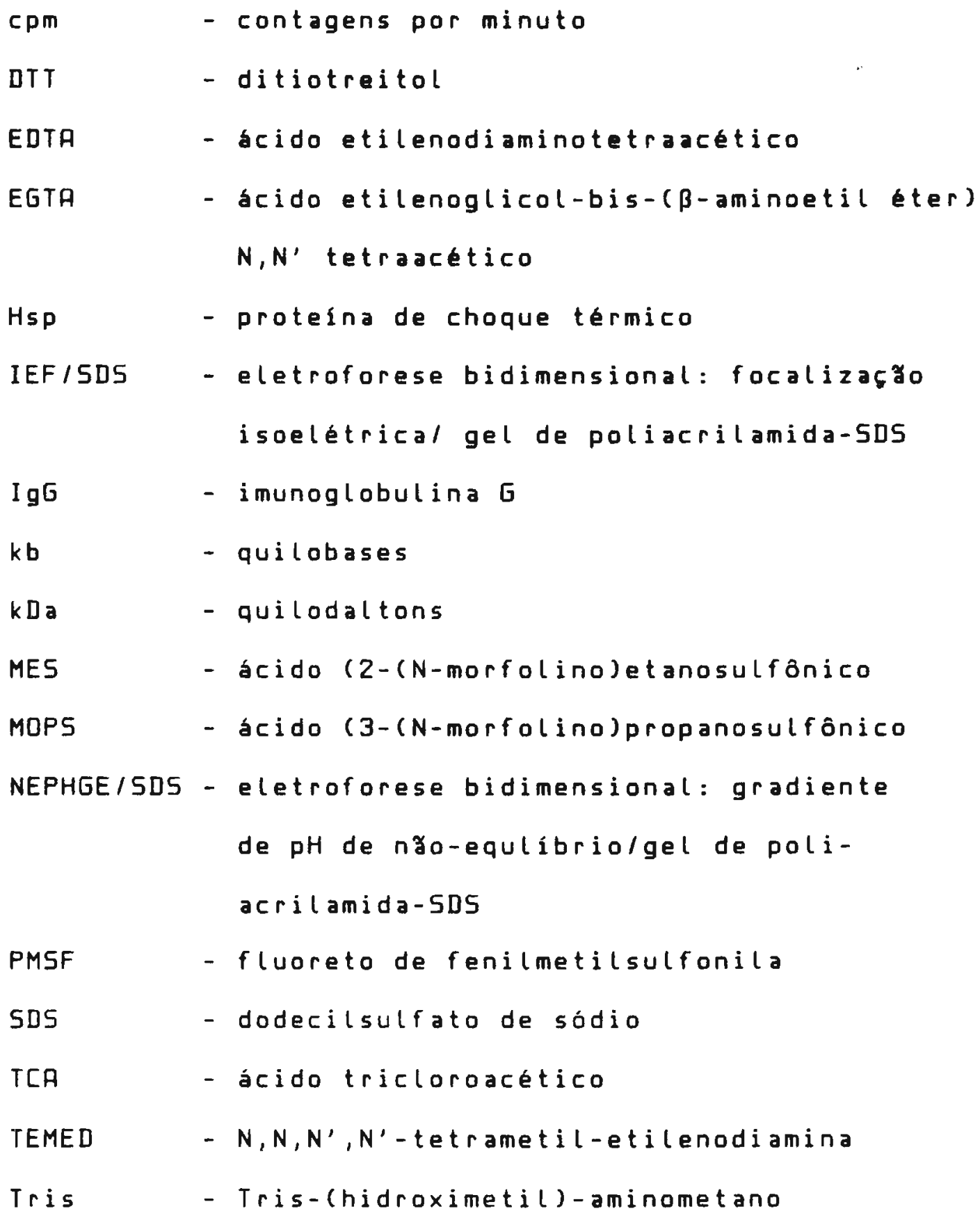


RESUMD

Usando incorporação "in vivo" de lasos/metionina, traduça "in vitro" de RNA e eletroforese bidimensional, iniciamos um estudo do controle da síntese de proteínas durante duas fases distintas de diferenciagao celular, a

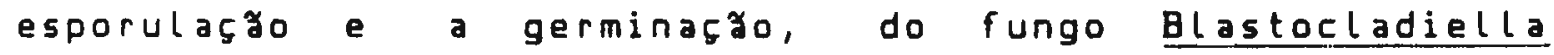
emersonii.

Durante a esporulaça ocorre uma intensa variaço no padrá de sintese proteica. Foi analisada a sintese de 108 proteínas, sendo verificado que o aumento na sintese de várias proteinas está associado com estágios definidos da esporulaçăo. Um grande número de proteínas básicas é sintetizado exclusivamente no final da esporulaço, que corresponde à fase de diferenciacgo dos zobsporos. Também foram detectadas drásticas variaçóes na populaça de mRNAs ao longo de toda a esporulaçăo. A sintese de várias proteinas típicas da esporulaça parece ser controlada ao nivel da transcriçăo. Além disso a maioria dos RNAs mensageiros específicos da esporulaçă năo é conservada nos zoósporos maduros; o zoosporos contém mRNAs armazenados que provavelmente sa sintetizados nos últimos 30 minutos da esporulaçăo.

Durante a transiģa dos zoósporos a células redondas, que ocorre nos primeiros 25 minutos após a induggo da germinaçăo em meio inorgânico, năo foram verificadas diferenças qualitativas no padrăo de síntese proteica, tanto 
na auséncia como na presenca de actinomicina $D$, indicando que os eventos precoces da germinacro so inteiramente préprogramados pelo mRNA que está armazenado nos zósporos. Contudo, na germinacro tardia sao verificadas profundas variaças no padryo de sintese proteica. A sintese de algumas dessas proteinas (seis polipeptidios), provavelmente corresponde a uma traduça seletiva de mensagens armazenadas nos zoosporos, enquanto que a maioria das novas proteinas expressas (vinte e dois polipeptidios) corresponde a traduçăo de novos mRNAs. Assim, durante a germinaça dos zoósporos, ocorrem múltiplos niveis de regulaça da síntese proteica, envolvendo controles ao nivel da traduçăo e transcriçăo. Durante o inicio da germinaça também foi observado um controle ao nível de pós-traduçăo, com várias proteinas dos zoósporos sendo especificamente degradadas ou modificadas. Também analisamos o padra das proteínas sintetizadas durante a germinaça em meio nutriente sendo observada a sintese de polipeptidios especificos desta condiçăo de germinaçăo e crescimento.

Algumas proteinas cuja sintese é controlada pelo desenvolvimento foram identificadas. Utilizando anticorpos monoclonais comerciais contra actina, a e $\beta$-tubulinas foi possivel identificar estas proteinas no perfil eletroforético de proteínas sintetizadas durante a esporulaçao. Comparando a cinética da síntese "in vivo" destas proteinas com o acúmulo de seus respectivos mRNAs traduzidos "in vitro", foi possível demonstrar que o intenso 
aumento na sintese de actina, a e B-tubulinas que ocorre durante a esporulaço apresenta uma correlacgo temporal com - aumento dos mRNAs correspondentes. Em paralelo ao aumento da sintese destas tres proteinas citoesqueléticas póde ser detectado um aumento dos seus conteúdos em massa. Durante a germinaçăo crescimento ocorre uma sensível diminuigaro no conteúdo destas proteinas. Além disso, verificamos que as proteinas identificadas como $\alpha$ e $\beta$-tubulinas estao presentes no flagelo dos zoósporos.

Muito interessante foi a observaço de que trés proteinas sintetizadas durante a esporulaço correspondiam aparentemente a tres proteínas, Hsp70, Hsp76 e Hsp39a, Cuja síntese é induzida pelo choque térmico. Esta verificafăo decorreu do fato de estarmos investigando se em Blastocladiella a resposta ao choque térmico teria algum controle do desenvolvimento, uma vez que alguns dados da Literatura sugeriam o envolvimento de certas proteinas de choque térmico (Hsps) no desenvolvimento normal de alguns organismos.

Em Blastocladiella a resposta ao choque térmico é dependente do estágio do desenvolvimento. Células expostas a temperaturas elevadas nos diferentes estagios do desenvolvimento (esporulaçăo, germinaça e crescimento) mostram uma sintese diferencial de proteinas de choque térmico. Conjuntos especificas de Hsps (de um total de 22 Hsps) são induzidos em cada fase, demonstrando uma expressăo năo coordenada dos genes de choque térmico. 
A proteina de $70 \mathrm{kDa}$, sintetizada espontaneamente durante um certo intervalo da esporulaça, apresenta mobilidade eletroforetica em géis bidimensionais identica a Hsp70. A confirmaça da identidade entre estas proteinas foi obtida através de análise dos seus peptidios resultantes de digestao enzimatica parcial bem como pelo reconhecimento de ambas as proteínas por anticorpos contra a proteína Dnak (homóloga a Hsp70) de E. Coli e contra a proteína Hsp70 de Drosophila. Utilizando traducăo "in vitro" de RNA e hibridizagao de RNA com uma sonda do gene hsp70 de Drosophila, demonstramos que o aumento de sintese da Hsp70 que ocorre durante o choque térmico e espontaneamente durante a esporulaça, está associado com a acumulaça do mRNA desta proteína.

Embora a sintese de Hsps seja controlada pelo desenvolvimento em Blastocladiella, a aquisifgo de termotolerância pode ser induzida em qualquer estágio do seu ciclo de vida. $A$ induça da termotolerância em Elastocladiella é dependente da síntese de proteinas e esta correlacionada com o aumento da síntese de algumas Hsps: Hsp82a, Hsp82b, Hsp76, Hsp70, Hsp60,Hsp25 e Hsp17b. Hs outras Hsps parecem naro estar envolvidas especificamente com a termotolerância .

As observaçoes anteriores de que o estado de fosforilaça da proteína ribossômica 56, em Blastocladiella, varia durante o desenvolvimento e em resposta a alteraços do meio ambiente (Bonato et al., 1984, Eur. J. Biochem. 144: 
597-606) a verificacro de que a resposta a choque térmico, em Blastocladiella, também está sob o controle do desenvolvimento proporcionou a oportunidade de verificar se os diferentes niveis de fosforilacgo de 56 poderiam ser correlacionados com a traducgo de mensageiros especificos istoé, mRNAs normais ou de choque térmico - durante o choque térmico, recuperagro do choque térmico e induça de termotolerancia nos diferentes estágios do ciclo de vida deste fungo. Assim foi observado que, independente do estado inicial de fosforilaggo de 56 (máximo ou intermediário), ocorre uma rápida e completa desfosforilaggo de 56 durante o choque térmico, sendo que a 56 permanece desfosforilada durante a termotolerancia. Durante a recuperaça do choque térmico, ocorre a refosforilaço de 56 para os níveis caracteristicos de cada estágio do desenvolvimento, coincidentemente com a interrupço da sintese de proteinas de choque térmico. 
SUMMARY

Using lasofmethionine pulse labeling, in vitro translation and two-dimensional gel electrophoresis, we investigated the regulation of protein synthesis during two distinct phases of cell differentiation, sporulation and germination, in the aquatic fungus Blastocladiella emersonii.

We have found dramatic changes in the spectrum of proteins synthesized during sporulation. Synthesis of 108 polypeptides was analyzed and a large increase in the synthesis of several proteins is associated with particular stages. A large number of basic proteins are synthesized exclusively during late sporulation. Changes in translatable mRNA species were also detected by in vitro translation of RNA prepared at different stages of sporulation. The synthesis of several proteins during sporulation seems to be transcriptionally controlled. Mast of the sporulationspecific messages are not present in the mature zoospores; the zoospores contain stored mRNA, which is apparently synthesized in the last $30 \mathrm{~min}$ of sporulation.

We analyzed the pattern of proteins synthesized during zoospore germination in an inorganic solution, in both the presence and absence of actinomycin D. During the transition from zoospore to round cells (the first $25 \mathrm{~min}$ ), essentially no qualitative differences were noticeable, indicating that the earliest stages of germination are entirely preprogrammed with stored RNA. Later in germination (after 
25 min), however, changes in the pattern of protein synthesis were found. Some of these proteins (a total of 6 polypeptides) correspond possibly to a selective translation of stored messages, whereas the majority of the changed proteins ( 22 polypeptides) corresponds to newly synthesized mRNA. Thus, multiple levels of protein synthesis regulation seem to occur during zoospore germination, involving both transcriptional and translational controls. We also analyzed the pattern of protein synthesis during germination in a nutrient medium; synthesis of specific polypeptides occurred during late germination. During early germination posttranslational control was also observed, several labeled proteins from zoospores being specifically degraded or charge modified.

Some proteins whose expression is developmentally regulated were identified. Actin, $\alpha$ - and $\beta$-tubulin have been identified in the two-dimensional pattern of proteins synthesized during sporulation by using well characterized monoclonal antibodies and western blotting. We compared the kinetics of synthesis of these proteins, by pulse-labeling experiments with jos/methionine, with the accumulation of their corresponding mRNAs, translated in a cell-free system. Large increases occur in the rates of actin and $a$ - and B-tubulin biosynthesis during sporulation and there is an accumulation of the corresponding mRNAs. In parallel to the increased synthesis, these cytoskeletal proteins accumulate during the late stage of sporulation. During germination and 
early growth there is a strong decrease in the level of these proteins. We also verified that $\alpha$ - and $\beta$-tubulin are present in flagellar axonemes of zoopores.

Very interesting was the observation that three proteins spontaneously expressed during sporulation correspond possibly to three heat shock-induced proteins (Hsp70, Hsp76, Hsp39a). This fact was noticed when we were investigating the heat shock-response during the development of Blastocladiella.

The heat-shock response in Blastocladiella is dependent on the developmental stage. Cells exposed to elevated temperatures at different stages of life cycle (sporulation, germination or growth) show a differential synthesis of heat-shock proteins (Hsps). Of a total of 22 polypeptides induced, particular subsets of Hsps appear in each phase, demonstrating a non-coordinate heat-shock gene expression.

By the criteria of two-dimensional gel electrophoresis and partial proteolysis mapping, the 70-kDa protein, whose synthesis is induced spontaneously during sporulation, is indistinguishable from the heat-inducible hsp70. Additional evidence in support of the identity between the 70-kDa protein and Hsp70 was provided by immunological crossreaction of both proteins with antibodies against Dnak protein from E.coli and Hsp70 from Drosophila. The techniques of in vitro translation, and Northern analysis using a Drosophila hsp70 probe, demonstrated that enhanced synthesis of hsp 70 , which occurs during heat-shock treatment 
10.

and spontaneously during sporulation, is associated with an accumulation of Hsp70 mRNA.

Although the Hsps synthesis is developmentally regulated in Blastocladiella, the acquisition of thermotolerance can be induced at any stage of the Life cycle. The development of thermotolerance is correlated with the enhanced synthesis of some heat-shock proteins: Hsp82a, Hsp82b, Hsp76, Hsp70, Hsp60, Hsp25, Hsp17b. Dther Hsps are not specifically involved in thermotolerance.

In B. emersonii the state of 56 phosphorylation changes depending on the developmental stage and environmental conditions (Bonato et al., 1984, Eur. J. Biochem. 144, 597606). On the other hand, we verified that the heat-shock response is developmentally regulated. Then, we examined the changes in 56 phosphorylation during heat shock, thermotolerance, and recovery from heat shock at different stages of life cycle in order to investigate whether the different levels of 56 phosphorylation might be correlated with the translation of specific message subsets. We observed that independently of the initial state of 56 phosphorylation (maximal or intermediate), a rapid and complete dephosphorylation of 56 is induced by heat shock and 56 remains unphosphorylated during the acquired thermotolerance. During recovery from heat shock rephosphorylation of 56 occurs always to the levels characteristic of that particular stage, coincidently with the turn off of heat shock protein synthesis. 


\section{INTRODUட̧AD}

Diferenciação celular é uma capacidade inerente a praticamente todas as formas de vida compreendendo desde a simples formaça de estruturas subcelulares como flagelo e pili de bactérias até o desenvolvimento de um arganismo pluricelular a partir da célula-ovo. 0 conceito de diferenciaça celular implica na existência de um programa genético que envolve a expressao ordenada e seletiva de certos genes e o modo pelo qual os produtos destes genes agem para produzir uma célula com um fenótipo especializado. Flutuações no meio extracelular, que incluem desde sinais químicos transmitidos pelas células até mudanças abruptas nos nutrientes disponiveis, podem também interferir nesse programa de desenvolvimento ou mesmo desencadeálo. Uma questro fundamental na biologia do desenvolvimento é a compreensao dos mecanismos de controle que levam à coordenação temporal da expressă dos genes envolvidos neste evento. Na maioria dos sistemas biológicos estudados este controle é exercido predominantemente a nivel de transcriça diferencial dos genes.

Durante a esporulaçăo em Bacillus subtilis să sintetizadas proteínas especificas numa sequência rigorosamente programada, que é aparentemente controlada por uma cascata de diferentes subunidades (fatores sigma) da RNA-polimerase que aparecem em certos momentos da esporulaçăo e que săo capazes de redirecionar a 
especificidade da holoenzima para diferentes promotores gênicos (Losick e Youngman, 1984). Transcriçăo diferencial também parece ser o principal mecanismo que regula o acúmulo de mRNAs induzidos pelo desenvolvimento em Dictyostelium discoideum (Chisholm et al., 1984), durante a formaçăo de conidios em Neurospora crassa (Berlin e Yanofski, 1985a) e durante a esporulaçăo em Saccharomyces cerevisiae (WeirThomps.0n e Dawes, 1984; Kurtz e Lindquist, 1984).

Dutros níveis de controle também parecem ser importantes na regulação da expressão gênica durante o desenvolvimento. Algumas evidências sugerem que a estabilidade diferencial de mRNAs é responsável pela determinaça dos niveis citoplasmáticos dos mensageiros específicos de certos estágios do desenvolvimento em D.discoideum (Mangiarotti et al.,1982; Kelly et al., 1985). Este tipo de regulaçao ocorre durante a expressăo diferencial de genes de fotosintese em Rhodopseudomonas capsulata (Belasco et al.,1985). Durante a formação do corpo de frutificą̧a de Mixococcus xanthus, uma fraça da populaçăo de mRNAs possui uma vida-média relativamente Longa, enquanto outras fraçăes decaem rapidamente C $N$ elson e Zusman, 1983). Também nos estágios tardios da miogênese e da eritropoiese, certos mRNAs como o da miosina e da globina să preferencialmente mais estáveis (Affara et al., 1980; Volloch e Housman, 1981).

Na fertilizaçăo de ácitos de ouriço do mar o aumento na sintese proteica parece ser regulado ao nível da 
disponibilidade de mRNAs maternais para a traducgo e também ao nivel da atividade dos componentes da maquinaria de traduçăo (Winkler et al., 1985). Contudo este aumento da síntese proteica ngo é acompantido por uma variaçao significativa no padra das proteínas sintetizadas durante a fertilizaça (Brandhorst, 1976). Por outro lado, as alteraçós no padra de síntese proteica verificadas apos a fertilizaça de oócitos de Spisula solidissima ou durante a maturação de oócitos de estrela-do-mar săo, também, devidas a utilizaça estágio-específica de diferentes populaçóses de mRNA maternal (Rosenthal et al., 1980; Rosenthal et al., 1982). Um dos exemplos mais interessantes de regulação ao nivel da traduça seletiva foi recentemente verificado durante a citodiferenciaçăo induzida pela luz em Volvox. 0 padra de sintese proteica varia rapidamente apos a iluminaçăo das células, sendo que actinomicina $\square$ nao exerce nenhum efeito nesta variaça e os RNAs isolados de células năo-iluminadas e iluminadas fornecem idênticos produtos de traduço "in vitro" (Kirk e Kirk, 1985).

Processamento de RNA também pode estar envolvido no controle do desenvolvimento (Leff et al., 1986). Além dis5o, rearranjos no DNA parecem ocorrer em diversos sistemas, levando a importantes consequencias fenotipicas. Ds exemplos melhor caracterizados de rearranjos gênicos durante o desenvolvimento envolvem os genes das imunoglobulinas de vertebrados (Hood et al., 1985) e os genes que determinam o tipo de acasalamento em levedura (Klar et al., 1984). 
Rearranjos nos genes de fixaço de nitrogénio ocorrem durante a diferenciaça celular dos heterocistos de Anabaena induzida pela caréncia de nitrato e amónia cGolden et al., 1985).

E também importante destacar a ocorréncia de certas modificaças nas proteinas ao nivel de pós-traduça durante a morfogenese e diferenciaçăo celular. Muitas das variaçốes qualitativas abservadas nos padras de síntese proteica durante o início do desenvolvimento em camundongos săo devidas a modificações pós-traducionais de proteinas (Blerkom, 1981).

Todavia, ainda muito pouco é conhecido acerca de como os genes envolvidos no processo de diferenciagro săo regulados, quais genes estao envolvidos e que funço exercem os produtas destes genes. Esforços tem sido realizados no sentido de identificar proteínas cuja expressao elou atividade sofra a interferência do processo de diferenciaça celular.

Em vários sistemas experimentais tem sido demonstrado que variaçães no formato celular e na organizaçăo citoplasmática 5 ăo importantes na regulaçăo da expressăo de genes relacionados com o crescimento e diferenciaçăo celular. o envolvimento do citoesqueleto no controle do crescimento e da diferenciaçăo sugere, portanto, a possibilidade de que tais mecanismos de controle possam depender diretamente da expressao de genes para as proteínas citoesqueléticas. Esta noçăo foi inspirada na abservaçăo de 
que alteraçäes no formato celular bem como nos padroes de contato celular podem afetar a expressao de elementos do citoesqueleto, provavelmente por um mecanismo de regulaçăo pelo produto final (Ben-Ze'ev, 1986; Farmer, 1986). Como exemplo pode ser citada a verificagro de que a despolimerizaçăo de microtúbulos inibe especificamente a expressaro do mRNA para tubulina, acelerando o seu decaimento (Ben-Ze'ev et al., 1979; Cleveland et al., 1981). Além disso, algumas evidencias mostram que o gene da actina naromuscular, que inicialmente era considerado um gene do tipo "housekeeping", isto é, expresso constitutivamente para formar a rede de microfilamentos citoesqueléticos, na verdade năo é expresso constitutivamente, mas sim sob um rigoroso controle, além de exercer um papel regulatório no crescimento e na diferenciaçăo (Farmer, 1986). Por exemplo, em D.discoideum, a actina é uma proteina abundante e a sua sintese é regulada durante a formaça do corpo de frutificação e também durante a germinação do esporo (Kimmel e Firtel.,1982).

Actina e tubulina esta entre as proteinas mais importantes do sistema citoesquelético da maioria das células eucarióticas. Estas proteínas estão envolvidas em vários processos biológicos como mudanças no formato celular, crescimento, motilidade, secreça, divisăo diferenciaçăo (Cleveland e Sullivan, 1985; Farmer, 1986), embora pouco se contieça como elas estao organizadas ou como elas exercem suas funções celulares na maioria dos 
organismos. Actina e tubulina sao considerados polipeptidios altamente conservados. [ontudo, foram verificadas várias diferencas nas propriedades imunologicas e bioquimicas entre as tubulinas de animais, plantas e eucariotos inferiores (Moregohn e Fosket, 1986). Além disso, tem sido encontrada uma heterogeneidade de formas de actina e tubulina gerada por eventos de modificaça pós-traduçăo ou pela existência de familias multigênicas para estas proteinas c Jantzen, 1981; Kimmel e Firtel, 1982; Cleveland e Sullivan, 1985). Também foi verificada uma distribuiçăo especifica de certas isoformas em algumas organelas, tais como os flagelos (Russell et al., 1984; 5asse et al., 1987; Diggins e Dove, 1987). As modificaçôes ao nível de pós-traduçăo que originam a heterogeneidade da tubulina, parecem estar sob um rigoroso controle do desenvolvimento e da morfogênese cleveland e Sullivan, 1985).

Em adiçăo às variaçơes na atividade gênica que ocorrem durante o processo de diferenciaça celular característico dos vários organismos vivos soma-se a capacidade destes organismos responderem a variações do meio ambiente, através da ativaçăo elou desativaça transitória de um conjunto específico de genes. Quando estas alteraçôs se constituem em uma agressão, como por exemplo altas temperaturas, as células, dos mais diversos seres vivos, reagem de forma semelhante, apresentando modificações no seu padrăo de transcriçăo gênica e de sintese de proteínas, modificaçơs 
essas conhecidas, genericamente, como resposta ao choque térmico.

A resposta ao choque térmico - Em resposta a uma súbita elevaça da temperatura, praticamente todos os organismos até agora estudados, da bactéria ao homem, sintetizam um conjunto de proteínas denominadas proteinas de choque térmico (Hsps, do inglês "heat shock proteins"). Este fenômeno é conhecido como resposta ao choque térmico. No entanto, a exposição das células a vários outros agentes agressores, como etanol, metais pesados, análogos de aminobcidos, inibidores da fosforilaçăo oxidativa, anóxia, arsenito de sódio, dentre outros, levam a induçáo de uma resposta similar tanto em procariotos como eucariotos (para reviså, ver Schlesinger et al., 1982a,b; Atkinson e Walden, 1985; Lindquist, 1986).

Este fenómeno tem sido bastante estudado em Drosophila, onde foi primeiramente observado, há vinte e cinco anos atrás, por Ritossa (1962). A observaçăo, ao microscópio, dos cromossomos politênicos de glândulas salivares, após elevaçăo da temperatura de 20 para $37^{\circ}[$ ou após tratamento com dinitrofenol, demonstrau o aparecimento de vários novos pufes. A induçăo de um conjunto de proteínas após choque térmico foi demonstrada somente dez anos mais tarde (Tissieres et al., 1974) e durante os anos que se seguiram foi esclarecido que os pufes eram sitios onde ocorria vigorosa transcriçăo de RNA e que vários destes RNAs eram 
traduzidos nas protelnas de choque térmico. Inicialmente se pensou que esta induçáo seletiva de proteínas era uma propriedade exclusiva de Drosophila. Contudo por valta de 1978-1979, uma resposta análoga foi verificada em cuttura de células de mamíferos e aves (Kelley e Schlesinger, 1978), E.coli (Lemeaux et al., 1978; Yamamori et al., 1978), Tetrahymena (Fink e Zeuthen, 1978) e em Levedura (McAlister et al., 1979). Inúmeros trabalhos se seguiram, relatando respostas similares em uma extraordinária variedade de organismos. A ubiqüidade da resposta ao choque térmico e a extrema conservaçăo de alguns dos genes de Hsps ao longo da evoluçăo, não apenas nas suas sequências codificadoras mas também nas suas sequências regulatórias, atestam a importancia das Hsps (Schlesinger et al., 1982a; Schlesinger, 1986).

As sete principais proteinas induzidas pelo choque térmico em D. melanogaster săo designadas Hsp83, Hsp70, Hsp68, Hsp27, Hsp26, Hsp23 e Hsp22. Estas proteínas foram nomeadas de acordo com seu peso molecular aparente em géis de poliacrilamida/SDS. Embora o número exato de Hsps varie nos diferentes organismos, a maioria delas corresponde a polipeptidios predominantemente nas faixas de peso molecular de 80 a $90 \mathrm{kDa}, 68$ a $74 \mathrm{kDa}$ e 18 a $30 \mathrm{kDa}$. Estas três classes de Hsps săo extremamente conservadas (Craig, 1985). Anticorpos contra a Hsp70 e Hsp89 de fibroblastos de embria de galinha apresentam reaça cruzada com proteínas equivalentes de varios organismos (Kelley e Schlesinger, 
1982). Além disso, foi observada hibridizaça cruzada entre - gene hsp70 de Drosophila com sequéncias genomicas de diferentes organismos (Ingolia et al., 1982; Bardwell e [raig, 1984). Os peptídios resultantes da digestao tríptica da Hsp 83 de Drosophila comigram em cromatografia de camada delgada com os peptidios equivalentes de proteinas de células de galinha (Hsp89) a humanas (Hsp90), sugerindo uma estreita similaridade entre estas três proteinas cVoellmy et al., 1983). Embora as Hsps de menor peso molecular de um dado organismo mostrem uma homologia maior entre si mesmas do que com retaça as estas proteínas em outras espécies, a análise da sequência de seus genes demonstrou uma certa homologia entre as Hsps menores de insetas, vertebrados e nematódeos além de uma homologia parcial com a cadeia acristalino de mamíferos (Ingolia e Craig, 1982a; Russnak et a (. , 1983; Bienz, 1984).

Mas, é a Hsp70 a mais conservada das Hsps. Por exemplo, as proteínas Hsp70 de Drosophila e levedura apresentam uma homologia de $72 \%$ em termos das suas sequéncias de aminoácidos (Ingolia et al., 1982). A sequência desta proteína deduzida a partir do gene hsp70 humano mostra uma homologia de 73\% à Hsp70 de Drosophila (Hunt e Morimoto, 1985). Além disso, o produto do gene dnak, uma proteína abundante induzida também pelo choque térmico em E.colí, possui 50\% de homologia com a Hsp70 de Drosophila, e uma similaridade antigênica com as Hsps70 de levedura, galinha e 
homem, sendo talvez um dos elementos mais conservados na evoluçå (Neidhardt et al., 1984).

[omo demonstrado por Bardwell e Craig (1984), o gene dnak é único, mas em Drosophila e 5 . cerevisiae, os genes hsp70 compõem uma família multigênica, cujos membros respondem à temperatura de diferentes maneiras (Ingolia e [raig, 1982b; Wadsworth, 1982; Ingolia et al., 1982). Na maioria dos eucariotos até agora examinados, os genes que codificam para os polipeptidios de $70 \mathrm{kDa}$ indutiveis pelo calor são membros de famílias multigênicas. Estas famílias também incluem genes cognatos que codificam para proteínas de aproximadamente o mesmo peso molecular, constitutivamente expressas, porém nåo indutíveis pelo calor (Craig et al., 1983; Lowe e Moran, 1984; D'Malley et al., 1985). Um anticorpo monoclonal produzido contra a Hsp70 de Drosophila reage com um grupo de proteínas de aproximadamente $70 \mathrm{kDa}$ em Drosophila, ouriço do mar, nematódeo, células de galinha e humanas. Algumas destas proteínas 5 a induzidas pelo calor, porém outras não ( 5 . Lindquist, resultados nåo publicados, (f. Lindquist, 1986).

Em E. coli, o produto do gene dnak, homólogo à Hsp70 e que é expresso mesmo à temperatura normal, foi originalmente identificado como uma proteína necessária para a replicaçăo do bacteriófago lambda. A sua sintese é aumentada após a transferencia das células para temperaturas mais altas, porém a sua funçăo, em células năo-infectadas, ainda nåo foi 
encontrada, embora ela seja essencial para o crescimento celular (Neidhardt et al., 1984).

A proteína Hsp70 apresenta uma mobilidade na célula, indo do citoplasma para o núcleo apos o tratamento térmico e retornando ao citoplasma durante a recuperaço das células; no núcleo, a Hsp70 se concentra no nucléolo (Pelham, 1984; Welch e Suhan, 1985; Collier e Schlesinger, 1986). A Hsp70 passa da forma citosolica solúvel para uma fraça do citoesqueleto nuclear após o choque térmico e sua forma insolúvel é solubilizada numa reaça dependente de ATP (Lewis e Pelham, 1985). Aliás, as Hsps70 de mamíferos ligam fortemente ATP, uma propriedade que tem sido explorada para sua purificaçăo (Welch e Feramisco, 1985). Recentemente Chappell et al. (1986) apresentaram fortes evidencias (purificaçăo por afinidade em colunas de ATP-agarose, mapa peptidico, análise em eletroforese bidimensional e reatividade antigenica cruzada) que uma ATPase que remove clatrina de vesiculas cobertas, e que é sintetizada constitutivamente em células de mamíferos, é um membro da familia das Hsplo.

As propriedades das outras Hsps năo estao ainda bem esclarecidas, porém, algumas evidências sugerem que a Hsp90 poderia reconhecer sítios hidrofóbicos de proteinas desnaturadas após o tratamento térmico, ligando-se a elas e prevenindo assim a formaça de precipitados insolúveis e danosos à célula (Pelham, 1985). Recentemente foi observado que o gene da ubiqüitina é ativado pelo choque térmico tanto 
em fibroblastos de embriaro de galinha como em leveduras (Bond e Schlesinger, 1985; A. Findley e A. Varshavsky, resultados nå publicados, cf. Lindquist, 1986). A associação entre choque térmico e proteases é também encontrada em procariotos; um dos genes de E. coli regulados pelo choque térmico é lon, que codifica para uma protease dependente de ATP (Phillips et al., 1984). Assim, atualmente especula-se que essas atividades proteoliticas fariam parte do sistema celular que percebe o estresse causado pelo choque térmico (Munro e Pelham, 1985; Schlesinger, 1986).

A resposta ao choque térmico é frequentemente vista como uma função de sobrevivência celular, capaz de proteger os organismos contra os efeitos tóxicos do calor ou de outros agentes. Contudo, a exata funçăo das Hsps ainda é obscura. Uma observação interessante é o fato da induça de proteinas de choque térmico coincidir com a aquisiça de tolerancia a temperaturas mais extremas em diversos organismos ( Craig, 1985).

O fenômeno da termotolerancia é definido como uma capacidade indutivel das células, que se caracteriza pelo fato das células adquirirem resistencia a temperaturas elevadas (letais), desde que tenham sido anteriormente expostas ao choque térmico ou a outros estresses. A préexposiça ao choque térmico ou a temperaturas intermediárias parece proteger as células da morte que poderia ser provocada por um estresse subsequente mais severo (Gerner e Schneider, 1975; MCAlister e Finkelstein, 1980a; Loomis e 
Weeler, 1980; Plesset et al., 1982; Li, 1983; Plesofski-Vig e Brambl, 1985).

A idéia de que proteinas indutiveis seriam responsáveis pelo aumento da termorresistência surgiu a partir dos resultados de experimentos, utilizando cicloeximida, em Dictyostelium e levedura, que indicavam a necessidade de sintese proteica durante a incubaça a temperaturas intermediárias, para a aquisiça da termorresistência (Loomis e Weeler, 1980; McAlister e Finkelstein, 1980a). Além disso, outros agentes que induzem Hsps também conferem termotolerância C $L$ e Werb, 1982; Hahn e Li, 1982; Yamamori e Yura, 1982; Li, 1983). Somam-se a estas evidências de um envolvimento das Hsps na aquisiça de termotolerancia, o fato de que o decaimento da termotolerância coincide com a degradaçro das Hsps ( $L i$ e Laszlo, 1985) e também relatos de que em certos estágios do desenvolvimento nos quais as Hsps ngo podem ser induzidas, os organismos sao extremamente mais sensiveis ao calor e não adquirem termotolerância (Lindquist, 1986).

Contudo, alguns dados da literatura indicam que nem todas as Hsps estão necessariamente envolvidas na termoproteção. Alguns autores relataram a importancia das Hsps de menor peso molecular (Loomis e Weeler, 1982; Berger e Woodward, 1983), ainda que, embrioes de Drosophila que sintetizam constitutivamente as Hsps de menor peso molecular sejam extremamente termossensíveis (Zimmerman et al., 1983). Também existem evidencias de que nenhuma sintese de Hsps 
parece ser necessária para a induça da termotolerância adquirida em levedura e em fibroblastos de rato (Hall, 1983; Widelitz et al., 1986).

Ao lado de um papel na resposta ao estresse, as Hsps poderiam desempenhar uma funço importante no desenvolvimento normal dos organismos. Esta hipótese é baseada na observaça de que alguns genes de choque térmico săo ativos durante certos estágios do desenvolvimento ou em certos tipos celulares em condiçoses fisiológicas normais (Bienz, 1985). Durante a oogênese e o estágio de pré-pupa, em Drosophila, sao expressos alguns genes hsp (Zimmerman et al., 1983; Mason et al., 1984). Em embriogs de camundongo, a ativaça do genoma ocorre no estágio de duas células e resulta em uma intensa variaça no padra de proteínas sintetizadas; entre as proteinas especificas desta fase estão proteínas idênticas a Hsp68 e a Hsp70 (Bensaude et al., 1983). Células de carcinoma embrional de camundongo também expressam altos niveis de Hsps na ausencia de estresse (Bensaude e Morange, 1983). Durante a esporulação em levedura ocorre a sintese de RNA para duas possiveis Hsps (26 e 84) (Kurtz e Lindquist, 1984).

Por outro lado, em certos estágios do desenvolvimento ocorre uma repressão da expressao de genes de certas Hsps mesmo durante o tratamento térmico. Em oócitos de Xenopus o mRNA para Hsp30 năo é detectado mesmo após a choque térmico, contudo sua indutibilidade pelo calor é restaurada no estágio de girino (Bienz, 1984). Reticulócitos de galinha 
respondem ao calor com a induça de apenas uma Hsp (Hsp7O), enquanto os linfócitos induzem a sintese de Hsp70, Hsp89, Hsp23 e Hsp 22 (Morimoto e Fodor, 1984). Também durante a oogênese em Drosophila, a hipertermia nă induz alguns genes de choque térmico (hsp70, hsp68, hsp22 e hsp23) (Zimmerman et a $(., 1983)$.

Um aspecto interessante da expressa dos genes de choque térmico é que os níveis de sua regulaçăo, nos diferentes organismos e mesmo nos diferentes tipos celulares de um mesmo organismo, podem ser diferentes. Em E. coli e levedura a resposta é controlada primariamente ao nivel da transcriça (Yamamori e Yura, 1982; Mchlister e Finkelstein, 1980b). Em Drosophila a regulaçăo é exercida tanto ao nível da transcriçăo como da traduçăo (Lindquist e DiDomenico, 1985). Em Xenopus, a resposta das células somáticas é controlada primariamente ao nivel da transcriça e a resposta de ócitos é regulada ao nível da traduçăo (Bienz e Gurdon, 1982).

Todavia, um mecanismo comum parece regular a transerigaro de todos as genes eucarióticos de choque térmico durante a hipertermia. Pelham (1982) identificou uma pequena sequência regulatória na regiăo 5' a montante do gene hsplo de Drosophila que é essencial para transcricaro deste gene quando em células de macaco submetidas à hipertermia. Esta sequência está localizada a mais ou menos 20 pares de bases a montante da "TATA box". A comparaça com os promotores de outros genes de choque térmico em Drosophila revelou a 
existência de uma sequencia consenso minima, rotacionalmente simétrica, C--GAA--TTE--G, denominada HSE (do inglés, "Heat Shock Element"). Sequências similares foram encontradas adjacentes a genes de choque térmico de outros organismos, o que explica a ativaça pelo calor dos genes de Drosophila quando introduzidos em células heterólogas (Pelham, 1985).

Aparentemente estas regiŏes HSE săo reconhecidas por um fator de transeriçăo de choque térmico (HSTF, do inglês "Heat Shock Transcription Factor") recentemente purificado e caracterizado pela propriedade de ligar-se a HSE "in vivo" e "in vitro" (Parker e Topol, 1984; Wu, 1984). O HSTF pode ser isolado tanto de células submetidas a tratamento térmico como de células controle, sendo, contudo, mais ativo quando isolado de células aquecidas (Parker e Topol, 1984). Este fato sugere que o HSTF existiria normalmente sob forma inativa e somente seria ativado mediante hipertermia ou outros tipos de agressão, ligando-se de maneira cooperativa às várias regiões HSE existentes nos promotores dos genes de choque térmico (Topol et al., 1985; Burdon, 1986).

A induça da sintese das proteinas de choque térmico, na maioria dos organismos, é devida a um aumento da transcrição de genes eucarióticos de choque térmico além da tradução seletiva destes mRNAs. Em Drosophila, a choque térmico ativa algum mecanismo de controle a nível da traduçăo que promove a traduça de mRNAs de Hsps e reprime especificamente a traduçăo dos mRNAs normais pré-existentes (Lindquist, 1980, 1981). Contudo os mRNAs pré-existentes 
permanecem estácis e traduzíveis em outros sistemas "in vitro", ou "in vivo" apos a recuperaçao do choque térmico (Krüger e Benecke, 1981; 5torti et al., 1980). Lisados preparados a partir de celulas de D.melanogaster que sofreram choque térmico podem traduzir apenas mRNAs para as Hsps, porém a adiçăo de uma preparaça ribossomal de células controle a estes lisados, restaura a capacidade destes lisados traduzirem os mRNAs normais além dos de choque térmico (Scott e Pardue, 1981), sugerindo que a capacidade das células, submetidas ao tratamento térmico, de discriminarem entre mRNAs normais e de choque térmico poderia estar nos ribossomos. Entre outros fatores, tem sido muito discutido um possivel envolvimento da proteína ribossomal 56 na mudança da especificidade da maquinaria de traduçăo durante o choque térmico.

A fosforilaça da proteína ribossomal 56 - Após a observação de Loeb e Blat (1970) e Kabat (1970), que ribossomos de células de mamíferos possuíam proteínas fosforiladas, um grande numero de estudos foram realizados na tentativa de elucidar o papel de tal fosforilaça.

Ds resultados acumulados ao longo de mais de dez anos demonstraram que uma proteína básica da subunidade 405. denominada 56, com peso molecular entre $30-35 \mathrm{kDa}$, é a principal fosfoproteína ribossomal, nos vários eucariotos examinados. A 56 pode estar fosforilada em múltiplos sftios "in vivo" e a extensă desta fosforilaça pode ser 
modificada por diferentes estímulos, tanto fisiologicos como patológicos (para revisaro, ver Leader, 1980 e Gordon et al., 1982).

Uma correlaçăo entre o aumento da fosforilaçăo de 56 e a estimulaça da sintese proteica, tem sido proposta por vários autores, pois muitos agentes que promovem crescimento e proliferaçao celular estimulam a fosforilaça de 56 . Em culturas de células de mamíferos, quiescentes ou em ausencia de soro, a fosforilaçăo de 56 é estimulada por insulina, prostaglandina, ester de forbol, soro, fatores de crescimento e transformaça viral (Thomas et al., 1982; Trevillyan et al., 1985; Blenis et al., 1984). Em oócitos de Xenopus, a fosforilação de 56 é estimulada em resposta a progesterona, aumento do pH e após injeção de uma tirosinaquinase de origem viral (Maller et al., 1985). A fertilizaçăo de oócitos de ouriço do mar e a germinação de esporos de Mucar racemosus são acompanhadas de um aumento na fosforilação de 56 (Ballinger e Hunt, 1981; Larsen e Sypherd, 1980). Além dis50, algumas evidências associam a desfosforilação de 56 com situações onde a sintese proteica, ou a quantidade de polissomos, estádiminuida, como durante - tratamento hipertonico de células em cultura ckruppa e [lemens, 1984) ou durante o choque térmico em Drosophila e plantas (Glover, 1982; Scharf e Nover, 1982).

Contudo, vários trabalhos relatam que a fosforilaça de 56 pode ser estimulada em condiçós onde a sintese proteica está aumentada, inibida ou inalterada (Traugh, 1981). No 
protozoario Tetrahymena, a fosforilaça de 56 é estimulada pela carencia nutricional, situaço onde a síntese proteica está dimuinuida (Hallberg et al., 1981). Em Dictyostelium discoideum também se observa a fosforilaçăo de 56 em condiços de carência. Contudo, esta fosforilaço está aparentemente relacionada com o processo de agregaça celular, que é induzido pela carência, uma vez que naro se observou a fosforilaça de 56 em mutantes que năo agregam (Juliani et al., 1983). No fungo Blastocladiella emersonii. - estado de fosforilação de 56 varia durante o ciclo de vida; contudo durante a esporulas̆o induzida pela caréncia nutritiva o estado de fosforilaça de 56 não é alterado; a 56 apresenta-se em um estado intermediário de fosforilaçao ao longo de toda a esporulaça. Além disso a estimulaçăo da sintese proteica que ocorre durante a germinaça dos zoósporos e que é dirigida essencialmente pelo mRNA préexistente armazenado nos zoósporos, ngo é dependente dos derivados de 56 maximamente fosforilados, embora sob certas condições de germinaçao, por exemplo, presença de extrato de levedura, seja verificada máxima fosforilaça de 56 (Bonato et al., 1984).

Várias preparaçōes de proteína quinase, as quais foram purificadas de acordo com suas capacidades para fosforilar vários substratos, foram descritas como capazes de fosforilar, ainda que em diferentes niveis, a proteina 56 "in vitro" (Traugh e Pendergast, 1986). Qual destas enzimas é responsável pela fosforilação de 56 "in vivo", em resposta 
aos vários estímulos, ainda nao estáclaro. Algumas especulaços for am feitas no sentido de se responsabilizar a proteina quinase dependente de AMP cíclico pela fosforilaça de 56 "in vivo", porque estímulos que provocam a elevaça intracelular dos níveis de aMp cíclico levam a rapida fosforilaça de 56. Contudo, esta enzima é capaz de fosforilar apenas alguns sítios de 56 "in vitro" (Wettenhall e Morgan, 1984; Bonato et al., 1984). Recentemente foi descrita a purificaça de uma enzima que, aparentemente, é capaz de fosforilar especificamente a proteina 56 "in vitro" nos mesmos sitios verificados "in vivo" em Xenopus (Erickson e Maller, 1986).

Embora o papel da fosforilaçăo de 56 no processo de sintese proteica nåo esteja ainda elucidado, tem sido discutido o seu possivel envolvimento na iniciaço elou seletividade de tradução, uma vez que esta proteína está localizada na região de iniciaçă da subunidade 405 (Bommer et al., 1980) e pode ser quimicamente acoplada ao mRNA (Terao e Ogata, 1979; Takahashi e Ogata, 1981). Aparentemente, ribossomos com 56 maximamente fosforilada possuem alguma vantagem na formacăo de polissomos "in vivo" (Thomas et al., 1982). Além disso algumas evidências sugerem que o estado de fosforilaça de 56 teria um papel no recrutamento de mRNAs específicos (Duncan e Mcconkey, 1982) uma vez que a suplementaçăo de lisados de reticulócitos com subunidades 405 fosforiladas parece aumentar a ligaça e a 
traduçăo de RNA poli(AUG) sintético (Burkhard e Traugh, 1983).

A sugestao de que a proteina S6 exerceria algum papel no recrutamento e seleça de certos mRNAs poderia ser utilizada para explicar a capacidade das células, que foram submetidas a tratamento térmico, discriminarem entre mRNAs normais e de choque térmico. Durante o choque térmico a desfosforilaçăo da proteína 56 é coincidente com a induçăo da sintese de Hsps em Drosophila, plantas e células de mamíferos (Glover, 1982; Scharf e Nover, 1982; Kennedy et al., 1984), e a recuperaçăo do choque térmico em plantas é acompanhada pela refosforilaça de 56 (Scharf e Nover, 1982). Por outro Lado, agentes químicos que induzem a síntese de Hsps em Drosophila năo provocam a desfosforilaçăo de 56 e além disso, a refosforilaçă de 56 năo pareceu ser necessária para a retomada da síntese proteica normal após o choque térmico ( 0 lsen et al., 1983).

05 dados săo controversos e até agora nentuma correlação precisa pôde ser feita entre o estado de fosforilação de 56 e a traduçăo de mensagens normais ou específicas como aquelas de choque térmico.

Sistema de estudo: o fungo aquático Blastocladiella emersonii

Entre os diferentes sistemas biológicos utilizados como modelos experimentais para estudos dos mecanismos envolvidos no processo de diferenciação celular, os microorganismos tem 
merecido especial interesse. Muitos microrganismos unicelulares respondem a alteraçós do seu meio ambiente, com mudangas morfológicas marcantes, que sa acompanhadas por variaçăes nas suas capacidades metabolicas e fisiológicas. Devido a certas peculiaridades tais como, simplicidade estrutural, facilidades de cultivo e amplas possibilidades de manipulaça através de técnicas genéticas e bioquimicas, estes organismos provaram ser sistemas extremamente úteis no estudo dos problemas relativos ao desenvolvimento e morfogenese, incluindo aqueles relativos ao controle da expressao gênica em resposta às súbitas variaçốs ambientais. 0 fungo aquático Blastocladiella emersonii, isolado por E. Cantino em 1949, é um dos sistemas modelo que tem sido usado para tais estudos. Duas fases distintas de diferenciaça celular ocorrem durante o ciclo de vida assexuado deste fungo: a germinaça e a esporulaçă, ambas caracterizadas por mudanças profundas na arquitetura e na biogênese de organelas, podendo ser induzidas experimentalmente com alto grau de sincronia. D esquema do ciclo de vida está mostrado na página seguinte.

B.emersonii cresce como uma célula cenocítica. A caréncia nutricional a qualquer momento durante o seu crescimento, induz o processo de esporulação. Após 60-120 min da induça da esporulaçăo a célula cenocítica é convertida em um zoosporangio pela formação de um septo basal que separa o corpo nucleado do sistema rizoidal, que passa a não ser mais necessário para a nutriçăo da célula. 


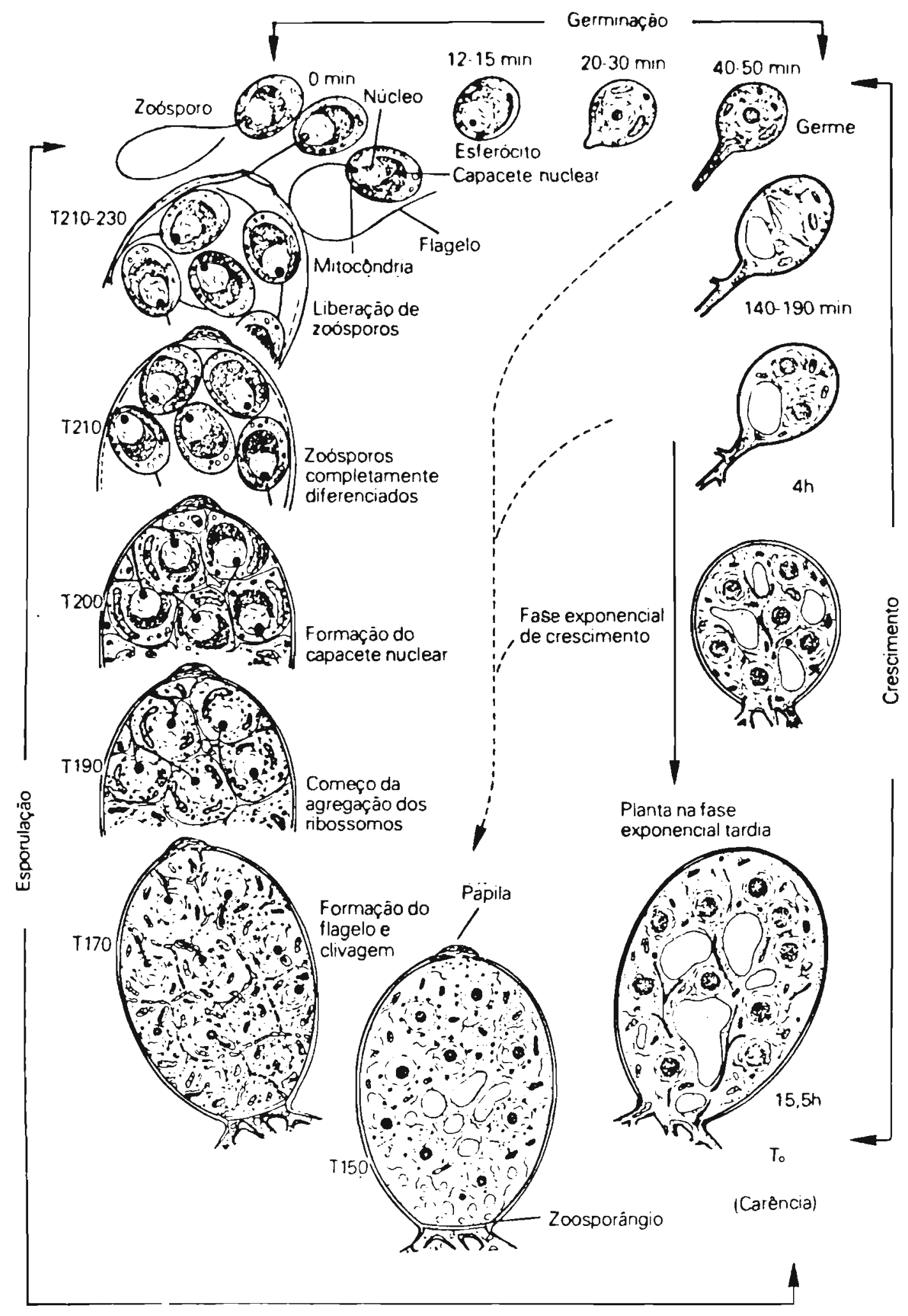

ESDUEMA DO CILO DE VIDA DO FUNGO Blastocladiella emersoni

(apud Lovett, 1975) 
Entre 90-150 min, a papila é formada na parte superior oposta à regiăo rizoidal, e logo após a formaça da papila, tem inicio a diferenciaça dos zobsporos, cujo primeiro evento é a formaça do flagelo. Paralelamente a elongaça do flagelo ocorre a citacinese e ao final desta clivagem (190 min) ocorre a formaçăo das particulas gama ccuja funçăo permanece desconhecida) e inicia-se a agregaça dos ribossomos. Os eventos finais da diferenciaça dos zoosporos incluem a rápida formaçăo do capacete nuclear e, como último evento, a reorientaçao da grande e única mitocondria ao redor do axonema $f$ lagelar. A esporulaço dura entre 3,5 e 4 horas e dependendo do tempo de crescimento anterior à carência, cada célula (zoosporângio) fornecerá um número de zoósporos que pode variar entre um até 260 e que sao liberados através da abertura da papila ( para revisăo, ver Lovett, 1975).

Durante a esporulaçă, embora nao ocorra acúmulo no conteúda celular de proteína, RNA e DNA, existe uma intensa renovaça no conteúdo de proteínas e RNAs (Murphy e Lovett, 1966; Lodi e Sonneborn, 1974; Jaworski e Thomson, 1980). Estudos com o uso de inibidores mostraram que interferências na sintese de RNA e proteínas interrompem o processo de esporulaçăo, indicando que síntese concomitante de RNA $e$ proteínas é necessária para a esporulaça normal (Murphy e Lovett, 1966). 0 aparecimento das partículas gama no final da esporulaça requer a sintese "de novo" de pelo menos duas proteínas altamente básicas de peso molecular 41 e 43 kDa 
(Hohn et al., 1984). Varias atividades enzimaticas 5 go aumentadas durante a esporulaça: guanilato ciclase (5ilverman, 1976), adenilato ciclase (Gomes et al., 1978), esterase (Barbieri e Camargo, 1975), fosfodiesterase de AMP cíclico (Maia e Camargo, 1974), fosfodiesterase de GMP ciclico (Vale e Maia, 1976), fosfatase alcalina (5elitrennikoff e Sonneborn, 1977) e proteína quinase dependente de AMP cíclico (Juliani et al., 1979). Lodi e Sonneborn (1974) relataram a existência de uma proteólise intensa durante a esporulaça. Mais tarde, foi verificado que antipaína, um inibidor de proteases, inibe o processo de esporulaça, evidenciando que a degradaço de proteínas é essencial para a conversaro das células vegetativas em zoosporângios (Correa et al., 1978).

Durante toda a esporulacgo ocorre sintese de RNA poli $(A)+$ Os RNAs poli(A)* sintetizados antes do inicio da diferenciação dos zoósporos parecem ser degradados rapidamente, enquanto os novos RNAs poli(A)+ sintetizados no final da esporulação é que, aparentemente, sao conservados nos zoósporos. Este acúmulo de novos RNAs poli( $(A)+$ nos últimos 30 minutos da esporulaçăo coincide com a formaçăo do capacete nuclear do zósporo dentro do qual o RNA poli(A). estará sequestrado (Jaworski e Thomson, 1980), e também com a sintese de certas proteínas. Estas proteínas săo sintetizadas nos momentos finais da esporulaçăo (180-210 min) $e$ são encontradas associadas às partículas ribonucleoproteicas. Estas particulas poderiam ter o papel 
de armazenar o mRNA neste periodo em que RNA poli(A). estável é acumulado. Durante a germinaça dos zobsporos foi observado o desaparecimento destas proteinas da fraça ribossomal (Jaworski e Stumhofer, 1981).

Os zoósporos săo células altamente diferenciadas, desprovidas de parede celular, capazes de nadar por um longo período de tempo na ausencia de nutrientes, as custas de suas reservas endógenas. Ds zoósporos sgo inativos quanto à síntese de proteínas e de RNA, embora eles contenham quase todos os componentes necessarios para a síntese proteica, incluindo aminoacil-tRNAs carregados, RNA poli(A)+, fatores de iniciaçăo e elongaça e ribossomos, organizados em uma organela denominada capacete nuclear que está justaposta ao núcleo (Jaworski, 1976; Johnson et al., 1977; Schmoyer e Lovett, 1969; Gong e Lovett, 1977).

- processo de germinação dos zoósporos pode ser induzido rapida e sincronicamente em meio nutriente ou em solução inorgânica contendo certos fons monovalentes, AMP ciclico ou inibidores da fasfodiesterase de AMP ciclico (5oll e Sonneborn, 1972; Gomes et al., 1980; Gottschalk e Sonneborn, 1982). Os zoósporos cessam seu movimento, retraem - flagelo e formam uma fina parede de quitina, transformando-se em células redondas nos primeiros $10-15$ minutos após indução da germinação. Em seguida estas células redondas transformam-se em germes com a formaçăo de um tubo germinativo visível que começa a se ramificar aos $60 \mathrm{~min}$ e que é o precursor do sistema rizoidal da célula em 
crescimento (Lovett, 1975). Gottschalk e Sonneborn (1982) relataram a existencia do fator de manuntença de zoósporos, um derivado de nucleotideo cielico, que é liberado para o meio extracelular durante a esporulaço e que aparentemente é capaz de bloquear a transformaça do zoósporo para célula redonda.

A transição de zoósporo para célula redonda ou esferócito năo é dependente da sintese de RNA e proteinas e a transiça de esferócito para germe é dependente da sintese de proteínas mas não de RNA (Lovett, 1968). Entretanto o desenvolvimento do rizóide após 45-50 min de germinação năo ocorre na presença de actinomicina $D$ e se presume que seja então necessaria a síntese de novos mRNAs (Leaver e Lovett, $1974)$.

Assim, sintese de RNA não é necessária para o aumento de sintese de proteínas que ocorre no inicio da germinaça, e a traducão do mRNA transcrito durante a esporulaçăo e estocado no zobsporo é responsável pelo rápido aumento no conteúdo de polissomos que ocorre entre 15 e $30 \mathrm{~min}$ de germinação (Lovett, 1968; 5oll e Sonneborn, 1971a; Leaver e Lovett, 1974; Silverman et al., 1974; Jaworski e Thomson, 1980). Durante a rápida conversao dos zoósporas a esferócitos, $50 \%$ dos ribossomos estăo na forma de polissomos e aos $60 \mathrm{~min}$ de germinaça em meio nutriente, $70 \%$ dos ribossomos estaro como polissomos. Em células germinadas em meio inorgânico, a fração de polissomos alcança um nível de $50 \%$ aos $60 \mathrm{~min}$. E provável que os novos mRNAs sintetizados 
38.

contribuam para esta elevaça no nível de polissomos após aquele aumento inicial em que foram utilizados os mRNAs armazenados nos zobsporos (Leaver e Lovett, 1974).

Ds zoósporos contém tanto RNAs poli(A)+ como RNAs poli(A)- armazenados, embora nao sejam conhecidas as suas proporçoes em massa (Jaworski, 1976; Johnson et al., 1977; Lovett, 1983). Parte do RNA poli(A)+ que está sequestrado no zobsporo corresponde ao RNA poli(A)+ sintetizado durante o crescimento antes da indução da esporulaça lJaworski e Thomson, 1980). Ds zoósporos armazenam RNA total que representa $42 \%$ da complexidade total do genoma (simples cópia) com cerca de 45\% desta complexidade representada por RNA poli(A)+, 36\% como RNA poli(A)- de sequencias distintas, e 15\% em ambas as frações (Lovett, 1983). Resultados de Jaworski et al. (1976) demonstraram que há um intenso metabolismo dos fragmentos poli( $(A)$ nos 45 minutos iniciais da germinaçăo, incluindo tanto degradaçăo como adiçăo de fragmentos poli(A) nos mRNAs armazenados nos zoosporos.

C Ciclo de vida de Blastocladiella emersoni possui, portanto, características que propiciam a utilizaçăo deste microorganismo para estudos sobre o controle da expressão gênica envolvida no processo de diferenciação celular. Assim, neste trabalho nos propusemos a estudar o contrale da expressăo gênica durante as duas fases de diferenciação celular, esporula̧̧a e germinaçăo, deste organismo.

Utilizando a incorporaçăo "in vivo" de lss5/metionina na forma de pulsos curtos e consecutivos e a técnica de 
eletroforese bidimensional - que tem se demonstrado uma importante ferramenta na analise da quantidade e natureza das alteraçóes no padra de proteínas que ocorrem durante o processo de diferenciaçăo celular - investigamos possiveis variaçoses no padrao das proteínas sintetizadas durante a esporulaçăo a germinaça. Para verificar se as variaçơs no padra de síntese proteica eram acompantadas ou ngo de variaçoes na populaçăo de RNAs, foram feitos ensaios de traduçă "in vitro" utilizando RNAs isolados durante a esporulaçăo e a germinaçăo. Além disso, nos pareceu interessante tentar identificar actina e tubulina entre as proteínas cuja sintese estivesse sob um controle do desenvolvimento, através da utilizaça de anticorpos comerciais contra estas proteínas.

A este estudo seguiu-se, uma investigaça sobre a resposta ao choque térmico durante o desenvolvimento em B.emersonii. 0 surgimento de alguns dados na literatura sugerindo um controle do desenvolvimento superposto a resposta transitória induzida pela hipertermia, nos levou a utilizar o fungo B.emersoni para investigarmos até que ponto o programa de desenvolvimento normal seria afetado ou afetaria a resposta ao choque térmico. Este estudo nos levau à verificaçăo que três proteínas de choque térmico 5 ăo expressas espontaneamente durante a esporulaçao (Hsp70, Hsp76 e Hsp39a), sendo que a identidade entre a Hsp70 a a proteína de $70 \mathrm{kDa}$ induzida espontaneamente durante um certo estágio da esporulaçăo foi investigada. 
40.

\begin{abstract}
Assim, em B.emersanii, verificamos que sobre o controle da ativação transitoria de genes de choque térmico aparentemente está superposto um controle do desenvolvimento, representado pela induça de conjuntos específicos de Hsps em cada fase do desenvolvimento de Blastocladiella emersonii. Contudo, algumas Hsps podiam ser induzidas pela hipertermia em todas as fases do ciclo de vida. Este fato proporcionou a oportunidade de analisarmos como se comportaria o fenômeno de aquisiçăo de termotolerância em cada uma dessas fases do desenvolvimento e quais Hsps estariam envolvidas neste processo.

Finalmente, retomamos um estudo já iniciado em nosso laboratorio sobre o papel da fosforilaço da proteina ribossomal 56 (Bonato et al., 1984), agora no contexto da resposta ao choque térmico. Assim, investigamos o efeito do choque térmico na fosforilaça desta proteina levando em consideraçăo as observaçoes anteriores de que o estado de fosforilação de 56 varia durante o desenvolvimento de Blastocladiella e a nossa observaço de que existe um controle do desenvolvimento sobre a resposta ao choque térmico.
\end{abstract}




\section{PROCEDIMENTOS EXPERIMENTAIS}

1. Condiçaes de cultivo e obtenção das células

1.1. Manutençáa das culturas e obtençăo dos zoósporos de primeira geraço

As culturas de B.emersonii mantidas em placas de Petri contendo meio PYG-ágar (peptona $0,125 \%$, extrato de levedura 0,125\%, glicose $0,3 \%$, ágar 1\%) foram renovadas diariamente pela semeadura de zoósporos, os quais, após germinarem aderidos à superficie do agar, crescem vegetativamente por 20-24 horas a $19^{\circ} \mathrm{C}$ completando o ciclo de vida através de uma esporulaçăo espontânea. Os novos zoósporos liberados, chamados "zoosporos de primeira geraça" foram coletados através de ressuspensaro em água destilada e utilizados para semeadura de novas placas ou inoculados em meio de crescimento (íquido (DM3 e PYG-P).

As células vegetativas crescem lentamente a baixas temperaturas, 0 que permitiu estoca-las a $4^{\circ} \mathrm{C}$ durante o fim de semana. O desenvolvimento normal foi retomado incubandose essas células a $24^{\circ} \mathrm{C}$, induzindo-se a esporulaça em 6-7 horas pela adiçăo de água destilada. 


\subsection{Cultivo em meio liquido PYG-P para obtenço de grandes quantidades de zóosporos}

Ds zoosporos de primeira geraça $(7 \times 107)$ foram, imediatamente após a colheita, inoculados em um litro de meio PYG-P cpeptona 0,125\%, extrato de Levedura 0,125\%, glicose $\left.0,15 \%, \mathrm{KH}_{2} \mathrm{PO}_{4} 2,5 \mathrm{mM}, \mathrm{K}_{2} \mathrm{HPO} 42,5 \mathrm{mM}\right)$ num frasco de Fernbach (Goldstein e cantino, 1962). Após 14 horas de crescimento a $23^{\circ} \mathrm{C}$, sob agitaçăo (160 rpm), as células vegetativas foram filtradas em rede de nailon ( $30 \mu m)$, lavadas com soluça de esporulaçăo (Tris-maleato $1 \mathrm{mM}$, pHG, 8, [a[l $21 \mathrm{mM})$ e ressuspensas em $400 \mathrm{ml}$ desta mesma soluçăo. Após 4 horas a $27^{\circ} \mathrm{C}$ sob agitaçăo podia-se observar 95\% a 100\% dos zoosporângios vazios, que foram entao separados dos zoósporos por filtraça em rede de náiton. Para um litro de meio PYG-P obtinhamos cerca de $5 \times 10^{\circ}$ zoósporos. Estes zoósporos foram utilizados para a purificasão de tubulina de flagelos (1 tem II.12).

\subsection{Indução da esporulação e germinaçăo sincrônicas}

Para a induçăo da esporulaçăo sincrônica, o crescimento das células foi feito em meio de crescimento semi-definido DM3. Este meio é uma modificaçăo do meio definido de crescimento, DM2, descrito por 5elitrennikoff e Sonneborn (1977). A composiçăo do meio DM3 a seguinte: $\left[a\left[l_{2} \quad 1 \mathrm{mM}\right.\right.$, $\mathrm{MgSO}_{4} \quad 10 \mathrm{mM}, \quad \mathrm{FeSO}_{4} \cdot 7 \mathrm{H}_{2} \mathrm{O} 0,6 \mu \mathrm{g} / \mathrm{ml}, \quad\left[\mathrm{uSO}_{4} \cdot 5 \mathrm{H}_{2} \mathrm{O} 0,1 \mu \mathrm{g} / \mathrm{mL}\right.$, 
$\mathrm{Zn50}, .7 \mathrm{H}_{2} \mathrm{O} \quad 0,2 \mu \mathrm{g} / \mathrm{ml}, \mathrm{MnSO}_{4} \cdot \mathrm{H}_{2} \mathrm{O} 0,2 \mu \mathrm{g} / \mathrm{ml}, \mathrm{glicose} 0,33 \%$, tiamina $0,04 \mu \mathrm{g} / \mathrm{ml}, \quad \mathrm{glicina} 0,2 \mathrm{mM}, \quad L-h i s t i d i n a 0,13 \mathrm{mM}, \quad$ Lisoleucina $0,4 \mathrm{mM}, \quad L-L i s i n a H C L 0,4 \mathrm{mM}, L$-metionina $0,1 \mathrm{mM}, L$ fenilalanina $0,2 \mathrm{mM}, \quad L-s e r i n a 0,2 \mathrm{mM}, \quad L$-treonina $0,4 \mathrm{mM}, \quad L$ triptofano $0,04 \mathrm{mM}, \quad L$-tirosina $0,2 \mathrm{mM}$, valina $0,4 \mathrm{mM}, \quad L$ arginina $0,24 \mathrm{mM}$, ácido glutâmico $2,7 \mathrm{mM}$, extrato de levedura $120 \mathrm{ng} / \mathrm{ml}, \mathrm{NaH}_{2} \mathrm{PO}_{4} / \mathrm{Na}_{2} \mathrm{HPO}_{4} \quad 1 \mathrm{mM}, \mathrm{pHG}, 8$, Tris-maleato $3,5 \mathrm{mM}$, pHG,8; O pH do meio foi ajustado para $6,8 \mathrm{com} K O H \quad 1 M$ e a concentraça final de $K+$ foi ajustada para $25 \mathrm{mM}$ com KCl $1 M$.

Zoósporos de primeira geraça foram inoculados em meio Liquido DM3 na densidade de $3 \times 10$ zósporos/ml, sendo utilizado no máximo $500 \mathrm{ml}$ de meio em cada frasco de Fernbach. Após 14 horas de crescimento a $19^{\circ}[$, sob agitaçăo (160 rpm), as células vegetativas foram filtradas em rede de náilon $(30 \mu m)$, lavadas com soluçăo de esporulagro (com aproximadamente uma quantidade equivalente a 3 vezes 0 volume do meio de (rescimento), suspensas nesta mesma soluçaro na concentração de $5 \times 10^{5}$ células/ml e mantidas a $27^{\circ}[$ por 4 horas sob agitaça. D progresso e a sincronia da esporulação foram acompanhados ao microscópio óptico. Após 2 horas de esporulaçăo 95-100\% das células apresentavam papila e após 4 horas os zoosporos eram liberados para o meio. As células esporulantes foram coletadas nos diferentes momentos da esporulaçăo por filtraçăo a vácuo em papel whatman $n^{\circ} 1$ ou por centrifugaçăo $(1000 \times g, 5 \mathrm{~min})$. D sedimento obtido foi imediatamente congelado em gelo secolacetona ou tratado com TCA 10\% como descrito no item II. 2. 
Os zoosporos obtidos apos esporulaģo sincrônica foram separados das células vegetativas vazias por filtraça em rede de náilon e o seu número foi determinado por contagem em camara de Neubaver. Para $500 \mathrm{ml}$ de meio DM3 $\left(1,5 \times 10^{\circ}\right.$ células) obtinhamos uma producăo de zoósporos variando entre $1,2-1,5 \times 10$ zósporos totais. A seguir os zoósporos foram coletados por centrifugas a $(1000 \times g, 5 \mathrm{~min})$ e imediatamente congelados em gelo secolacetona ou tratados com TCA $10 \%$.

Para as experiências de germinaça, foram obtidos zoósporos como deserito no parágrafo anterior. Após a centrifugaçăo $\left(1000 \times g, 5 \mathrm{~min}, 4^{\circ} \mathrm{C}\right)$, os zoósporos foram ressuspensos em soluçăo de esporulaçăo gelada na concentraçăo de $1 \times 10$ zoósporos/ml e em seguida inoculados no meio apropriado na densidade de $1 \times 106$ zoósporos/ml e mantidos a $27^{\circ} \mathrm{C}$ sob agitaça $(160 \mathrm{rpm})$. o progresso e a sincronia da germinaça foram acompanhados ao microscópio óptico. Após $20 \mathrm{~min}, 100 \%$ das células correspandiam ao fenótipo de célula redonda e após 45 min 100\% haviam desenvolvido o fenótipo germe.

Ds meios utilizados para a indução da germinaçăo foram: meio LM3, soluçăo inorgânica de germinaçăo (Tris-maleato $1 \mathrm{mM}, \mathrm{pHG}, 8,\left[\mathrm{a} C \mathrm{l}_{2} 1 \mathrm{mM}, \mathrm{Mg}\left[\mathrm{l}_{2} 10 \mathrm{mM}, \mathrm{KCl} 50 \mathrm{mM}\right)\right.$, meio $\mathrm{AL}\left(C_{a}\left[\mathrm{l}_{2}\right.\right.$ $1 \mathrm{mM}, \mathrm{MgCl}_{2} 10 \mathrm{mM}, \mathrm{FeSO}_{4} .7 \mathrm{H}_{2} \mathrm{O} 0,6 \mathrm{\mu g} / \mathrm{mL},\left[u S O_{4} .5 \mathrm{H}_{2} \mathrm{O} 0,1 \mathrm{ng} / \mathrm{ml}\right.$, $\mathrm{ZnSO}_{4} \cdot 7 \mathrm{H}_{2} \mathrm{O} 0,2 \mu \mathrm{g} / \mathrm{ml}, \mathrm{MnSO}_{4} \cdot \mathrm{H}_{2} \mathrm{O} 0,2 \mu \mathrm{g} / \mathrm{ml}, \mathrm{glicose} 0,3 \%$, tiamina $0,04 \mu \mathrm{g} / \mathrm{mL}, \quad 0,2 \mathrm{mM}$ dos seguintes aminoácidos: L alanina, L-fenilalanina, L-ácido aspártico, L-cisteína, Lhidroxiprolina, L-prolina, L-leucina, L-isoleucina, L-ácido 
glutamico, glicina, L-serina, L-tirosina, L-arginina, LLisina, L-treonina, L-valina, L-histidina, L-triptofano; metionina 5 $\mu M, \mathrm{NaH}_{2} \mathrm{PO}_{4} / \mathrm{Na}_{2} \mathrm{HPO}, 1 \mathrm{mM}$ pHG, 8 , Tris-maleato $1 \mathrm{mM}$, pHG, 8; o pH do meio foi ajustado para 6,8 com KOH $1 M$ e a concentraçăo de $K+$ foi ajustada para $50 \mathrm{mM}$ com K[l 1M). Foram coletadas células nos diferentes momentos da germinaço por filtraçăo a vácuo em papel Whatman $n^{01}$ (exceto as celulas germinantes de até $30 \mathrm{~min})$ ou por centrifugaço (1000xg, 5 min). D sedimento obtido foi imediatamente congelado em gelo secolacetona ou tratado com TCA 10\% como descrito no item II 2 .

\subsection{Condições para o tratamento térmico das células}

Nos experimentos de choque térmico, as células em diferentes momentos do ciclo de vida a $27^{\circ} \mathrm{C}$, foram transferidas para $34^{\circ}, 38^{\circ}, 40^{\circ}$ ou $42^{\circ} \mathrm{C}$, permanecendo nestas temperaturas por um tempo que variou entre 10 e $60 \mathrm{~min}$, dependendo do tipo de experimento. D aquecimento das células foi feito em banho-maria nas diversas temperaturas, com agitaçăo manual das culturas. Após o intervalo de choque térmico as células foram coletadas como descrito no ítem II.1.3, ou transferidas para $27^{\circ} \mathrm{C}$ quando se pretendia analisar a recuperaçăo das células. Para a determinação da viabilidade, as células (germes ou células em crescimento), depois de submetidas ao tratamento térmico, foram retornadas à temperatura normal $\left(27^{\circ} \mathrm{C}\right)$. Após 4 horas de recuperaçara, a 
esporulaçăo foi induzida e o número de zoósporos liberados após 4 horas determinado.Para a delerminaça da viabilidade durante a esporulaço, os zoosporangios que sofreram tratamento térmico foram retornados a $27^{\circ} \mathrm{C}$ e apos 6 horas de recuperaça o número de zósporos liberados foi determinado.

\subsection{Incorporaço "in vivo" de |sss/metionina}

Para a incorporaça "in vivo" de lass/metionina durante a esporulaçăo ou germinaçăo sincrônicas, alíquotas de $6 \times 10$ o

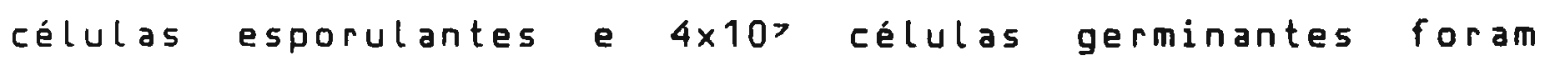
removidas nos tempos indicados, jas/metionina ( $1-2 \mu[i / m l$, da Amersham) foi adicionada ao meio e após $30 \mathrm{~min}$, no caso da esporulaçăo, ou $10 \mathrm{min,} \mathrm{no} \mathrm{caso} \mathrm{da} \mathrm{germinaçăo,} \mathrm{as} \mathrm{células}$ foram centrifugadas $(1000 \times 9,5 \mathrm{~min})$ e o sedimento ressuspenso em $10 \mathrm{ml}$ de TCA $10 \%$ gelado contendo metionina $1 \mathrm{mg} / \mathrm{mL}$.

a tempo de incubaçăo das células (pulso) na presença de las |metionina variou em alguns experimentos, principalmente aqueles envolvendo choque térmico. Nestes casos, as tempos de pulso estao indicados na apresentaça dos resultados. 
1.6. Incorporacao "in vivo" de szPi

Nos experimentos de marcaça com $32 \mathrm{Pi}$ a incorporaģo foi feita ao longo de todo o ciclo de vida. Co sapi foi adquirido da Comissaro Nacional de Energia Nuclear, [NEN/SP). A incorporaço foi iniciada durante o crescimento em meio DM3 contendo menor concentraço de fosfato $(0,1 \mathrm{mM})$ como descrito no ftem II.1.3, exceto que $32 \mathrm{Pi}(10 \mu[\mathrm{i} / \mathrm{ml})$ foi adicionado ao meio. Após o crescimento, a esporulaçăo foi induzida na presenca de $10 \mu[\mathrm{i} / \mathrm{ml}$ de $32 \mathrm{Pi}$ e os zoósporos radioativamente marcados foram induzidos a germinar em soluça inorganica contendo $32 \mathrm{Pi} \quad(10 \mu[\mathrm{i} / \mathrm{ml})$. Os diferentes fenótipos celulares foram coletados por centrifugacgo $(1000 \times g, 5 \mathrm{~min})$ e o sedimento foi ressuspenso em $10 \mathrm{~mL}$ de TCA $10 \%$ gelado.

2. Extração das proteínas totais das células para análise em eletroforese em gel de poliacrilamida

\footnotetext{
- sedimento das células marcadas ou nåo com jas/metionina ou $32 \mathrm{Pi}\left(6 \times 10^{\circ}\right.$ células vegetativas ou esporulantes ou $4 \times 10>$ zósporos ou células germinantes) foi ressuspenso em $10 \mathrm{ml}$ de TCA 10\%, gelado, sob vigorosa agitaça. Esta suspensăo foi mantida a $4^{\circ} \mathrm{C}$ por no mínimo 30 mine, em seguida, centrifugada a 1000xg por $20 \mathrm{~min}$. D sedimento obtido foi dissolvido em $0,5 \mathrm{ml}$ de $\mathrm{NaOH} 0,3 \mathrm{~N}$, sendo em seguida adicionado $1,2 \mathrm{ml}$ de água destilada. Em
} 
seguida procedeu-se à sonicagaro das células em Sonicador Branson (microtip, poténcia $n^{\bullet 4}, 20$ segundos por duas vezes), em banho de gelo. Esta etapa de sonicaça é essencial para completa solubilizaça das proteínas. Uma alíquota de $100 \mu l$ foi removida para a dosagem de proteínas (pelo método de Lowry et al., 1951) imediatamente após a sonicaçăo a restante da amostra foi adicionado TCA gelado para concentraça final de $10 \%(0,16 \mathrm{ml}$ de TCA $100 \%+5 \mathrm{ml}$ de TCA 10\%). Após incubaço por uma noite a $4^{\circ} \mathrm{C}$ a suspensgo foi centrifugada a $4000 \times g$ por $15 \mathrm{~min}$. 0 sedimento foi ressuspenso em etanol absoluto $(5 \mathrm{ml})$ e mantido a $4^{\circ} \mathrm{C}$ por 15 min e em seguida centrifugado $4000 \times 9$ por 15 min. D sedimento obtido foi ressuspenso em $5 \mathrm{ml}$ de uma mistura de clorofórmio:metanol (1:1). Após 15 min a $4^{\circ}[$, a suspensaro foi centrifugada $(4000 \times 9,15 \mathrm{~min})$. Após evaporaça a vácuo o precipitado obtido foi armazenado a $-20^{\circ} \mathrm{C}$ e no dia da eletroforese ressuspenso em tampao de amostra para eletroforese unidimensional (Laemmli, 1970) ou em tamparo de amostra para eletroforese bidimensional Curéia 9,5M, Nonidet P-40 2\%, ditiotreitol $10 \mathrm{mM}$ e anfolitos $2 \%$ ) (D'farrell, 1975).

3. Determinaça da radioatividade incorporada em proteínas

Nos experimentos de incorporaço "in vivo" de lass/metionina a quantidade de radioatividade incorporada em proteínas foi determinada por precipitaça com TCA. 
Imediatamente após a ruptura das células por sonicaça, uma allquota $(10 \mu l)$ foi pipetada, simultaneamente com albumina de soro bovino $(50 \mu g)$, em pedaço $(1 \times 1 \mathrm{~cm})$ de papel Whatman 3MM (previamente mergulhado em uma soluça de TCA $10 \%$ contendo metionina $1 \mathrm{mg} / \mathrm{ml}$ ). Ds pedaços de papel foram Lavados por 4 vezes $(10 \mathrm{~min}$ cada) com TLA $10 \%$ contendo metionina $1 \mathrm{mg} / \mathrm{ml}$, sendo que a segunda lavagem foi feita a $90^{\circ}$ C para eliminar metionil-tRNA. A seguir os papéis foram Lavados com etanol, secos e a radioatividade foi medida em contador de cintilaçăo.

\section{Extraçăo e purificaçăo de RNA}

\subsection{Obtençăo de RNA total}

- RNA total foi isolado segundo o procedimento descrito por Chirgwin et al. (1979) que envolve ruptura das celulas na presença de isotiocianato de guanidina e $\beta$-mercaptoetanol com o objetivo de inibir eficientemente ribonucleases. D RNA foi, entao, isolado livre de proteinas e DNA por ultracentrifugação em cloreto de césio como descrito por Maniatis et al. (1982).

- sedimento congelado tanto de células vegetativas como de células esporulantes $(7 \times 10)$ células), de zoósporos $\left(1,5 \times 10^{\circ}\right)$ ou de células germinantes $\left(8 \times 10^{\circ}\right)$ foi ressuspenso em $2,5 \mathrm{ml}$ da seguinte soluçăo: isotiocianato de guanidina 4M, citrato de sódio $25 \mathrm{mM}, \mathrm{pH7}$, Lauril sarcosinato de sódio 2\%, 
B-mercaptoetanol $0,1 M$. Os zoósporos lisaram pelo simples congelamento e descongelamento. Ds demais tipos celulares foram submetidos à sonicação (microtip de sonicador Branson potência $n^{\circ} 4 ; 20$ segundos por 2 vezes). 0 lisado celular foi centrifugado a $4000 \times g$ por $10 \mathrm{~min}$ a ao sobrenadante foi adicionado $1 \mathrm{~g}$ de $[s[l$, e, em seguida este sobrenadante foi submetido a centrifugaçăo sobre uma camada de $[s[15,7 M$ em EDTA $0,1 M(p H 7,5)$, densidade $1,78819 \mathrm{~g} / \mathrm{cm}^{3}$, por 13 horas a $36000 \mathrm{rpm}$ (rotor 5pinco 5W50.1). D sedimento contendo o RNA foi dissolvido em $1 \mathrm{ml}$ de Tris-HCl $10 \mathrm{mM}, \mathrm{pH} 7,4$, EDTA $5 \mathrm{mM}$, 5DS $1 \%$ e extraído com $1 \mathrm{ml}$ de clorofórmio:1-butanol (4:1). A fase aquosa foi transferida para um tubo e a fase organica foi reextraida com volume igual de Tris-HCl $10 \mathrm{mM}, \mathrm{pH} 7,4$, EDTA $5 \mathrm{mM}, 5 \mathrm{~S} 5$ 1\%. As fases aquosas foram reunidas e o RNA foi precipitado pela adiçăo de 0,1 volume de acetato de sódio $3 M$ (pH5,2) e 2,2 volumes de etanol gelado. Após incubaçăo a $-20^{\circ} \mathrm{C}$ por uma noite, o RNA foi coletado por centrifugaça $(13000 \times g, 10 \mathrm{~min})$, ressuspenso em água $(0,5 \mathrm{ml})$ e precipitado novamente com acetato de sódio e etanol. Após centrifugaçăo - sedimento foi seco sob vácuo, ressuspenso em água e armazenado a $-70^{\circ}$ C. A quantidade de RNA obtida foi estimada pela leitura da densidade optica a $260 \mathrm{~nm}$. A integridade do RNA obtido foi verificada através de eletroforese em gel de agarose. Todos os cuidados para evitar a contaminaça da preparação de RNA com ribonucleases foram tomados. 0 material de vidro foi esterilizado a $180^{\circ} \mathrm{C}$ por 14 horas em forno Pasteur e o material de plástico foi esterilizado em 
autoclave. As soluçăes for am preparadas de maneira estéril com reagentes ultra-puros (livres de nucleases) e quando possivel foram esterilizadas em autoclave depois de prontas.

\subsection{Purificaçăo de RNA poli(}

Os RNAs poliadenilados (RNAs poli( $(A)+$ ) foram separados dos RNAs nåo poliadenilados (RNAs poli(A)-) através de cromatografia em coluna de oligo(dT)-celulose como descrito por Ruiv e Leder (1972).

A oligo(dT)-celulose $(0,19$, da Collaborative Research, Inc.) foi equilibrada em tamparo A (Tris-HCl 20mM, pH7,6, LiCL $0,5 M$, EDTA $2 \mathrm{mM}$, SDS $0,4 \%)$ e colocada em uma seringa de $1 \mathrm{ml}$. A coluna foi entao lavada com 3 volumes de $\mathrm{H}_{2} \mathrm{D}, 3$ volumes de $\mathrm{NaDH} 0,1 \mathrm{M}$ em EDTA $5 \mathrm{mM}$ e novamente com $\mathrm{H}_{2} \mathrm{O}$ até o $\mathrm{pH}$ do efluente ser menor que 8,0. Em seguida, a coluna foi lavada com 5 volumes de tamparo $A$. Ao RNA dissolvido em $\mathrm{H}_{2} \mathrm{O}$ $(1 \mathrm{mg} / 0,5 \mathrm{ml})$, previamente aquecido a $65^{\circ} \mathrm{C}$ por $5 \mathrm{~min}$, adicionou-se igual volume do tamparo $A$ duplamente concentrado e após resfriamento o RNA foi aplicado na coluna. o eluato foi coletado, aquecido a $65^{\circ} \mathrm{C}$, resfriado e aplicado novamente na coluna. Essa etapa foi repetida mais uma vez. A coluna foi entao lavada com 5-10 volumes de tamparo $A$. A eluiçăo do RNA poli(A)- foi acompantada por leitura da densidade óptica a $260 \mathrm{~nm}$. Após total eluigăo do RNA poli(A)procedeu-se a eluiçăo do RNA poli $(A)+$ através de lavagem da coluna com 2-3 volumes de: Tris-HCl 10mM, pH7,5, EDTA 1mM. A 
eluição foi acompanhada por leitura da densidade óptica das fraçŏes a $260 n m$. As fracŏes com maior densidade óptica foram reunidas e o RNA poli( $($ ) + foi precipitado pela adiça de 0,1 volume de acetato de potássio $2 M, p H 5,0$ e 2,2 volumes de etanol absoluto a $-20^{\circ} \mathrm{C}$. Após uma noite a $-20^{\circ} \mathrm{C}$, o RNA poli(A)+ foi coletado por centrifugaça (13000xg, $10 \mathrm{~min})$, Lavado uma vez com etanol e seco sob vácuo. D precipitado obtido foi dissolvido em água e armazenado a $-70^{\circ} \mathrm{C}$.

5. Traduça do mRNA em lisado de reticulócitos de coelho

O Lisado de reticulócitos foi preparado de acordo com Pelham e Jackson (1976) e Jackson e Hunt (1983) e nos foi gentilmente cedido pelos Drs. Cecilia Santos e Ricardo Brentani. A cancentração final dos constituintes na mistura de reaçăo $(25 \mu l)$ foi: creatina fosfato $8 \mathrm{mM}$, 19 L-aminoácidos (exceto metionina) $50 \mu M$, acetato de magnésio $0,5 \mathrm{mM}$, acetato de potássio 120mM, pH7,5, 16ul do lisado de reticulócitos,

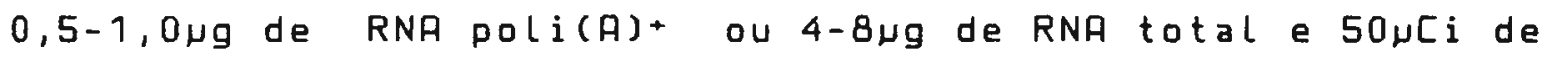
jas/metionina. $\quad A$ mistura de reaçăo foi incubada por 90 min a $30^{\circ}[$. Para análise dos produtos resultantes da tradução "in vitro" através de eletroforese unidimensional, uma aliquota de $5 \mu l$ foi, imediatamente após a reaçăo, ressuspensa em $50 \mu l$ do tampão da amostra para gel unidimensional e fervida por $3 \mathrm{~min}$. O restante da mistura de reação (20ul) foi ressuspenso em $20 \mu l$ de tampåo de amostra para gel bidimensional duplamente concentrado (uréia 9,5M, 
NP-40 4\%, DTT $20 \mathrm{mM}$ ) sem anfolitos. A concentraça da uréia foi corrigida pela adiça direta de cristais para a concentraça final de $9,5 M$ e a dos anfolitos foi também corrigida para $2 \%$ de acordo com o sistema eletroforético a ser utilizado (IEF/SDS ou NEPHGE/SDS).

Alguns experimentos de traduça "in vitro" foram feitos utilizando-se lisado de reticulócitos comercial (da Amersham). Neste caso ao lisado $(20 \mu l)$ foi adicionado apenas RNA e jas/metionina $(50 \mu[i)$, seguindo-se a uma incubaçăo por $90 \mathrm{~min}$ a $30^{\circ} \mathrm{C}$.

6. Eletroforese de proteínas em gel de poliacrilamida contendo SDS

\subsection{Eletroforese unidimensional}

Foi adotado o sistema de Laemmli (1970), utilizando-se géis de separação de $14 \mathrm{~cm}$ de largura por $8,5 \mathrm{~cm}$ de altura e $1 \mathrm{~mm}$ de espessura. A concentraçă de acrilamida foi de $10 \%$ no gel de separação e $4,5 \%$ no de empilhamento. As amostras foram dissolvidas no tampão de amostra (soluçăo D: Tris-HCL $62,5 \mathrm{mM}, \mathrm{pHG}, 8$, SDS 2,3\%, glicerol 10\%, DTT $1 \mathrm{mM})$ e fervidas por 3 min. Após resfriamento foi adicionado azul de bromofenol $0,01 \%$ e DTT $25 \mathrm{mM}$ e em seguida as amostras foram imediatamente aplicadas no gel. As amostras estavam em volumes não maiores que 50ul, contendo 20-40ug de proteínas totais da célula por canaleta. Como padra de peso 
molecular foi usada uma mistura contendo $3 \mu g$ das seguintes proteinas de peso molecular conhecido: albumina de soro bovino ( $67 \mathrm{kDa}$ ), IgG (55 e $25 \mathrm{kDa}$ ), ovoalbumina (45 kDa) e lactoglobulina (18 kDa).

As corridas eletroforéticas foram desenvolvidas com amperagem constante de $15 \mathrm{~mA}$ até ultrapassagem do gel de empilhamento e $20 \mathrm{~mA}$ (no máximo 200 volts) no gel de separaçăo, sendo interrompidas quando a linha do corante azul de bromofenol atingia a extremidade inferior do gel.

Após a eletroforese o gel foi corado e fixado com azul de Coomassie $0,2 \%$ em metanol $50 \%$ e ácido acético $10 \%$ e descorado em metanol $30 \%$ e ácido acético $7 \%$. Antes da secagem a vácuo o gel foi mergulhado por $30 \mathrm{~min}$ em solução de metanol $5 \%$ e ácido acético $7 \%$ contendo glicerol $3 \%$.

Quando as proteínas estavam marcadas radioativamente com lass/metionina, o gel, após o descoramento, foi submetido a tratamento com o reagente fluorográfico Amplify (da Amersham) por $30 \mathrm{min,} \mathrm{seco} \mathrm{a} \mathrm{vácuo} \mathrm{e} \mathrm{exposto} \mathrm{a} \mathrm{filme} \mathrm{de}$ Raios-X (da Kodak) a $-70^{\circ} \mathrm{C}$.

\subsection{Eletroforese bidimensional}

Foram empregados dois métodos de eletroforese bidimensional em gel de poliacrilamida: IEF/SDS (focalizaçăo isoelétrica, D'Farrell, 1975) e NEPHGE/SDS (eletroforese de não-equilibrio em gradiente de $\mathrm{pH}$, o'farrell et al., 1977). Em ambos os métodos as proteínas sao separadas na primeira 
dimensăo, de acordo como o ponto isoelétrico, através de focalizaçăo isoelétrica e na segunda dimensăo, de acordo com - peso molecular, através de eletroforese em géis contendo SDS. 0 sistema NEPHGE/SDS separa além das proteínas ácidas, as proteínas mais básicas.

A eletroforese da primeira dimensă foi realizada em tubos de vidro com $2,5 \mathrm{~mm}$ de diâmetro e $130 \mathrm{~mm}$ de comprimento, preenchidos com a mistura do gel (uréia 9,2M, Nonidet P-40 2\%, acrilamidalbisacrilamida $4 \%$, anfolitos $2 \%$ ) até a altura de $115 \mathrm{~mm}$. A polimerização do gel foi feita pela adiçăo de persulfato de amônio $(0,02 \%)$ e $\operatorname{TEMED}(0,1 \%)$. Após o preenchimento do tubo com o gel, os mesmos foram cobertos com $20 \mu l$ de água e dejxados polimerizar por no mínimo 2 horas. Antes de iniciar a eletroforese, a água foi removida e a superficie do gel foi seca.

Na primeira dimensão do sistema de equilibrio (IEF/SDS) foi feita uma pré-corrida em direço ao anodo $200 \mathrm{~V}$ por 30 min, $300 \mathrm{~V}$ por $30 \mathrm{~min}$ e $400 \mathrm{~V}$ por $30 \mathrm{~min}$ ) anterior a aplicaço da amostra, para que se estabelecesse o gradiente de pH no gel. Em seguida procedeu-se à aplicaça da amostra previamente dissolvida em tampão de amostra (uréia 9,5M, Nonidet P-40 2\%, ditiotreitol $10 \mathrm{mM}$ e $2 \%$ de anfolitos, i.e. $1,6 \%$ de anfolitos pH 5-8 e 0,4\% de anfolitos pH 3,5-10, da Pharmacial. Sobre a amostra foram adicionados $20 u l$ da solução de cobertura curéia 6M, Nonidet P-40 2\%, ditiotreitol $10 \mathrm{mM}$ e $2 \%$ de anfolitos, ou seja, pH 3,5-10 e pH 5-8 numa razão de 1:4). Finalmente, o tubo foi preenchido 
com $\mathrm{NaOH}$ 0,02M. A camara superior da cuba de eletroforese foi preenchida com NaOH $0,02 M$ e a inferior com $\mathrm{H}_{3} \mathrm{PO}_{4} 0,01 M$. A eletroforese foi feita a temperatura ambiente por 17 horas a 400 Volts. Com a combinaçăo de anfolitos usada $(3,5-10$ e 5-8 numa razăo de 1:4) obtivemos géis com pHs na faixa de 5 a 8 .

A primeira dimensă do sistema de năo-equilibrio (NEPHGE/SDS) envolveu uma corrida eletroforética de curta duraçăo ( 5 horas) a 400 Volts, em direçăo ao catodo, imediatamente após a aplicaça da amostra dissolvida previamente no tamparo da amostra (uréia 9,5M, Nonidet P-40 2\%, ditiotreitol $10 \mathrm{mM}$ e $2 \%$ de anfolitos $\mathrm{pH} 3,5-10$ ). Sobre a amostra foram adicionados $20 \mu l$ da soluça de cobertura (uréia 6M, Nonidet P-40 2\%, ditiotreitol $10 \mathrm{mM}$ e $2 \%$ de anfolitos pH $3,5-10)$ e o tubo foi preenchido com $\mathrm{H}_{3} \mathrm{PO}_{4}$ $0,01 M$. A camara superior da cuba de eletroforese foi preenchida com $\mathrm{H}_{3} \mathrm{PO}_{4} 0,01 \mathrm{M}$ e a inferior com $\mathrm{NaOH} 0,02 \mathrm{M}$. Com - Lote de anfolitos que utilizamos obtivemos géis com pHs na faixa de 4,5 a 9,0 .

Tanto para o sistema IEF/SDS como para o NEPHGE/SDS foram usados no máximo $200 \mu g$ de proteína total, em um volume não superior a $60 \mu l$, em cada eletroforese. No caso de proteínas totais isoladas das células, houve necessidade de uma rápida centrifugaçăo da amostra, antes da aplicaço nos géis de 1. dimensăo, para remogăo do material celular insolúvel no tamparo da amostra. 
Após a eletroforese, os géis da primeira dimensăo foram equilibrados por $30 \mathrm{~min}$ em $5 \mathrm{ml}$ de soluçăo O (Tris-HEl 62, 5mM, pH6, 8, SD5 2,3\%, glicerol 10\%, DTT 1mM) e a seguir congelados em gelo seco e armazenados por no máximo uma semana a $-70^{\circ}[$. A medida de $p H$ dos géis foi feita em potenciometro com eletrodo de superficie (Ingold) antes da imersão dos géis em soluçăo 0 .

No dia da eletroforese de segunda dimensão a solução 0 foi renovada e o géis foram equilibrados por mais $30 \mathrm{~min}$. A eletroforese de segunda dimensão foi feita em gel de poliacrilamida $10 \%$ contendo 505 como descrito no item II.6.1., exceto que o gel de separaçăo era de $15 \mathrm{~cm}$ de largura por $12 \mathrm{~cm}$ de altura e $1 \mathrm{~mm}$ de espessura. 0 gel da 1 * dimensão foi selado ao gel da 2* dimensão com a mesma soluça do gel de empilhamento, da qual haviam sido separados $3 \mathrm{ml}$ antes de serem adicionados os agentes polimerizadores (persulfato de amônio e TEMED). Um pequeno pedaço $(0,5 \mathrm{~cm})$ de gel de composiçăo similar ao gel da 1 . dimensăo, contendo os marcadores de peso molecular (albumina de soro bovino, $67 \mathrm{kDa}$, ovoalbumina, $45 \mathrm{kDa}, \mathrm{Ig}, 55 \mathrm{kDa}$ e $25 \mathrm{kDa}$ e lactoglobulina, $18 \mathrm{kDa}$ ), foi selado ao lado do gel da 1. dimensa.

Ds pedaços de gel contendo os marcadores de peso molecular foram feitos da seguinte maneira: os padroses de peso molecular foram adicionados a uma soluçá de gel de 1. dimensăo, que năo continha anfolitos, para a concentraçăo final de $50 \mu g / m l$ e, após a polimerização, o gel foi cortado 
em pedaços de $0,5 \mathrm{~cm}$ e armazenados em 50 lução $0(0,5 \mathrm{ml})$ a $-70^{\circ} \mathrm{C}$. Antes de serem selados ao gel de 2 dimensaro, foram equilibrados em solução p por $20 \mathrm{~min}$, na presença do corante azul de bromofenol.

Após a eletroforese da 2* dimensăo gel foi submetido ao mesmo tratamento descrito para os géis unidimensionais no item II.6.1. Em alguns experimentos os géis bidimensionais foram corados pelo método da prata (Wray et al., 1981); este método de coloração é muito mais sensivel que a coloração com azul de Coomassie.

Para análise da variação de sintese de proteinas através da incorporaçăo "in vivo" de lass/metionina e posterior separação destas proteínas marcadas em eletroforese bidimensional, foram seguidas as recomendaçós de Alton e Lodish (1977). Nos géis foram colocadas quantidades equivalentes de proteinas e o tempo de exposiça do gel a filme de Raios-X foi calculado de acordo com a incorporaçăo de 1355/metionina em proteinas durante o pulso administrado, de modo que a exposiça fosse a mesma para todas as amostras $\left(1 \times 10^{\circ} \mathrm{cpm}\right.$ colocados no gel equivalem a 24 horas de exposiçăo a $-70^{\circ}[)$. Além disso, foram feitos vários auto-radiogramas para um mesmo gel, variando-se o tempo de exposiçăo, para se ter certeza sobre a variação na velocidade de síntese de uma determinada proteína.

No caso de proteinas marcadas radioativamente com $32 P$, - gel, após a coloração com azul de Coomassie, foi mergulhado em TCA $16 \%, \mathrm{NaHPO}_{4} 50 \mathrm{mM}$ e aquecido a $95^{\circ} \mathrm{C}$ por 40 
min; este tratamento promove a eliminaça de contaminantes do tipo RNA ou polifosfatos (Desmarquets et al., 1984). Após a secagem, o gel foi exposto a filme de Raios-X com intensificadores (ronex Quanta II (da Dupont).

7. Procedimento para obtença de mapa peptidico da Hsp 70

A região do gel bidimensional (IEF/5DS) onde se Localiza a proteína Hsp 70 de germes que sofreram choque térmico e a proteína de $70 \mathrm{kDa}$ de células esporulantes (ambas marcadas "in vivo" com l3ss/metionina) foi cortada imediatamente após rápida coloraçăoldescoramento do gel. 0 fragmento foi incubado com $0,3 \mu g$ de protease v8 de Staphylococus aureus (da 5 igma) para digestão proteolítica parcial como descrito por [leveland et al. (1977). Ds peptidios foram analisados por eletroforese em gel de poliacrilamida $15 \% / 505$ de $1,5 \mathrm{~mm}$ de espessura e detectados por fluorografia (item II.6.1).

8. Eletroforese de RNA em gel de agarose

D RNA isolado como descrito no item II. 4 foi submetido a eletroforese horizontal em gel de agarase, em condiçoses desnaturantes, para análise da sua integridade ou para sua posterior transferencia para filtras de nitrocelulose e hibridizaçăo com sondas de DNA. 
60 .

A eletroforese foi feita em gel de agarose $(20 \mathrm{~cm}$ de comprimento por $14 \mathrm{~cm}$ de (argura e $0,6 \mathrm{~cm}$ de espessura) como descrito por Maniatis et al., 1982. A mistura do gel continha agarose $1,5 \%$, formaldeido $2,8 \%$ e brometo de etidio $0,5 \mu \mathrm{g} / \mathrm{ml}$ dissolvidos em tampăo de eletroforese de RNA (MOPS $20 \mathrm{mM}, \mathrm{pH} 7$, acetato de sódio $5 \mathrm{mM}$, EDTA $0,1 \mathrm{mM})$. O RNA (20ug de RNA total ou $2,5 \mu \mathrm{g}$ de RNA poli(A)+) foi ressupenso em $20 u l$ do tamparo de eletroforese de RNA contendo formaldeido $6 \%$ e formamida $50 \%$ e aquecido a $65^{\circ} \mathrm{C}$ por $10 \mathrm{~min}$, e em seguida resfriado a $4^{\circ} \mathrm{C}$. A essa soluçăo contendo RNA, foram adicionados $2 \mu l$ da seguinte soluçăo: glicerol $50 \%$, EDTA $1 \mathrm{mM}$, azul de bromofenol $0,4 \%$. Após a aplicaçă da amostra iniciamos a eletroforese em direção ao anodo por 16 horas a 30 Volts. Após a eletroforese o gel foi lavado algumas vezes com água e examinado com luz ultra-violeta para visualizaçao das bandas correspondentes aos RNA ribossomais 255 e 185 (Lovett, 1975).

\section{Transferencia do RNA para filtros de nitrocelulose e} hibridização RNA/DNA

Após a eletroforese em gel de agarose a RNA foi transferido para filtro de nitrocelulose CGene Screen, da New England Nuclear), como descrito por Southern (1975). D tampão de transferência usado foi $55[10$ vezes concentrado (a composiçăo de $55[$ é Na[L 0,15M e citrato de sódio 0,015M, $p H 7)$. Em seguida, o filtro foi incubado em soluça de 
hibridizaçăo - $55[6$ vezes concentrado, soluço de Denhardt 5 vezes concentrada (albumina de sorobovino $1 \mathrm{mg} / \mathrm{ml}$, Ficall $1 \mathrm{mg} / \mathrm{ml}$ e polivinilpirrolidona $1 \mathrm{mg} / \mathrm{ml}$ ), SDS 0,5\%, DNA de timo bovino $100 \mu \mathrm{g} / \mathrm{ml}$, EDTA $0,01 \mathrm{M}$ - por 2 horas a 600 C. Esta soluçă foi removida e o filtrofoi entăo incubado, por 16 horas a $60^{\circ} \mathrm{C}$, em soluçă de hibridizaçăo contendo a sonda de DNA desnaturada e radioativamente marcada com $32 P$. A seguir - filtrofoi lavado com quatro trocas de $55[4$ vezes concentrado contendo 5050,18 por um total de 2 horas, a $60^{\circ} \mathrm{C}$. Após secagem à temperatura ambiente o filtro foi exposto a filme de Raios-X, a $-70^{\circ}[$, com o uso de intensificadores [ronex Quanta II (da Dupont).

Como sonda de DNA foi utilizado o plasmideo B8 (Ingolia et al., 1980). Este plasmídeo, gentilmente cedido pela Dra. E. Craig, corresponde ao vetor pBR322 contendo uma única cópia do gene hsp70 de Drosophila inserido no sítio de restriça para a enzima BamHI. O plasmideo B8 foi radioativamente marcado com $32 p$ pela reaça de " nicktranslation" (Maniatis et al., 1982) obtendo-se uma atividade especifica maior que $10>\mathrm{cpm} / \mu \mathrm{g}$ de DNA. 0 |azzP/dATP utilizado na reaça de "nick-translation" foi preparado como descrito por Maia et al., 1984.

10. Ensaio de imunoprecipitaçăo

A reaçăo de imunoprecipitaçăo foi feita como descrito por Gomes e Shapiro (1984) com modificações. Hs células ( $6 \times 10^{\circ}$ zoosporângios ou $4 \times 10^{\circ}$ germes) marcadas com 
lass/metionina foram lisadas por sonicacao (microtip, potência $n^{0} 3,30$ segundos por duas vezes) em $0,5 \mathrm{ml}$ de tampão de lavagem (Tris-HCL 0,05M, pH8,3, Na[L 0,45M, Triton X-100 $0,5 \%$, sendo que o Triton $x-100$ é adicionado imediatamente após a sonicaçăo) contendo puromicina $0,5 \mathrm{mM}$, antipaina $50 \mu g / m L$ e PMSF $1 \mathrm{mM}$ e, em seguida, centrifugadas a $12000 \times \mathrm{g}$ por $5 \mathrm{~min}$. Ho sobrenadante foram adicionados $25 \mu l$ de células "Staph A" ccélulas de Staphylococcus aureus fixadas com formol, da Bethesda Research Laborataries) suspensas em tampão de lavagem contendo albumina de soro bovino ( $1 \mathrm{mg} / \mathrm{ml}$ ). Após 30 min de incubaçăo no gelo, foi feita uma centrifugaça $(12000 \times g, 1 \mathrm{~min})$ para remogå do material particulado e adsorvido inespecificamente. Ho sobrenadante foi adicionado o antisoro contra a proteina Dnak de Escherichia coli na diluiça $1: 250$ (o antisoro nos foi cedido pelo Dr. [.P. Georgopoulos) e a mistura foi mantida no gelo por 2 horas. A precipitaça do complexo antígenoanticorpo foi feita pela adição de $25 \mu l$ de células " 5 taph A* Após $30 \mathrm{~min}$ de incubaça no gelo, o complexo ligado a "Staph A" foi coletado por centrifugaça. As células foram lavadas 3 vezes com tampa de lavagem e coletadas por centrifugação. 0 precipitado foi suspenso em tampăo de amostra para eletroforese unidimensional, fervido por 3 min e, em seguida, centrifugado. o sobrenadante foi enta submetido à eletroforese em gel de poliacrilamidalsDS. 
63.

11. Deteç̧a imunológica de proteinas imobilizadas em filtros de nitrocelulose ("immunoblotting")

11.1. Transferência eletroforética de proteínas de géis de poliacrilamida para filtros de nitrocelulose

Após separaçăo das proteínas por eletroforese uni ou bidimensional em gel de poliacrilamida/sDs, as mesmas foram submetidas a transferencia eletroforética para filtro de nitrocelulose como descrito por Towbin et al. (1979) e Burnette (1981). A transferência foi feita a $200 \mathrm{~mA}$ ( 45 Volts), por 20 horas a $4^{\circ}[$, utilizando-se o seguinte tamparo: Tris-base $25 \mathrm{mM}$, glicina $196 \mathrm{mM}$, metanol $20 \%$. Após o término da transferéncia o filtro de nitrocelulose ("blot") foi corado por $5 \mathrm{~min}$ com solução de Ponceau-5 0,1\% em ácido acético $10 \%$ e em seguida descorado com água bidestilada.

11.2. Detecção imunológica das proteinas do "blot"

Após transferência, coloração e descoramento, a regiăo do filtro de nitrocelulose que contém os marcadores de peso molecular foi cortada e seca ao ambiente. 0 restante do "blot" foi imediatamente incubado por 30 min em TBS (TrisHCl $10 \mathrm{mM}, \mathrm{pH} 7,5, \mathrm{Na}[\mathrm{l} 150 \mathrm{mM})$ contendo leite em pó desnatado (Molico) 5\% e $\mathrm{NaN}_{3}$ 0,05\%, para saturaçăo de sítios inespecíficos de ligaçăo. Em seguida ofiltro foi incubado em outra porção desta mesma soluçăo contendo o anticorpo 
apropríado na diluição 1:500, por 14 horas, à temperatura ambiente, sob agitação branda. Foram usados os seguintes anticorpos monoclonais (da Amersham) feitos em camundongo: anti-actina (contra actina de músculo esquelético de galinha), anti-a-tubulina e anti- $\beta$-tubulina (contra a e $\beta$ tubulinas de microtúbulas de cérebra de galinha). Após a incubaçăo com os anticorpos, os "blots" foram lavados com TBS por 30 min com várias trocas para a remoçá dos anticorpos não ligados.

Para revelação do complexo antígeno-anticorpo utilizamos um método de deteç̧a imunoenzimática, através de anticorpos conjugados à enzima peroxidase (Towbin et al., 1979). Hssim, após a incubação com os anticorpos monoclonais, o "blot" foi incubado com um segundo anticorpo anti-igg de camundongo (da Cappell) desenvolvido em coelho (diluiçăo 1:500). Após 60 min de incubaçăo, o filtro foi Lavado com TBS por $30 \mathrm{~min}$ e em seguida incubado por $60 \mathrm{~min}$ com o conjugado imunoenzimático canti-IgG de coelho conjugado com peroxidase) na diluiçăo 1:500. Após lavagem do filtrocam TBS por $30 \mathrm{~min}$ foi feita a reaça enzimática usando-se diaminobenzidina $\quad\left(0,5 \mathrm{mg} / \mathrm{mL}\right.$ em $\mathrm{Na}_{2} \mathrm{HPO}_{4} \quad 8,0 \mathrm{mM} /$ $\mathrm{KH}_{2} \mathrm{Pl} 41,5 \mathrm{mM} \quad \mathrm{pH} 7, \mathrm{~K}\left[\mathrm{l} 2,7 \mathrm{mM}, \mathrm{Na}[\mathrm{l} 137 \mathrm{mM})\right.$ e $\mathrm{H}_{2} \mathrm{O}_{2}(1 \mu \mathrm{L} / \mathrm{ml}$ de uma soluça 30\%). A banda correspondente ao complexo antigeno-anticurpo desenvolveu cor marrom em 5-10min. A reaçăo foi interrompida pela adiça de $\mathrm{H}_{2} \mathrm{O}$ destilada. O filtrofoi então lavado várias vezes em água e seco ao 
ambiente ou submetido imediatamente à reaça com outro anticorpo em alguns casos.

Em alguns experimentos as proteínas do "blot" estavam marcadas com |3ss/metionina. Neste caso, após a revelaçăo do complexo imunoenzimático, ofiltro foi tratado por $30 \mathrm{~min}$ com reagente fluorográfico Amplify (da Amersham), seco ao ambiente e exposto a filme de Raios-X, a $-70^{\circ} \mathrm{C}$.

Também foi utilizado o anticorpo monoclonal anti-Hsp70, na diluição 1:500, (contra a proteína Hsp70 de Drosophila) desenvolvido em rato. Como segundo anticorpo utilizou-se anti-IgG de rato, desenvolvido em coelho, procedendo-se em seguida à revelação do complexo antígeno-anticorpo com o conjugado imunoenzimático, como descrito acima. Os anticorpos anti-Hsp70 e anti-IgG de rato nos foram gentilmente cedidos pelos Drs. 5. Lindquist e J.D. Lopes, respectivamente.

o conjugado imunoenzimático que utilizamos correspondia a fraça IgG dos soros de carneiros (anti-IgG de coelho) que foi acoplada com peroxidase pelo métado descrito por Nakane e Kawai (1974) e nos foi gentilmente cedido por Glaucia 5. Paranhos.

12. Purificasao de tubulina de flagelo de zoósporos

D isolamento de microtúbulos de flagelo de zoósporos para a obtençao de tubulina foi feito como descrito por Abe e Lovett (1982) e Kowit e Fulton (1974). Ds zoósporos 
66 .

obtidos após a esporulação de células crescidas em meio PYG-P (ítem II.1.2.) foram ressusspensos em Tris-HCl 25mM, pH7,5 na concentraçăo de $4 \times 10$ zoósporos $/ \mathrm{ml}$ e desflagelados através de vigorosa agitaçăo (Vortex, 20 segundos por duas vezes). A suspensão de zoósporos e flagelos foi centrifugada a $755 \times g$ por 2,5 min $\left(4^{\circ}[)\right.$ e, em seguida, o sobrenadante contendo apenas os $f$ lagelos foi centrifugado a $12000 \times g$ por 10 min. Oprecipitado contendo os $f$ lagelos foi ressuspenso em $0,5 \mathrm{ml}$ de lauril sarcosinato de sódio 0,075\%, Tris-HCL $38 \mathrm{mM}$ pH7,G e EDTA $0,3 \mathrm{mM}$ e, após incubaçă por $30 \mathrm{~min}$ a $4^{\circ} \mathrm{C}$, foi centrifugado a $100000 \times g$ por $30 \mathrm{~min}$. Este tratamento com detergente rompe as membranas flagelares, Liberando os microtúbulos. D precipitado obtido foi ressuspenso em $0,3 \mathrm{ml}$ de tampão B (Tris-HCL 25mM pH7,6, DTT 0,1mM, EGTA 0,1mM, GTP $0,1 \mathrm{mM}$ ) adicionando-se em seguida $0,3 \mathrm{ml}$ de um tamparo contendo lauril sarcosinato de sódio $0,3 \%$, Tris-HCl $25 \mathrm{mM}, \mathrm{pH}, 6,6$, DTT $0,1 \mathrm{mM}$ e EQTA $0,4 \mathrm{mM}$. Após incubaçăo a $4^{\circ} \mathrm{L}$ por $30 \mathrm{~min}$ a suspensão foi centrifugada a $27000 \times g$ por $25 \mathrm{~min}$. precipitado foi ressuspenso em $0,1 \mathrm{ml}$ do tamparo $B$ e as proteinas foram precipitadas pela adiço de $8 \mathrm{ml}$ de acetona gelada e centrifugaça a $12000 \times g$ por 10 min. O precipitado após lavagem com acetona e secagem a vácuo foi ressuspenso em tampáo de eletroforese bidimensional (O'Farrell, 1975). A eletroforese no sistema IEF/SDS (item II.6.2) permitiu a visualizaçăo, após coloraçăo do gel com azul de Coomassie, de duas bandas majoritárias de 56 e 55 kDa de peso molecular 
sendo a banda de $55 \mathrm{kDa}$ predominante e ligeiramente mais ácida.

13. Separaça dos derivados fosforilados da proteina ribossomal 56

13.1. Extração de proteinas ribossomais

0 sedimento de células congeladas $(5 \times 10)$ células esporulantes ou 4-5x10e germes) obtidas como descrito nos itens II. 1.3 e 1.4, foi descongelado na presença de $1,5 \mathrm{ml}$ de tampão de lise contendo tampão fosfato de sódio $50 \mathrm{mM}, \mathrm{pH} 7$, NaF $50 \mathrm{mM}, \mathrm{KCl} 250 \mathrm{mM}$, DTT $1 \mathrm{mM}$ e PMSF $0,15 \mathrm{mg} / \mathrm{ml}$, para evitar a desfosforilaçăo da proteína 56 (Bonato et al., 1984). A seguir, foram lisadas pela passagem em "French Press" por 3 vezes seguidas à pressão de 400 psi. Os extratos foram imediatamente centrifugados a $12000 \times 9$, por $10 \mathrm{~min}, 4^{\circ} \mathrm{C}$, para eliminação de células não rompidas e restos de parede celular. Ho sobrenadante foi adicionado Mgclz para concentraçăo final de 3mM. Ds ribossomos aí presentes foram sedimentados a $39000 \mathrm{rpm}$ por $90 \mathrm{~min}$ em rotor 5pinco 50Ti.

Em seguida as proteinas ribossomais foram extraidas com ácido acético como descrito por Hardy et al. (1969). D precipitado contendo os ribossomos foi ressuspenso em $150 \mu$ l de $\mathrm{MgCl}=0,2 M$, adicionando-se imediatamente 2 volumes de ácido acético vagarosamente, sob agitaça. Após $45 \mathrm{~min}$ a $4^{\circ}[$, sob agitação, a suspensăo foi centrifugada a $12000 \times g$ 
68.

por $15 \mathrm{~min}$. Ro sobrenadante foram adicionados 5 volumes de acetona fria e após precipitaçă a $-20^{\circ} \mathrm{C}$, por uma noite, as proteínas ribossomais foram coletadas por centrifugaça a $4000 \times g$ por $10 \mathrm{~min}$. D precipitado obtido foi lavado com acetona, seco a vácuo durante 5 min e armazenado a $-20^{\circ} \mathrm{C}$.

\subsection{Eletroforese bidimensional para separaçăo dos} derivados fosforilados de 56

Para a visualizaça das subespécies fosforiladas da proteina ribossomal 56 utilizamos o sistema eletroforético bidimensional básicolácido (Lastick e McLonkey, 1976) como descrito por Bonato et al. (1984, 1985). Este sistema eletroforético separa os diferentes derivados fosforilados de acordo com o número de fosfatos de cada derivado (Gressmer e Wool, 1974), sendo que quanto maior o nível de fosforilaçăo, menor a migraçăo eletroforética do derivado.

As proteinas ribossomais purificadas ( $300 \mu g$ ) foram dissolvidas em $60 \mu l$ de un tamparo contendo uréia $10 \mathrm{M}$, Tris/borato $20 \mathrm{mM}$, pH8,6, EDTA $1 \mathrm{mM}$, ditiotreitol $15 \mathrm{mM}$ e aquecidas a $60^{\circ} \mathrm{C}$, por $10 \mathrm{~min}$, antes da aplicaça ao gel da primeira dimensão.

Para a primeira dimensa foram usados tubos de vidro (130 $\times 3 \mathrm{~mm}$ de diâmetro) preenchidos até a altura de $115 \mathrm{~mm}$ com gel de separaçăo (Trislborato $200 \mathrm{mM}$, pH8,6, acrilamida $4 \%$, bisacrilamida $0,1 \%$, uréia $8 M$, EDTA $10 \mathrm{mM}$ ). A eletroforese foi feita en direça ao catodo por 20 horas a 105 volts 
69.

utilizando-se o seguinte tamparo do eletrodo: Trislborato 60mM, pH8,6, EDTA 3mM, 2-mercaptoetilamina 0,02\%. Apos o término da corrida os géis foram armazenados a $-70^{\circ}[$ em soluça de equilibrio (glicinalácido acético $46 \mathrm{mM}$, pH4, uréia 6M, 2-mercaptoetanol 1\%, glicerol 10\%). A separaça das proteinas na segunda dimensarofoi feita em gel com $20 \mathrm{~cm}$ de largura por $15 \mathrm{~cm}$ de altura e $0,1 \mathrm{~cm}$ de espessura contendo: acrilamida $18 \%$, bisacrilamida $0,5 \%$, uréia $6 M$, ácido acético/KOH 0,44M, pH4,5. A corrida foi feita em direçăo ao catodo a 135 volts por 20 horas, utilizando tamparo glicinalácido acético $93 \mathrm{mM}, \mathrm{pH} 4$, contendo 2-mercaptoetilamina $0,02 \%$. Terminada a eletroforese o gel foi corado, descorado e seco como descrito no item II.6.1. 
III. RESULTADOS E DISCUSSAO

1. Análise das variaçós no padrăo de sintese de proteinas totais durante a esporulaça e a germinaça em

Blastocladiella emersonii.

Para investigar a regulaçăo da sintese proteica durante a esporulaçăo e a germinaçăo do fungo Blastocladiella emersonif utilizamos eletroforese bidimensional em gel de poliacrilamida em dois sistemas eletroforéticos (IEF/SDS e NEPHGE/SDS para a análise das proteínas sintetizadas "in vivo", bem como das produtos resultantes da traduçăo "in vitro" dos RNAs mensageiros isolados nos diferentes estágios das duas fases de citodiferenciaça do fungo.

1.1. Sintese de proteinas durante a esporulaça

1.1.1. Qbtençåo das proteínas totais na ausência de proteolise

Para a obtençăo de perfis reprodutiveis de eletroforese bidimensional é necessário que a obtençăo das proteinas totais das células seja feita em completa ausência de proteólise. Sendo conhecido que o zoósporo de B.emersoni i é uma célula rica em proteases (Correa et al., 1978, 1979; Brochetto-Braga et al., 1982; Gomes et al., 1983), utilizamos estas células para estabelecermos uma condiça de 
Lise celular, na qual a proteólise fosse evitada. A figura 1 compara dois métodos de lise de zoósporos que tiveram as suas proteinas marcadas "in vivo" com lass/metionina ao longo de toda a esporulaçăo. No primeiro método, os zoósporos foram centrifugados, congelados e descongelados na presença do tamparo de amostra de eletroforese bidimensional (uréia 9,5M, NP-40 2\%, DTT $10 \mathrm{mM}$, anfolitos 2\%) e, imediatamente, submetidos à eletroforese. No segundo método, as células foram, imediatamente após a centrifugaço, submetidas ao tratamento com TCA 10x descrito no item 2 de Procedimentos Experimentais. Como podemos verificar, os padrốs eletroforéticos obtidos nas duas condiçơs 5 go completamente diferentes. No primeiro método (Fig.1A), obtivemos um perfil eletroforético com um grande número de polipeptidios de baixo peso molecular, quando comparado ao perfil eletroforético obtido com células tratadas com TCA 10\% (Fig.1B), indicando que a proteólise pode ocorrer mesmo na presença de $9,5 M$ de uréia.

Testamos também a lise de zoósporos na presença de MES 20mM, pHG,5, EDTA 1mM, EGTH 1mM, glicerol 10\%, DTT 4mM, PMSF

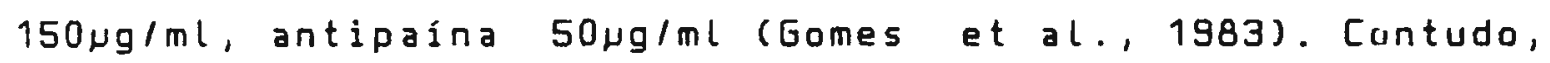
mesmo na presença de inibidores de proteblise, os perfis eletroforéticos obtidos nå foram reprodutiveis cresultado nă mostrado).

o tratamento com TCA foi, portanto, a condicgo de escolha, por evitar a proteólise, além de permitir a sonicaça das células, uma vez que os demais fenótipos 

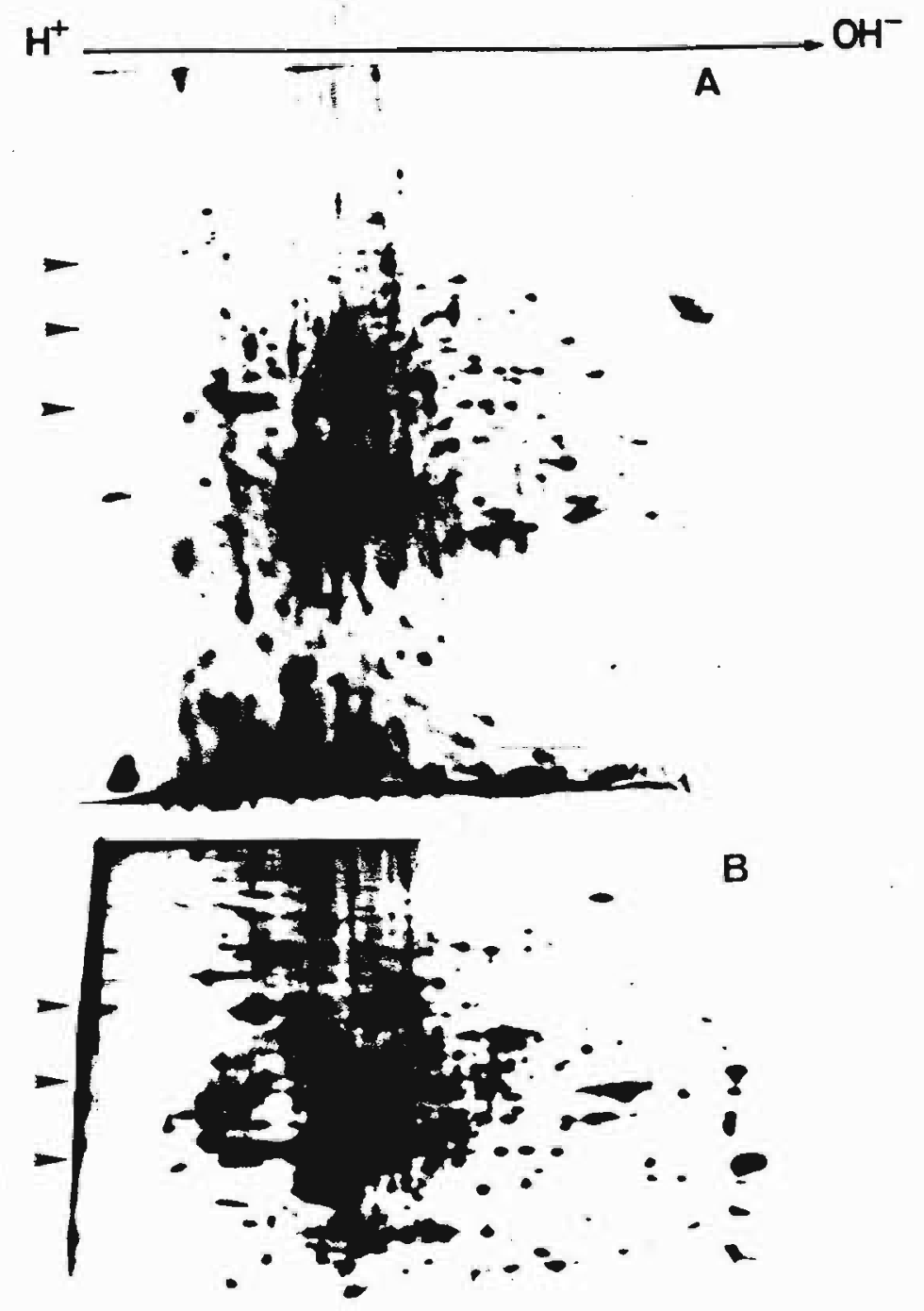

B

Figura 1 - Eletroforese bidimensional (NEPHGE/SDS) de proteinas totais isoladas de zoósporos. As células foram marcadas com las5/metionina ao longo da esporulação e os zoósporos obtidos foram congelados e descongelados na presença de tamparo de eletroforese bidimensional ( $A$ ) ou imediatamente precipitados com TCA como descrito em Procedimentos Experimentais (B). As setas à esquerda (lado ácido dos auto-radiogramas) representam os marcadores de peso molecular (67,55, $45 \mathrm{kDa}$, de cima para baixo). 
celulares de B.emersonii possuem parede celular e năo lisam pelo simples congelamento e descongelamento.

\subsubsection{Padrăo das proteínas sintetizadas "in vivo"}

Durante a esporulaço foram administrados pulsos consecutivos de 30 minutos com lass/metionina, sendo que após cada pulso as células foram coletadas por centrifugacgo e, imediatamente, submetidas ao tratamento com Tch 10\%. Após extraça as proteínas for am analisadas em eletroforese bidimensional em gel de poliacrilamida no sistema de equilibrio, IEF/SDS (D'farrell, 1975) que detecta proteinas com $p I$ entre 5,5 e 8,0 e no sistema de năo equilibrio, NEPHGE/SDS (D'Farrell et al., 1977), que detecta além das proteinas ácidas, as proteínas mais básicas (pI entre 4,5 e $9,0)$.

A análise da variaça da velocidade de síntese das proteínas ao longo da esporulaçăo foi feita pela comparaço dos géis das proteínas sintetizadas em cada momento (pulso) da esporulaçăo. A identificaça das proteinas nos vários auto-radiogramas foi feita através do pI e do peso molecular relativo dessas proteinas, e também através da superposiço de desenhos correspondentes aos auto-radiogramas. Foram realizados dois experimentos idênticos, sendo que, da comparaçăo de ambos, pudemos definir as variaçóas que ocorrem no padra de síntese das proteínas totais ao longo da esporulação. Um total de 400 polipeptidios foram 
detectados no sistema IEF/SDS e a sintese de 85 foi analisada. A síntese dos polipeptídios basicos foi analisada no sistema NEPHGE/SDS e um total de 23 polipeptídios puderam ser inequivocamente identificados na porçăo mais básica do gel.

As figuras 2 e 3 mostram os perfis eletroforéticos obtidos quando as proteínas sintetizadas nos diferentes estágios da esporulação foram analisadas, respectivamente, nos sistemas IEF/SDS e NEPHGE/SDS. A comparaçăo dos vários auto-radiogramas revela a ocorrencia de uma extensa variaça na velocidade relativa da síntese de um grande número de proteínas. Já nos 30 min iniciais da esporulaça podemos observar várias mudanças no padrăo de síntese. Quando comparamos o padra das proteinas 5 intetizadas entre 0-30 min ( $F i g .2 B, F i g .3 B)$ com o padrao das proteinas sintetizadas pelas células vegetativas durante os 45 min finais do crescimento (Fig.2A, Fig.3A), podemos notar que a maioria das proteinas sintetizadas durante os 30 min iniciais da esporulaçăo năo foram detectadas entre as proteínas sintetizadas durante o final do crescimento. Algumas das proteinas sintetizadas pelas células vegetativas cpor exemplo: 8, 9, 27, 28, 30, 31) sofreram decréscimo na sua síntese logo no inicio da esporulaça e outras tiveram sua sintese mantida por toda a esporulaça ( 1 a 5 ).

Durante o inicio da esporulaçăo velocidade relativa da sintese de algumas proteínas (por exemplo: 17 a 19, 21 a 26, 30 a 33,86 a 88 ) diminui, enquanto outras proteínas tem 

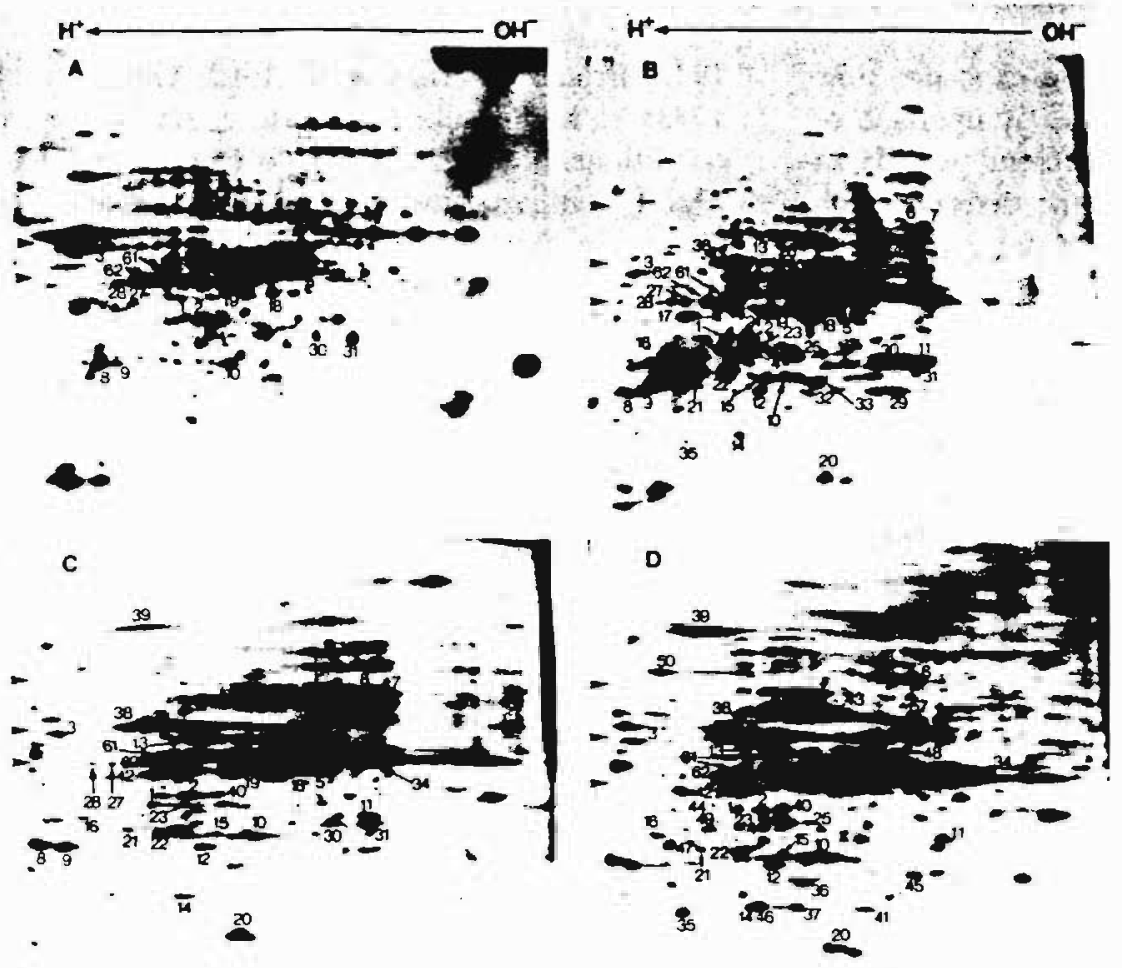

$\therefore$
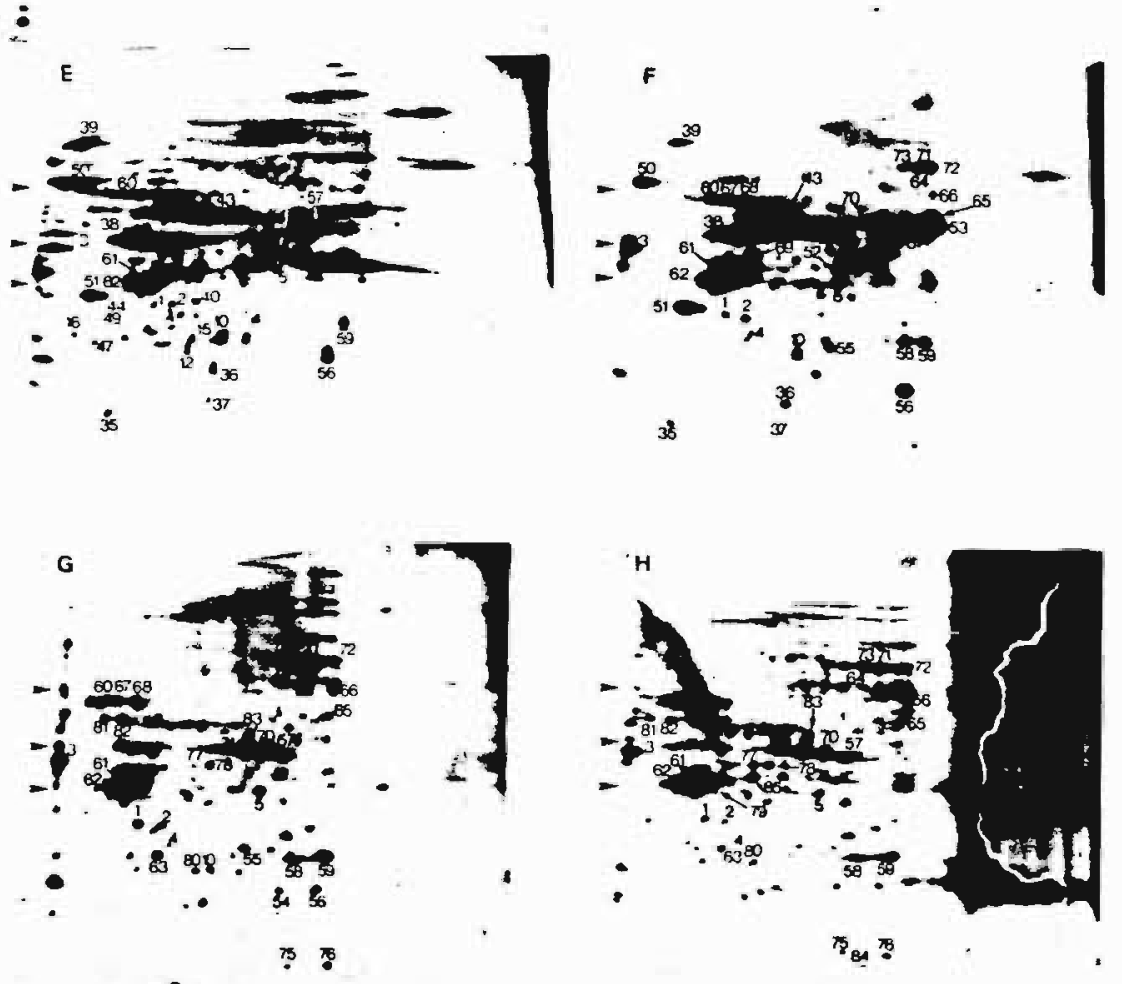
Figura 2 - Eletroforese bidimensional (IEF/SDS) de proteinas sintetizadas durante a esporulação. As células foram marcadas com l3s 5 /metionina por períodos de $30 \mathrm{~min}$, tratadas com TCA e as proteinas totais submetidas à eletroforese. Sao mostrados os auto-radiogramas dos géis correspondentes às proteinas sintetizadas durante o crescimento (A) e nos intervalos $0-30$ (B), 30-60 ( $C$ ), 60-90 (D), 90-120 (E), 120150 (F), $150-180$ (G), $180-210$ (H) min após induça da esporulaçăo. As setas à esquerda (lado ácido dos autoradiogramas) representam os marcadores de peso molecular (67, 55, $45 \mathrm{kDa}$, de cima para baixo). Aos $120 \mathrm{~min}$ mais que 90\% das células apresentavam papila, e aos $240 \mathrm{~min}$ mais que $90 \%$ das células já haviam liberado os zoósporos 

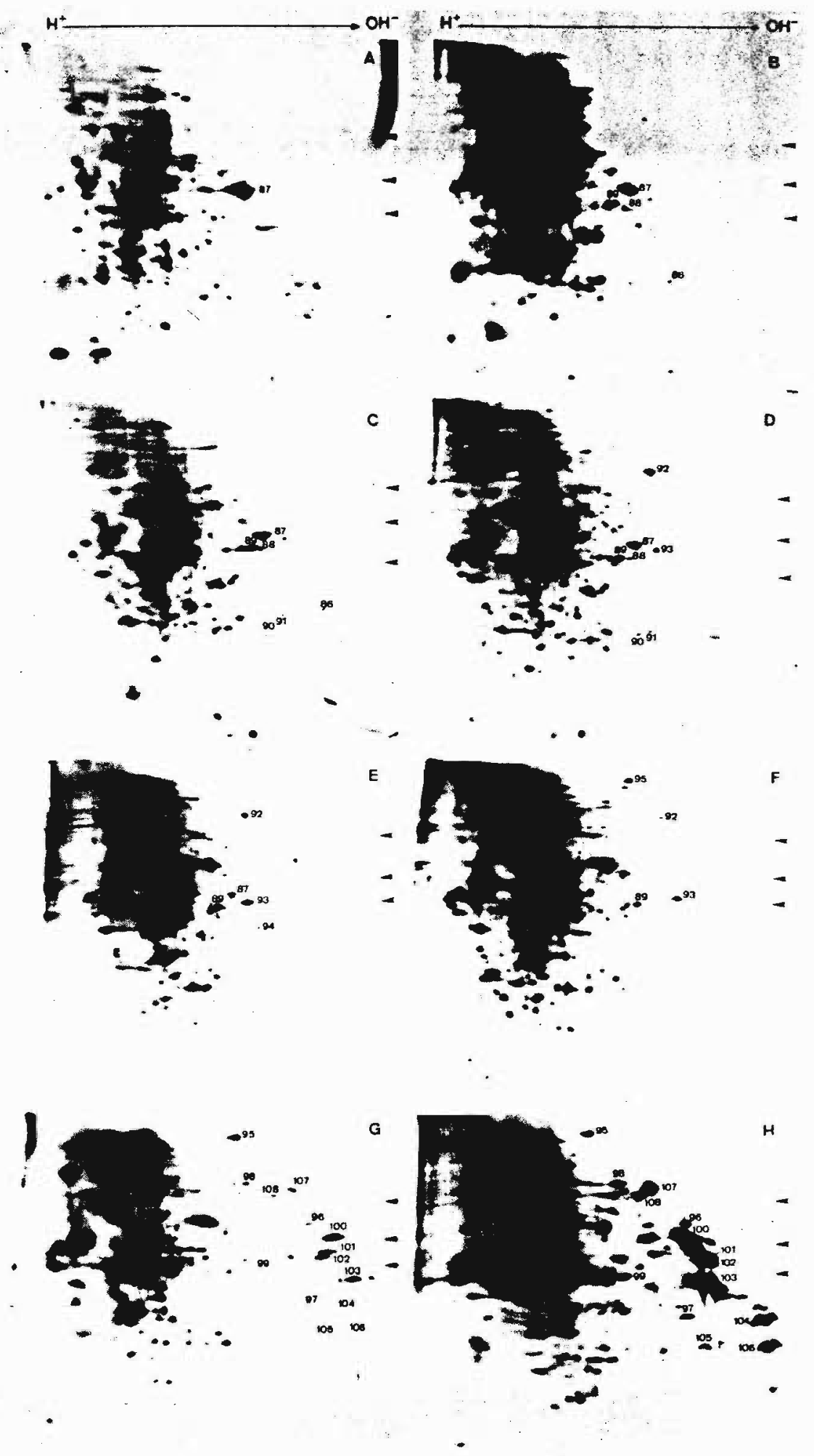

Figura 3 - Eletroforese bidimensional (NEPHGE/SDS) de proteinas sintetizadas durante a esporulacao. Como descrito na Figura 2 . 
sua velocidade de sintese aumentada coor exemplo: 34, 38, 41, 42, 89). Um certo número de proteínas nåo mostraram variaçăo na sua sintese (por exemplo: 1-5) e, provavelmente, correspondem à proteínas indispensáveis à manutençăo da célula.

Uma correlaçăo entre o aumento da síntese de algumas proteínas com a sucessaro de eventos morfológicos que ocorrem na esporulaçăo pode ser feita. Assim, o aumento da síntese das proteinas no: $34,41,42,45,46,90,91$ coincide com o aparecimento do septo basal do zoosporângio (60-90 min) e das proteínas no= 44, 50,92, 93, 94 coincide com a formaça da papila (120 min). A partir dos 150 min de esporulaça ocorrem mudanças profundas no padra de sintese proteica, o que coincide com a fase de diferenciagro dos zoósporos. A maioria dessas proteinas săo proteínas básicas (96 a 108), que são sintetizadas exclusivamente na esporulaçăo mais tardia (Fig. $3 H$ ).

D quadro apresentado na figura 4 esquematiza a variaça da sintese dos polipeptídios analisados pela comparaça dos perfis eletroforéticos bidimensionais das figuras 2 e 3 .

Com o objetivo de detectar alteraçóses no acúmulo em massa das proteinas durante a esporulação, géis bidimensionais foram submetidos à coloraça pela prata (Wray et al., 1981). Este método de coloração é muito mais sensivel que a coloraçăo com azul de Coomassie; contudo, como esta coloraça interfere na fluorografia (Morrissey, 1981), foram necessárias corridas eletroforéticas 


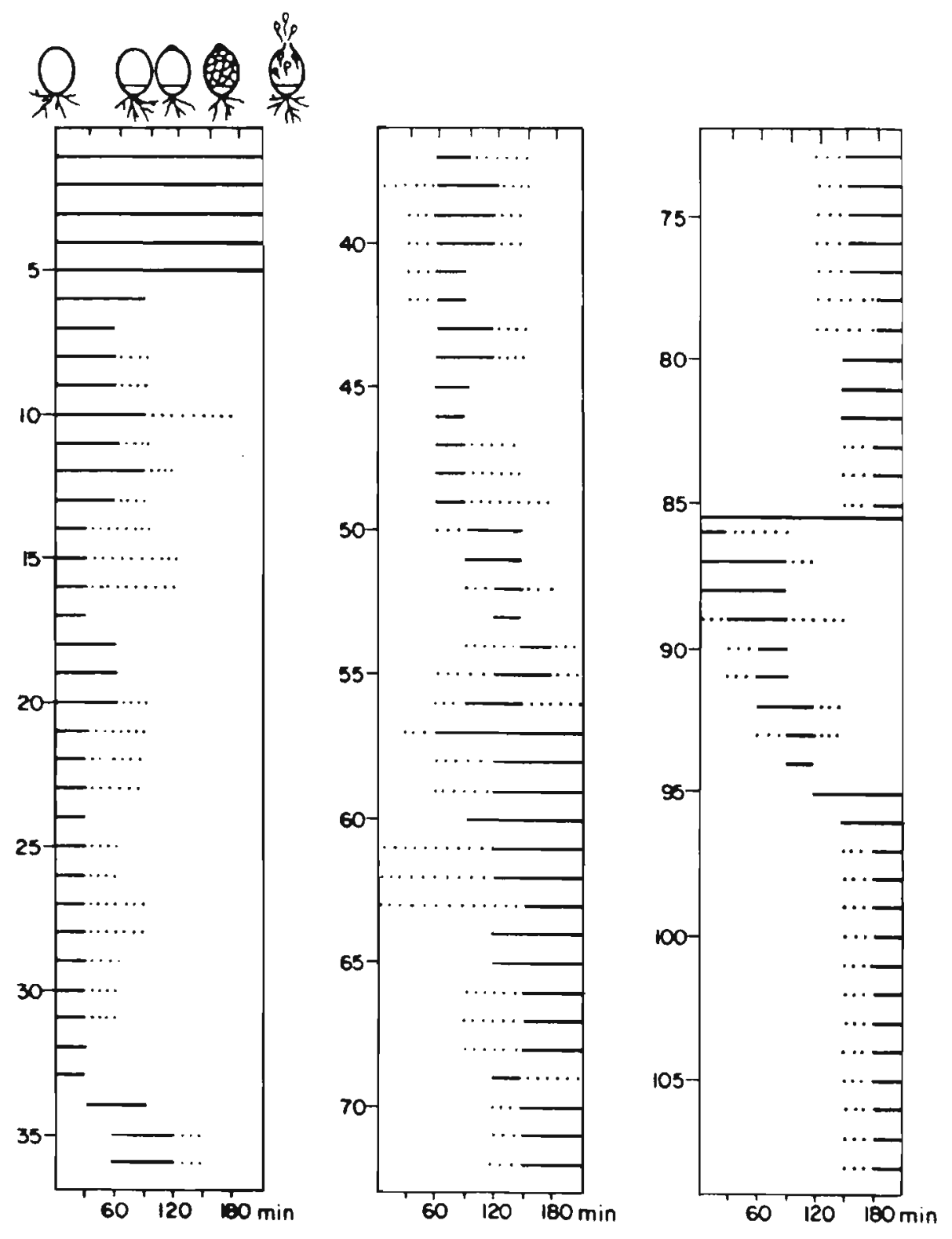

Figura 4 - Duadro esquemático da variação da síntese das proteínas durante a esporulaça. Os números nas laterais ( 1 a 85) correspondem às proteínas analisadas como descrito na Figura 2 (IEF/SDS) e os números (86-108) correspondem as proteínas analisadas como descrito na Figura 3 (NEPHGE/SDS). Linha sólida indica síntese máxima, linha descontínua indica síntese e ausencia de linha indica que nenhuma sintese foi detectada. 
independentes para as amostras que foram analisadas pelos dois métodos, fluorografia e coloraça pela prata.

Os eletroferogramas corados pela prata, mostrados nas Figs. 5 e 6, săo relativos às proteínas isoladas de células vegetativas, zoosporângios de 50,120 e $180 \mathrm{~min}$ e de zoósporos, que foram analisadas nos dois sistemas eletroforéticos IEF/SDS e NEPHGE/SOS, respectivamente. A comparação destes eletroferogramas revelou pouquíssima variaçăo no padrăo de proteinas lotais acumuladas durante toda a esporulaçăo, ao contrário da enorme variaçăo que foi verificada no padra de sintese de proteinas. Muitas das proteinas intensamente marcadas com lasslmetionina cpor exemplo $11,25,58,59,68, F i g .2)$, e inclusive aquelas proteínas básicas ( 96 a 108, Fig.3), năo foram detectadas nas géis corados pela prata e, provavelmente, correspondem a proteinas cujo conteúdo é minoritário em relação a quantidade de proteína total da célula.

No entanto, algumas proteínas sintetizadas durante a esporulação puderam ser identificadas nos eletroferogramas corados pela prata. Embora a velocidade relativa da sintese de alguns destes polipeptídios apresentasse variaça durante - desenvolvimento, os seus conteúdos em massa permaneceram constantes durante toda a esporulaça, pelo menos dentro da sensibilidade do método de coloraçăo. Por exemplo, a proteína 87, uma proteína básica que é sintetizada pelas células vegetativas e cuja síntese diminui aos 90 min da esporulaçào (Figs.3 e 4), permanece constante em massa 
81.

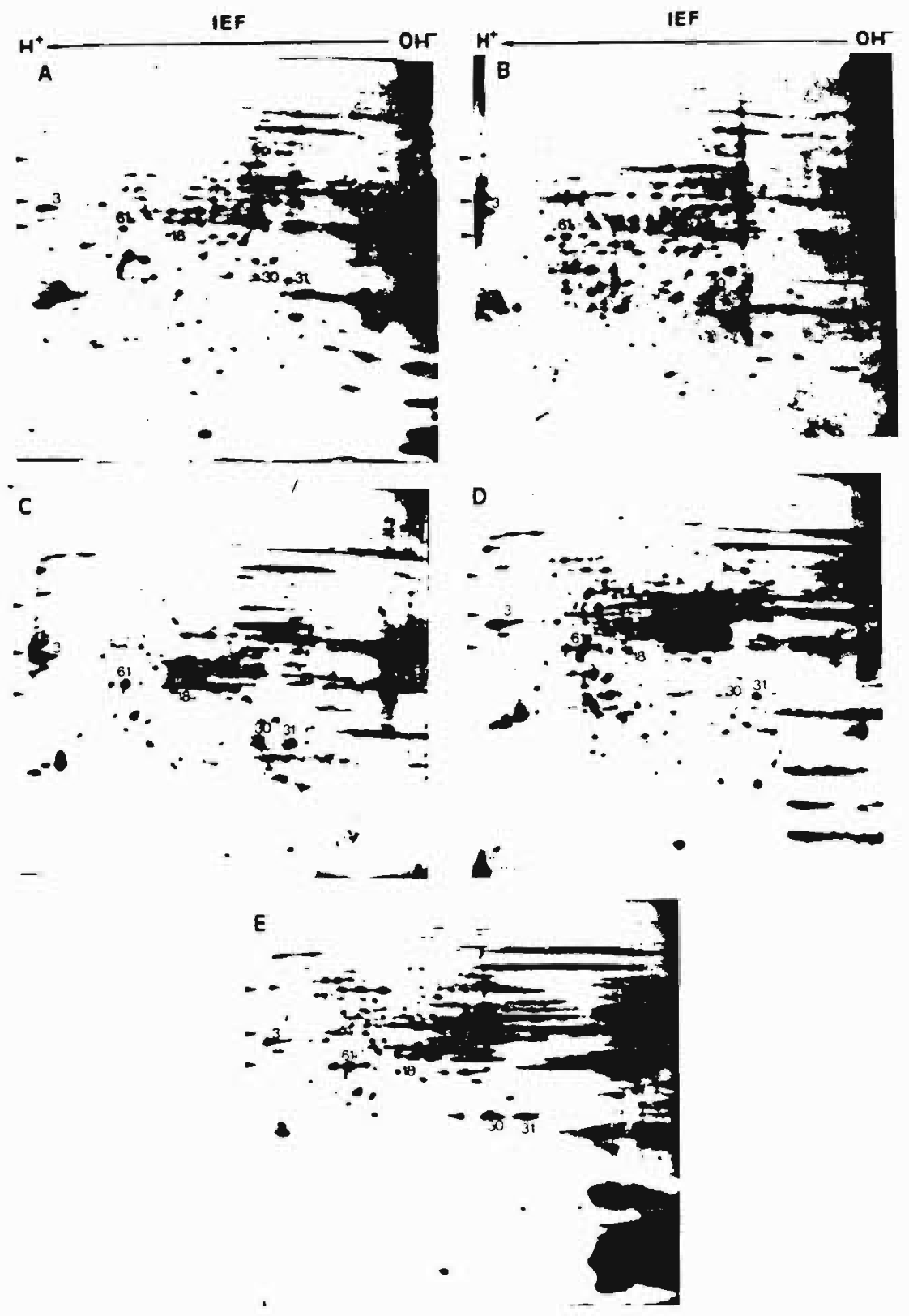

Figura 5 - Géis bidimensionais (IEF/SDS) corados pelo método da prata. Proteinas totais isoladas de células em crescimento (A), células esporulantes de $60 \mathrm{~min}$ (B), $120 \mathrm{~min}$ ([), $180 \mathrm{~min}$ (D) e de zoósporos (E) foram submetidas à eletroforese bidimensional e os géis obtidos foram corados pelo método da prata. As setas à esquerda dos géis representam os marcadores de peso molecular ( $67,55,45 \mathrm{kDa}$, de cima para baixo). As proteínas numeradas correspondem às proteínas sintetizadas "in vivo" e identificadas na Fig.2. 


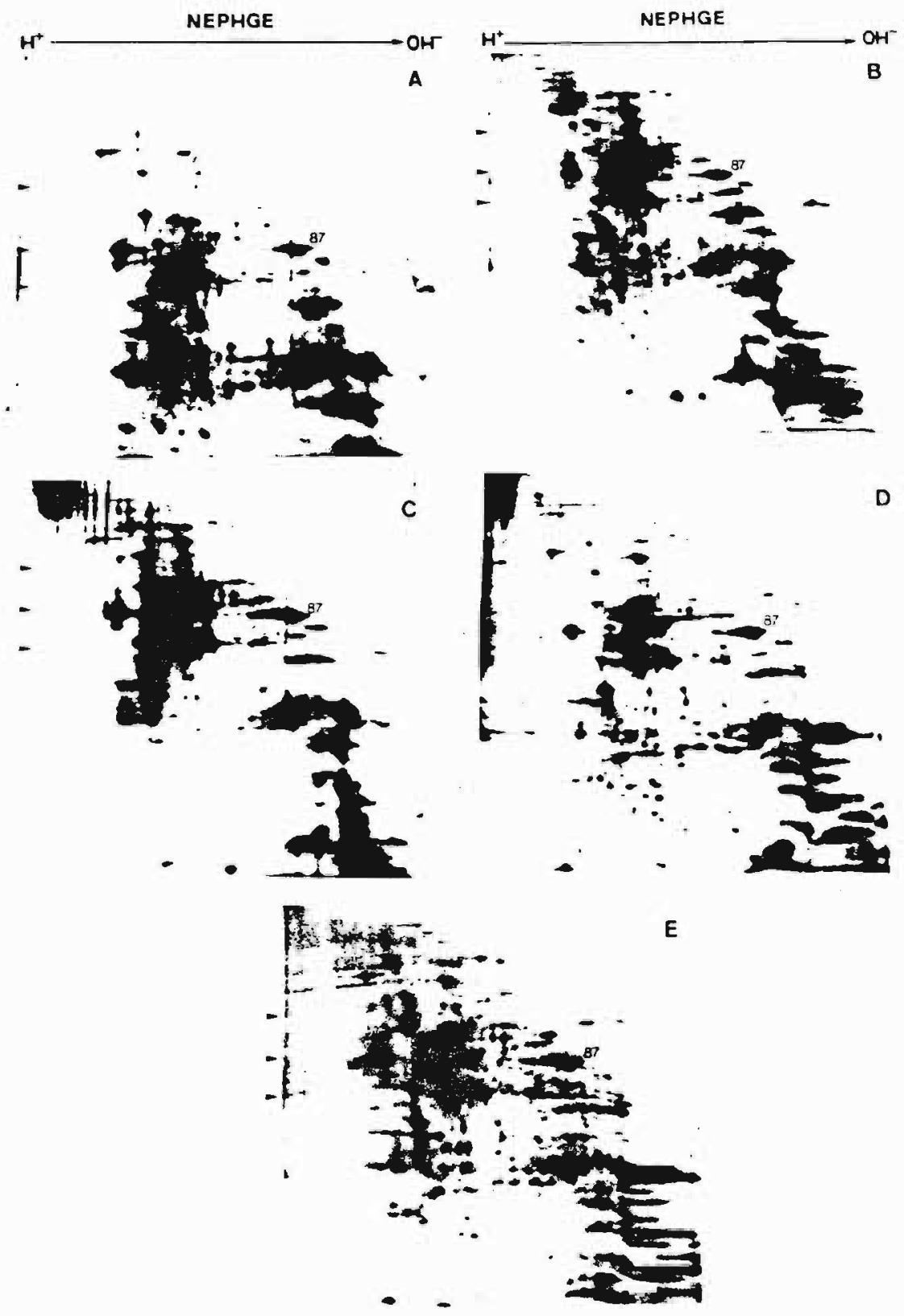

Figura 6 - Géis bidimensionais (NEPHGE/SDS) corados pelo método da prata. Como descrito na figura 5. As proteínas numeradas correspondem às proteínas sintetizadas "in vivo" e identificadas na Fig. 3. 
83.

durante toda a esporulaçăo, sendo mantida inclusive nos zoósporos, o que demonstra sua extrema estabilidade. As proteínas $18, \quad 30$ e 31 åo também proteinas típicas de crescimento (Fig.2A) e embora a velocidade de sua síntese diminua durante a esporulaçăo (Fig.4), săo visualizadas, pela coloraça da prata, entre as proteínas dos zoósporos (Fig.5E).

A proteína 61, uma proteína cuja síntese é controlada pelo desenvolvimento, foi a única proteína cujo aumento de síntese fai correlacionado com um aumento na quantidade em massa. Essa proteína corresponde à actina como será demonstrado no item III.1.3.

\subsubsection{Traduça "in vitro" de RNAs isolados durante a} esporulaça

Ds mRNAs poli(A)+ isolados de células de diferentes estágios da esporulação foram traduzidos em lisado de reticulócitos de coelho. Os produtos resultantes da traduça "in vitro" desses mRNAS poli(A)+ foram separados em eletroforese unidimensional e em eletroforese bidimensional nos sistemas IEF/SDS e NEPHGE/SDS.

D auto-radiograma da eletroforese unidimensional em gel de poliacrilamida, apresentado na Fig.7, mostra os produtos resultantes da traduça "in vitro" de duas concentraçós diferentes $(0,5 \mu g$ e $1,0 \mu g)$ do RNA poli( ()$^{+}$isolado de células vegetativas, células de 60,120 e 180 min de 
84.

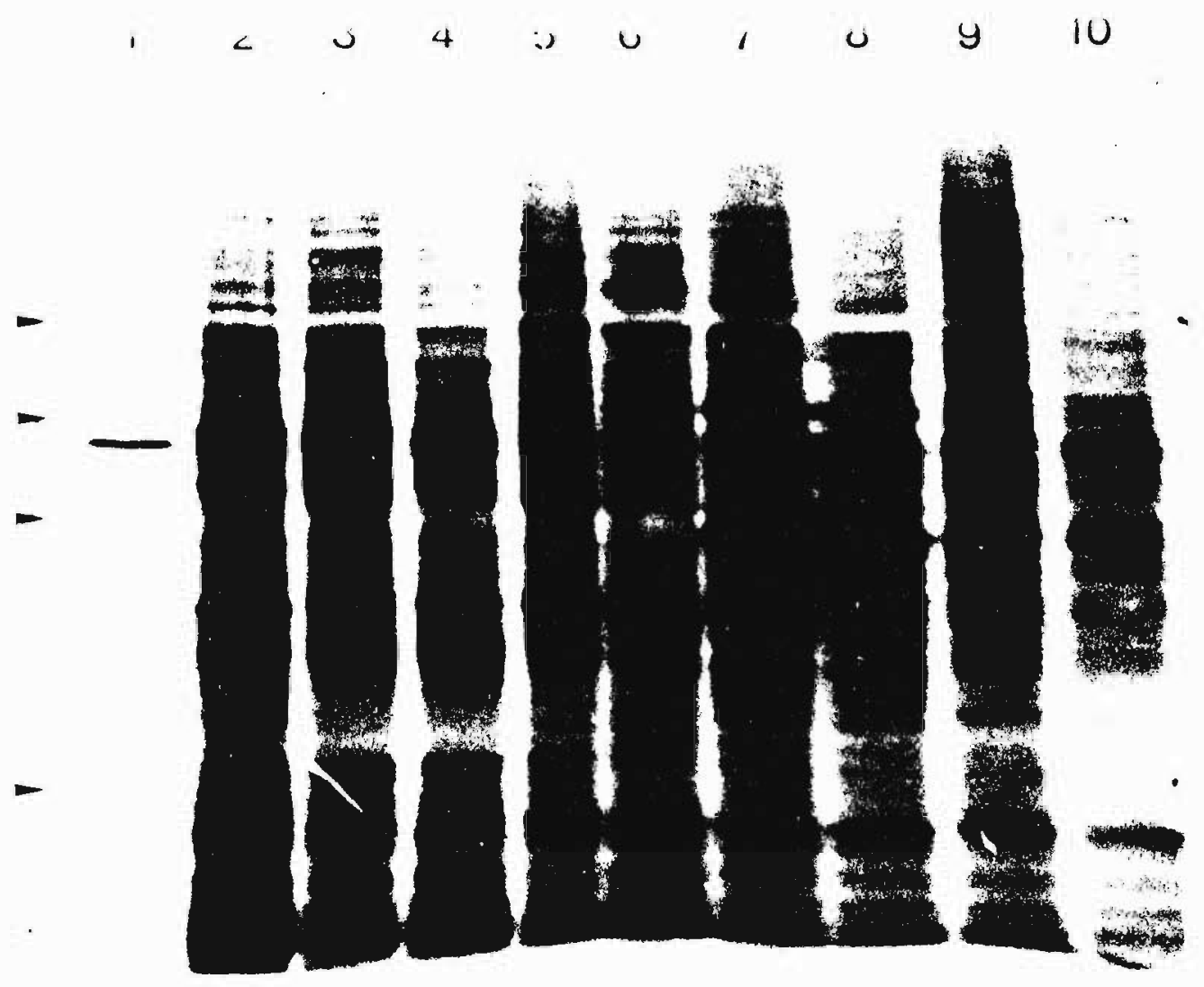

Figura 7 - Eletroforese unidimensional das produtos de traduçăo "in vitro" de RNAs poli(A)+ isolados de diferentes fases da esporulação: células vegetativas (2), células esporulantes de $60 \mathrm{~min}(3,4), 120 \mathrm{~min}(5,6), 180 \mathrm{~min}(7,8)$ e zoósporos $(9,10)$. Nos ensaios foram usadas duas concentraç8es de RNA poli( $(A)^{+}: 0,5 \mu g(2,3,5,7,9)$ e $1,0 \mu g$ $(4,6,8,10)$. No gel foram colocados $5 \mu l$ do ensaio. A canaleta 1 corresponde ao ensaio em que năo foi adicionado RNA (atividade endógena do lisado de reticulócitos). As setas à esquerda do auto-radiograma representam os marcadores de peso molecular $(67,55,45,25 \mathrm{kDa}$, de cima para baixa). 
85.

esporulaçăo e de zoósporos. Da análise do gel unidimensional podemos concluir que os ensaios onde foram utilizadas $0,5 \mathrm{\mu g}$ de RNA poli( + + foram mais eficientes. D restante das amostras correspondentes a esses ensaios mais eficientes foi entaro analisado através de eletroforese bidimensional.

Ds perfis eletroforéticos, obtidos nos sistemas IEF/SDS (Fig.8) e NEPHGE/SDS (Fig.9), das proteinas sintetizadas "in vitro" a partir dos RNA5 poli(A)+ de células vegetativas, células de 60, 120 e $180 \mathrm{~min}$ de esporulaçăo e de zoósporos, mostram a drástica variaçăo que ocorre na populaçă do RNA poli(A)+ traduzível, como era de se esperar dada a intensa variaçăo que havíamos detectado no padrăo de síntese proteica "in vivo".

A maioria dos RNAs poli $(A)$ + encontrados nas células vegetativas (Figs.8A e 9 ) desaparece após $60 \mathrm{~min}$ da induçăo da esporulaçăo, surgindo, entăo, novas populaçŏes de RNA poli $(A)+e m$ cada estágio da esporulaçao. D padrăo das proteínas sintetizadas "in vitro" a partir de RNAs poli(A)* isolados de zóosporos é bastante distinto dos demais padrốes obtidos. Aparentemente, poucos mensageiros sintetizados durante o crescimento e esporulaçăo até $180 \mathrm{~min}$ săo conservados nos zoósporos (Figs.8E e 9E). Resultados similares foram obtidos quando utilizamos RNA total para a traduçăo "in vitro" (năo mostrado). Além disso, o padrăo das proteinas sintetizadas "in vitro" a partir do RNA poli(A)+ (Fig.10A) e do RNA total (Fig.10日) de zoósporos é idéntico, 


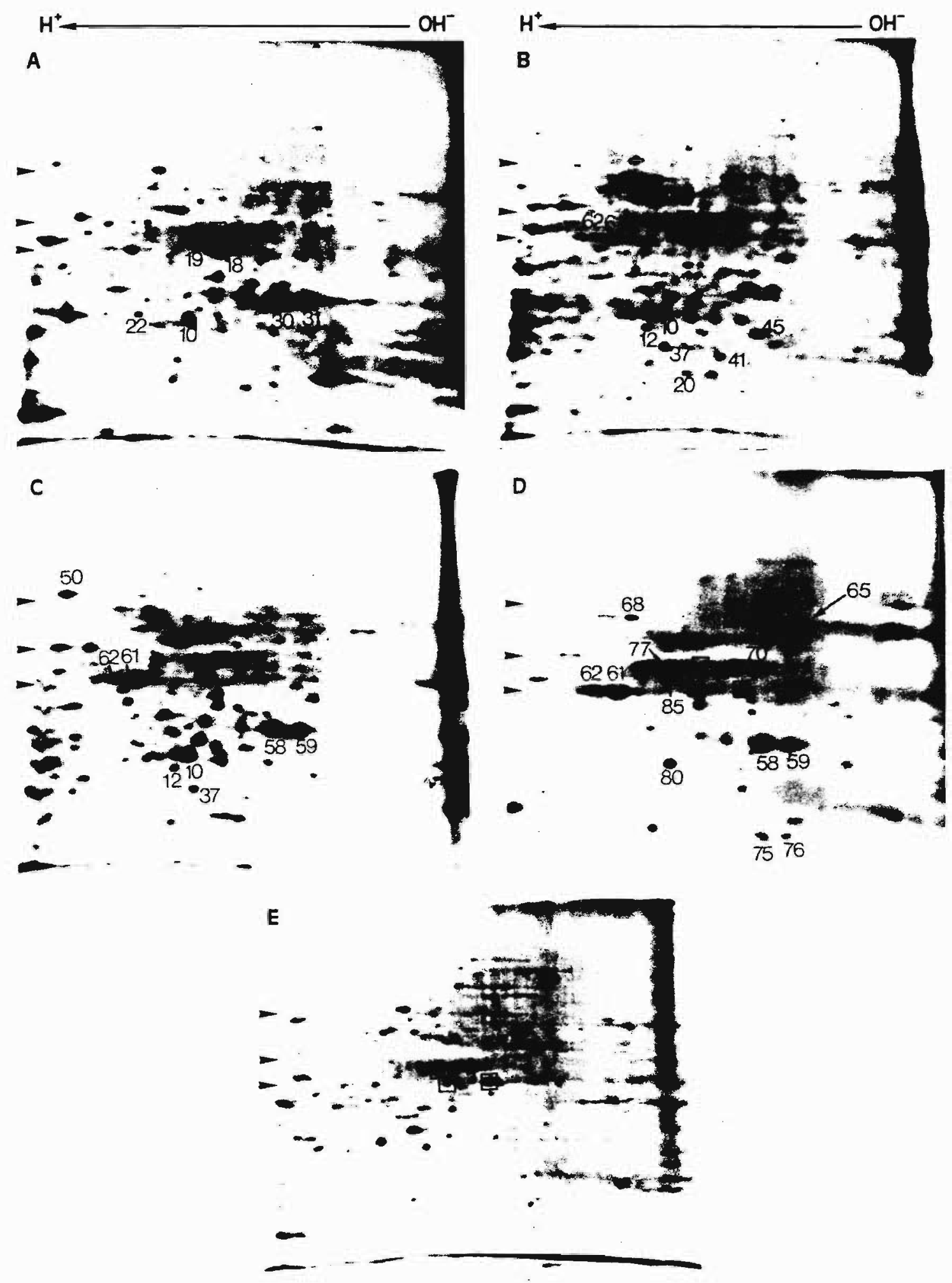

86.

Figura 8 - Eletroforese bidimensional (IEF/SDS) dos produtos de traduça "in vitro" de RNAs poli(A)+ isolados de diferentes fases da esporulaçăo: células vegetativas ( $(A)$, células esporulantes de $60 \mathrm{~min}$ (B), $120 \mathrm{~min}$ ( $[$ ), $180 \mathrm{~min}$ (D) e zoosporos (E). Os quadrados indicam polipeptidios cujo mRNA poli(A)* é conservado nos zósporos. As proteínas numeradas correspondem às proteínas sintetizadas "in vivo" identificadas na Fig.2. As setas à esquerda dos autoradiogramas representam os marcadores de peso molecular (67, $55,45 \mathrm{kDa}$, de cima para baixo). 
87.
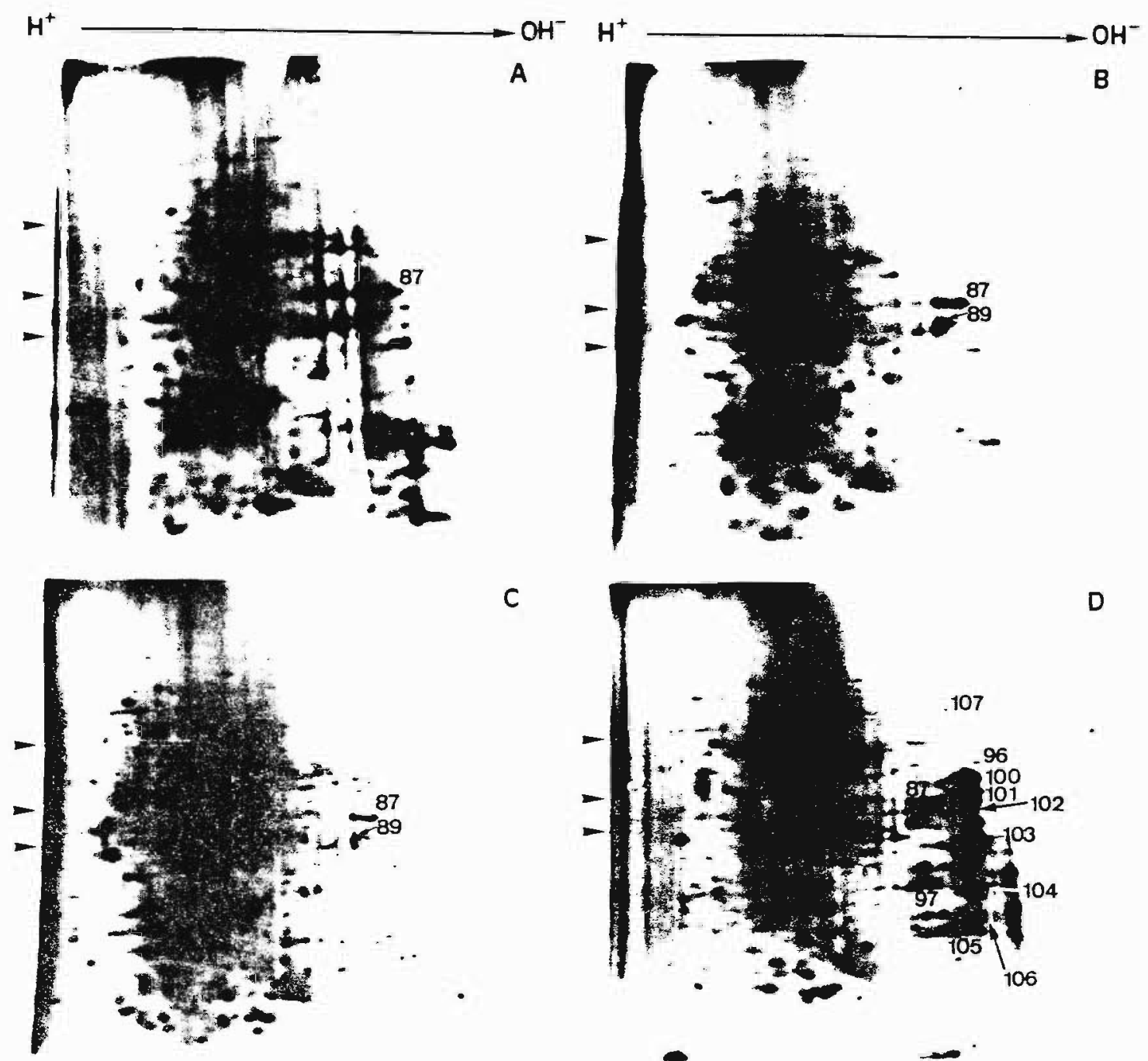

C
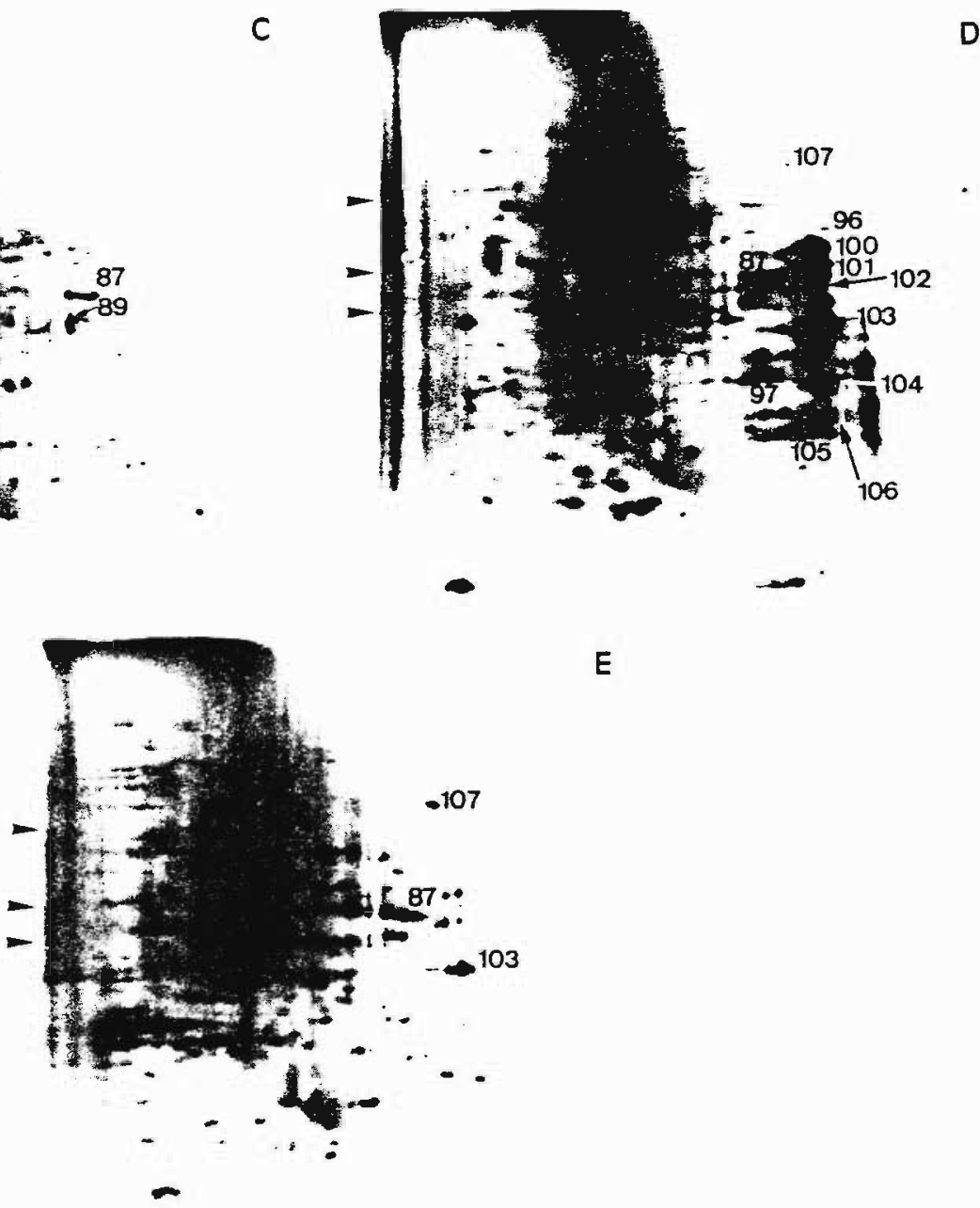

E

Figura 9 - Eletroforese bidimensional (NEPHGE/SDS) dos produtos da traduça "in vitro" de RNAs poli(A)+ de diferentes fases da esporulaça: células vegetativas ( $A$ ), células esporulantes de $60 \mathrm{~min}$ (B), $120 \mathrm{~min}$ (C), $180 \mathrm{~min}$ (D) e zoósporos (E). As proteinas numeradas correspondem às proteínas sintetizadas "in vivo" e identificadas na Fig. 3. As setas à esquerda dos auto-radiogramas representam os marcadores de peso molecular $(67,55,45 \mathrm{kDa}$, de cima para bai 0 o). 


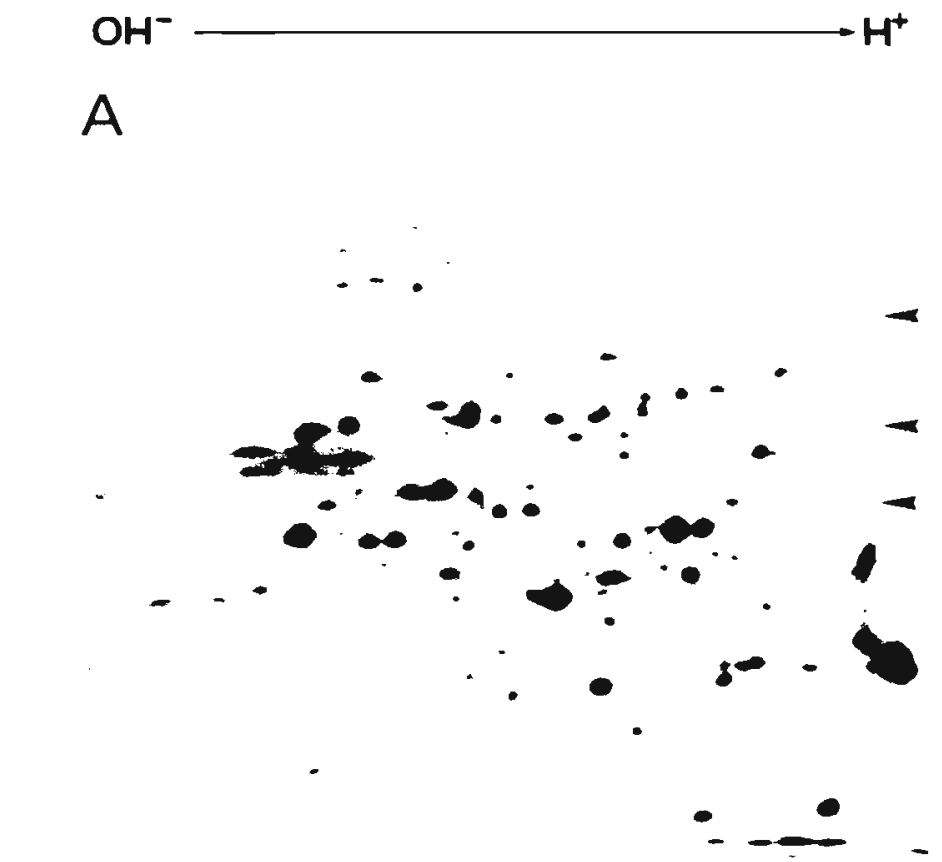

B

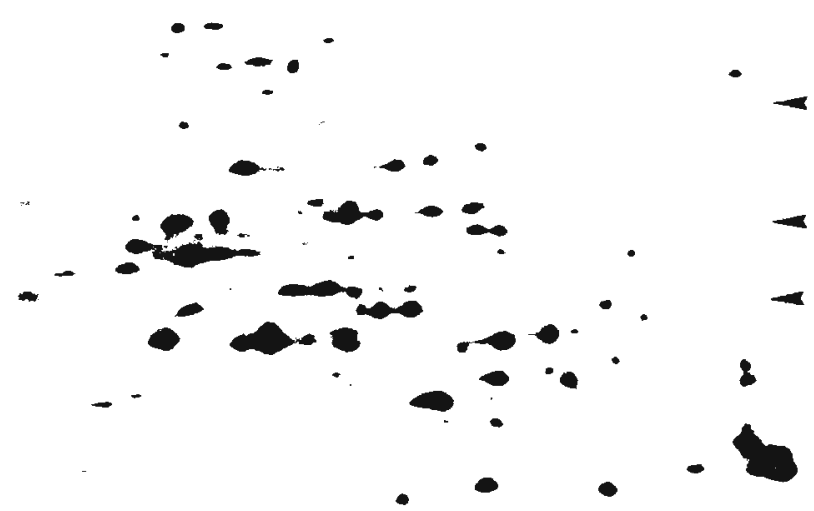

Figura 10 - Compara̧ăo das proteinas sintetizadas "in vitro" a partir de RNA poli(A)+ e RNA total isolado de zoósporos. RNA poli(A)+ (A) e RNA total (B) de zoosporos foram traduzidos "in vitro" e os polipeptidios resultantes foram analisados através de eletroforese bidimensional (IEF/SDS). As setas à direita (lado ácido dos auto-radiogramas) representam os marcadores de peso molecular (67, 55, 45 kDa, de cima para baixo). 
com apenas algumas variaçós na intensidade de algumas proteínas. Essa similaridade reflete a provável inexistência de diferenças entre a populaçăo de RNA poli(A)- e RNA poli(A)+ de zoósporos.

Através da comparaça do padra das proteínas sintetizadas "in vivo" com o padra dos produtos da traduça "in vitro" de RNAs poli(A)+ das diferentes fases da esporulaçăo, identificamos algumas das proteínas sintetizadas "in vivo" entre as proteinas sintetizadas "in vitro" (Figs.8 e 9). Entretanto, vários produtos da traduça "in vitro" năo correspondem às proteínas sintetizadas "in vivo" e várias proteínas resultantes da síntese "in vivo" naro foram encontradas entre os produtos de traduçăo "in vitro".

A maioria das proteínas básicas (96 a 108) sintetizadas "in vivo" no final da esporulaçăo (150-180 min) foram também sintetizadas "in vitro" a partir dos mRNAs poli(A)+ extraidos das células de $180 \mathrm{~min}$ (compare as figs.3H e 90 ). Dutras proteínas, cuja síntese é controlada pelo desenvolvimento, como por exemplo $37,45,50,58,59$ e 61 foram também identificadas na traduça "in vitro" ccompare as Figs.2 e 8). As variações na sintese destas proteinas observadas durante a esporulaçăo acompanham as variaçớes na concentraça dos seus respectivos RNAs mensageiros, sugerindo um controle ao nível da transcriça para os genes que codificam estas proteínas. 
90.

Um exemplo de controle ao nível da traducao foi verificado para a proteína 87. Esta proteina é sintetizada pelas células vegetativas e também no inficio da esporulaço, porém o mRNA para esta proteina existe durante toda a esporulaça persistindo inclusive nos zoósporos (Fig.9).

\subsubsection{Discuss 8.}

Como mostrado para os zósporos (Fig.1), foi necessária uma cuidadosa extraço das proteínas para evitarmos a intensa proteólise que normalmente se verifica nas células de B.emersonii Correa et al., 1978, 1979; Brochetto-Braga et al., 1982; Gomes et al., 1983). A degradaça de proteínas parece ser um evento essencial para a conversa das células vegetativas em zoosporângios (Correa et al., 1978). Durante a esporulaçăo, pelo menos $35 \%$ das proteínas das células vegetativas são completamente hidrolisadas pela maquinaria celular responsável pela proteólise (lodi e Sonneborn, 1974). Estes dados podem ser correlacionados com as dramaticas variaçós que observamos no padra das proteínas sintetizadas durante a esporulacgo.

Durante a esporulaça de B.emersonii encontramos mudanças muito rápidas no padrăo das proteínas sintetizadas nas diferentes fases, de acordo com a análise através da eletroforese bidimensional. Em adiça às proteinas feitas ao longo de toda a esporulaçă, as quais sao provavelmente indispensáveis para a manutenço de funçốs básicas da 
célula, observamos um grande número de proteínas cuja síntese é restrita a um determinado intervalo da esporulaçăo. Estas proteinas podem ser classificadas como proteinas cuja síntese é crítica para a transiçăo de um estágio da esporulaçăo ao estágio seguinte. Dutro grupo contém proteínas cuja sintese inicia-se entre 60 e $90 \mathrm{~min}$ e é mantida até o final da esporulaçăo. Coincidente com a fase de diferenciaça dos zósporos (150-210 min), ocorre a sintese de um outro grupo de proteinas, a maioria sendo proteínas basicas.

Estudos anteriores demonstraram que alguns dos RNA poli( $($ ) presentes nas células em crescimento eram conservados nos zoósporos e que, em contraste, a maioria do RNA poli $(A)$ + sintetizado durante toda a esporulaça era degradado e apenas aqueles produzidos no últimos minutos da esporulaça eram preferencialmente armazenados nos zoósporos; cerca de um terço do mRNA mantido nos zoósporos correspondia ao RNA transcrito durante os 30 minutos finais da esporulaçăo (Jaworski e Thomson, 1980). Contudo, nada era conhecido sobre as proteinas que eram codificadas por esses mRNAs .

Nossos resultados indicam que a intensa variaço do padra das proteínas sintetizadas "in vivo" durante a esporulaçăo reflete a extrema variabilidade da populaçao de mRNAs, como demonstrado através da análise dos produtos da traduçăo "in vitro" dos RNAs poli(A)+ isolados em diferentes estágios da esporulaçăo. A esporulaçăo é caracterizada pelo 
desaparecimento de certas mensagens presentes durante o crescimento e pelo aumento na quantidade de mRNAs estágioespecificos. Estes mRNAs estágio-específicos săo rapidamente renovados, provocando as numerosas variaçós que verificamos nos padräes bidimensionais dos produtos da traduça "in vitro" dirigida pelos RNAs poli(A)+ isolados de células de 60,120 e $180 \mathrm{~min}$ da esporulaçăo. A maioria das mensagens estágio-específicas desaparecem, năo sendo encontrada entre a populaçăo de mensagens que é armazenada nos zoósporos, sendo que poucas mensagens sintetizadas na esporulaçăo e crescimento foram conservadas nos zoósporos. Estes dados levam à conclusaro que uma quantidade substancial do mRNA poli(A)+ presente nos zoósporos foi sintetizada nos últimos 30 minutos da esporulaçao. Os zoósporos também contém RNA năo-poliadenilado (Jaworski et al., 1976; Johnson e Lovett, 1984a). Contuda excluimos uma possível diferença entre esta populaçăo năo-poliadenilada e a populaçăo poliadenilada, uma vez que o padra bidimensional dos produtos da traduçăo "in vitro" do RNA total é semelhante ao obtido pela traduça "in vitro" do RNA poli(P)+. Provavelmente muitas mensagens sa encontradas em ambas as populaçós de RNAs de zoósporos.

A sintese "in vivo" de algumas proteínas, síntese essa regulada pelo desenvolvimento, coincide com o momento em que os RNAs poli(A)+ especificos para estas proteínas podem ser identificados através da traduça "in vitro". Este fato sugere que os genes que codificam para essas proteínas estao 
sob um controle ao nivel da transcriça. Contudo, poderia estar ocorrendo um controle a nivel de adenilaçăo/desadenilaçăo e que năo estaria sendo detectado pelo nosso ensaio de traducgo "in vitro". Palatnik et al. (1984) sugeriram que o grau de adenilaça de RNAs pode depender do estado de desenvolvimento da célula. Nossas resultados, contudo, descartam esta possibilidade, uma vez que a traduçăo "in vitro" do RNA total isolado nas diferentes fases da esporulaçăo e de zoósporos confirmam que a maioria das variaçoes no padrăo das proteínas sintetizadas "in vivo" estao sob un controle ao nível da transcriça.

No entanto, é necessário considerar que apesar das intensa variaçăo na populaçăo de RNA poli(A)+, várias proteinas sintetizadas "in vivo" nao foram identificadas entre os produtos de traduçăo "in vitro". Este fato provavelmente é devido a incapacidade do sistema de traduço "in vitro" de realizar processamento ou modificaçôs póstraduça nas proteinas sintetizadas, como provavelmente ocorre após a síntese "in vivo".

Através de estudos de hibridizaçăo RNA/DNA em soluçăo, Johnson e Lovett (1984b) mostraram que $80 \%$ da complexidade do genoma era expresso ao longo da esporulaça, mas apenas 40x era conservado nos zoósporos. Nós ngo podemos comparar diretamente nossos estudos com os estudos de hibridizaçăo de Johnson e Lovett, uma vez que eles nåo estudaram as variações nas diferentes classes do mRNA (abundante, intermediária e escassa) durante a esporulaçăo. 
procedimento que utilizamos detecta apenas proteinas codificadas por mRNAs das classes abundante e intermediária. Apesar das limitaçöes do sistema de traduço "in vitro", nossos estudas mostraram a ocorréncia de variações na população de mRNA ao longo da esporulaça. o fato de que a maioria das mensagens especificas da esporulaça năostá presente nos zoosporos maduros correlaciona-se bem com o resultado de Johnson e Lovett (1984b), que indica que metade da complexidade expressa durante a esporulaça năo se encontra entre o grupo de mRNAs armazenados nos zoósporos. 


\subsection{Sintese de proteinas durante a germinaçăo}

Durante a germinaçăom meio inorgânico e em meio nutriente contendo ou năo actinomicina $D(5 \mu g / m L)$ foram administrados pulsos de jas/metionina, consecutivos e com duraça de 10 minutos. As proteínas totais marcadas radioativamente foram analisadas através de eletroforese bidimensional (IEF/SDS e NEPHGE/SDS). Precauçöes com a proteólise também foram tomadas como comentado no item III.1.1. A figura 11 compara dois métodos de lise de germes que tiveram suas proteínas marcadas "in vivo" com lass/metionina ao longo de toda a germinaço, confirmando, assim, a eficiência do tratamento com TCA 10\% para se evitar a proteólise.

A radioatividade incorporada em proteínas durante a germinaçăo em soluçăo inorgânica ou meio nutriente na ausência e presença de actinomicina $D$ foi medida pelo método de precipitagyo com TCA a quente. o resultado dessa quantificaçăo está apresentado na Fig.12. Em soluçăo inorgânica o rápido aumento da incorporaçăo foi seguido por um plató (Fig.12A), enquanto que em meio nutriente a incorporaçăo aumenta exponencialmente, embora a porcentagem total de radioatividade incorporada tenha sido bem menor devido à presença de metionina nao-radioativa neste meio (Fig.12B). Na presença de $5 \mu g / m l$ de actinomicina $D$, concentraçăo esta capaz de inibir 95\% da incorporaçăo de uridina (Leaver e Lovett, 1974; nossos resultados não 

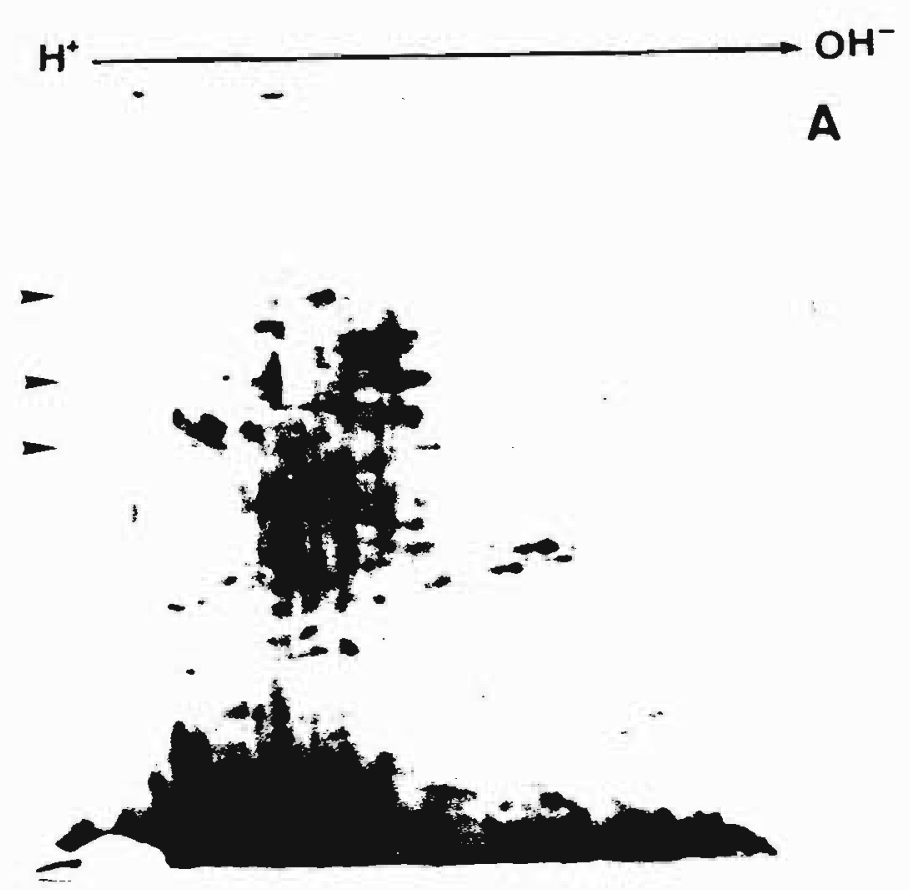

B

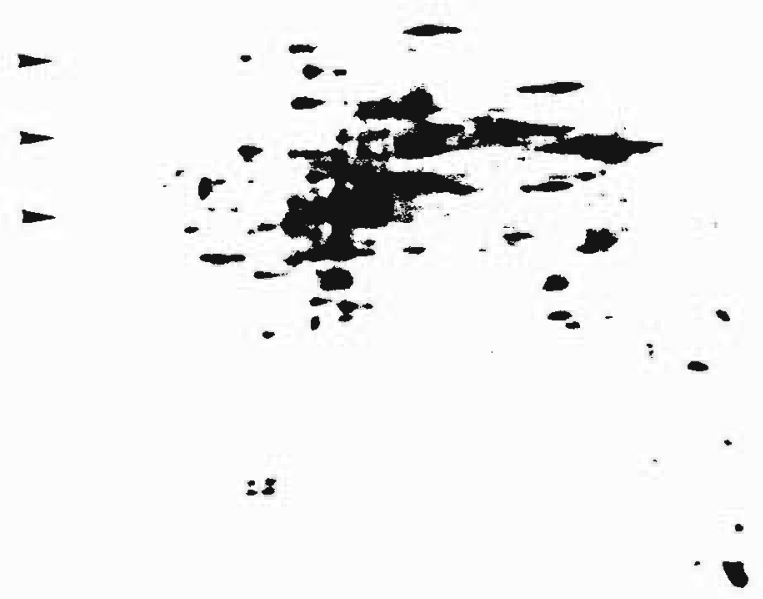

Figura 11 - Eletroforese bidimensional (NEPHGE/5DS) de proteínas isoladas de germes. As células foram marcadas com |3s 5 |metionina ao longo da germinaço e os germes foram congelados e descongelados na presença de tampao de eletroforese bidimensional ( $A$ ) ou imediatamente precipitados com TCA como descrito em Procedimentos Experimentais ( $B$ ). Hs setas à esquerda (lado ácido dos auto-radiogramas) representam os marcadores de peso molecular (67, 55, 45 kDa, de cima para baixol. 
mostrados), a cinética e a sincronia da germinaça foram similares ao controle, pelo menos até os $50 \mathrm{~min}$. Apos este momento parece ocorrer uma inibiço da elongaça do tubo germinativo. 0 aumento inicial na incorporaço de metionina năo foi afetado por este inibidor; contudo, após 25 min foi observado um decréscimo significativo na incorporaço de jas Smetionina nas células tratadas com actinomicina D.

\subsubsection{Padrao das proteínas sintetizadas durante a germinação em soluçăo inorgânica}

A eletroforese bidimensional no sistema IEF/SDS permitiu a deteç̧a de aproximadamente 400 polipeptidios sintetizados durante a germinaçăo em meio inorganico, sendo que a sintese de 150 foi analisada. As proteínas mais básicas foram analisadas no sistema NEPHGE/SDS e um total de 20 polipeptídios básicos foram identificados na regiaro mais básica do gel. A figura 13 mostra os perfis eletroforeticos das proteínas sintetizadas durante o inicio da germinaçăo em soluçăo inorgânica, na ausência e na presença de actinomicina $D$. Durante o primeiro pulso ( 5 a $15 \mathrm{~min}$ ), năo foi detectada incorporagao de lass/metionina (Fig.129); contudo, uma exposiça prolongada do gel ao filme de Raios-X permitiu a detecça de sintese proteica neste pulso inicial (Fig.13R). D padrăo das proteínas sintetizadas nos intervalos 5 a 15 e 15 a $25 \mathrm{~min}$, na presença ou ausência de actinomicina $D$, é praticamente idêntico (Fig.13), indicando 
98.
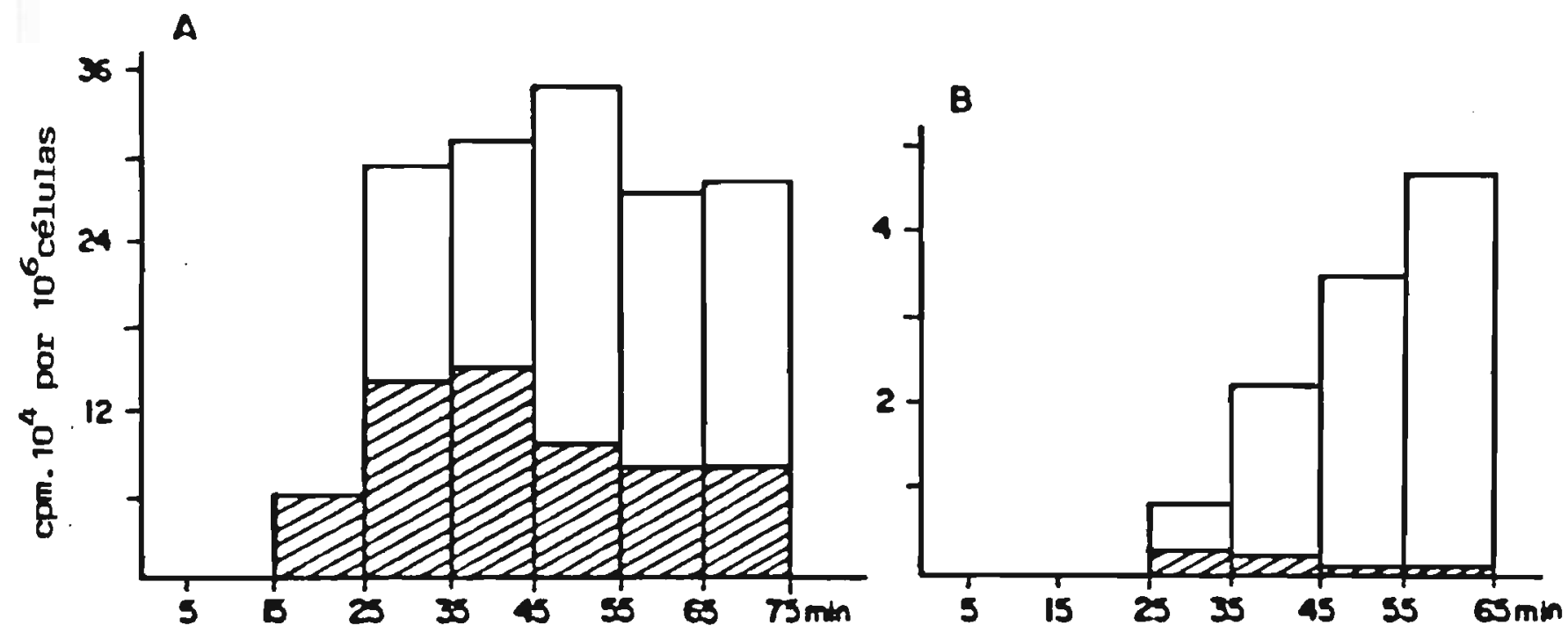

Figura 12 - Efeito de actinomicina $D$ na incorporacgo de 1355/metionina em proteinas totais durante a germinaca. Células foram marcadas com lass/metionina por intervalos de 10 min durante a germinaçao em meio inorganico (A) ou meio nutriente ( $B$ ) na presença (barra hachurada) ou ausência (barra vazia) de actinomicina $D(5 \mu g / m l)$. Em todos os casos a germinaça foi sincrônica; após $20 \mathrm{~min}$ virtualmente $100 \%$ das celulas correspondiam ao fenótipo célula redonda e, apos $45 \mathrm{~min}, 100 \%$ das células correspondiam a germes. 

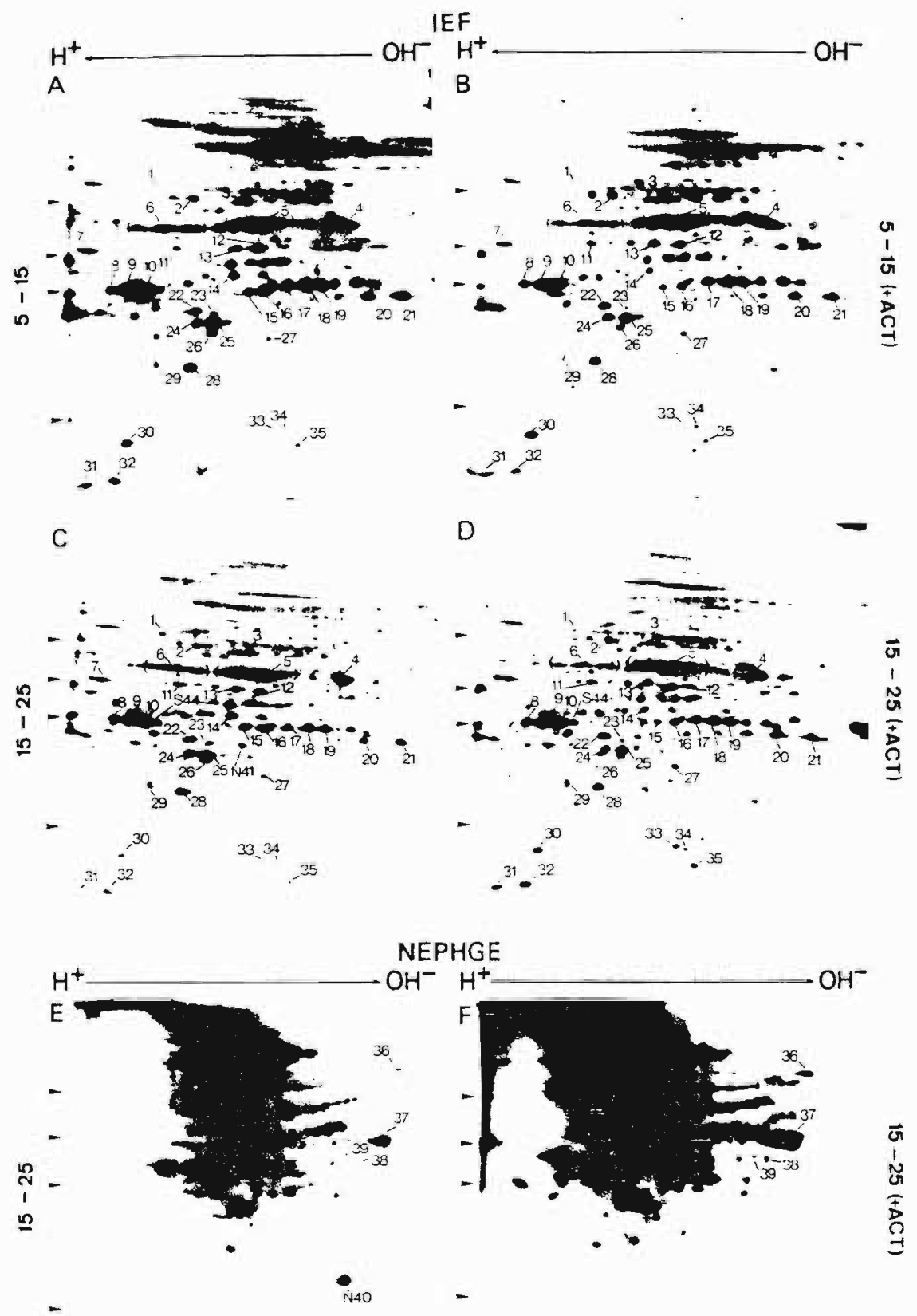

Figura 13 - Padra das proteinas sintetizadas durante o início da germinaçao. Zoósporos foram induzidos a germinar em soluçăo inorgânica na presença $(B, D, F)$ ou ausência $(A, C, E)$ de actinomicina $D$, que foi adicionada no tempo zero. As células foram marcadas com lass/metionina por $10 \mathrm{~min}$ nos intervalos indicados e as proteínas totais foram extraidas e analisadas através de eletroforese bidimensional. As setas a esquerda (lado ácido dos auto-radiogramas) representam os marcadores de peso molecular $(67,55,45$ e $25 \mathrm{kDa}$, de cima para baixo). 
que os zoósporos contém mRNA armazenado, que é traduzido já nos primeiros minutos de induçăo da germinaçăo. Ds polipeptidios mais proeminentes foram numerados ( 1 a 39 ). Apenas um único polipeptidio (N41), identificado no sistema IEF/SDS (Fig.13[), e um polipeptidio básico (N40), identificado no sistema NEPHGE/SDS (Fig.13E), nå foram sintetizados na presença de actinomicina $D$.

Após 25 minutos do início da germinaça observamos uma variação significativa na velocidade de síntese de várias proteínas. Pelo menos 28 novos polipeptidios aparecem entre 25 e $55 \mathrm{min,}$ a maioria sendo inibida na presença de actinomicina $\quad$ (Figs.14 e 15). Estas proteinas, cujo aparecimento envolve sintese de novos mRNAs, foram designadas com a letra $\underline{N}$ (do inglês "new" mRNA). Contudo, detectamos algumas novas proteínas, cuja sintese é independente da transcriçáo de novos mRNAs, proteínas estas designadas com a letra $\underline{5}$ (do ingles "stored" mRNA). Na figura 14 podemos visualizar cinco novos polipeptidios ( 544 , $545,547,550,551)$, que săo sintetizados entre 25 e 35 min e um (558), que é sintetizado entre 35 e $45 \mathrm{~min}$, tanto na ausência como na presença de actinomicina D. Este fato sugere que no processo de germinaça existe um mecanismo de traduçăo envolvendo seleçăo dos mRNAs previamente armazenados nos zósporos.

Paralelamente ao aumento da sintese de várias proteínas, que ocorre após 25 min da germinaça, observamos uma diminuiça na sintese de outras proteínas cpolipeptidios 
101.
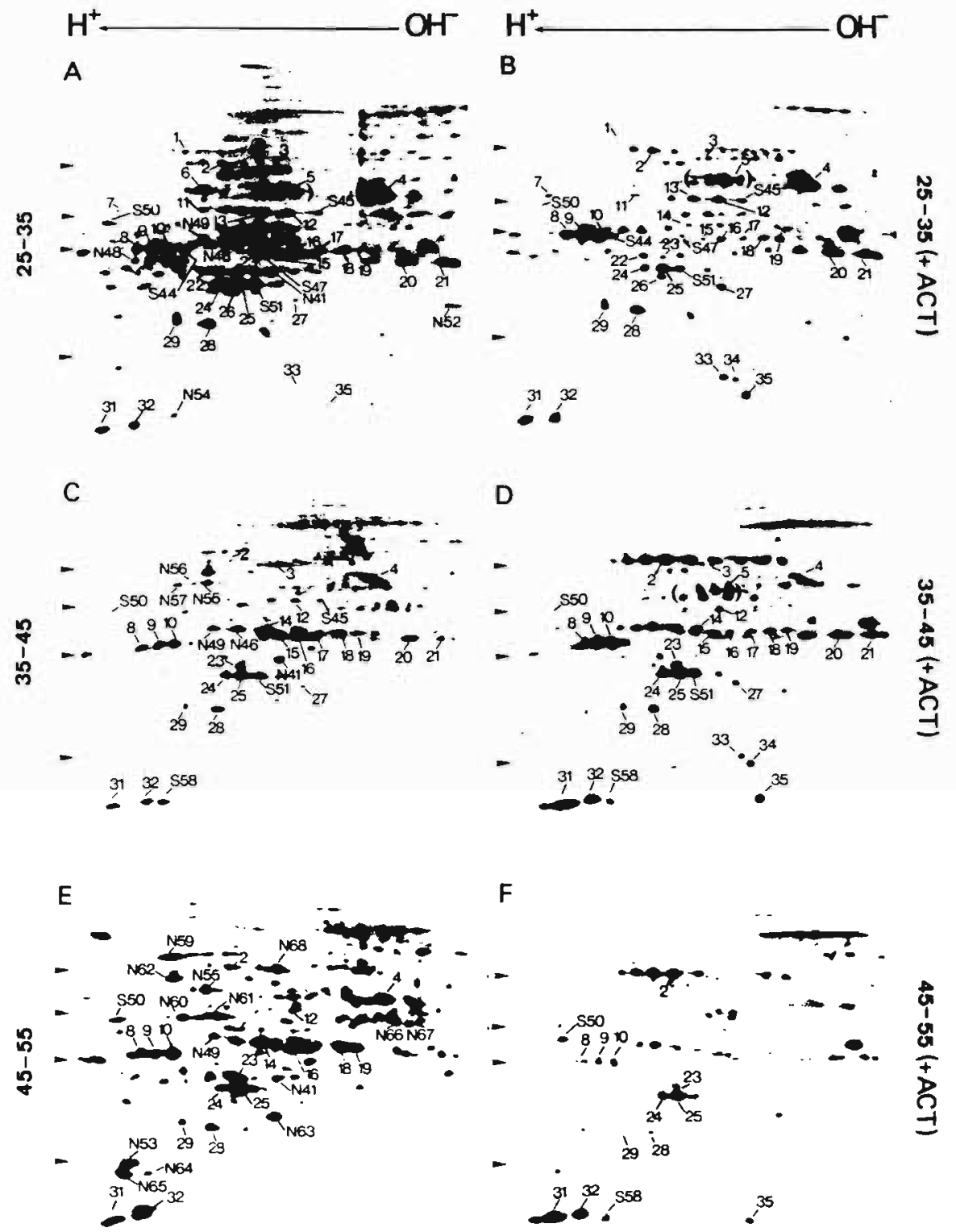

Figura 14 - Eletroforese bidimensional IEF/SDS de proteinas sintetizadas durante a germinaço tardia em soluço inorganica. Como descrito na legenda da figura 13. ACT, actinomicina 0 . 
102
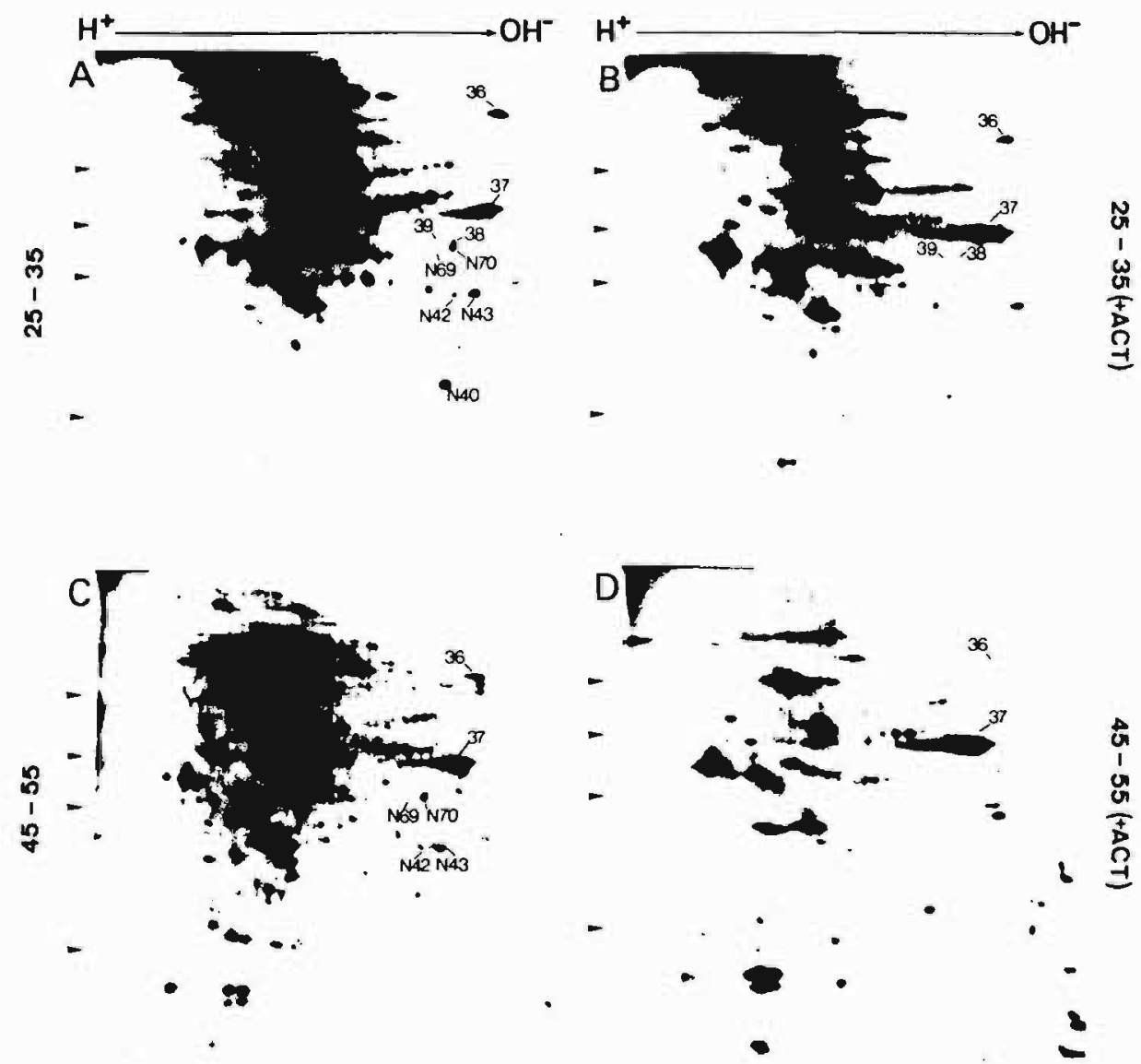

Figura 15 - Eletroforese bidimensional NEPHGE/SDS de proteínas sintetizadas durante a germinaça tardia em soluçăo inorgânica. Como descrito na legenda da figura 13. $A C T$, actinamicina D. 
3 а $7,11,20$ a $22,27,30,33$ a $35,38,39$ ) (Fig.14 e 15). Em alguns casos esta diminuiçăo é atrasada na presença de actinomicina D cor exemplo, polipeptidios $5,20,21,33$ a 35). Além disso, após 35 min ocorre um intenso aumento na sintese de algumas proteínas na germinaço induzida na presença de actinomicina D em relação ao controle (Figs.14D, FJ, indicando que a meia-vida de certos mRNAs foi afetada pela inibiçăo da transcriçăo.

\subsubsection{Padrăo das proteinas sintetizadas durante a} germinaçชo em meio nutriente $A L$

Com a finalidade de se detectar alguma eventual diferença entre o padrăo das proteínas sintetizadas durante a germinaçăo em meio inorgânico e o padrăo das protelnas sintetizadas durante germinaça induzida em condiçớs de crescimento, analisamos a sintese proteica durante germinação em meio $A L$. D meio de crescimento AL contém baixa concentração de metionina $(5 \mu M)$, o que permite boa incorporaça de jas/metionina, sem contudo afetar a cinética de germinação e o crescimento normal das células.

Para o estudo da sintese proteica durante a germinaçăo em meio AL foram administrados quatro pulsos consecutivos de |3ss/metionina ( 10 min de duraçăo), a partir dos $25 \mathrm{~min}$ da indução da germinaçăo na presença e na ausência de actinomicina D. Nas Figs. 16 e 17 (respectivamente sistemas IEF/SDS a NEPHGE/SDS) såo mostrados os auto-radiogramas 

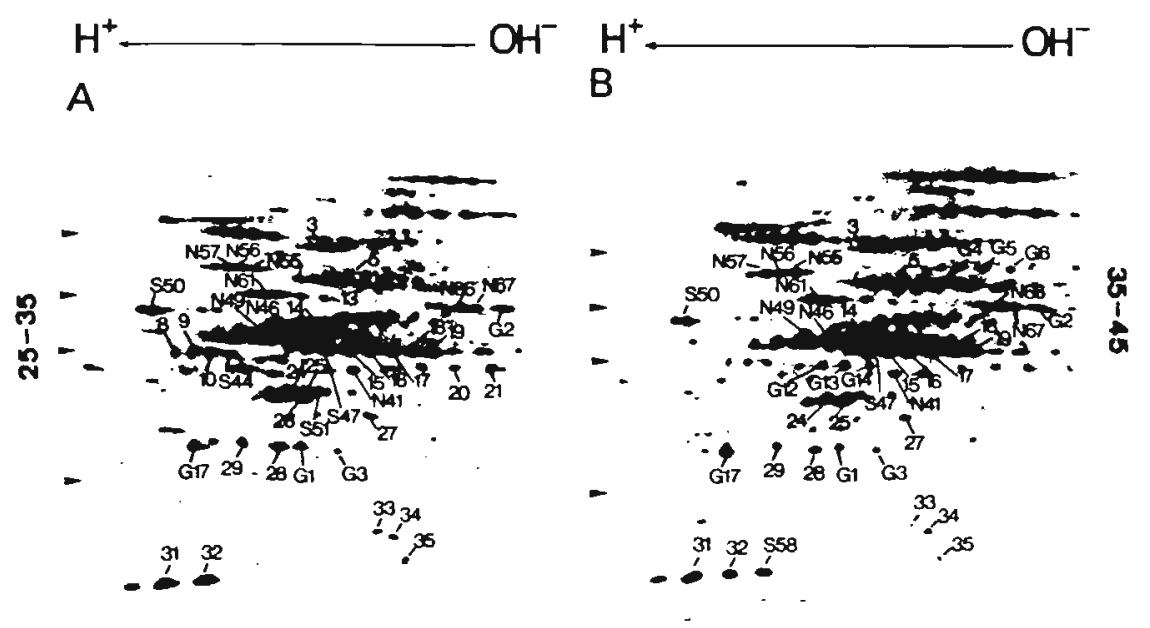

C

D

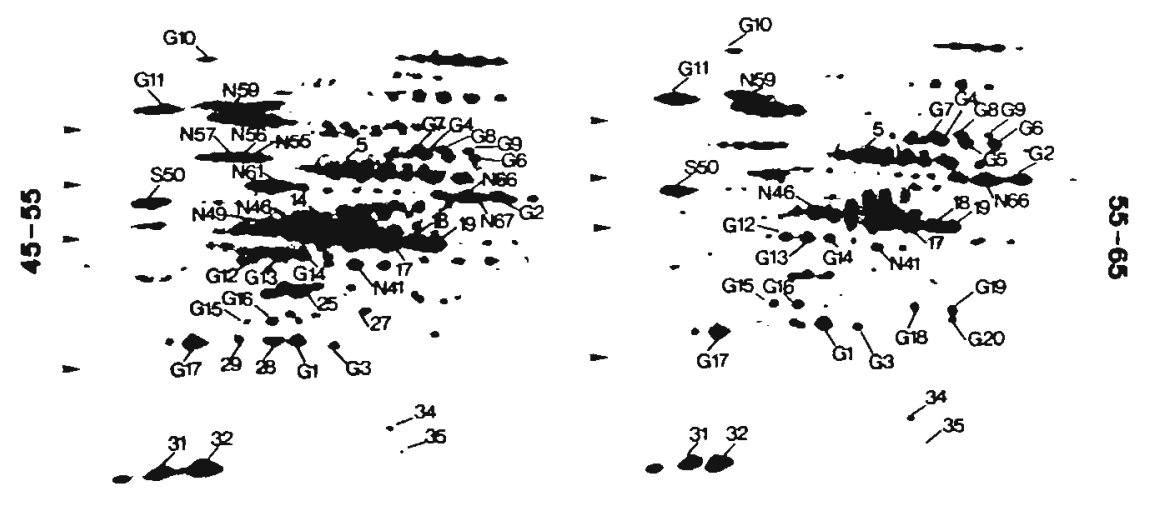

Figura 16 - Padrão das proteinas sintetizadas durante a germinação em meio nutriente. Zoósporos foram induzidos a germinar em meio AL. As células foram marcadas com |35s/metionina por $10 \mathrm{~min}$ nos intervalos indicados e as proteinas totais foram extraidas e analisadas através de eletroforese bidimensional IEF/SDS. As setas à esquerda ( $l$ ado ácido dos auto-radiogramas) representam os marcadores de peso molecular (67, 55, 45 e $25 \mathrm{kDa}$, de cima para baixo). 
105.

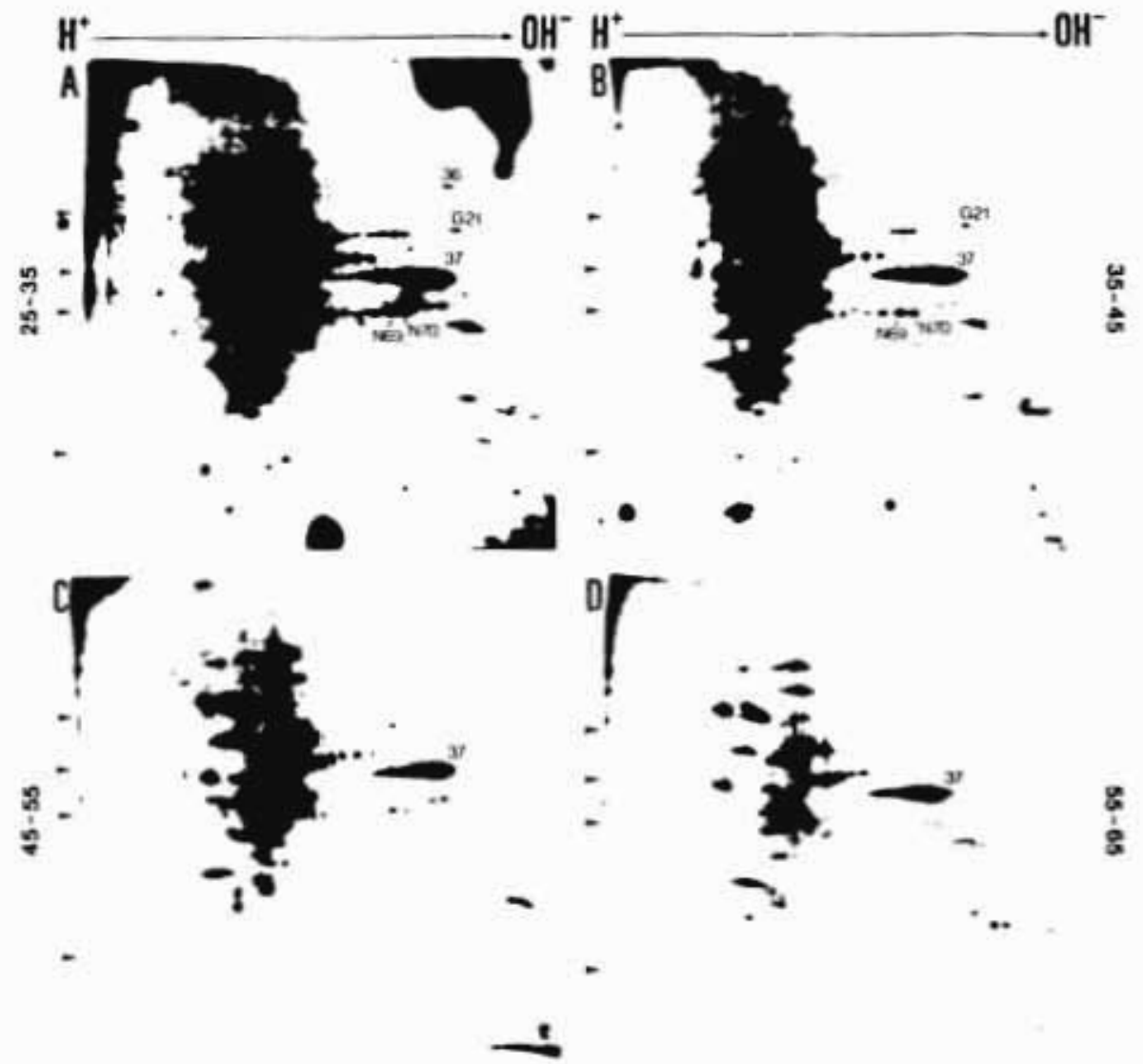

Figura 17 - Eletroforese bidimensional NEPHGE/SDS das proteinas sintetizadas durante a germinaço em meio nutriente. Como descrito na legenda da figura 16. 
106.

correspondentes ao padrao das proteinas sintetizadas na ausência de actinomicina D. Năo estao apresentados os autoradiogramas correspondentes à síntese proteica na presença de actinomicina $D$, uma vez que a incorporaço foi extremamente baixa. Embora o gradiente de $\mathrm{pH}$ dos géis de 1 . dimensăo no sistema IEF/SDS (Fig.16) seja ligeiramente diferente do gradiente de pH dos géis IEF anteriormente apresentados, devido a uma mudança no lote de anfolitos, isto nå dificultou a identificaça das proteínas.

A comparaçăo entre o padrão das proteínas sintetizadas em meio inorgânico (Figs.13, 14 e 15) com o padrăo das proteinas sintetizadas em meio nutriente (Figs.16 e 17) revela que a maioria dos polipeptidios previamente identificados no inicio da germinaça, em soluçăo inorgânica, foram também detectados entre as proteinas sintetizadas na germinação em meio nutriente. Além disso, a maioria dos polipeptidios identificados como $N$ e alguns classificados como $\underline{5}$ (Fig.14 e 15) foram também identificados (Figs.16 e 17). Várias dessas proteínas tem o momento de sua sintese antecipado (frequentemente um pulso antes), indicando que durante a germinaça em meio $\mathrm{gL}$ a sintese proteica parece estar mais adiantada que na germinação em meio inorgânico.

Verificamos, também, a sintese de um número significativo de novos polipeptidios (cerca de 20 ), exclusivamente na germinaçăo em meio AL (Fig.16 e 17). Estes polipeptidios foram designados pela letra $\underline{G}$ (do ingles 
107.

"growth"). Vários desses polipeptidios, especificos de crescimento, foram de fato encontrados ao analisarmos a síntese de células vegetativas em crescimento Cresultado năo mostrados.

\subsubsection{Traduçăo "in vitro" de RNAs isolados durante a} germinaçå

Com o objetiva de se confirmar as dados obtidos a partir dos experimentos de sintese "in vivo" na presença de actinomicina D, RNA total isolado de zoósporos, de células após 20 e 45 min de germinaçăo em meio inorgânico e de células após $45 \mathrm{~min}$ de germinaçăo em meio $\mathrm{AL}$, foi traduzido em Lisado de reticulácitos de coelho. Ds produtos da traduçăo "in vitro" desses RNAs foram separados em eletroforese bidimensional no sistema IEF/SDS.

o padrao dos produtos da traduçă "in vitro" do RNA isolado de zoósporos é muito semelhante ao obtido da tradução do RNA de células após $20 \mathrm{~min}$ da indução da germinaçăo (Figs. 18R, B), indicando que năo ocorre síntese de novos RNAs no início da germinaçăo. Contudo, uma boa parte dos RNAs que estavam armazenados nos zoósporos săo degradados até 45 min da germinaçăo, enquanto uma menor parte é conservada pelo menos até os 45 min de germinaçăo (Figs.18A, [). Entre as proteinas sintetizadas a partir da tradução do RNA de células de $45 \mathrm{~min}$ (Fig.18[, D) podemos detectar algumas novas proteinas correspondentes aos novos 
108.
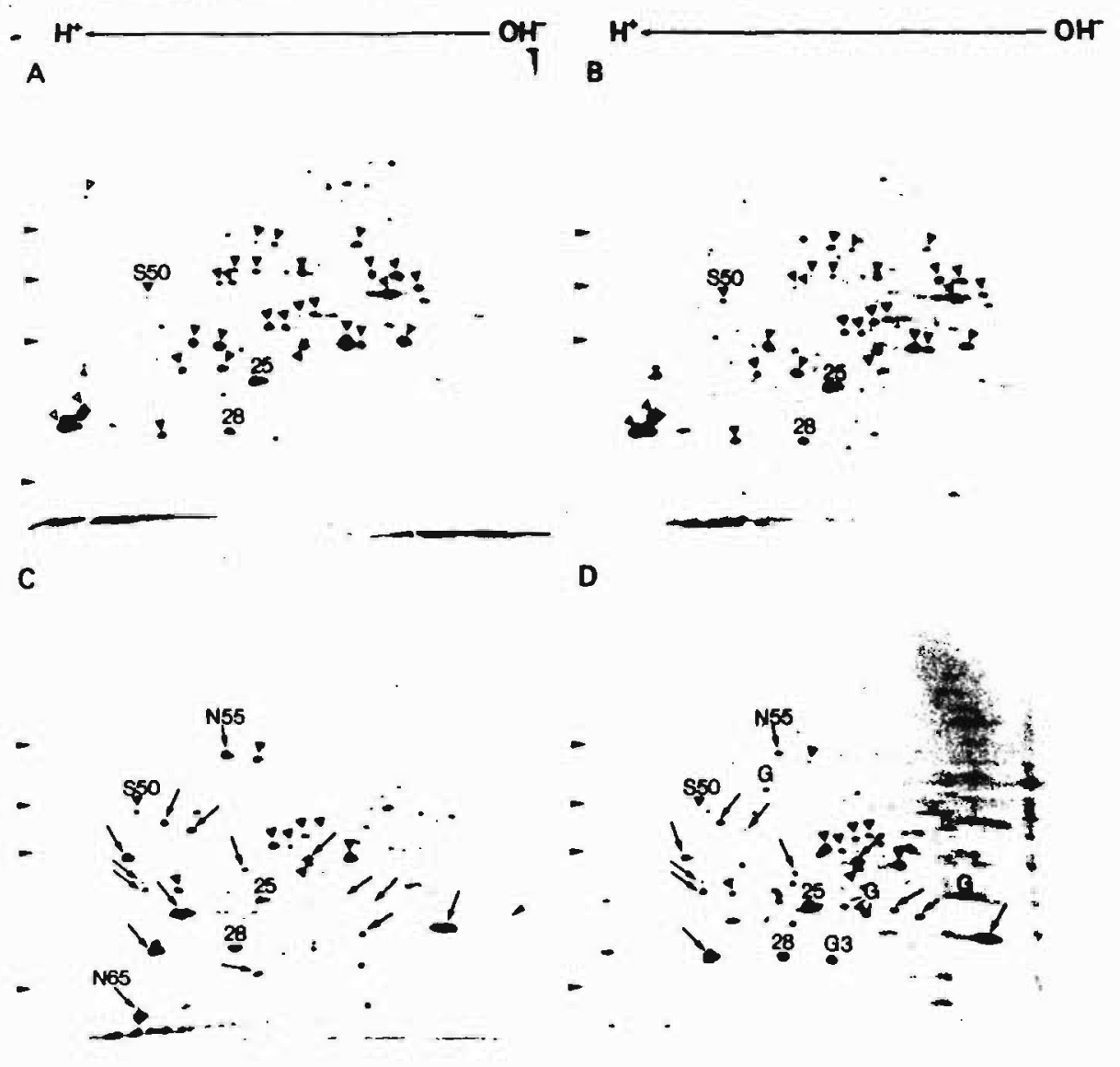

Figura 18 - Eletroforese bidimensional (IEF/SDS) dos produtos de traduçăo "in vitro" de RNA total isolado de zoósporos (A), células após $20 \mathrm{~min}$ ( $B$ ) e $45 \mathrm{~min}$ ( $C$ ) de germinaçăo em soluçăo inorgânica e após 45 min de germinaça em meio nutriente $A L$ (D). Triângulos fechados indicam polipeptidios codificados por RNAs armazenados nos zoosporos que săo mantidos até $45 \mathrm{~min}$ de germinaça e triângulos abertos aqueles que desaparecem. As setas apontam polipeptidios codificados por RNAs sintetizados de novo. Os polipeptidios exclusivos de meio nutriente sa identificados pela letra $G$. As proteínas numeradas correspondem àquelas proteínas sintetizadas "in vivo" e identificadas nas Figs.14 e 16. As pontas de setas a esquerda dos auto-radiogramas representam os marcadores de peso molecular $(67,55,45$ e 25 $k D a$, de cima para baixo). 
RNAs que săo transcritos após os 20-25 min da germinaçăo. Além disso, várias outras proteínas correspondentes a novos mRNAs foram detectadas na traduça "in vitro", embora năo tenhamos encontrado estas proteínas no padra das proteínas sintetizadas "in vivo".

Ho compararmos o padrăo obtido da traduça "in vitro" do RNA isolado das células de $45 \mathrm{~min}$ de germinação em meio inorgânico com o de células obtidas em meio nutriente hL, (Fig. 18[, D) podemos visualizar algumas diferenças, como o aparecimento de alguns novos produtos de tradução exclusivos da germinaçăo em meio $\mathrm{AL}$, o que confirma a idéia de que já durante a germinaçăo em meio nutriente tem início a expressaro de novos genes provavelmente relacionados como crescimento dessas células.

\subsubsection{Modificaçôes pós-traduçao das proteínas de zoósporos durante o inf́cio da germinaçăo}

Possíveis modificações pós-traduçăo devem ocorrer no inicio da germinaçăo, uma vez que as transformaçoes que ocorrem nesta fase devem depender essencialmente de modificaçăes nas proteínas preexistentes nos zoósporos. A transformaçăo morfológica zoósporo --) célula redonda é independente de sintese proteica, ocorrendo na presença de cicloeximida (Lovett, 1968; Soll e Sonneborn, 1971b).

Para verificar a existência de tais modificaçoses, zoósporos marcados radioativamente com |35s/metionina 
durante toda a esporulaçăo foram coletados e induzidos a germinar em soluçăo inorgânica contendo excesso de metionina não-radioativa $(0,2 \mathrm{mM})$. Foram coletadas células após 6,12, 18 e $25 \mathrm{~min} e$ as proteínas foram analisadas através de eletroforese bidimensional (IEF/SDS e NEPHGE/SDS). As figuras 19 e 20 mostram os perfis eletroforéticos obtidos nestes diferentes momentos.

o padråo das proteínas dos zoósporos (Figs.19A,20A), que representa as proteínas sintetizadas durante toda a esporulação e conservadas nos zoósporos, difere significativamente do padra das proteinas sintetizadas durante a germinaçăo (Figs.13 a 15). Durante o início da germinação as proteínas dos zoósporos sao relativamente estáveis. Contudo, algumas proteínas sa processadas ou degradadas logo no inicio da germinaçăo, enquanto que outras mais tardiamente. Entre estas últimas está um grupo de proteinas básicas de peso molecular entre 55 e 40 kDa, detectadas no sistema NEPHGE/SDS (Fig.20), cujo desaparecimento ocorre entre 18 e 25 min; estas proteínas haviam sido sintetizadas exclusivamente durante a diferenciação dos zósporos que ocorre no final da esporulação (Fig. 3H).

Existem algumas proteinas que aparentemente sofrem modificaçốs no seu ponto isoelétrico. Alguns polipeptídios tornam-se mais básicos $(b, c, d)$ ( $F i g .19)$, enquanto outros tornam-se mais ácidos (a,e) (Fig.19), sugerindo que modificaçชes do tipo fosforilaçăo-desfosforilaça, 

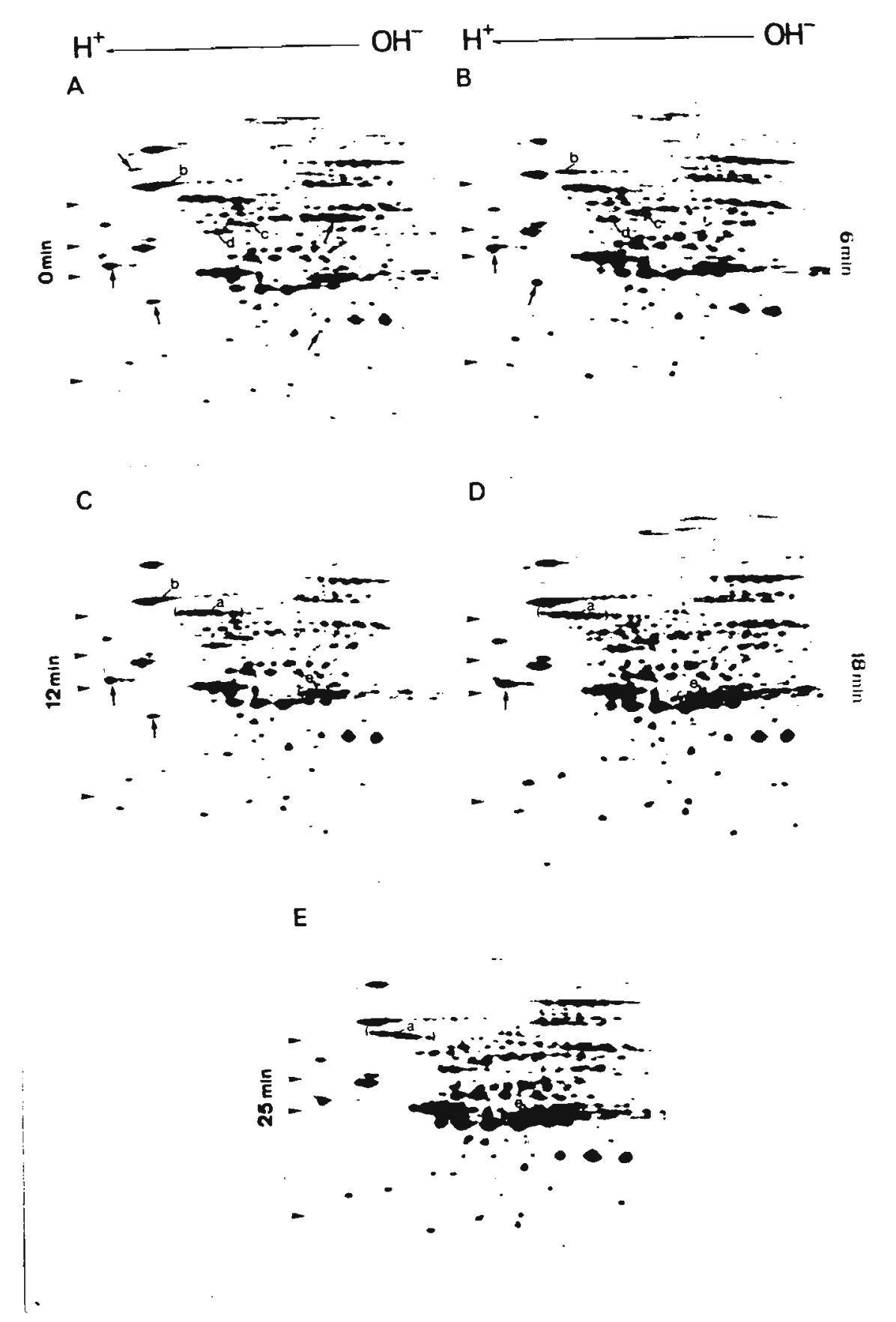

Figura 19 - Modificaçães pós-tradução de proteinas de zoósporos durante o inicio da germinaçao. Zoósporos obtidos após esporulaça sincrônica na presença de |3ss/metionina foram lavados para remogaro da metionina radioativa e induzidos a germinar em soluçăo inorgânica contendo metionina năo-radioativa $(0,2 \mathrm{mM})$. Foram retiradas amostras após 0 (A), 6 (B), 12 (C), 18 (D) e 25 (E) min da induçăo da germinaçăo e as proteínas foram analisadas através de eletroforese bidimensional IEF/5DS. As setas apontam proteínas que săo degradadas durante o inicio da germinaçao. As pontas de setas à esquerda dos auta-radiogramas representam os marcadores de peso molecular $(67,55,45$ e 25 $k D a$, de cima para baixo). 
112.
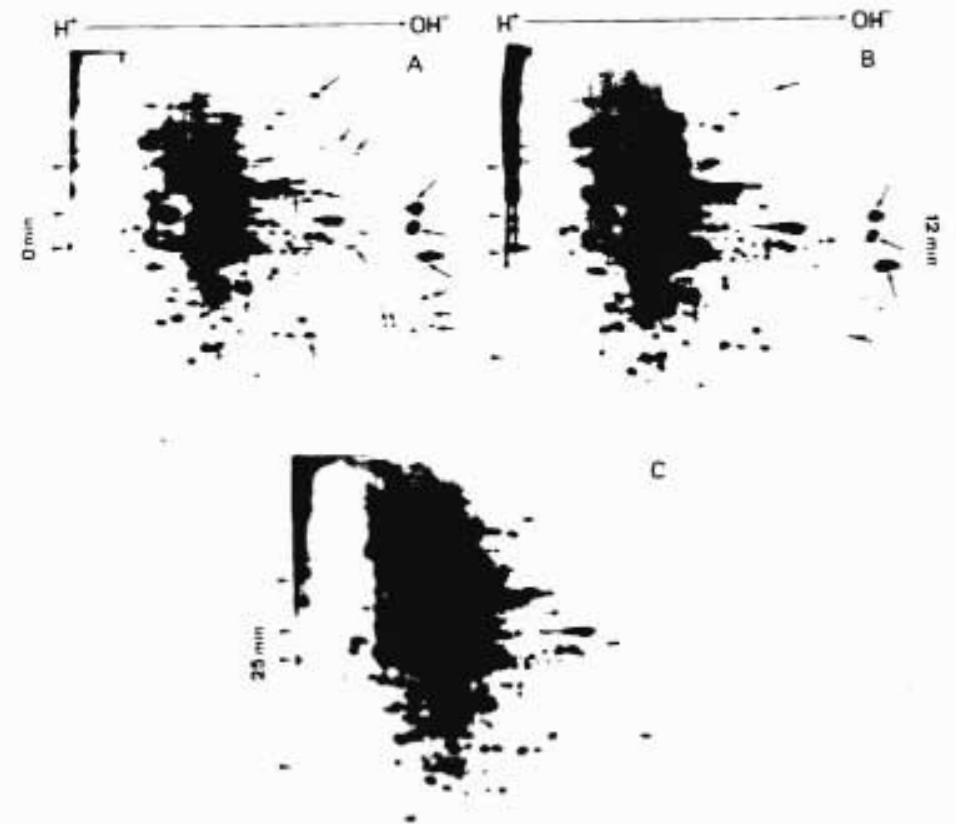

Figura 20 - Eletroforese bidimensional NEPHGE/SDS das modificaçoes de proteínas de zoósporos, pré-marcadas radioativamente. Como descrito na figura 19. 
113.

glicosilaço-desglicosilaggo ou outras capazes de afetar a carga elétrica de proteínas, podem estar ocorrendo durante o inf́cio da germinaça.

\subsubsection{Discuss\%o}

Durante a germinaço de zoósporos de B.emersonii ocorre uma grande estimulaço da síntese proteica. Como já foi demonstrado, menos que $10 x$ dos ribossomos dos zoósporos estao associados em polissomos, mas após $30 \mathrm{~min} d a$ germinaçao este valor aumenta para $80 \%$ (Gong e Lovett, 1977; Silverman et al.; 1974). D pequeno efeito da actinomicina D na sintese proteica Cleaver e Lovett, 1974; Silverman et al., 1974; Soll e Sonneborn, 1971a; Fig.12A) e na formacgo de polissomos (Leaver e Lovett, 1974; Silverman et al., 1974) durante o início da germinaçro sugeria que os zoósporos continham mRNAs. pré-formados. Hssim, a traduça destes mRNAs é que seria responsável pelo aumento da síntese proteica verificado entre os primeiros 15 e $30 \mathrm{~min}$ da germinaçao. De fato, como revelaram nossos resultados, o padra das proteínas sintetizadas até os 25 min de germinaçăo năo sofre alteraçớes qualitativas, indicando que - aumento na velocidade de síntese proteica que ocorre no inicio da germinaço é devido a um aumento da traduço das mesmas espécies de mRNA e nao de espécies diferentes. Além disso, como o padryo das proténas sintetizadas na ausência ou presença de actinomicina $D$ é idêntico e como todos os 
produtos da traduçăo "in vitro" do RNA de células de 20 min de germinaça foram encontrados entre os produtos da tradução "in vitro" do RNA dos zoósporo, confirmamos que o aumento da velocidade de sintese proteica é devido exclusivamente a uma gradual ativaça de mRNAs armazenados nos zoósporos, não havendo síntese de novas mensagens nos tempos inciais da germinaça. Vários outros fungos que no estágio de esporo săo inativos com relaçăo à síntese proteica contém RNA armazenado que é ativado durante a germinaf̧a dos seus esporos. Contudo, não é conhecido em que etapa (iniciaçăo ou elongaçăo) a sintese proteica está bloqueada nos esporos (Freer e Van Etten, 1978; Smith e Burke, 1979; Linz e Orlowski, 1982).

Após os $25 \mathrm{~min} d a$ induçăo da germinaçăo ocorreram várias modificaçăes no padrăo de sintese proteica, que correspondem ao surgimento de novas proteínas bem como à diminuição na velocidade de síntese de várias proteínas. A maioria das novas proteinas tem sua sintese dependente da transcrição de novas mensagens, uma vez que a actinomicina $D$ foi capaz de inibir o aparecimento destas novas proteinas. Esta ativação gênica que ocorre após os 25 min de germinaçăo foi confirmada pela deteção de novos produtos de traduça "in vitro" ao analisarmos o padra das proteinas sintetizadas "in vitro" a partir de RNA isolado de germes de 45 min. Contudo, existe um pequeno número de novas proteínas cuja síntese nåo é inibida por actinomicina D. A síntese tardia dessas proteinas, cujos mRNAs estavam armazenados nos 
zoosporos, sugere que a ativaço da traduço para alguns dos mRNAs estocados é seletiva, o que implica na existencia de uma regulaça ao nível do recrutamento dos mRNAs para a síntese destas proteínas. O recrutamento seletivo de alguns mRNAs maternos também ocorre durante a fertilizaça de ovos de ouriço do mar (Wells et al., 1981), durante a maturaçao de obcitos de estrela-do-mar (Rosenthal et al., 1982) ou durante o desenvolvimento de volvox em resposta a luz (Kirk e Kirk, 1985).

Assim, durante a germinaçăo dos zoósporos de B.emersonii parecem estar ocorrendo múltiplos níveis de regulaçao da sintese proteica, envolvendo tanto controles ao nível da tradução como da transcriçăo. Superposto à ativaçăo da traduça dos mRNAs pré-formados existe um controle para a seleça destas mensagens. A traduçăo poderia ser controlada tanto ao nivel da disponibilidade de mRNAs como pela própria atividade dos componentes da maquinaria de traduça. Existem algumas evidências de que parte da maquinaria de traduça dos zoósporos está interrompida ao nível da elongaça (Jaworski e Stumhofer, 1984). Além disso, particulas inibidoras da traduçăo (Jaworski e Stumhofer, 1983) bem como um inibidor de baixo peso molecular (Adelman e Lovett, 1974) já foram encontrados em zoósporos. Tanto adenilaça como desadenilaçăo de mRNAs pré-formados ocorrem simultaneamente durante a germinaçăo dos zoosporos e experimentos com actinomicina $\square$ demonstraram que transcriçăo năo é essencial para a poliadenilaçăo dos mRNAs dos zoósporos (Jawarski, 
116.

1976). Portanto, mudanças no estado de poliadenilaçăo dos mRNAs estocados poderiam estar relacionadas com esta seletividade da traduçăo.

Estudos preliminares sobre as proteinas sintetizadas na ausência e presença de actinomicina $D$ foram feitos por Lovett (1983). Foram detectados um total de 132 polipeptídios em géis bidimensionais com minimas variaçós no padrao de sintese. Contudo, este autor na descreveu as condiçases de preparaça do extrato das células - há uma evidente proteólise mostrada em seus géis - nem as candiçós de eletroforese, para que pudéssemos fazer uma comparaço direta com nossas resultados. Por outro lado, nossos resultados concordam com as conclusâes de Jahnson e Lovett (1984b) que, baseados em análises de hibridizaça de RNA/DNA em soluçăo, mostraram que células induzidas a germinar em soluçao inorgânica apresentam uma pronunciada perda dos mRNAs dos zósporas das classes de média e alta abundância, com um ligeiro enriquecimento da classe de baixa abundancia. Contudo, esta comparaçăo torna-se difícil, pois a técnica de eletroforese bidimensional, por nós utilizada, permite apenas a deteç̧a de proteínas codificadas pelos mRNAs das classes de intermediária e alta abundância.

Em paralelo ao aumento da sintese de proteinas durante o inicio da germinaçăo, observamos a degradaça de alguns polipeptídios que haviam sido sintetizados durante a esporulaçăo e continuavam presentes nos zoosporos. Junto à essa degradação especifica para alguns polipeptídios, outros 
117.

sofrem modificaçôs na sua carga, sugerindo que modificaços pós-traduçăo tais como proteólise, fosforilaçăo ou glicosilaçăo, podem ter um papel importante nos primeiros minutos da germinaçăo, durante o encistamento (transiçăo de zoósporo para célula redonda), já que esta transiçăo envolve rearranjos radicais na morfologia das células e ocorre mesmo na presença de cicloeximida. 
118.

\subsection{Identificaçă de três proteinas cuja sintese é controlada pelo desenvolvimento: actina, a-tubulina e $\beta$-tubulina}

Como continuidade dos estudos sobre a regulaça da síntese proteica durante a esporulaça e a germinaçăo de Blastocladiella optamos pela identificaça e caracterizaça de algumas proteinas cuja sintese fosse controlada pelo desenvolvimento. Dentro desta abordagem, obtivemos evidencias de que uma das proteínas induzidas durante um certo intervalo da esporulaçăo que foi denominada proteina n50 corresponde a uma proteina de choque térmico (Hsp>0) como será apresentado adiante no item III.2.3.. Com o objetivo de identificar outras proteinas, utilizamos anticorpos monoclonais comerciais contra actina, a $a$ tubulinas de galinha, na tentativa de detectarmas estas proteínas nos perfis eletroforéticos bidimensionais das proteinas totais de Blastocladiella através da técnica de "immunoblotting".

Inicialmente, havia necessidade de verificarmos se estes anticorpos, embora heterólogos, reconheceriam as proteínas equivalentes de B.emersonii. Assim, o extrato total de zoósporos foi submetido à eletroforese unidimensional e as proteínas, assim separadas, foram transferidas para filtros de nitrocelulose. Após a transferência, os filtros foram entro incubados com cada um dos anticorpos monoclonais. Na Fig.21 podemos verificar que 
119.

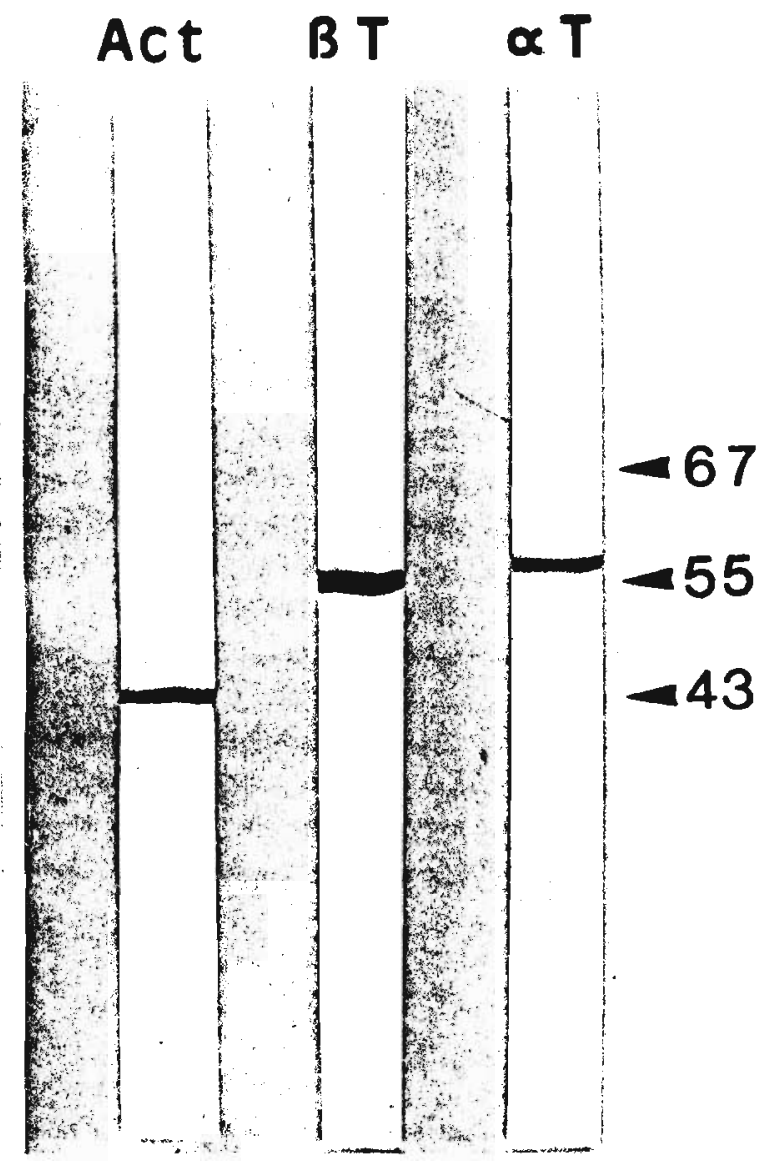

Figura 21 - Imunodeteç̧ão de actina, a e $\beta$-tubulinas no extrato total de proteínas de zoósporos. Após separacaro através de eletroforese unidimensional, as proteinas totais de zoósporos foram transferidas para filtro de nitrocelulose e submetidas à imunorreaço com anticorpos monoclonais antiactina (act), anti-a-tubulina $(\alpha-T)$ e anti- $\beta$-tubulina $(\beta-T)$. - complexo antígeno-anticorpo foi revelado imunoenzimaticamente através de reaçăo de diaminobenzidina e $\mathrm{H}_{2} \mathrm{O}_{2}$ com peroxidase conjugada a anti-IgG de coelho. As setas representam os marcadores de peso molecular em kDa. 
todos os trés anticorpos utilizados, anti-actina, anti-a-

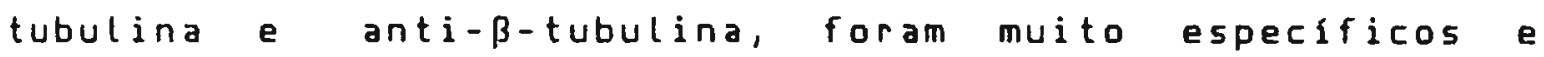
capazes de reconhecer uma única proteína de 43 kDa no caso do anti-actina, uma proteína de 56 kDa no caso do anti-atubulina e uma proteína de $55 \mathrm{kDa}$ no caso do anti- $\beta-$ tubulina.

Uma vez verificado que os anticorpos estavam reconhecendo actina e a e $\beta$-tubulinas, prosseguimos na deteçro destas proteínas num perfil eletroforético bidimensional. Para isso, as proteínas totais de células, marcadas com lass/metionina no intervalo $90-120 \mathrm{~min}$ da esporulação, foram submetidas à eletroforese bidimensional no sistema IEF/SDS e posterior transferéncia. Foram feitos quatro géis idênticos, os quais foram submetidos à transferência simultaneamente. 0 primeiro "blot" foi incubado com o monoclonal anti-actina, o segundo com o monoclonal anti-a-tubulina, o terceiro com o monoclonal anti- $\beta$-tubulina e o quarta com uma mistura dos trés anticorpos. A Fig.22A mostra o "blot" que foi incubado com a mistura dos três anticorpos e a Fig.22B mostra o autoradiograma correspondente. Assim, foi possível identificar: a) duas isoformas da actina com peso molecular de $43 \mathrm{kDa} e$ ponto isoelétrico aproximado entre $5,7-5,9$; b) uma banda múltipla, contendo pelo menos 3 isoformas de 55 kDa, correspondente à $\beta$-tubulina, migrando entre os pHs 5,8-6,0; c) uma banda de $56 \mathrm{kDa}$, correspondente à a-tubulina, migrando numa posiça mais básica que a $\beta$-tubulina cpi entre 
A

B

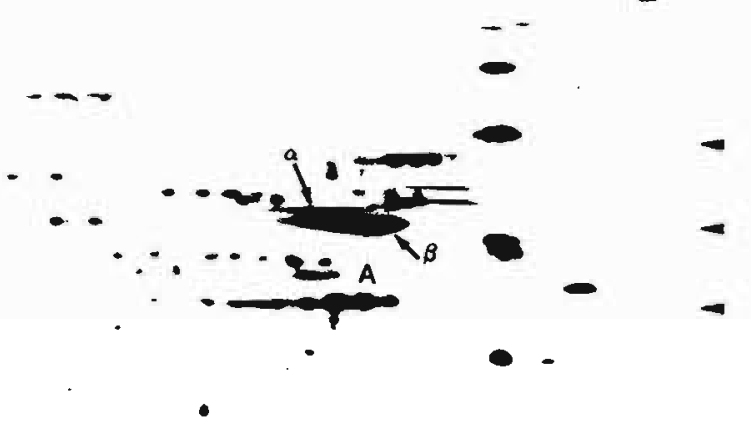

Figura 22 - Identificação de actina, $\alpha$ e $\beta$-tubulinas em gel bidimensional. Proteínas totais marcadas com jas/metionina durante o intervalo 90-120 min da esporulaçăo foram submetidas à eletroforese bidimensional IEF/SDS e transferência. 0 "blot" foi incubado simultaneamente com anti-actina, anti-a-tubulina e anti- $\beta$-tubulina e após incubaça, procedeu-se a revelaç̧o imunoenzimática dos complexos antígeno-anticorpo (A). Em (B) está mostrado o auto-radiograma do "blot", após fluorografia . As setas à direita (lado ácido do "blot") representam os marcadores de peso molecular (67, 55, $43 \mathrm{kDa}$, de cima para baixo). Está apresentada apenas parte do "blot" e do auto-radiograma correspondente. 
$6,0-6,1)$. o auto-radiograma (Fig.22B) mostra que estas trés proteinas estao sendo sintetizadas, com grande intensidade durante o intervalo $90-120 \mathrm{~min} d a$ esporulaçăo. Essas 3 proteínas já haviam sido numeradas na análise que fizemos das proteínas sintetizadas na esporulaçao (ítem III.1.1, Figs.2 e 4). Assim, actina corresponderia às proteinas 61/62, a-tubulina à proteína 43 e $\beta$-tubulina à proténa 38 (compare Figs.2 e 22 ).

Rbe e Lovett (1982), utilizando eletroforese unidimensional em gel de uréia, detectaram a existência de dois tipos de tubulinas ( $a$ e $\beta$ ) numa preparaça purificada de axonemas flagelares de zoósporos, porém uma única banda de 55 kDafoi visualizada após eletroforese desta mesma preparaça em gel de poliacrilamida 10\%/505. Através de eletroforese bidimensional e "immunoblotting", nós identificamos, em uma preparaça de axonemas flagelares de zoósporos, isolados como descrito por Rbe e Lovett (1982), uma banda proeminente de $55 \mathrm{kDa}$, que reagiu com anti- $\beta$ tubulina e um polipeptidio de $56 \mathrm{kDa}$, que reagiu com anti-atubulina (Fig.23). Portanto, anticorpos monoclonais contra tubulinas de microtúbulos de cérebro de galinha reagiram com tubulinas de microtúbulos de flagelos de zoósporos. Além disso, a e $\beta$-tubulinas, purificadas dos flagelos, comigram em eletroforese bidimensional com as proteinas que identificamos como sendo a e $\beta$ - tubulinas (nåo mostrado). 
123.

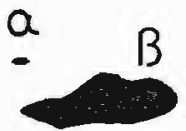

\footnotetext{
Figura 23 - Imunodeteç̧a de proteínas purificadas de flagelo de zoósporos. Tubulina purificada de flagelos foi submetida a eletroforese bidimensional IEF/SDS e transferência. "blot" foi incubado com anti-a-tubulina e anti- $\beta$-tubulina e o complexo antígeno-anticorpo foi detectado como descrito na figura 21. Rs setas a direita ( $a d o$ ácido do "blot") representam os marcadores de peso molecular (67 e 55 kDa, de cima para baixo). Está apresentada apenas parte do "blot".
} 
1.3.1. Variaço no acúmulo de actina, $\alpha$ e $\beta$-tubulinas durante o ciclo de vida de B.emersonii

Para investigar a quantidade de actina, $\alpha$ e $\beta$-tubulinas presente nas células nos diferentes estágios do desenvolvimento, utilizamos "immunoblots" de géis unidimensionais de proteinas totais isoladas de células de diferentes fases do ciclo de vida. Como mostrado na Fig.24A, células vegetativas contém menor quantidade de actina, sendo observado um acúmulo progressivo desta proteina durante a esporulaçăo, apresentando-se em níveis máximos em células de $180 \mathrm{~min}$. A actina é mantida nos zoósporos, sendo que após 2 horas de crescimento ocorre um decréscimo sensível nos seus níveis. Tanto a e $\beta$-tubulinas apresentaram níveis máximos após 120 min de esporulaçă, sendo que durante a germinaço e inicio do crescimento verifica-se uma rápida diminuiçăo na quantidade destas proteinas (Fig.24B, C).

1.3.2. Regulaça da síntese de actina, a e $\beta$-tubulinas durante a esporulaça

De acordo com a análise apresentada no ítem III.1.1. (Fig. 4), as proteínas agora identificadas como actina, a e ß-tubulinas apresentam estágios definidos de sintese máxima. Na Fig. 25 pode ser vista, em destaque, a variaço na síntese dessas proteínas ao longo da esporulaçăo. Durante a esporulação ocorrem mudanças dramaticas no padrăo de síntese 


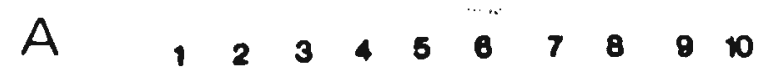

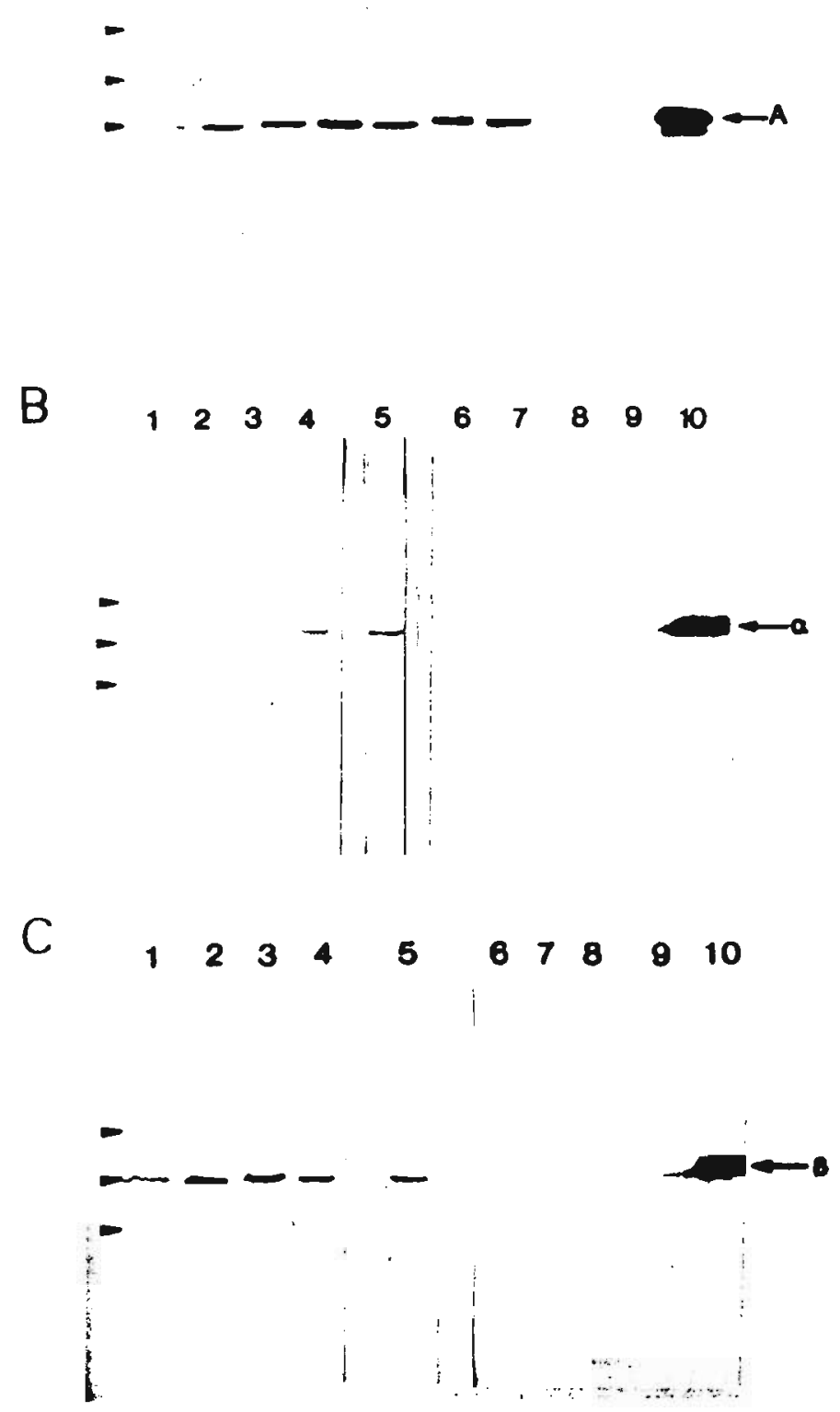

Figura 24 - Acúmulo de actina, a e $\beta$-tubulinas durante o ciclo de vida. Proteínas totais isoladas de células após 0 $\begin{array}{lllll}(1), 60 & \text { (2) } 120 & \text { (3) e } 180 & \text { (4) } m i n d a \text { induggo da }\end{array}$ esporulaçăo; zoósporos (5); germes de 45 min obtidos em solução inorgânica ( 6$)$ e células após 60 ( 7$), 120$ ( 8 ) e 180 (9) min de crescimento em meio nutriente $\mathrm{AL}$, foram separadas em eletroforese unidimensional e submetidas à transferência. 05 "blots" foram incubados com anti-actina ( $A$ ), anti-atubulina (B) e anti-ß-tubulina (C) e a revelaça foi feita como descrito na figura 21. No géis foram aplicadas a mesma quantidade $(15 \mu g)$ de proteínas totais de cada tipo celular. Canaletas: 10R, actina purificada de músculo de coelho; 10B e 10C, tubulina purificada de flagelo. 


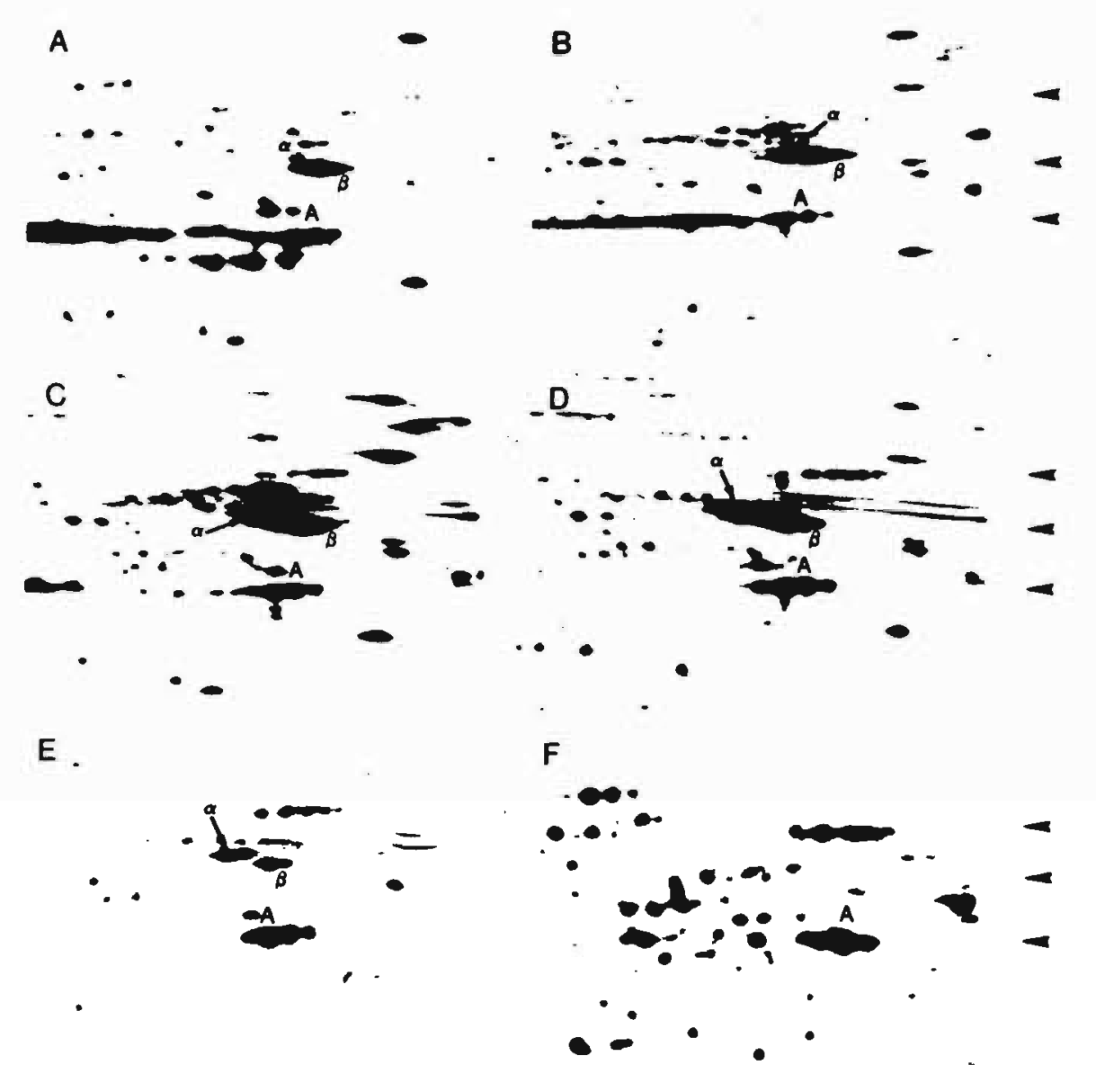

Figura 25 - Sintese "in vivo" de actina, a e $\beta$-tubulinas durante a esporulaçao. As células foram marcadas com |3es/metionina por periodos de $30 \mathrm{~min}$, tratadas com TCA e as proteinas totais submetidas a eletroforese bidimensional IEF/SDS. Sgo mostrados os auto-radiogramas dos géis correspondentes as proteínas sintetizadas durante os

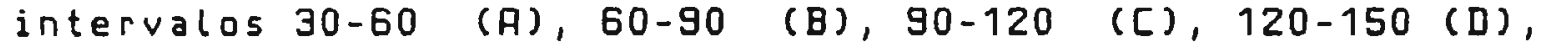
150-180 (E) e 180-210 (F) min após induçăo da esporulaçăo. As setas a direita (lado acido do gel) representam os marcadores de peso molecular $(67,55,43 \mathrm{kDa}$, de cima para baixol. Está apresentada apenas parte de cada autoradiograma. 
de proteínas totais, sendo marcantes as variaçoses na velocidade de sintese da actina a e $\beta$-tubulinas. A actina apresentou sintese máxima a partir dos 120 min da esporulação. A sintese de $a$ e $\beta$-tubulinas aumentou, significativamente, após $90 \mathrm{~min}$ da induçăo da esporulaçăo, verificando-se uma dimuiça nesta síntese máxima apás 150 min. E interessante observar que o aumento da velocidade de sintese para estas duas proteínas antecede por alguns minutos o início da formaça do flagelo dos zoósporos (Lovett, 1975).

A coloraçăo com azul de coomassie de géis bidimensionais de proteinas marcadas revelou que actina é uma das três proteínas mais abundantes em B.emersoni i cnăo mostrado).

Para comparar a cinética da sintese "in vivo" de actina, a e B-tubulinas com o acúmulo de seus mRNAs correspondentes, analisamos os produtos da tradução "in vitro" de RNAs poli(A)+, isolados durante as diferentes fases da esporulação (Fig.26). Pode ser observada, nesta figura, a ocorrência de um aumento na quantidade do RNA que codifica para actina, durante os estágios finais da esporulaçăo, indicanda que as variaçóes da velocidade de sintese "in vivo" desta proteina reflete o aumento nos níveis do seu RNA mensageiro. Estes estudos de traduçao "in vitro" também revelaram que o aumento, verificado "in vivo", da sintese das tubulinas $f$ lagelares, é devido a um aumento nos níveis dos mRNAs que codificam para estas proteínas. 


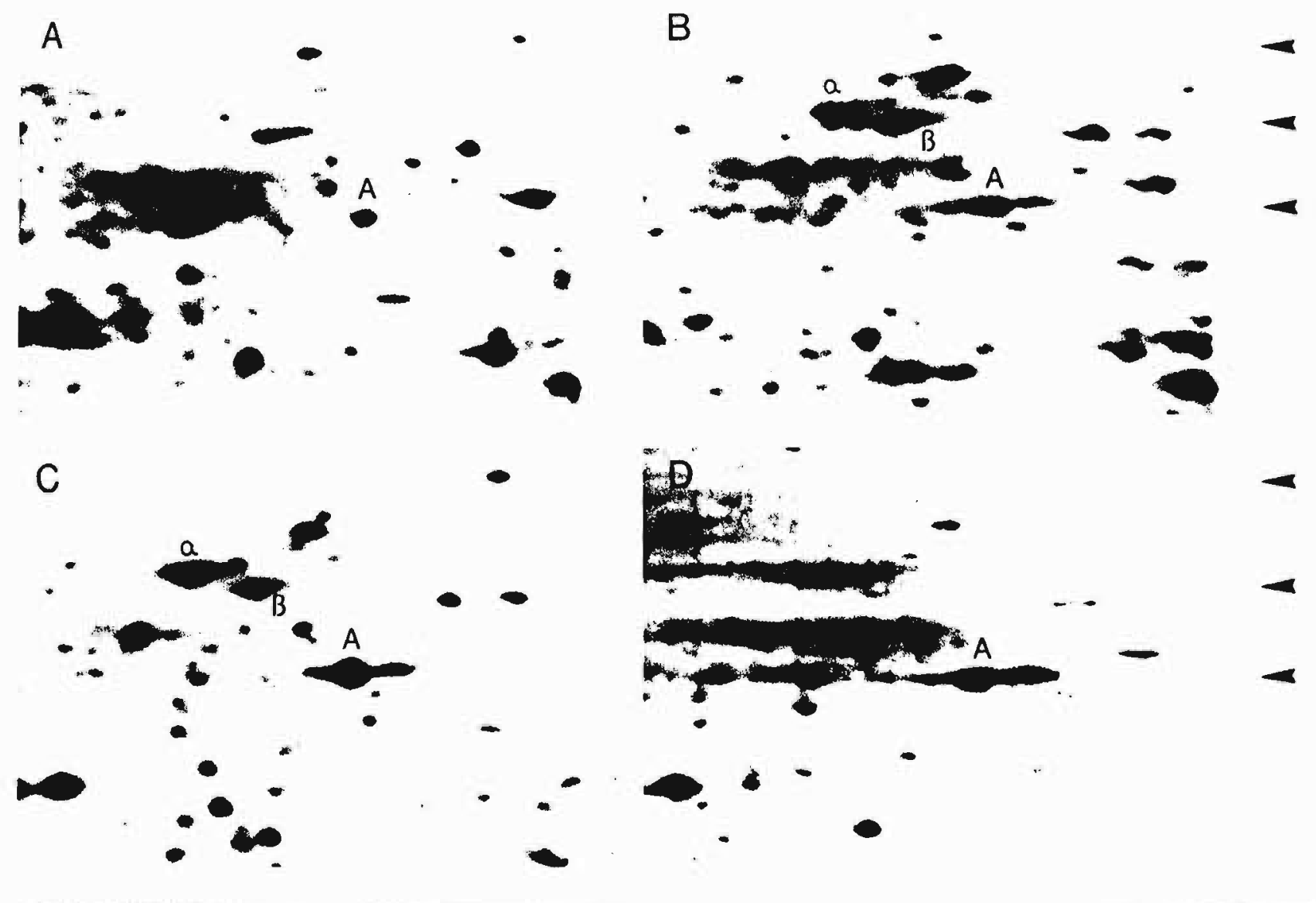

Figura 26 - Sintese "in vitro" de actina, a e $\beta$-tubulinas a partir de mRNAs poli( $(A)+$ isolados durante a esporulaça. mRNAs poli(A)* isolados de células após 0 (A), 60 (B), 120 (C) e 180 (D) min apás indução da esporulaçăo foram traduzidos "in vitro" em lisado de reticulócitos e os polipeptidios resultantes foram separados atraves de eletroforese bidimensional IEF/5D5. As setas à direita (lado ácido dos auto-radiogramas) representam os marcadores de peso molecular ( $67,55,43 \mathrm{kDa}$, de cima para baixo). Está apresentada apenas a regia de interesse de cada autoradiograma. 
Para identificar, nos géis bidimensionais, actina e tubulina entre os produtos de traduça "in vitro", uma pequena quantidade de extrato total da célula (ngo marcado) foi misturado aos produtos da reaçăo de traduçăo "in vitro", previamente à eletroforese bidimensional. Após "immunoblotting", pode ser visualizado no "blot" o padra caracteristico da actina e tubulinas proprias do lisado de reticulocitos, juntamente com o padra tipico destas proteínas em Blastocladiella, uma vez que a actina e tubulina de reticulócitos e de Blastocladiella apresentam diferentes mobilidades eletroforética em gel bidimensional.

Nossos resultados de marcaçăo "in vivo" revelaram a existência de pelo menos duas formas da actina, diferindo ligeiramente no ponto isoelétrico. Estas duas formas foram também detectadas quando RNA de células esporulantes foi traduzido "in vitro", sugerindo que esta heterogeneidade para actina de Blastocladiella pode ser devida a eventos pós-transcricionais ou a existencia de múltiplos genes para actina. 0 aumento na sintese de $\beta$-tubulina, durante a esporulaça, também é marcado pelo aparecimento de pelo menos três isoformas de $\beta$-tubulina, como detectado pela reação imunológica. Contudo, apenas uma única forma apresentando uma pequena cauda, correspondente a $\beta$-tubulina, foi detectada entre os produtos de traduça "in vitro", sugerindo, assim que eventos ao nível de pós-traduçăo podem estar determinando o aparecimento das isoformas de $\beta$ tubulina. 
130.

Tanto actina com a e $\beta$-tubulinas parecem ngo ser sintetizadas durante a germinaçăo. [ontudo, actina é sintetizada, aparentemente em menor quantidade, no crescimento tardio (ver Fig.2A). Nă podemos excluir a possibilidade da existência de outros tipos de tubulina existentes em Blastocladiella, os quais năo estariam sendo reconthecidos pelos anticorpos monoclonais usados.

\subsubsection{Discussaัo}

Acompanhando as dramáticas mudanças morfológicas que ocorrem durante a esporulação, verificamos um intenso aumento na síntese e no acúmulo de actina $e$ de $a$ e $\beta$ tubulinas. As tubulinas, proteínas estruturais predominantes nos microtúbulos do $f$ lagelo de zoósporos, săo sintetizadas "de novo", entre 90-150 min após a induçăo da esporulaçăo sendo acumuladas simultaneamente; esta variação coincide com a zoosporogênese. A velocidade de sintese de actina, sofre um aumento após 90-120 min do inicio da esporulaça, permanecendo elevada até o final deste processo, sendo que o acúmulo de actina reflete este aumento de sua sintese. D controle do desenvolvimento, para a sintese de actina e tubulinas, parece ser exercido a nivel do acúmulo dos seus respectivos RNAs mensageiros. A sintese, tanto das duas isoformas da actina bem como das isoformas de $\beta$-tubulina de Blastocladiella, é aparentemente coordenada durante a esporulaçăo. Os resultados de traduçăo "in vitro" sugerem 
que a heterogeneidade da actina é devida a eventos póstranscricionais ou múltiplos genes, contudo a ocorrencia de acetilaçăo de actina no ensaio de traduçăo "in vitro" năo pode ser excluida (Garrells e Hunter, 1979).

A germinaçăo dos zoósporos de B.emersonii envolve um rearranjo radical da arquitetura celular, que transforma os zoósporos em células redondas, que săo convertidas em germes, capazes de crescer. Entre estes rearranjos estruturais, está a retração do flagelo pelo corpo celular e a desmontagem do axonema $f$ lagelar (Lovett, 1975). Barstow e Lovett (1974) relataram evidências preliminares da presença de microtúbulos arranjados longitudinalmente nos rizóides de germes. A actina é mantida ao longo da germinaçăo e desaparece após 2 horas do crescimento, sugerindo o envolvimento de microfilamentos, na profunda reorganizaçăo das organelas típicas dos zoósporos. D niveis dos antígenos detectados com os monoclonais anti-tubulina de cérebro de galinha, revelaram o desaparecimento das tubulinas durante a germinaçăo, o que pode ser correlacionado com a desmontagem

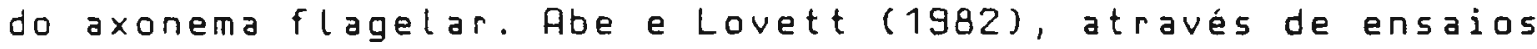
de ligação com colchicina, concluiram que, as tubulinas dos axonemas, após a retraçăo dos flagelos, naro retornam ao reservatório solúvel, detectado pelos ensaios com colchicina, e são provavelmente degradadas durante a germinaçăo. Apesar dos problemas que eventualmente ocorrem no ensaio de ligaça com colchicina, estes autores apresentaram evidências de que, as tubulinas dos axonemas 
flagelares podem ser diferentes da tubulina citoplasmática solúvel. Nós não podemos excluir, em nossos estudos, a possibilidade de que o monoclonal anti-tubulinas de cérebro nåo reconheça alguma tubulina citoplasmática diferente das tubulinas flagelares.

Ds anticorpos monoclonais desenvolvidos em camundongo, contra a e $\beta$-tubulinas de cérebro de galinha apresentaram reaça cruzada com as tubulinas isoladas do flagelo de zoósporos. Também, o anticorpo anti-actina de galinha reagiu com uma proteína similar em Blastocladiella, indicanda a existência de similaridades imunológicas entre estes polipeptídios, apesar da distancia filogenética entre fungos e vertebrados. Em vários organismos inferiores e plantas, a a-tubulina difere da tubulina de mamíferos, por migrar adiante da $\beta$-tubulina em géis de poliacrilamida/sDS (Clayton et al., 1980; White et al., 1983; Russell et al., 1984; Hussey e Gull, 1985). Em Blastocladiella, năoverificamos esta inversa entre a e $\beta$-tubulinas.

- fenômeno das múltiplas formas para actina e tubulinas ocorre mesmo nos eucariotos inferiores. A heterogeneidade eletroforética de a e $\beta$-tubulinas e actina já foi observada em S.pombe, Physarum, Dictyostelium, Polytonella, Chlamydomonas, Aspergillus e Crithidia (Clayton et al., 1979; Burland et al., 1983; Kindle e Firtel, 1978; Jantzen, 1981; Mkceithan et al., 1983; Sheir-Neiss et al., 1978; Russell et al., 1984), sendo que esta heterogeneidade pode ser detectada ao nivel de diferentes tipos celulares 
expressando diferentes isoformas, como ao nivel de organelas diferentes montadas a partir de isoformas distintas. Embora, a presença de certas isoformas possa ser devida às modificações ao nível de pós-traduçăo, elas podem, também, representar produtos expressos a partir de genes diferentes.

Vários dados da literatura relatam diferentes tipos de modificaçăo pós-traduçăo que determinam as isoformas das tubulinas. Em cérebro de rato, parece ocorrer fosforilaçăo da $\beta$-tubulina (Eipper, 1975) e tirosinilaçăo de $\alpha$-tubulina (Arce et al., 1975). Em Physarum polycephalum, uma nova forma de tubulina, isto é, tubulina acetilada é produzida quando a mixoameba é induzida a se tornar flagelada cGreen e Dove, 1984; Diggins e Dove, 1987). Em [hlamydomonas (L'Hernault e Rosenbaum, 1985) e em Crithidia fasciculata (Russell et al., 1984), foi detectada a existência de uma atubulina especifica de flagelos, que é produzida pela acetilaçåo da tubulina citoplasmática. Também, em Tetrahymena thermophila, foram identificadas diferentes formas de a e $\beta$-tubulinas no axonema ciliar, algumas das quais sa distintas das tubulinas citoplasmáticas solúveis (Suprenant et al., 1985). Assim, a adição ou a remoçăo de modificaçôes após a tradução como por exemplo a acetilaça de tubulinas poderia desempenhar um papel controlador para a montagem e a desmontagem do $f$ lagelo. Também as actinas podem ser modificadas, após a traduçăo, através de acetilaçăo ou acilaçăo (Rubenstein e Deuchler, 1979; Stadler et al., 1985). Resultados obtidos por nós (nå mostrados) 
demonstraram que fosforilaçă năo é a modificaça póstraduça que eventualmente seria responsável pelas múltiplas formas de actina e $\beta$-tubulina em Blastocladiella.

A heterogeneidade da actina e das tubulinas em alguns casos poderia ser devida à presença de múltiplos genes para estas proteínas. Em muitos organismos, $\alpha$ e $\beta$-tubulinas 5 ào codificadas por familias multigenicas (Cleveland e Sullivan, 1985), sendo que uma fraçăo dos genes destas famílias são pseudogenes. Enquanto leveduras contem um único gene de actina ( $N g$ e Abelson, 1980), outros eucariotos contém vários genes de actina como ouriço do mar que contém 11 (5cheller et al., 1981) e Dictyostelium que contém 17 (Kindle e Firtel, 1978). Contudo, não é conhecido quantos destes genes săo diferentes e quantos sรo, de fato, expressos. De qualquer maneira, está descrito que o nivel de expressaro dos genes de actina varia dramaticamente ao longo do ciclo de vida de Dictyostelium (Alton e Lodish, 1977; Marlgolskee e Lodish, 1980\} e que mudanças na expressăo dos genes de actina e tubulina parecem exercer algum papel durante o crescimento e a diferenciaça celular (Farmer, 1986; BenZe'ev, 1986). 
2. A resposta ao choque térmico em Blastocladiella emersonii

2.1. Expressao diferencial das proteinas de choque térmico durante o desenvolvimento

Para investigar a regulaça da resposta ao choque térmico durante o desenvolvimento de B.emersonii foi necessário, inicialmente, determinar qual a temperatura onde esta resposta seria melhor induzida. A figura 27 mostra o perfil eletroforético das proteinas totais sintetizadas apos - aquecimento de zoosporângios e germes em diferentes temperaturas. Tanto durante a esporulaça como durante a germinaçăo, observamos a induça de um novo grupo de proteínas, com pesos moleculares na faixa de 70-84 kDa e 45$60 \mathrm{kDa}$, quando as células foram transferidas de $27^{\circ} \mathrm{C}$ para 34. 36 ou $38^{\circ} \mathrm{C}$; estas proteinas correspondem às proteínas de choque térmico, Hsps (do inglês "heat shock protein"). A incorporaça de jas/metionina em Hsps aumenta gradualmente com a elevação da temperatura até $38^{\circ} \mathrm{C}$ e năo é acompanhada de uma diminuiça da síntese proteica normal. A $40^{\circ} \mathrm{C}$ observamos um decréscimo tanto na síntese das Hsps como das proteínas normais, indicando que o aquecimento das células a esta temperatura mais elevada afeta tanto a expressa das proteínas de choque térmico como das proteínas normais. D grupo de Hsps de menor peso molecular (30-17 kDa) tem uma faixa de induçă mais estreita, mas a máxima incorporaçăo ocorre também a $38^{\circ}[$, observando-se muito pouca incorporaçăo 
A

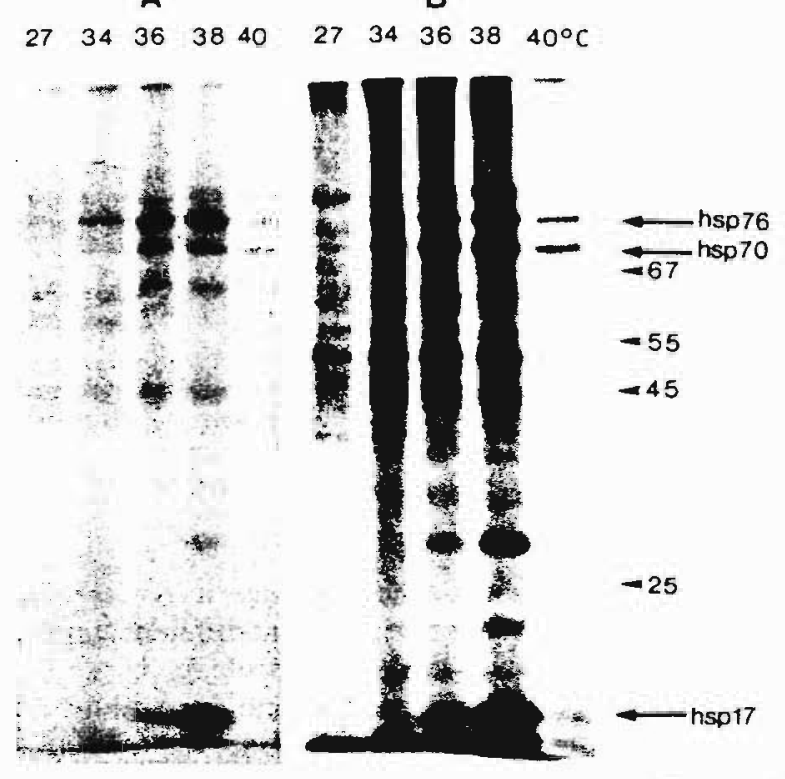

Figura 27 - Temperatura ótima para indução das proteínas de choque térmico. (A) Após $30 \mathrm{~min}$ de induça da esporulaçăo a $27^{\circ} \mathrm{C}$, as células foram incubadas nas temperaturas indicadas por $30 \mathrm{~min}$, |3s $5 /$ metionina foi adicionada e a incubaçăo foi mantida por mais $30 \mathrm{~min}$. (B) Após $15 \mathrm{~min}$ de induçăo da germinaçăo de zoósporos em soluçăo inorgânica a $27^{\circ}[$, as celulas foram incubadas por 35 min nas temperaturas indicadas e marcadas com lass/metionina nos $10 \mathrm{~min}$ finais da incubaçăo. Nos géis foram aplicadas quantidades equivalentes de proteínas. As pontas de setas representam os marcadores de peso molecular em kDa. 
em temperaturas imediatamente inferiores ou superiores a $38^{\circ} \mathrm{C}$. Assim, $38^{\circ} \mathrm{C}$ foi a temperatura onde a resposta ao choque térmico foi melhor induzida, sendo que em Blastocladiella a tradução das mensagens normais é aparentemente concomitante com o aumento da traduça dos mRNAs de choque térmico. Na figura 27 estaro indicadas as três proteinas mais proeminentes (Hsp76, Hsp70 e Hsp17); outras proteínas săo claramente induzidas, porém em menor extensa.

- exame das células ao microscópio ótico, após diferentes tempos de choque térmico, revelou que a germinaça, incluindo a formaçăo do tubo germinativo, năo foi afetada pelo aquecimento a $38^{\circ} \mathrm{C}$. Contudo, a $40^{\circ} \mathrm{C}$ os zoósporos encistam, mas năo formam tubo germinativo. 0 aquecimento a $38^{\circ} \mathrm{C}$ ou $40^{\circ} \mathrm{C}$, quando feito durante a esporulação, provocou um certo atraso no processo.

Utilizando eletroforese bidimensional, fizemos uma análise mais detalhada das proteinas induzidas pelo choque térmico a $38^{\circ} \mathrm{C}$ durante o crescimento e em várias fases da esporulaçåo e da germinaçăo.

Na figura 28 estão apresentados as perfis eletroforéticos bidimensionais das proteinas sintetizadas quando as células após 15 ou $30 \mathrm{~min}$ de indução da germinaçăo a $27^{\circ} \mathrm{C}$ foram transferidas para $38^{\circ} \mathrm{C}$ e mantidas nesta temperatura por 30 e 15 min respectivamente, isto é, as células foram coletadas após $45 \mathrm{~min}$ da induçăo da germinação. Pelo menos 11 polipeptidios foram induzidos em 
138.

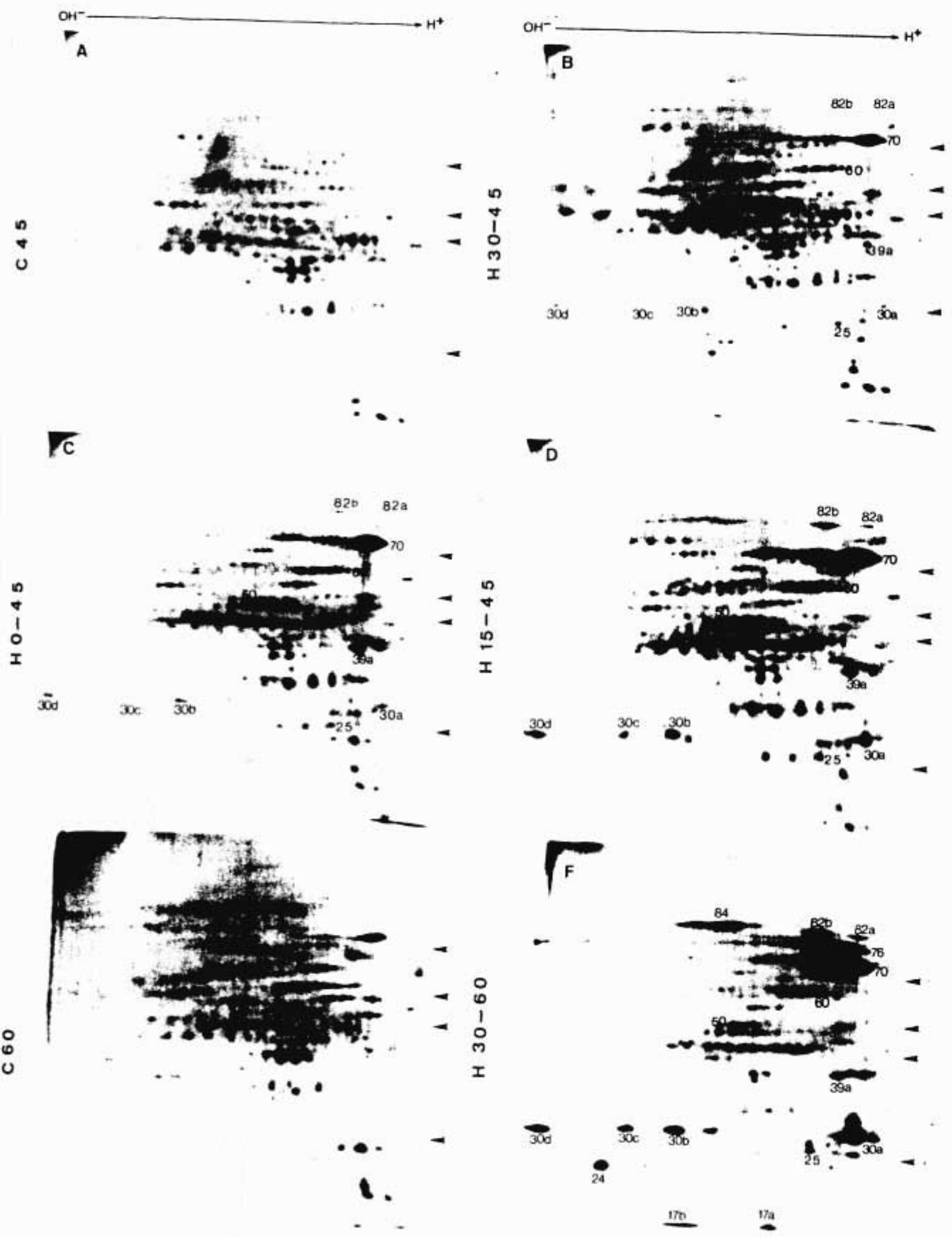

Figura 28 - Legenda na página seguinte 
139.

Figura 28 - Análise através de eletroforese bidimensional IEF/SDS da sintese de proteínas de choque térmico durante a germinação. Zoósporos foram induzidos a germinar em soluço inorgânica e submetidos ao tratamento térmico pelos períodos indicados $\left(B,[, D, F)\right.$ ou mantidos a $27^{\circ}[(A, E)$, como controle. Em todos os casos as células foram marcadas com jas/metionina nos $10 \mathrm{~min} f$ inais da incubacăo. As proteinas foram extraidas e submetidas a eletroforese. As setas à direita (lado ácido dos auto-radiogramas) representam os marcadores de peso molecular $(67,55,45$ e $25 \mathrm{kDa}$, de cima para baixo). 
ambos os casos: Hsp82a, Hsp82b, Hsp70, Hsp60, Hsp50, Hsp39a, Hsp30a, Hsp30b, Hsp30c, Hsp30d, Hsp25 (Figs.28B,D). Este mesmo conjunto de Hsps foi sintetizado quando os zoósporos foram induzidos a germinar diretamente a $38^{\circ} \mathrm{C}$ e coletados após 45 min (Fig.28[). Em todos os casos a j35 foi adicionada nos últimos $10 \mathrm{~min}(35-45 \mathrm{~min})$ da incubaça e a quantificaça da radioatividade incorporada em proteínas revelou que a incorporaçă foi ligeiramente maior a $38^{\circ}[$ que a $27^{\circ} \mathrm{C}$ (กรัo mostrado). Além disso, observamos que o choque térmico a $38^{\circ} \mathrm{C}$ กั̃o afetou o processo de germinaçăo, incluindo a formaçăo do tubo germinativo, mesmo quando o aquecimento foi iniciado no tempo zero da germinaça.

Ao analisarmos a resposta ao choque térmico na germinaçăo mais tardia, detectamos a induçăo de outro conjunto de Hsps em adiçăo àquele que foi induzido durante o choque térmico até $45 \mathrm{~min}$ de germinaçăo. Assim, células que foram transferidas para $38^{\circ} \mathrm{C}$ aos 30 min da germinaça e mantidas nesta temperatura por mais $30 \mathrm{~min}$, sendo a marcaça com lass/metionina feita nos $10 \mathrm{~min} f i n a i s$ da incubaga (50$60 \mathrm{~min})$, sintetizam mais um grupo de Hsps: Hsp84, Hsp76, Hsp24, Hsp17a e Hsp17b (Fig.28F). Estas proteínas năo foram induzidas quando o choque térmico foi analisado até $45 \mathrm{~min}$ da germinaçăo, independente do momento e da duraçăo do tratamento térmico ( $F i g s .28 B,[, D)$, sugerindo um controle do desenvolvimento para a sintese destas proteínas superposto à induçăo pelo choque térmico. 
Para análise da resposta ao choque térmico durante o crescimento, as células, após $120 \mathrm{~min}$ de crescimento a $27^{\circ} \mathrm{C}$, foram transferidas para $38^{\circ} \mathrm{C}$, mantidas nesta temperatura por 30 ou $60 \mathrm{~min}$, sendo a marcaça com lass/metionina feita nos últimos 10 min da incubação. Foram detectados 14 polipeptídios: Hsp82a, Hsp82b, Hsp76, Hsp70, Hsp60, Hsp50, Hsp45a, Hsp45b, Hsp45e, Hsp39a, Hsp30b, Hsp30d, Hsp25 e Hsp17b, induzidos após 30 ou $60 \mathrm{~min}$ de choque térmico, sendo a resposta melhor induzida durante o tratamento mais curto (Fig.29). A proteínas Hsp70 e Hsp8zb săo fortemente induzidas; várias outras Hsps, tais como Hsp76, Hsp30b, Hsp30d ou Hsp17b, săo fracamente marcadas quando comparadas com a indução obtida em outras fases do desenvolvimento. Durante o choque térmico observamos apenas um ligeiro decréscimo na síntese proteica normal. No crescimento à temperatura fisiológica duas proteinas, com pesos moleculares e pIs similares a Hsp82b e Hsp70, săo sintetizadas em níveis basais.

Durante as diferentes fases da esporulaça as células foram submetidas ao tratamento térmico de 30 ou $60 \mathrm{~min}$ de duraçăo. A marcaça com |3ss/metionina foi feita nos $20 \mathrm{~min}$ finais da incubação. Pelo menos 16 polipeptídios foram induzidos (Hsp84, Hsp82a, Hsp82b, Hsp76, Hsp7O, Hsp6O, Hsp45a, Hsp45b, Hsp45e, Hsp39b, Hsp39c, Hsp39d, Hsp30a, Hsp25, Hsp17a, Hsp17b) nos primeiros $30 \mathrm{~min}$ de choque térmico (Figs.30B,D,F). Quando as células săo expostas a alta temperatura por períodos mais prolongados (60 min), a 


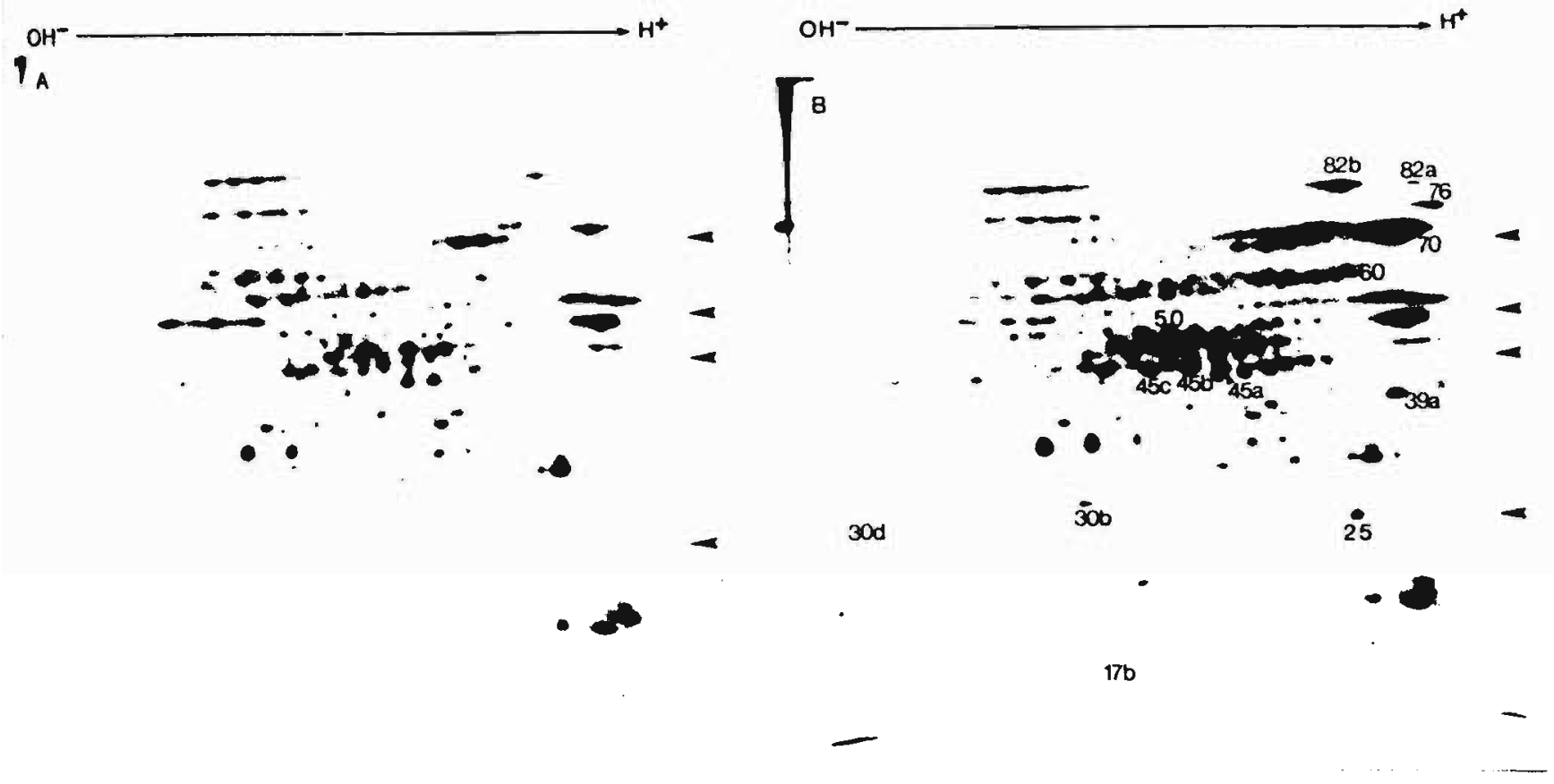

Figura 29 - Análise através de eletroforese bidimensional IEF/SDS da sintese de proteinas durante choque térmico em células em crescimento. Zoósporos foram induzidos a germinar a $27^{\circ} \mathrm{C}$ em meio nutriente RL. Após 2 horas de crescimento, uma aliquota de células foi transferida para $38^{\circ}[$ e mantida nesta temperatura por $30 \mathrm{~min}$ (B). Em (A) células mantidas a $27^{\circ} \mathrm{C}$, como controle. As células foram marcadas com |3s5|metionina nos $10 \mathrm{~min}$ finais da incubaça. As proteinas foram extraidas e submetidas a eletroforese. As setas à direita (lado acido dos auto-radiogramas) representam os marcadores de peso molecular $(67,55,45$ e $25 \mathrm{kDa}$, de cima para baixo). 
143.

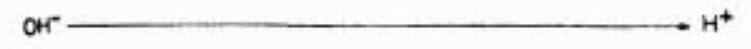

A
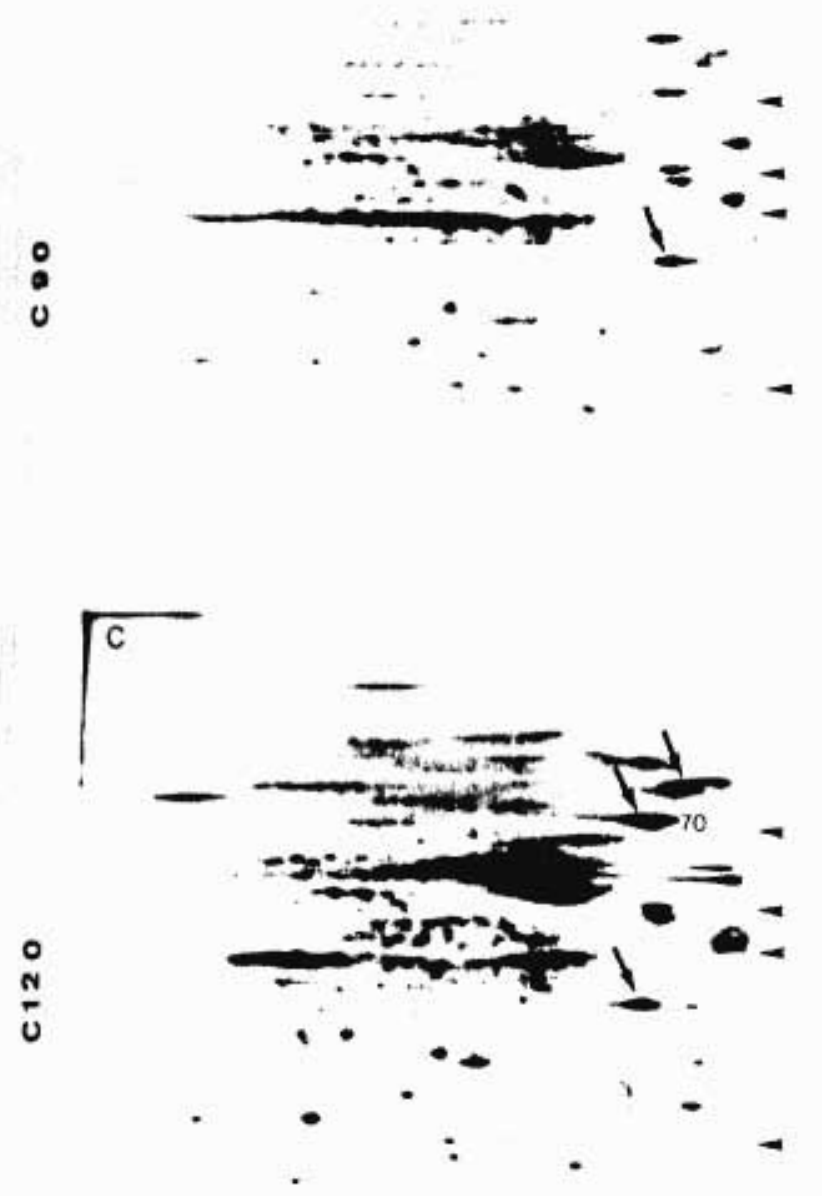

TE

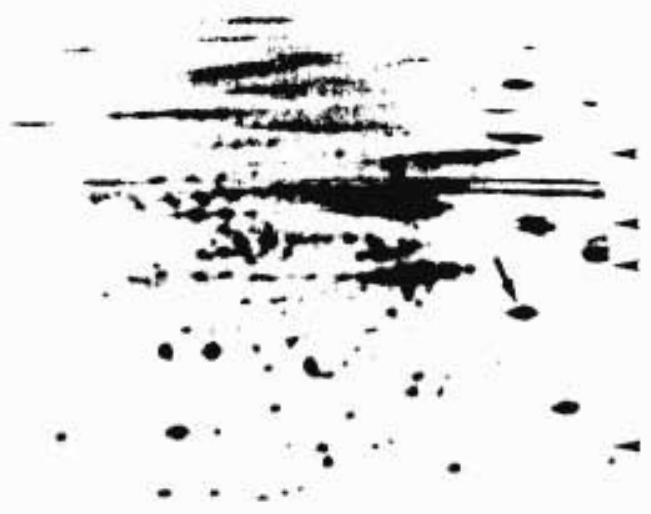

$17 b \quad 17 a$

D

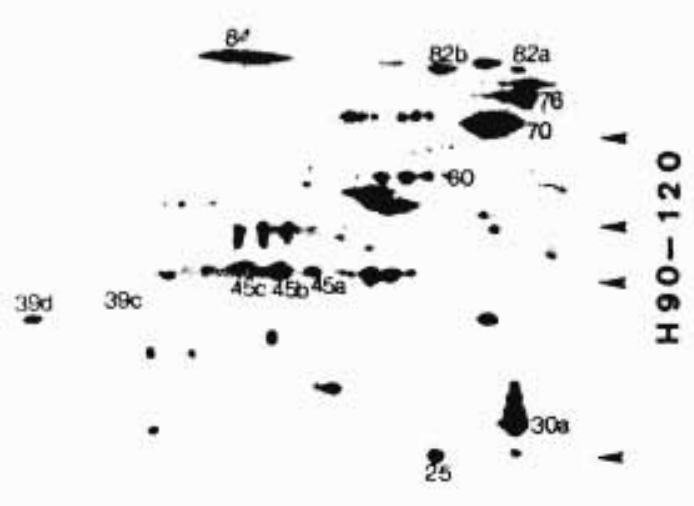

$170 \quad 173$
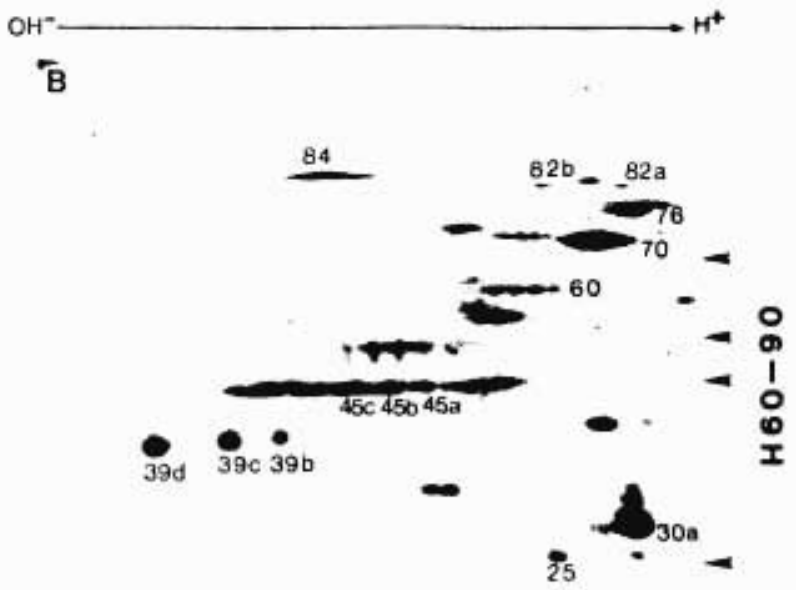

D

$r_{F}$

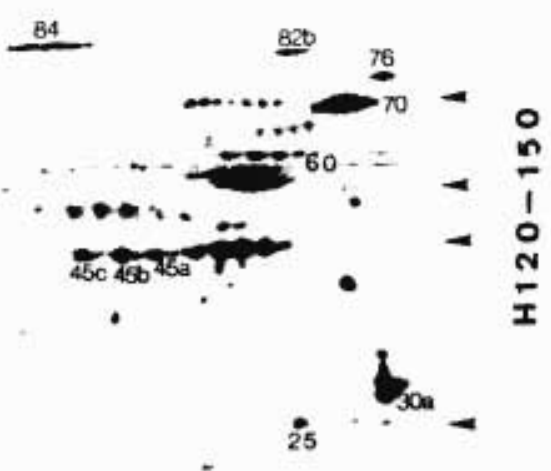

$\sum^{17 b} \quad 17 a$

Figura 30 - Legenda na página seguinte 
144.

Figura 30 - Padrôes de sintese proteica de células esporulantes normais e aquecidas. A esporulaçăo foi induzida a $27^{\circ} \mathrm{C}$ e durante os intervalos indicados aliquotas de células esporulantes foram submetidas a tratamento térmico a $38^{\circ}[(B, D, F)$. Em $(A, C, E)$ aro mostrados os controles. As células foram marcadas com las 5 |metionina nos 20 min finais da incubaça. As proteírias foram extraidas e submetidas à eletroforese bidimensional IEF/SDS. Hs setas apontam as proteinas de choque térmico induzidas espontaneamente durante a esporulaçăo. As pontas de setas à direita (lado ácido dos auto-radiogramas) representam os marcadores de peso molecular $(67,55,45$ e $25 \mathrm{kDa}$, de cima para baixo). 
síntese de várias proteinas de choque térmico diminui (Hsp84, Hsp39b, Hsp39c, Hsp39d), além de se observar um aumento da incorporaçăo de metionina em protelnas normais. Este fato sugere uma transitoriedade da resposta a choque térmico na esporulação.

A comparaçăo do padrăo das proteínas sintetizadas nos vários estágios da esporulaça à temperatura fisiológica com aquele induzido pelo tratamento térmico, revelou que três proteínas ( $39 \mathrm{kDa}, 70 \mathrm{kDa} e 76 \mathrm{kDa}$ ), sintetizadas a $27^{\circ}[$, parecem corresponder, respectivamente, as proteínas de choque térmico Hsp39a, Hsp70 e Hsp76, devido às suas similaridades em peso molecular e ponto isoelétrico (Figs.30R, $[, E)$. A proteina de 39 kDa é expressa constitutivamente ao longo da esporulaça a $27^{\circ}[$, enquanto as proteínas de $70 \mathrm{kDa} e 76 \mathrm{kDa} s$ ăo induzidas apenas aos 120 min deste processo. E interessante destacar que o choque térmico năo aumentou significativamente o nível de expressão destas duas proteinas naquele momento (Fig.30D). Já havíamos demonstrado que esta proteína de $70 \mathrm{kDa}$ (anteriormente designada $n^{\circ} 50$, item III.1.1.2), que apresenta migraçăo eletroforética similar a Hsp70, tem síntese máxima aos $120 \mathrm{~min}$ da esporulaçăo (Fig.4).

A análise da resposta ao choque térmico nas diferentes fases do ciclo de vida de B.emersonii permitiu, portanto, a identificaçăo, dentro das limitaçôes de resoluçăo oferecidas pela eletroforese bidimensional, de pelo menos 22 polipeptídios induzidos pela hipertermia. A tabela 1 resume 
TABELA 1. PROTEINAS DE CHDQUE TERMICO INDUZIDAS PELA HIPERTERMIA EM DIFERENTES FASES DO CICLO DE UIDR DE B.emersonii, IDENTIFICADAS POR ELETROFORESE BIDIMENSIONAL

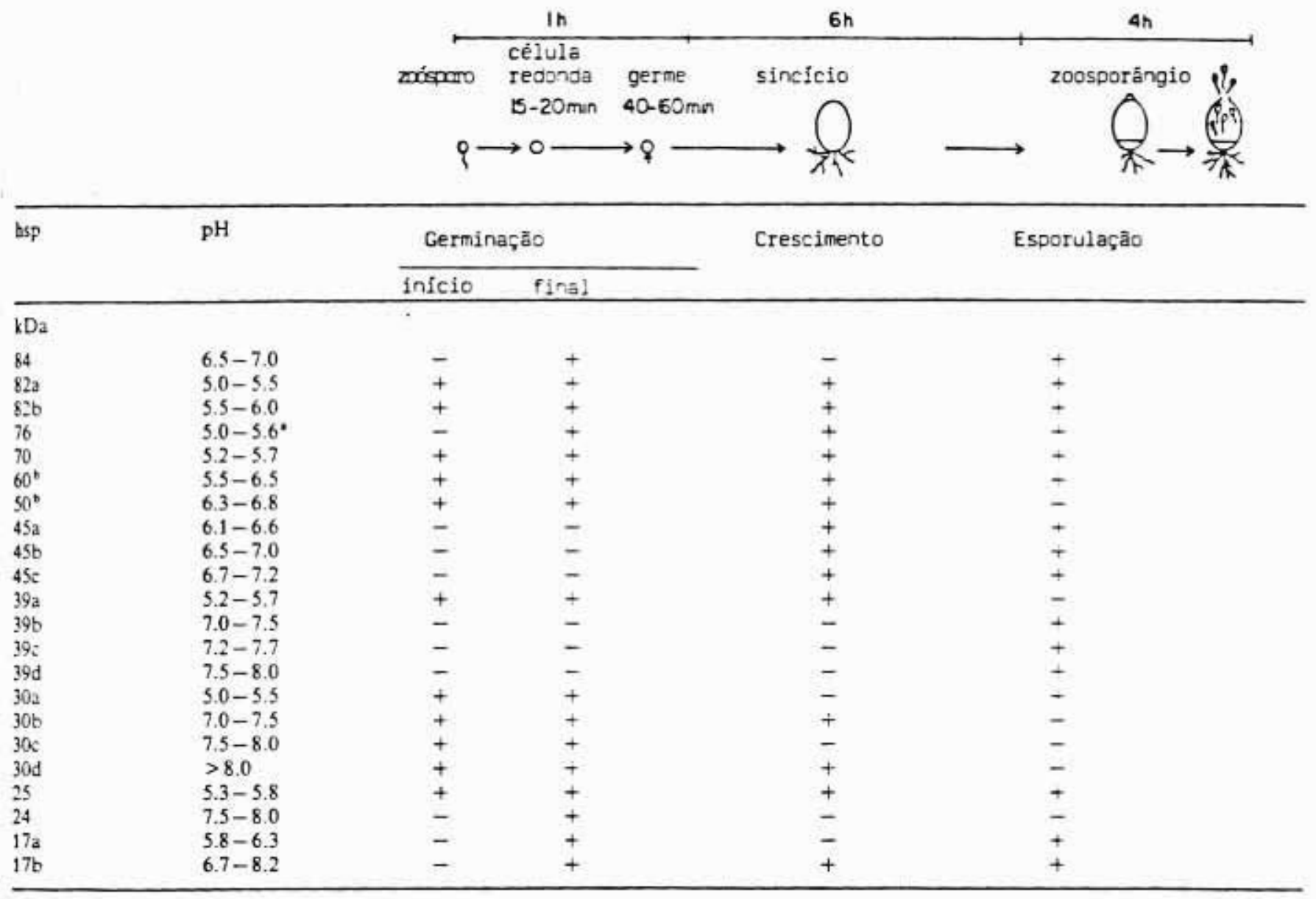

- Durante a esporulaçăo a Hsp76 apresenta-se em posiça mais ácida que a Hsp70, mas durante a germinaça ela é mais básica

- Estas proteínas correspondem a 2-5 polipeptídios nesta faixa de peso molecular 
a expressăo diferencial destas Hsps de acordo com o estágio de desenvolvimento, mostrando que, embora alguns polipeptidios ocorram em todas as fases do desenvolvimento, outros să característicos de uma fase especifica do ciclo de vida. As Hsps 82a, 82b, 76, 70, 60, 25 e 17b 5 ăo comuns à germinaça, crescimento e esporulaça, sendo a Hsp70 a proteína de choque térmico predominante em Blastocladiella. Hlgumas Hsps năo são induzidas durante o processo de germinaร̧วo ( $45 a, 45 b, 45 c, 39 b, 39 c, 39 d)$, enquanto a Hsp24 e a Hsp30e são proteinas típicas desta fase. Por outro lado, Hsps 39b, 39c, e 39d săo típicas de esporulaçăo.

A regulaçăo da expressăo gênica durante a esporulaçăo ocorre principalmente ao nivel da transcriça citem III.1.1.4), enquanto durante o início da germinaçao ocorre a traduçăo de mRNAs pré-formados e armazenados nos zoósporos (Soll e Sonneborn,. 1971a; Leaver e Lovett, 1974; item III.1.2.5). Portanto, durante o choque térmico na germinaçăo, poderia estar ocorrendo apenas ativaçăo da tradução de mRNAs de choque térmico preexistentes nos zoósporos. Com o objetivo de determinar se a regulaçăo da resposta ao choque térmico seria diferente na esporulação e germinaçăo, células das duas fases foram submetidas ao tratamento térmico na presença de actinomicina D. 0 tratamento de zoósporos com actinomicina $D(5 \mu g / m L)$ durante a germinaçăo inibiu a induçăo de Hsps (năo mostrado), sugerindo que o controle da expressa destas proteinas ocorre principalmente ao nível da transcriçăo. A síntese de 
148.

Hsps foi também inibida pela adição de actinomicina D $(5 \mu \mathrm{g} / \mathrm{ml})$ durante o choque térmico em qualquer momento da esporul açăo.

Uma evidencia adicional de que os mRNAs das hsps acumulam durante o choque térmico foi obtida a partir de resultados de traduçá "in vitro" de RNAs obtidos de células normais e de células que sofreram tratamento térmico. A eletroforese unidimensional dos produtos da traduça "in vitro" de RNAs poli( $(A)$ - de células normais e aquecidas revelou um significativo aumento na síntese de algumas proteínas com migraçao eletroforética similar à Hsp70, Hsp30, Hsp25 e Hsp17 (năo mostrado). Portanto, o aumento na sintese destas proteínas que ocorre durante a choque térmico reflete o aumento da abundancia de seus respectivos mRNA5. A eletroforese bidimensional destes produtos de traduço "in vitro" confirmou que os mRNAs para as Hsp70, Hsp30a, Hsp25, Hsp17a e Hsp17b săo de fato induzidos durante - choque térmico (Fig.31A,日). Além disso, existe uma clara correspondencia, em termos de mobilidade eletroforética, entre a proteína de 70 kDa traduzida "in vitro" a partir de RNA poli(A)* de células de 120 min de esporulaça e a Hsp 70 traduzida a partir de RNA obtido de células que sofreram choque térmico (Fig.31L). Os zoósporos năo contém mRNAs de choque térmico (Fig.31D), confirmando os experimentos feitos com actinomicina $D$, os quais mostraram que, mesmo durante a germinaçăo, a regulaçăo da expressăo dos genes de choque térmico ocorre provavelmente a nivel da transcriça. 


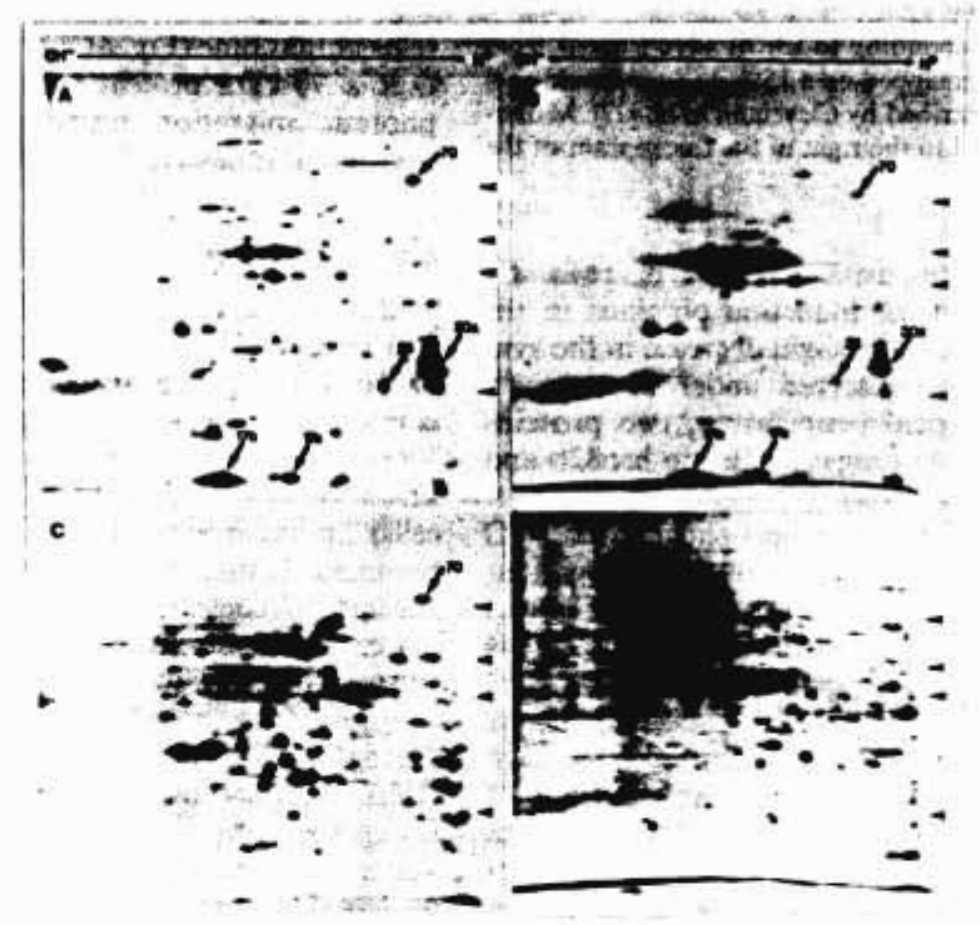

Figura 31 - Traduçăo "in vitro" de RNA isolado de células normais e de células submetidas a tratamento térmico. mRNAs poli $(A)^{+}$isolados de cada amostra foram traduzidos em lisado de reticulócitos e os polipeptídios resultantes foram analisados em eletroforese bidimensional IEF/SDS. (A) Células esporulantes aquecidas a $38^{\circ} \mathrm{C}$ no intervalo 30-60 min ou (B) 90-120 min após induç go da esporulaçă; (C) células esporulantes após $120 \mathrm{~min}$ de esporulaça a temperatura normal; (D) zoósporos. As setas apontam as proteínas de choque térmico. 


\subsection{Confirmaça da identidade entre a proteína de} 70 kDa induzida espontaneamente na esporulaça e a Hsp70

Com o objetivo de confirmar a identidade entre a proteína de $70 \mathrm{kDa}$, sintetizada espontaneamente durante esporulação, e a Hsp70, principal proteína de choque térmico de Elastocladiella, comparamos os fragmentos proteoliticos resultantes da digestao parcial destas proteínas com protease 48 de Staphylococcus aureus. A banda em gel bidimensional correspondente a Hsp70 induzida pelo choque térmico e a banda correspondente à proteína de 70 kDa induzida aos 120 min da esporulaçăo foram cortadas do gel e submetidas à proteólise Limitada como descrito por Cleveland et al. (1977). Como mostrado na Fig.32, o padrao dos peptídios obtidos da digestao da Hsp70 e da proteina de 70 kDa é idêntico.

Para determinar se o mRNA da Hsp70 era expresso durante a esporula̧̧o, em temperatura normal, fizemos hibridizaçŏes de "blots" de RNA, utilizando como sonda o gene hsp70 de Drosophila clonado em pBR322. Assim, em condições de baixa estringência, detectamos um transcrito de 2600 nucleotideos nos "blots" tanto de RNA total (Fig.33B) como de RNA poli(A+) (Fig.33A). Durante a esporulaça à temperatura normal, observa-se máxima quantidade deste transcrito aos $120 \mathrm{~min}$ (Fig.33P); nenhuma hibridizaçă foi detectada com RNAs de células do início da esporulaça (Fig. 3 gh) ou mesmo 


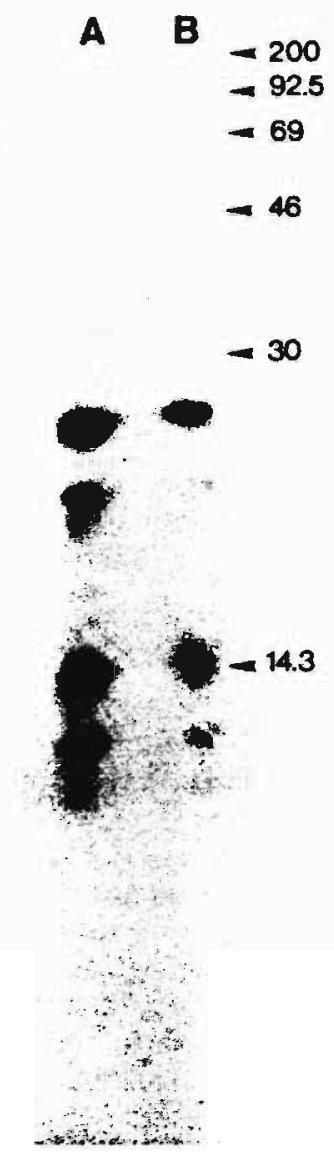

Figura 32 - Comparaça dos mapas peptidicos da proteina Hsp70, induzida pelo choque térmico durante a germinaçao, e da proteína correspondente de $70 \mathrm{kDa}$ induzida espontaneamente durante a esporulaçao. Células esporulantes foram marcadas com |3s5/metionina no intervalo 90-120 min da esporulaçăo à temperatura normal (A). Durante a germinaça as células foram aquecidas a $38^{\circ} \mathrm{C}$ no intervalo $15-45 \mathrm{~min} n a$ presença de lass/metionina (B). As bandas correspondentes a Hsp70 foram cortadas de gel bidimensional e submetidas à digestgo proteolitica parcial com protease vo de Staphylococcus aureus. Ds fragmentos obtidos foram separados através de eletroforese unidimensional em gel de poliacrilamida 15\%/5D5 e detectados por fluorografia. Ds marcadores de peso molecular em kDa esta indicados à direita do auto-radiograma do gel. 


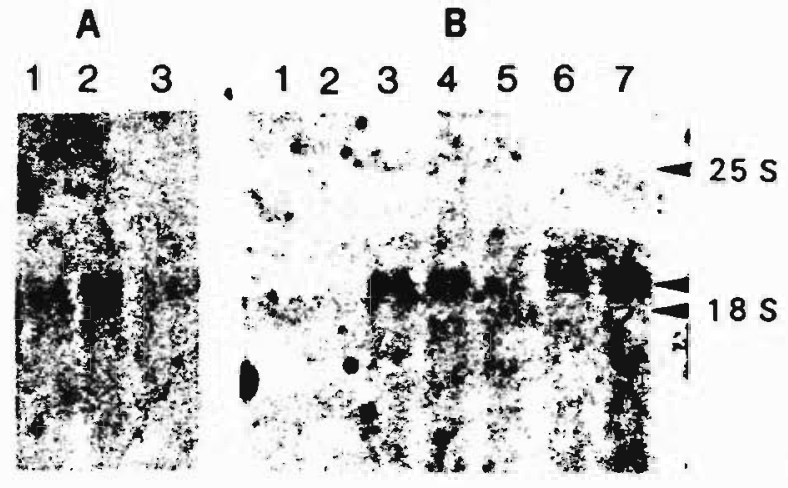

Figura 33 - Hibridização da sonda do gene hsp70 de Drosophila com RNA isolado de células controle e células aquecidas a $38^{\circ} \mathrm{C}$. Após separaça através de eletroforese em géis de agarose e transferência para filtros Gene Screen, o RNA foi submetido à hibridizaço com a sonda ( plasmídeo 88 contendo o gene hsp70 de Drosophila J marcada com $32 p$ pela reaçăo de "nick-translation". (A) RNA poli(A)+ isolado de células após 60 (1), 120 (2) e 180 (3) min após induçăo da esporulaça a $27^{\circ} \mathrm{C}$. (B) RNA total isolado de células esporulantes aquecidas a $38^{\circ} \mathrm{C}$ nos intervalos $30-60 \mathrm{~min}$ ( 3 ), 60-90 min (4), 90-120 min (5), 90-150 min (6) ou 150-180 min (7) e células controle após $30 \mathrm{~min}$ (1) ou $180 \mathrm{~min}$ (2) da induçăo da esporulaçăo. A menor intensidade de hibridizaça observada nas canaletas 5 e 6 é devido a menor quantidade de RNA aplicada. As setas apontam a posiça das rRNAs (255 e 185 vizualizadas pela coloraçăo do gel com brometo de etidiole do transcrito de 2600 nucleotídeos. 
de zodsporos (nao mostrado). Estes dados concordam comos resultados sobre a síntese "in vivo" da protelina de $70 \mathrm{kDa}$ verificada durante a esporulaçao normal, bem como com os resultados de traduça "in vitro", que demonstraram a comigraçăom eletroforese bidimensional desta proteina de $70 \mathrm{kDa}$ com a Hsp70 (Figs.30 e 31). Além disso, a Fig.33B mostra que a sintese da Hsp70, induzida pelo choque térmico nos vários momentas da esporulaça, é também devida a um acúmulo do mRNA para Hsp70.

Mais uma evidência da identidade entre a proteína de 70 kDa e Hsp 70 de Blastocladiella foi obtida ao detectarmos reaça imunológica cruzada de ambas proteínas com o antisoro contra a proteína DnaK de E.coli, análoga à Hsp70 em procariotos (Bardwell e Craig, 1984). Como mostra a Fig.34, uma banda dupla na regia de $70 \mathrm{kDa}$ do gel foi precipitada especificamente, de extratos de células de Blastocladiella marcadas com lass/metionina, pela anticarpo anti-Dnak. A quantificaçăo, através de ensaio de imunoprecipitaçăo, do aumento da sintese da proteina de 70 kDa durante a esporulaçăo năo pôde ser feita devido à proteólise que ocasionalmente ocorre durante a incubaça com o anticorpo.

Também detectamos reaçăo imunológica da proteína Hsp70 de Blastocladiella com anticorpo monoclonal contra Hsp70 de Drosophila. Este anticorpo reconhece um epitopo conservado nos vários membros da familia dos genes hsp70 na maioria das células eucarióticas (Kurtz et al.,1986). Nas figuras 35A e 35B, săo mostrados "immunoblots" de géis bidimensionais de 
154.

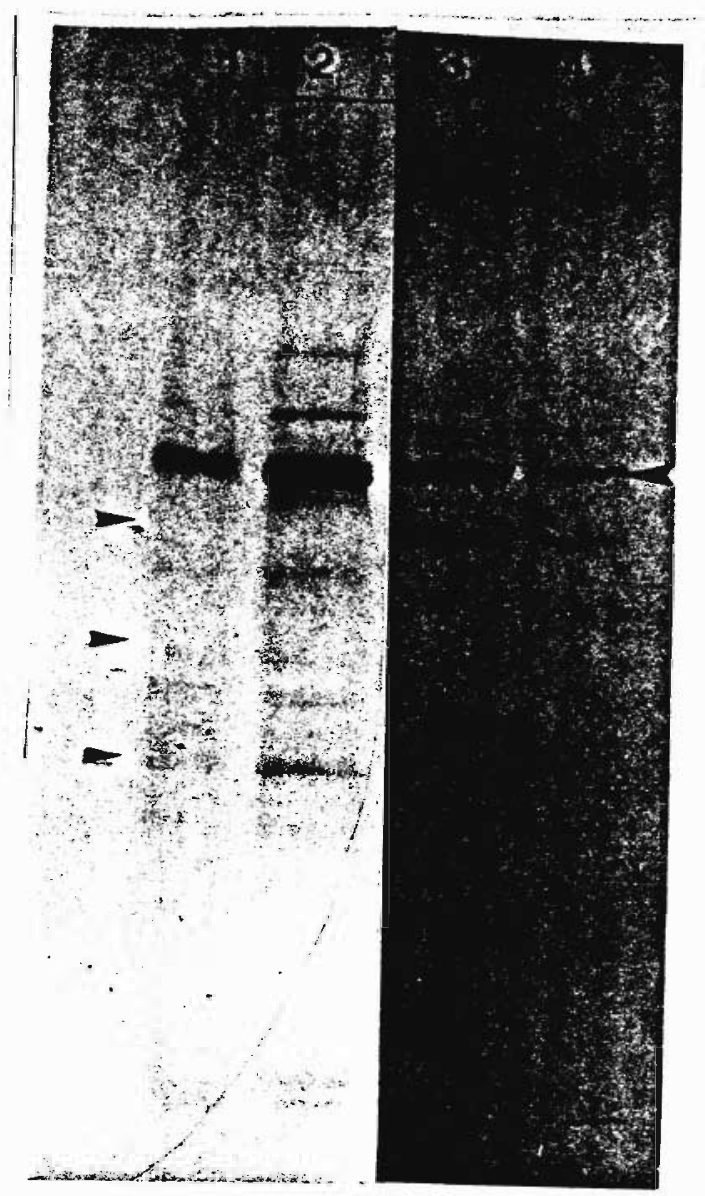

Figura 34 - Imunoprecipitação da proteína de 70 kDa de células normais e aquecidas a $38^{\circ} \mathrm{C}$. Extratos de células marcadas com |3s 5 |metionina foram submetidas à imunoreaça com anti-soro contra a proteína Dnak de E.coli. As proteínas precipitadas foram analisadas através de eletroforese unidimensional e fluorografia. Canaletas: (1), células esporulantes de $120 \mathrm{~min}$; (2), células esporulantes aquecidas no intervalo 30-60 min de esporulaço; ( 3 ), células de E.coli cepa $K 12$ aquecidas a $42^{\circ} \mathrm{C}$ por $12 \mathrm{~min}$; (4), células de E.coli mantidas a temperatura normal. Em Blastocladiella, a marcaşa com lass/metionina foi feita nos 20 min finais da incubaçăo e em E.coli nos 7 min finais. A seta à direita aponta a Hsp70. As setas a esquerda representam os marcadores de peso molecular $(67,55,45 \mathrm{kDa}$, de cima para baixo). 


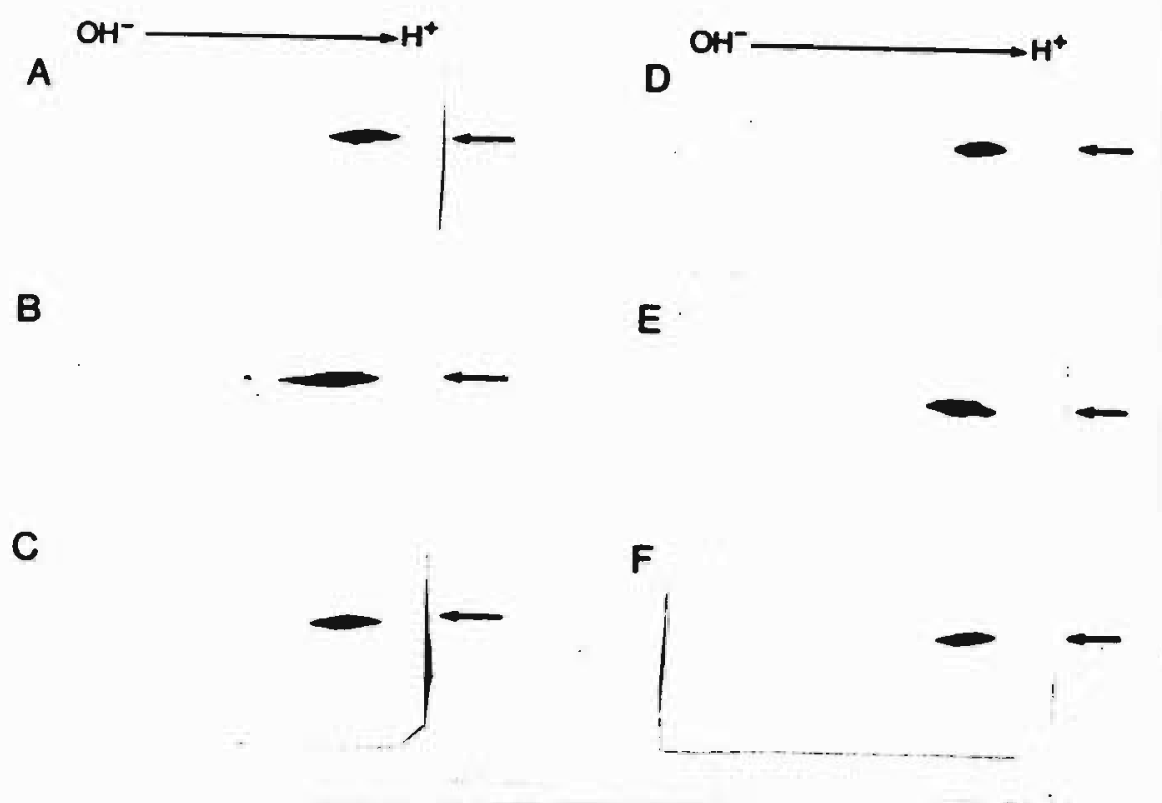

Figura 35 - Imunodeteçร̆o da Hsp70 em "blots" de géis bidimensionais. Proteínas totais de celulas de $120 \mathrm{~min}$ de esporulaçăo ( $A$ ), células aquecidas a $38^{\circ} \mathrm{C}$ entre $0-60 \mathrm{~min}$ de esporulaçro (B), germes de $45 \mathrm{~min}$ em meio $A L$ (D) e germes aquecidos a $38^{\circ} \mathrm{C}$ entre $15-45 \mathrm{~min}$ de germinagro (E) foram submetidas à eletroforese bidimensional IEF/SDS e transferéncia. (C) e (F) correspondem a mistura das amostras analisadas em ( $A$ e $B$ ) ( $e$ e E), respectivamente. Os "blots" foram incubados com anticorpo monoclonal anti-Hsp70 de Drosophila, desenvolvido em rato, lavados e incubados com anticorpo anti-IgG de rato desenvolvido em coelho. 0 complexo antígeno-anticorpo foi revelado imunoenzimaticamente através de reaça de diaminobenzidina e $\mathrm{H}_{2} \mathrm{O}_{2}$ con peroxidase conjugada a anti-IgG de coelho. Estro apresentados apenas parte de cada "blot". As setas a direita apontam a proteína Hsp70. 
proteinas isoladas de células esporulantes de $120 \mathrm{~min}$ e de células esporulantes aquecidas a $38^{\circ} \mathrm{C}$, no intervalo $0-60 \mathrm{~min}$ da esporulaçăo. O "immunoblot" do gel em que ambas as amostras foram misturadas na revelou nenhuma banda adicional, demonstrando se tratar da mesma proteína (Fig.35[). Este monoclonal anti-Hsp70 também detectou a mesma proteína de 70 kDa nos "immunoblots" de géis bidimensionais das proteinas isoladas de germes de $45 \mathrm{~min}$ submetidos ou năo a tratamento térmico de $30 \mathrm{~min}$ $(F i g 5.35 D, E, F)$.

\subsection{Indução de termotolerância durante o desenvolvi-} mento de $B$. emersoni

A termotolerância é definida como a capacidade das células sobreviverem a uma temperatura letal se forem previamente expostas a temperaturas supra-ótimas ou outros tipos de estresses. Embora exista alguma controversia, tem sido proposto um envolvimento das proteinas de choque térmico e a aquisigga de termotolerância. Contudo, alguns dados indicam que não necessariamente todas as Hsps estăo envolvidas nesta proteçăo (para revisaro, ver Lindquist, 1986; [raig, 1985).

Ho estudarmos a resposta ao choque térmico durante o ciclo de vida de B.emersonii verificamos que diferentes conjuntos de Hsps for am induzidos em cada fase cesporulaçro, germinaçăo e crescimento), demonstrando que, neste 
organismo, a expressão dos genes de choque térmico ngo é coordenada. Além disso, durante a esporulaçăo algumas Hsps são espontaneamente expressas. Com o objetivo de determinarmos quais proteínas de choque térmico estro envolvidas na aquisiça do efeito protetor conferido pela termotolerância, investigamos a síntese de proteínas durante a aquisiçăo da termotolerância em Blastocladiella.

As células de diferentes fases do ciclo de vida (inicio da esporulaçăo, germinaçăo inicio do crescimentol foram submetidas a diferentes condiçoses de hipertermia. As células foram expostas diretamente a $42^{\circ}[$ ou submetidas a um prétratamento a $34^{\circ} \mathrm{C}$, seguido de um tratamento a $38^{\circ} \mathrm{C}$ e finalmente expostas a $42^{\circ} \mathrm{C}$. D efeito destes tratamentos na sobrevivência das células está mostrado na Fig. 36 . A sobrevivência foi determinada pela capacidade de produça de zoósporos após retorno a $27^{\circ} \mathrm{C}$ das células tratadas, para que pudessem assim retomar o seu desenvolvimento normal. Durante a germinaçăo, a pré-incubaçăo a temperaturas intermediárias $\left(34^{\circ} \mathrm{C}\right.$ por $15 \mathrm{~min}$ e $38^{\circ} \mathrm{C}$ por mais $15 \mathrm{~min}$ ) protege contra os efeitos letais da hipertermia a $42^{\circ} \mathrm{C}$ (Fig.36B). Durante a esporulaçăo e crescimento também ocorre uma proteçăo, embora não tăo acentuada (Figs.36A, [). A viabilidade năo é afetada quando as células são aquecidas diretamente a $38^{\circ} \mathrm{C}$.

Se a sintese de Hsps for bloqueada com cicloeximida durante a incubaçăo a $34^{\circ} \mathrm{C}$ e $38^{\circ} \mathrm{C}$, as células năo 5 ăo protegidas da morte a $42^{\circ} \mathrm{C}$ (nao mostrado). 
158.
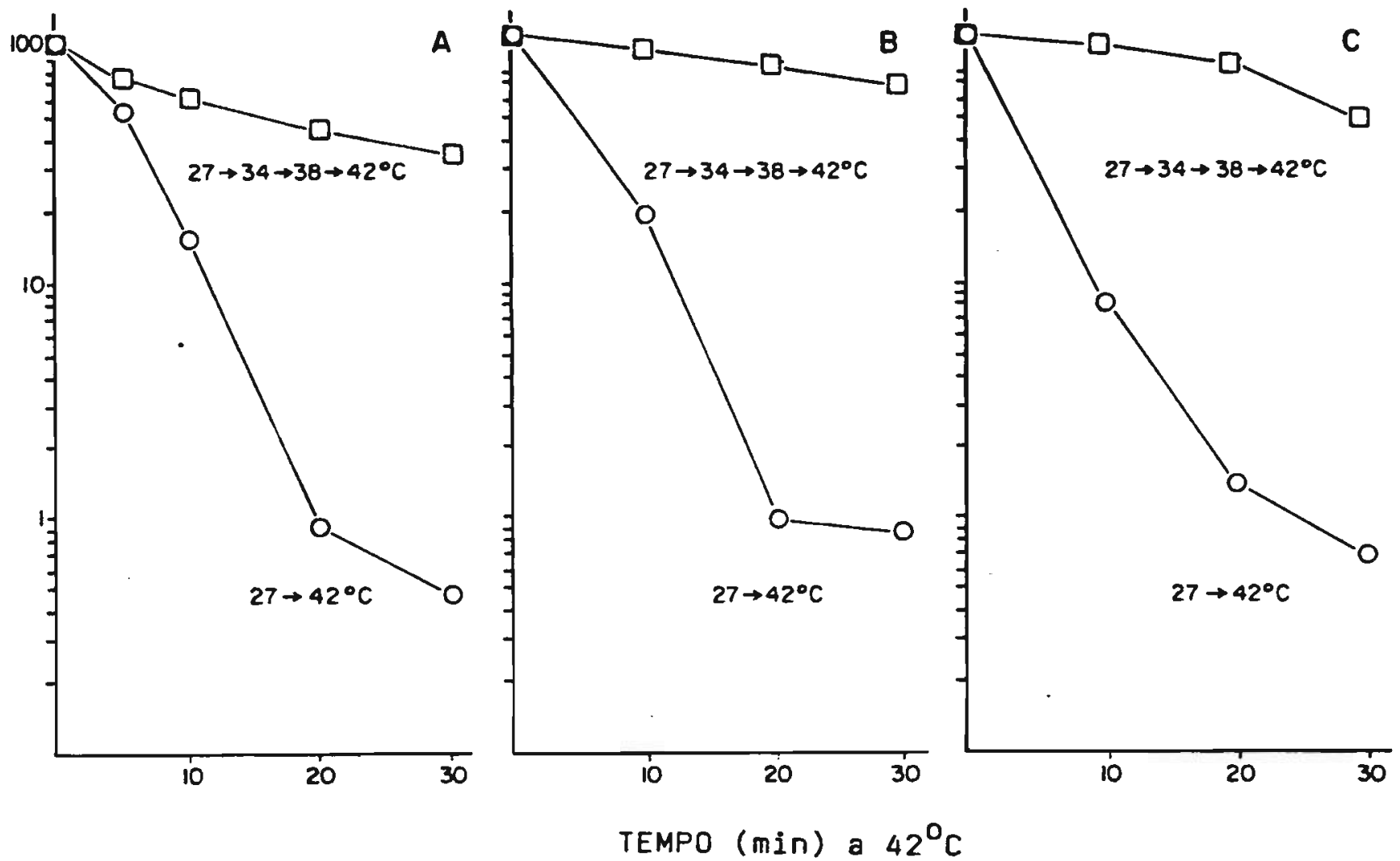

Figura 36 - Induço de termoproteço. (P) Células esporulantes foram sucessivamente transferidas para $34^{\circ} \mathrm{C}$ por $30 \mathrm{~min}$, para $38^{\circ} \mathrm{C}$ por $30 \mathrm{~min}$ e finalmente incubadas a $42^{\circ} \mathrm{C}$ ( $\square \square$ ) ou transferidas diretamente para $42^{\circ}[(O-O)$ ). (B) Zobsporos induzidos a germinar em meio $A L$ a $27^{\circ}[$ durante 15 min foram transferidos diretamente para $42^{\circ} \mathrm{C}(\mathrm{O}-\mathrm{O}$ ) ou sucessivamente para $34^{\circ} \mathrm{C}$ por $15 \mathrm{~min}$, para $38^{\circ} \mathrm{C}$ por $15 \mathrm{~min} e$ entro para $42^{\circ}\left[\left(\square-{ }^{\circ}\right.\right.$ ). (C) Celulas en crescimento a $27^{\circ} \mathrm{C}$ foram transferidas diretamente para $42^{\circ}[(0)$ sucessivamente transferidas para $34^{\circ} \mathrm{C}$ por $30^{\circ} \mathrm{min}$, para $38^{\circ} \mathrm{C}$ por 30 min e finalmente para $42^{\circ} \mathrm{C}$ ( $\left.\square-\square\right)$. Após os tempos indicados de incubaço a $42^{\circ} C$, as células foram retornadas para $27^{\circ} \mathrm{C}$ a viabilidade foi aferida. $100 \%$ corresponde a viabilidade das células mantidas a $27^{\circ} \mathrm{C}$ que nyo sofreram qualquer tratamento. 
Ho analisarmos o padrăo unidimensional das proteínas sintetizadas por células em crescimento expostas a diferentes temperaturas (Fig.37) observamos uma alta incorporaçăo de las5/metionina nas células aquecidas até $38^{\circ} \mathrm{C}$ sendo que acima desta temperatura $\left(40^{\circ} \mathrm{C}\right)$ ocorre uma drástica queda na incorporaçăo. A $42^{\circ} \mathrm{C}$, a síntese proteica diminui mais que $95 \%$. Na incubaçăa a $38^{\circ} \mathrm{C}$ por $30 \mathrm{~min}$, foram induzidas proteínas de choque térmico. Estas proteínas foram também sintetizadas quando as células em crescimento foram inicialmente expostas a $34^{\circ} \mathrm{C}$, transferidas para $38^{\circ} \mathrm{C}$ e finalmente expostas a $42^{\circ} \mathrm{C}$.

Através de eletroforese bidimensional fizemos uma análise mais detalhada das proteinas sintetizadas durante a termotolerancia nas diferentes fases do ciclo. Na Fig.38, os auto-radiogramas das proteinas sintetizadas na termotolerância săo comparados aos padrós obtidos à temperatura normal e durante o choque térmico a $38^{\circ} \mathrm{C}$. $\mathrm{A}$ tabela 2 resume estes resultados. Como apresentado no item III.2.1, a exposição das células a $38^{\circ} \mathrm{C}$ induz a síntese de conjuntos especificos de Hsps dependendo do estágio de desenvolvimento das células. Durante a termotolerancia, em cada uma das três fases analisadas, foram induzidas a maioria, se nåo todas, das Hsps típicas da esporulaçăo ou da germinação ou do crescimento, sendo que algumas Hsps săo comuns a estas três fases. Assim, pode ser feita uma correlacão entre a induçăo da síntese das Hsps 82a, 82b, 76, $70,60,25$ e $17 b$ e o desenvolvimento da termotolerancia. E 
160.

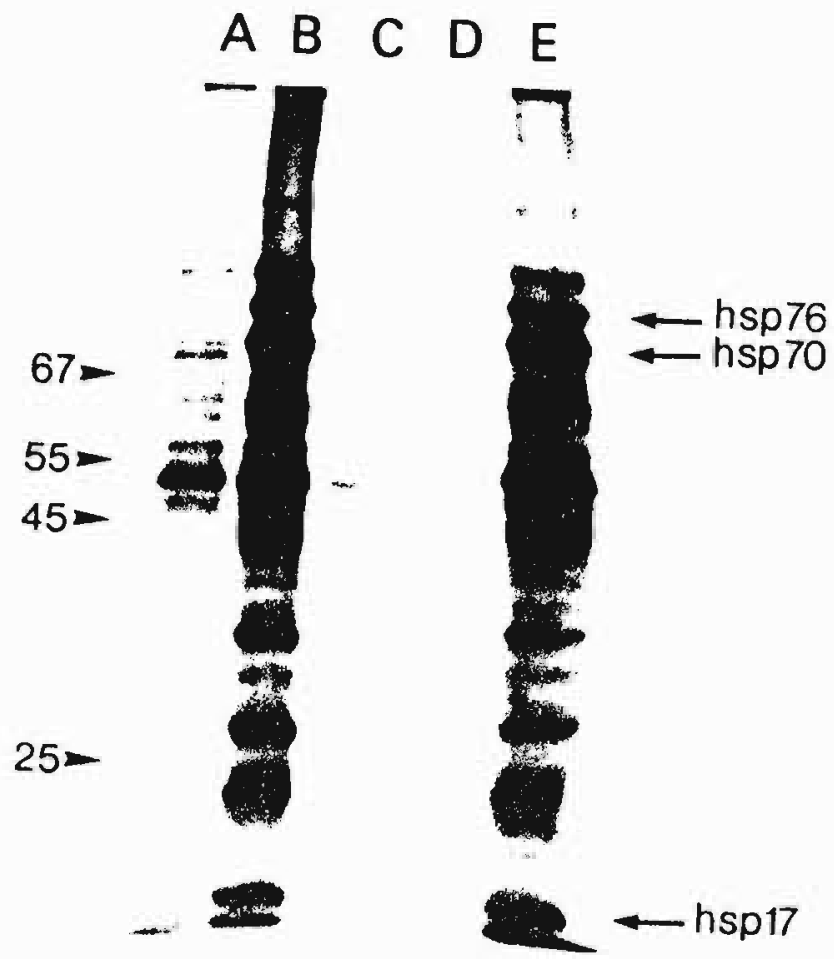

Figura 37 - Padra unidimensional de proteínas sintetizadas a diferentes temperaturas e durante a termotolerancia. Células no início do crescimento em meio $A L$ foram tratadas por $30 \mathrm{~min} a 27^{\circ} \mathrm{C}$ (A), $38^{\circ} \mathrm{C}$ (B), $40^{\circ} \mathrm{C}$ (C), $42^{\circ} \mathrm{C}$ (D) ou tratadas por $30 \mathrm{~min} a 34^{\circ} \mathrm{C}, \mathrm{C}$ transferidas para $38^{\circ} \mathrm{C}$ por 30 min e entaro aquecidas a $42^{\circ} \mathrm{C}$ por $30 \mathrm{~min}$ (E). Quantidades equivalentes de proteinas foram aplicadas em cada canaleta. A marcaçăo com las 5 /metionina foi feita nos $20 \mathrm{~min}$ finais de cada incubaçăo ou durante todo o período de induçăo de termotolerancia. As setas à esquerda representam os marcadores de peso molecular $(67,55,45$ e $25 \mathrm{kDa}$, de cima para bai $\times 0$ ). 


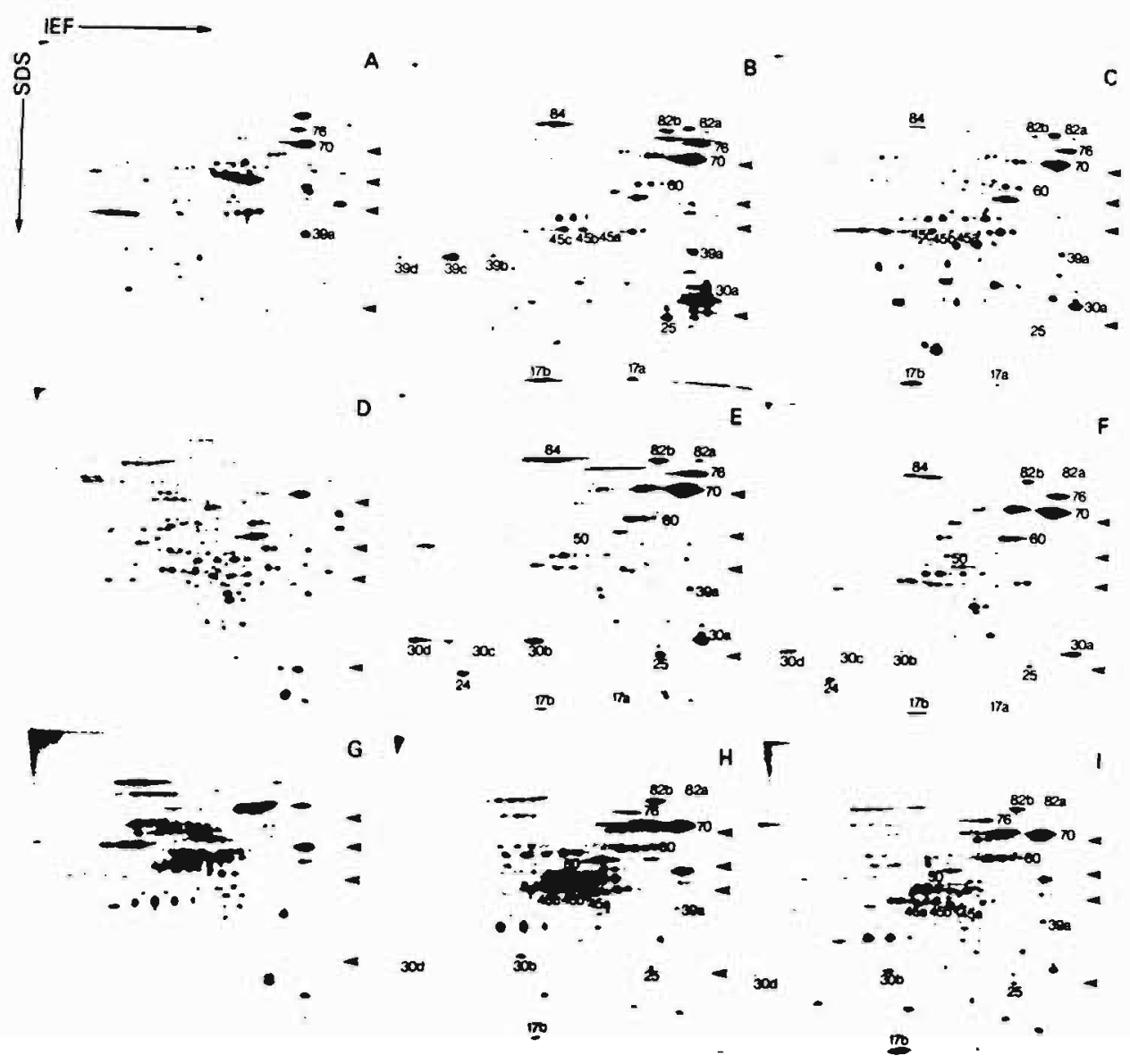

Figura 38 - Padrao bidimensional (IEF/SDS) de proteínas sintetizadas durante a termotolerancia induzida na esporulaçăo, germinaçăo ou crescimento. Hs células foram induzidas a esporular e em seguida foram mantidas a $27^{\circ} \mathrm{C}$ por $90 \mathrm{~min}(A)$, ou aquecidas a $38^{\circ} \mathrm{C}$ no intervalo 60-90 min (B), ou transferidas sucessivamente para $34^{\circ}\left[\right.$, $38^{\circ} \mathrm{C}$ e $42^{\circ} \mathrm{C}$ durante os intervalos 0-30 min, 30-60 min e 60-90 min respectivamente ( $[$ ), após a induça da esporulaçao. Zoósporos foram induzidos a germinar em soluçă inorgânica e mantidos a $27^{\circ} \mathrm{C}$ por $60 \mathrm{~min}(\mathrm{D})$, ou aquecidos a $38^{\circ} \mathrm{C}$ durante - intervalo 45-60 min (E), ou transferidos sucessivamente para $34^{\circ} \mathrm{C}, 38^{\circ} \mathrm{C}$ e $42^{\circ} \mathrm{C}$ durante os intervalos 15-30 $\mathrm{min}, 30$ $45 \mathrm{~min}, 45-60 \mathrm{~min}$, respectivamente (F), após induçăo da germinaçăo. Células no início do crescimento (120 mín após inoculaçăo dos zoósporos em meio $A L)$ foram mantidas a $27^{\circ} \mathrm{C}$ por $30 \mathrm{~min}(\mathrm{G})$, ou aquecidas por $30 \mathrm{~min}$ a $38^{\circ} \mathrm{C}(\mathrm{H})$, ou transferidas sucessivamente para $34^{\circ} \mathrm{C}, 38^{\circ} \mathrm{C}$ e $42^{\circ} \mathrm{C}$ por 30 min em cada temperatura (I). A marcaça com l3ss/metionina foi feita nos $20 \mathrm{~min}(10 \mathrm{~min} n a$ germinaço) finais da incubaça nas temperaturas indicadas ou durante todo o período de acquisiçăo de termotolerância. As setas à esquerda representam os marcadores de peso molecular (67, 55,45 e $25 \mathrm{kDa}$, de cima para baixol. 
TABELA 2. PROTEINAS DE CHOOUE TERMICD INDUZIDAS DURANTE A TERMOTOLERANCIA (TT) EM DIFERENTES ESTAGIOS DO CICLD DE VIDA DE B. emersoni

\begin{tabular}{|c|c|c|c|c|c|c|}
\hline \multirow{2}{*}{$\begin{array}{l}\text { hsps } \\
\text { (kDa) }\end{array}$} & \multicolumn{2}{|c|}{ esporulação } & \multicolumn{2}{|c|}{$\begin{array}{c}\text { germinação } \\
\text { tardia }\end{array}$} & \multicolumn{2}{|c|}{$\begin{array}{l}\text { inicio do } \\
\text { cresciment }\end{array}$} \\
\hline & $38^{\circ} \mathrm{C}$ & $T T$ & $38^{\circ} \mathrm{C}$ & TT & $38^{\circ} \mathrm{C}$ & $\mathrm{TT}$ \\
\hline 84 & + & + & + & + & - & - \\
\hline $82 a$ & + & + & + & + & + & + \\
\hline $8.2 b$ & + & + & + & + & + & + \\
\hline $76^{*}$ & + & + & + & + & + & + \\
\hline $70^{*}$ & + & + & + & + & + & + \\
\hline 60 & + & + & + & + & + & + \\
\hline 50 & - & - & + & + & + & + \\
\hline $45 a$ & + & + & - & - & + & + \\
\hline $45 b$ & + & + & - & - & + & + \\
\hline $45 c$ & + & + & - & - & + & + \\
\hline $39 a^{*}$ & + & + & + & - & + & + \\
\hline 390 & + & - & - & - & - & - \\
\hline $39 c$ & + & - & - & - & - & - \\
\hline 390 & + & - & - & - & - & - \\
\hline $30 a$ & + & + & + & + & - & - \\
\hline $30 \mathrm{~b}$ & - & - & + & + & + & + \\
\hline $30 \mathrm{c}$ & - & - & + & + & - & - \\
\hline $30 d$ & - & - & + & + & + & + \\
\hline 25 & + & + & + & + & + & + \\
\hline 24 & - & - & + & + & - & - \\
\hline $17 a$ & + & + & + & + & - & - \\
\hline $17 b$ & + & + & + & + & + & + \\
\hline
\end{tabular}

* estas proteínas 5 a o sintetizadas espontaneamente durante a esporulaço 
provácel que as outras Hsps $(84,50,45 a, 45 b, 45 c, 39 a$, 39b, 39c, 39d, 30a, 30b, 30c, 30d, 24 e $17 a$ ) nao estejam especificamente envolvidas na termotolerancia.

\subsection{Discuss\%o}

A sintese de pelo menos 22 polipeptídios é acentuadamente induzida quando células de Blastacladiella sao submetidas ao choque térmico a $38^{\circ} \mathrm{C}$ nas várias fases do seu ciclo de vida. A proteína de choque térmico mais abundante induzida em Blastocladiella, Hsp 70, é análoga à Hsp70 de Drosophila e à proteina Dnak de E.coli. A imunoprecipitaçăo de uma proteína de $70 \mathrm{kDa}$, induzida pelo calor, com o anti-soro anti-Dnak, a imunodeteçăo de uma proteina de $70 \mathrm{kDa}$ com anticorpo anti-Hsp70 de Drosophila, além da deteç̧ăo do seu mRNA, utilizando-se o gene hsp70 de Drosophila como sonda, forneceram fortes evidências acerca da identidade destas proteínas, confirmando a extrema conservagá da Hsp70 na evoluça. As Hsps de Blastocladiella possuem um padrăo de induçao característico de cada fase do desenvolvimento. Algumas Hsps năo 5 ăo induzidas em certas fases mesmo sob tratamento térmico, enquanto a sintese de outras é induzida pelo choque térmico apenas em fases especificas do ciclo de vida. Por exemplo, as Hsps 24 e $30 \mathrm{C}$ săo típicas da germinaçăo e nå săo expressas em qualquer outra fase do desenvolvimento, enquanto as Hsps 39b, 39c, 39d săo apenas expressas durante a esporulaçăo. Contudo năo 
164.

está claro porque uma classe particular de Hsps é preferencialmente induzida nos diferentes estágios do desenvolvimento; esta seletividade pode estar refletindo um fenômeno regulatório mais amplo e também fundamental para a diferenciaçăo do organismo. D comportamento destas Hsps contrasta com aquele de sete outras Hsps CHsp82a, Hsp82b, Hsp76, Hsp70, Hsp60, Hsp25, Hsp17b) que săo induzidas tanto durante o choque térmico na esporulaço como na germinaça e crescimento. Estas sete Hsps poderiam estar envolvidas com a aquisição de termotolerância que pode ser induzida neste fungo, como discutiremos a seguir.

A regulaçăo da sintese de Hsps em B.emersonii ocorre nåo apenas em resposta à elevaçăo da temperatura, mas também como parte do desenvolvimento normal deste organismo. Três proteínas de choque térmico (Hsp70, Hsp76, Hsp39a) săo sintetizadas durante fases especificas da esporulaça à temperatura normal, nao sendo sintetizadas espontaneamente em outras fases. Estudos de hibridizaçao de "blots" de RNA e traduçăo "in vitro" mostraram que o aumento da síntese da Hsp70 durante a esporulaçăo reflete a acumulaçăo do mRNA para esta proteina neste estágio especifico do desenvolvimento. Os resultados obtidos a partir de mapas peptídicos, sugerem fortemente a identidade entre o gene hsp70 que é expresso espontaneamente durante a esporulaça e aquele que é induzido pelo calor. E importante destacar que, de acordo com os dados obtidos da analise da síntese "in vivo" de proteinas, os níveis de sintese da Hsp70, Hsp76 e 
Hsp39a não săo significativamente aumentados se, durante a fase de induça espontanea, o organismo for submetido a hipertermia. A partir destes dados, podemos concluir que um controle do desenvolvimento está aparentemente superposto a indutibilidade da sintese de Hsps pelo calor.

Presumivelmente o aumento da síntese da Hsp70, e provavelmente de outras Hsps (76 e 39a), durante a esporulaça, năo é simplesmente uma resposta ao estresse causado pela carência nutritiva. 0 aparecimento da Hsp70 e Hsp76 ocorre somente após $120 \mathrm{~min}$ da induçao da carência, enquanto a variaço verificada no padra da síntese proteica tem inicio nos primeiros momentos da esporulaça (ítem III.1.1.; Silva et al., 1986). Portanto, a ativaçăo do gene hsp70 durante a esporulaça năo é parte da resposta à carência, mas parte de um programa de ativaça do desenvolvimento.

A proteína Hsp70 é uma das proteínas mais abundantes em Blastocladiella, conforme deteç̧o por coloraça com azul de Coomassie de géis bidimensionais de poliacrilamidalsDS (nao mostrados. Embora sua sintese seja forte e espontaneamente induzida entre 90-120 min da esporulaço e durante a choque térmico em qualquer fase do ciclo, seu conteúdo em massa parece nao variar durante o ciclo de vida e nem após a induçă do choque térmico, ao menos dentro dos limites de deteç̧a através da inspeçăo visual de géis corados. A Hsp70, sintetizada espontaneamente durante a esporulaçăo, é conservada nos zoósporos e germes, como pôde ser detectado 
166.

através da utilizaçăo do anticorpo monoclonal anti-Hsp70 de Drosophila. Durante a germinaça ngo observamos síntese da Hsp70; contudo durante o início do crescimento é sintetizada uma proteína de $70 \mathrm{kDa}$, com mobilidade eletroforética semelhante à Hsp70, que foi denominada proteína nG11 e cuja sintese é mantida em niveis basais ao longo do crescimento.

Uma familia de genes relacionados ao gene hsp70 foi encontrada nos genomas de Drosophila e leveduras (Ingolia et al., 1982; Ingolia e [raig, 1982b). Em ambos os casos, alguns membros 5 gुo induzidos pelo calor enquanto outros 5 ğo transcritos em condiçoses de crescimento normal e ngo să induzidos pelo tratamento térmico. Os produtos proteicos codificados por estes genes să similares, mas ngo identicos, quando analisados por eletroforese bidimensional ou mapeamento peptídico (Wadsworth, 1982; Craig e Jacobsen, 1985). A função destes genes cognatos permanece obscura.

A sintese proteica é essencial para o processo de germinação de zoósporos, sendo dirigida principalmente pelos mRNAs que estão armazenados nos zoósporos (ítem III.1.2.; Silva et al., 1987a). Em contraste, abtivemos evidências de que o controle da expressăo dos genes de choque térmico ocorre ao nível da transcriçăo, sendo que năo foi encontrado nenhum mensageiro para proteinas de choque térmico em zoósporos, apesar da indução de uma proteína identica à Hsp>0 durante a esporulaçăo.

Uma forte correlaçăo entre a expressa de Hsps e o desenvolvimento da termotolerancia tem sido encontrada em 
vários organismos (Mcalister e Finkelstein, 1980a; Loomis e Weeler, 1982; Li e Werb, 1982; Plesofsky-Vig e Brambl, 1985). A evidencia mais forte para a ligaço entre estes dois fenômenos foi encontrada em E.coli onde uma Linhagem com uma mutaçăo do gene regulatório (hin), que portanto ngo sintetiza Hsps, é incapaz de desenvolver termotolerancia (Yamomori e Yura, 1982). Em eucariotos esta evidência năo é tao clara. Alguns autores relataram que para a induçăo da termotolerância adquirida năo é necessária a sintese de Hisps (Hall, 1983; Widelitz et al., 1986). Em contraste, alguns trabalhos relatam o envolvimento direto de una certa classe de Hsps (Hsps de menor peso molecular) na proteça à hipertermia letal (Loomis e Weeler, 1982; Berger e Woodward, 1983; Nover e Scharf, 1984), embora recentemente tenha sido mostrado que a Hsp26 nåo é necessária para a acquisiçă da termotolerancia em Leveduras (Petko e Lindquist, 1986). Em células em cultura de fibroblastos de hamster chinês, o aumento da síntese da Hsp70 está correlacionado com o aumento da sobrevivencia ao calor ( $L i$, 1984). Em 5.cerevisiae, parece ser a proteína de choque térmico de 48 kDa a responsável pela termotolerância (Iida e Yahara, $1984 a, b)$.

Uma vez que durante a esporulaçăo algumas Hsps (Hsp76, Hsp70 e Hsp39a) săo constitutivamente expressas, seria esperado uma maior termorresistência para as células desta fase. Contudo, estas células săo aparentemente tao termossensiveis quanto células germinantes ou em 
168.

crescimento. Portanto, se estas Hsps exercem algum papel na termoproteção elas o desempentiam em consonância com outras Hsps. Portanto, é provável que a maioria das Hsps induzidas em Blastocladiella nao esteja especificamente envolvida na aquisiçăo da termotolerância. Nossos resultados demonstraram que apenas um grupo de sete Hsps (de um total de 22) parece estar envolvido no fenomêno de termoproteçăo. 


\section{Efeito do choque térmico na fosforilasgo da proteína ribossomal 56 de B. emersonii}

Dados obtidos anteriormente em nosso laboratorio demonstraram que o nível de fosforilaggo da proteina ribossomal 56 varia de intermediário a máximo durante o desenvolvimento e em resposta a alteraços do meio externo destas células (Bonato et al., 1984). Como em Blastocladiella a resposta ao choque térmico também esta sob - controle do desenvolvimento, com conjuntos especificos de Hsps sendo induzidos em cada fase do desenvolvimento (item III.2.1.; Bonato et al., 1987), este organismo poderia entgo ser utilizado para verificar se os diferentes niveis de fosforilaça de 56 estariam correlacionados com a traduça de mensagens específicas - tanto mRNAs de choque térmico ou normais - durante o choque térmico, recuperaçăo do choque térmico e indução da termotolerância nos diferentes estágios do ciclo de vida.

D nivel de fosforilaça de 56 em células expostas a hipertermia $\left(38^{\circ}[)\right.$ durante a esporulaça, germinaça e inf́cio do crescimento foi entáo examinado. 0 estado de fosforilaço de 56 pode ser medido de acordo com sua migraçăo eletroforética em géis bidimensionais de poliacrilamida e uréia corados com azul de Coomassie. Quanto mais fosforilada estiver a 56 menor é a sua migraçao em ambas as dimensões do gel (Lastick e Mcconkey, 1976; Gressner e Wool, 1974). 
Durante a esporulaçăa temperatura normal observa-se um grau intermediário para a fosforilaça de 56 (Fig.39A), em contraste aos derivados altamente fosforilados obtidos na primeira hora do crescimento em meio nutriente (Fig. $39[, E$ ). A forma naofosforilada de 56 é predominante durante a esporulaça a $27^{\circ} \mathrm{C}$, podendo ser visualizados os derivados 56a, 56b e 56c em quantidades decrescentes (Fig.39A). A germinaço pode ser induzida em meio nutriente ( $A L$ ) ou soluçăo inorgânica e, embora a cinética de germinaçăo seja idêntica em ambos os casos (cerca de $95 \%$ de germes após 4560 min), os níveis de fosforilaçăo de 56 săo significativamente diferentes (Fig.39[,G). Em soluçăo inorganica apenas os derivados 56 a e $56 b$ podem ser fracamente visualizados enquanto derivados altamente fosforilados são gradualmente induzidos após 60 e 90 min da induçăo da germinaçăo em meio de crescimento (Fig.39[,E). Quando todos esses tipos celulares 5 ão aquecidos a $38^{\circ} \mathrm{C}$ por 30 min, observa-se uma completa desfosforilaça de 56 (Figs.39B, D,F,H). Ds derivados fosforilados de 56 desaparecem completamente ocorrendo um aumento substancial da forma năofosforilada. D choque térmico năo apenas bloqueia a induçăo da fosforilaçăo de 56 (Figs.39[, D), como é responsável pela rápida desfosforilaça verificada quando células com máximo grau de fosforilaçăo de 56 (90 min de crescimento) săo aquecidas (Figs. 39E,F). Portanto, o choque térmico por $30 \mathrm{~min}$ a $38^{\circ} \mathrm{C}$ induz completa desfosforilaçăo de 


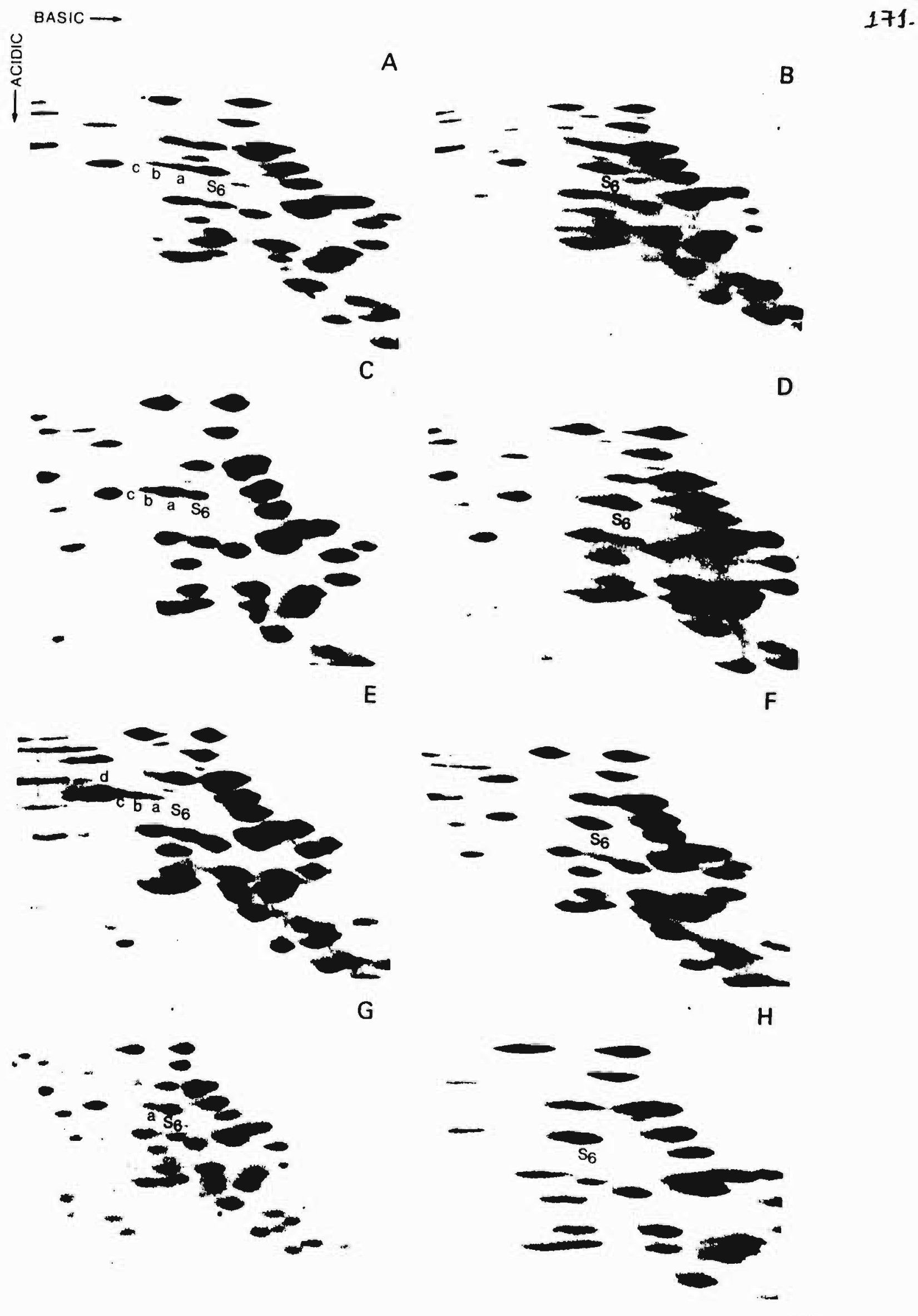

Figura 39 - Legenda na página seguinte 
Figura 39 - Desfosforilação da proteína ribossomal S6 durante o choque térmico na esporulaçăo, germinaçăo e início do crescimento. Ribossomos foram isolados e as proteínas ribossomais foram analisadas através de eletroforese bidimensional (básicolácido). Săo mostrados os géis corados com azul de Coomassie de (A) células esporulantes após 90 min de induçăo da esporulaçăo a $27^{\circ} C_{;}$(B) células esporulantes submetidas ao choque térmico no intervalo 60-90 min da esporulaçaro; (C) células germinantes obtidas apos 60 min da induça da germinaçăo de zósporos a $27^{\circ} \mathrm{C}$ em meio $\mathrm{AL}$; (D) células germinantes submetidas ao choque térmico durante - intervalo 30-60 min da germinaçજo em meio $R L ;$ (E) células após $120 \mathrm{~min}$ de crescimento a $27^{\circ} \mathrm{C}$ em meio $\mathrm{AL}$; (F) células em crescimento em meio $A L$ submetidas ao choque térmico durante o intervalo $90-120 \mathrm{~min}$; (G) células germinantes após 60 min de germinaçăo a $27^{\circ} \mathrm{C}$ em soluçăo inorgânica; (H) células germinantes em soluçăo inorgânica, submetidas ao choque térmico durante o intervalo 30-60 min. a, b, c e d indicam as diferentes formas fosforiladas de 56. 
56, independente do estado inicial de fosforilaça de 56 ser intermediário ou máximo.

Para investigar se a proteína 56 permanece desfosforilada quando as células sao induzidas a adquirir termotolerancia, comparamos o estado de fosforilaço de 56 de células expostas diretamente à temperatura letal ou expostas gradualmente a temperaturas supra-ótimas capazes de induzir termotolerância. O tratamento das células por $30 \mathrm{~min}$ a $42^{\circ} \mathrm{C}$ provoca morte celular, contudo a pré-exposiça a $34^{\circ} \mathrm{C}$ por 30 mine $38^{\circ} \mathrm{C}$ por mais 30 min confere às células uma resistência à incubaça letal de $30 \mathrm{~min}$ a $42^{\circ}[$, como apresentado no item III.2.3 (5ilva et al., 1987b). A figura 40 mostra que em células em crescimento submetidas a termotolerância, a 56 está também completamente desfosforilada. E interessante notar a desfosforilaggo incompleta de 56 nas células expostas diretamente a $42^{\circ} \mathrm{C}$, sugerindo que uma atividade de fosfatase parece ter sido parcialmente inibida nesta temperatura letal. Quando a termotolerancia foi induzida durante a esporulaço ou germinaçă, também foi observada a desfosforilaça de 56, enquanto a exposiça direta a $42^{\circ} \mathrm{C}$ também provocou uma incompleta desfosforilaçăo de 56 (resultados ngo mostrados), apesar dos niveis de fosforilaça característicos de cada uma destas fases.

Com objetivo de verificarmos se a recuperaça ao choque térmico estaria associada com a refosforilagro de 56, examinamos os padrós de síntese proteica e o estado de 
174.
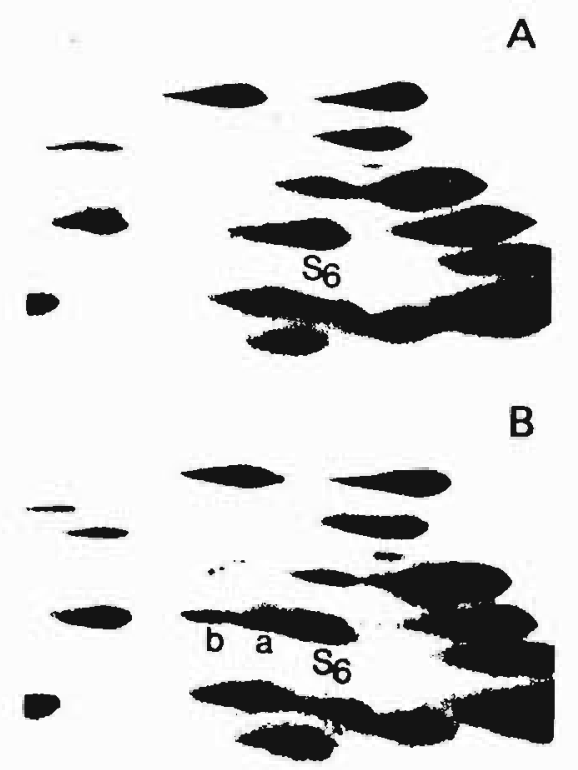

C

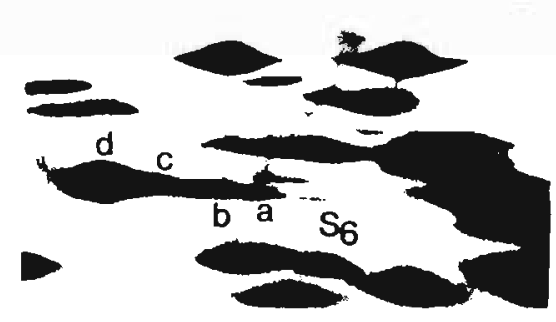

Figura 40 - Desfosforilaça de 56 durante a termotolerância. (A) Zósporos foram induzidos a germinar em meio $\mathrm{AL}$ por 30 min e em seguida transferidos para $34^{\circ} \mathrm{C}$ por $30 \mathrm{~min}$, para $38^{\circ} \mathrm{C}$ por $30 \mathrm{~min}$, e finalmente para $42^{\circ} \mathrm{C}$ por $30 \mathrm{~min}$. (B) Células após $90 \mathrm{~min}$ de crescimento em meio $\mathrm{AL}$ foram transferidas diretamente para $42^{\circ} \mathrm{C}$ por $30 \mathrm{~min}$. (C) Células após crescimento por $120 \mathrm{~min}$ a $27^{\circ} \mathrm{C}$. Sao mostradas regiós dos géis de proteínas ribossomais corados com azul de Coomassie. 
fosforilaçăo de 56 após vários tempos de retorno das células à temperatura normal, apos um choque térmico de $30 \mathrm{~min}$ de duraço durante a esporulacgo e inficio do crescimento. Esta análise nåo pode ser feita durante a germinaço porque, após 45 min da induçăo da germinaçăo em meio AL, os processos de germinaçăo e crescimento săo superpostos. Como apresentado no item III.2.1., durante o choque térmico a $38^{\circ} \mathrm{C}$ ngo ocorre uma completa inibiço da síntese proteica normal, mas existe uma clara induça de conjuntos especificos de proteínas de choque térmico, dependendo da fase do desenvolvimento. As Hsps 82a,82b, 76, 70, 60, 50, 45a, 45b, 45c, 39a, 30b, 30d, 25 e 17b sao induzidas durante o crescimento (Fig.41A) e as Hsps $84,82 a, 82 b, 76,70,60,45 a, 45 b, 45 c, 39 a, 39 b, 39 c$, 39d, $30 a, 25,17 a$ e 17b so induzidas durante o início da esporulaçăo (Fig.41D). Quando estas células retornam à temperatura normal $\left(27^{\circ}[)\right.$ a sintese de Hsps é gradualmente e diferencialmente inibida. Apos $60 \mathrm{~min}$ a $27^{\circ} \mathrm{C}$ a sintese das Hsps não é mais detectada em células em crescimento (Fig.41C). o mesmo ocorre após 90 min de recuperaça das células esporulantes (Fig.41E). Como mostrado na Fig.42, a cinética de refosforilaçăo de 56 coincide com a interrupça da sintese de Hsps e com a completa recuperaçăo do padrăo de síntese proteica normal, durante o inicio do crescimento e durante a esporulaçao.

A desfosforilaçă da proteina ribossomal s6 em resposta ao choque térmico demonstrou ser um fenomeno bastante especifico, não sendo simplesmente um evento geral de 


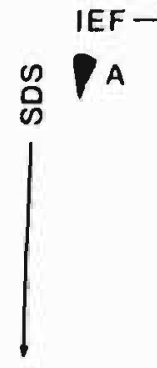

$\mathrm{EF} \longrightarrow$

176.

号 $P$

$\dot{\mathrm{D}}$
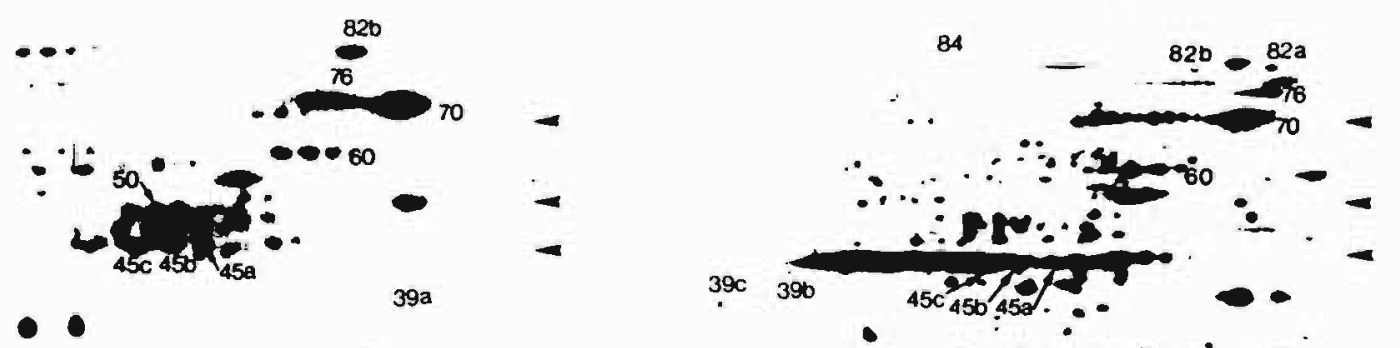

300

306

25

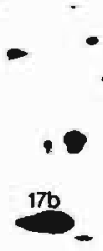

$-2_{25}^{2}$

176

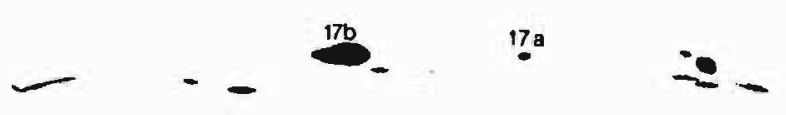

$r_{B}$

TE
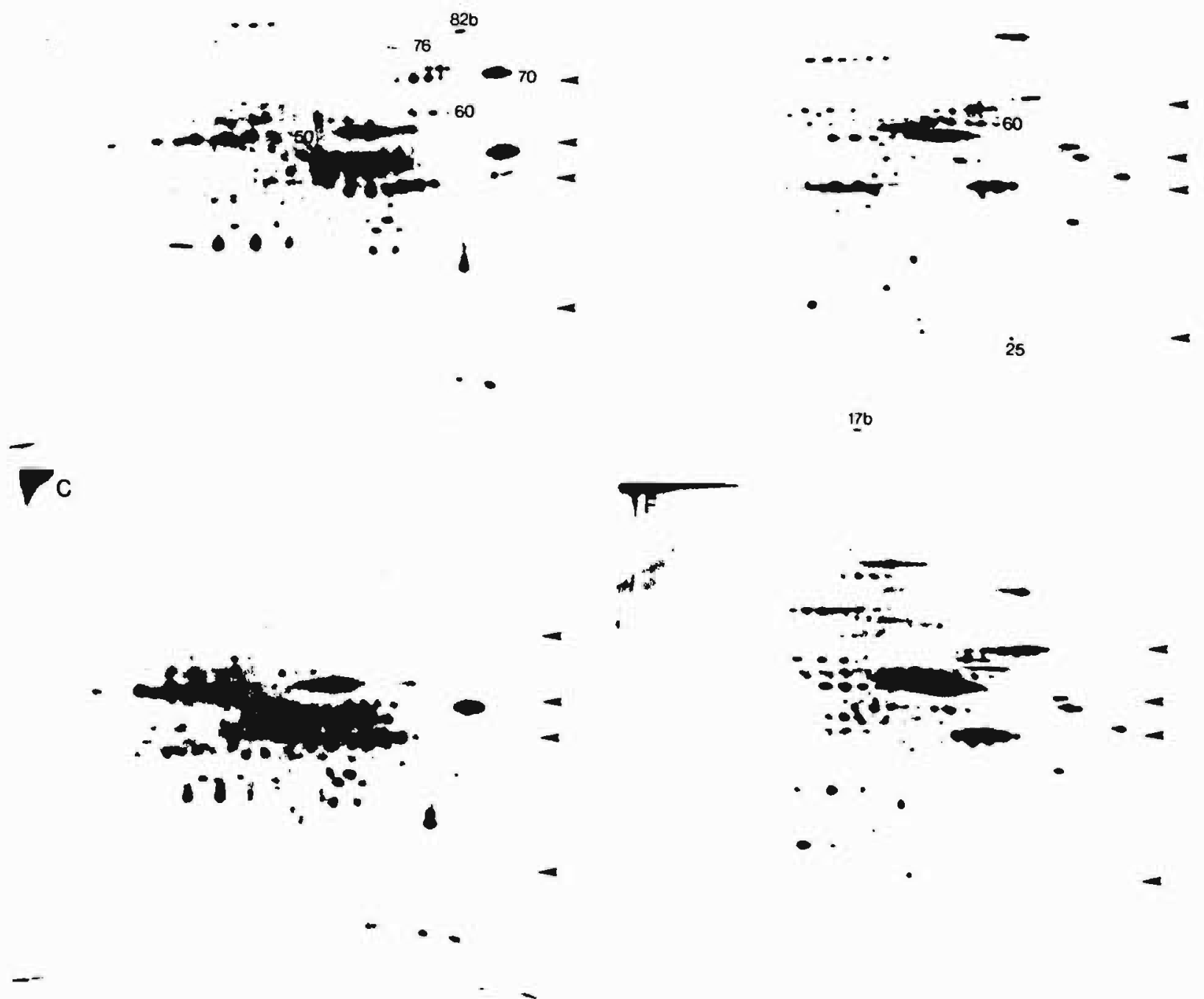

$17 \mathrm{~b}$

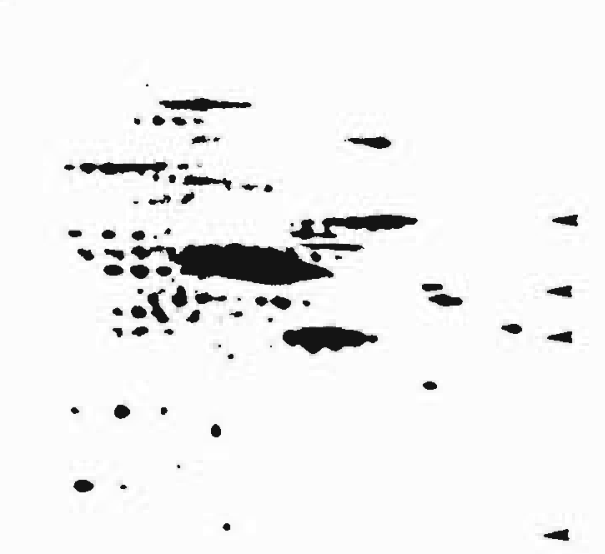

Figura 41 - Legenda na página seguinte 
177.

Figura 41 - Recuperaço da sintese de proteínas após tratamento térmico de $30 \mathrm{~min} e m$ células em crescimento e células esporulantes. Após $60 \mathrm{~min}$ de crescimento a $27^{\circ} \mathrm{C}$, as células foram submetidas a tratamento térmico a $38^{\circ}$ C (A) e retornadas para $27^{\circ} \mathrm{C}$ por $30 \mathrm{~min}$ (B) e $60 \mathrm{~min}$ (C). Após 30 min de induçăo da esporulaça a $27^{\circ} \mathrm{C}$, as células foram incubadas a $38^{\circ} \mathrm{C}$ por $30 \mathrm{~min}$ (D) e em seguida retornadas para $27^{\circ} \mathrm{C}$ por $60 \mathrm{~min}$ (E) e $90 \mathrm{~min}$ (F). Em todos os casos as células foram marcadas com jos/metionina nos 20 min finais da incubaça nos tempos indicados. As proteínas foram separadas através de eletroforese bidimensional IEF/SDS. As setas a direita dos auto-radiogramas (lado ácido) representam os marcadores de peso molecular $(67,55,45$ e 25 kDa, de cima para baixol. Os números indicam as Hsps. 
178.

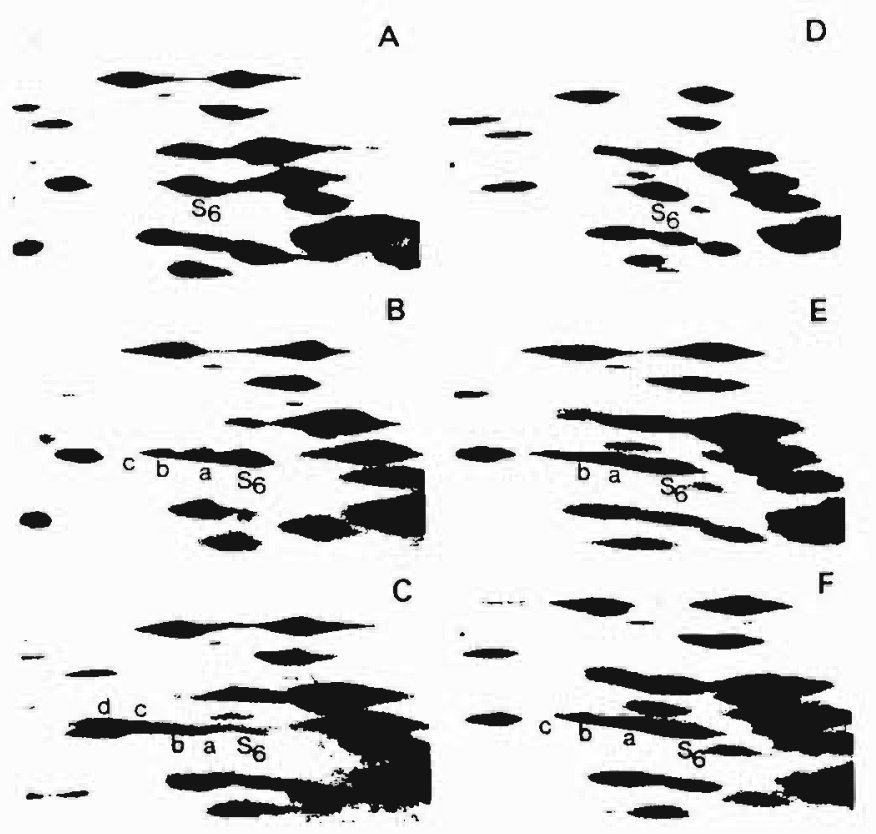

Figura 42 - Mudança no estado de fosforilação de S6 durante a recuperaça do choque térmico em células em crescimento e células esporulantes. A germinaçăo dos zoósporos foi induzida em meio de crescimento $\mathrm{AL} e$ as células foram submetidas a tratamento térmico no intervalo 60-90 min (A) e em seguida retornadas para $27^{\circ} \mathrm{C}$ por 30 (B) e $60 \mathrm{~min}$ (C). Células esporulantes foram aquecidas a $38^{\circ} \mathrm{C}$ durante o intervalo 30-60 min da esporulaça (D) e em seguida retornadas para $27^{\circ} \mathrm{C}$ por $60 \mathrm{~min}$ (E) ou $90 \mathrm{~min}$ (F). Sao mostradas regiós de géis de proteínas ribossomais corados com azul de Coomassie. 
179.

desfosforilaça de proteínas que estaria ocorrendo durante o choque térmico. Quando células marcadas com azp foram expostas a $38^{\circ} \mathrm{C}$ por $30 \mathrm{~min}$, padra de proteinas obtido através da eletroforese bidimensional em gel de poliacrilamida (IEF/SDS) é bastante similar àquele obtido com as células controle, exceto para três proteínas 680,72 e $48 \mathrm{kDa}$ cuja fosforilaça foi aumentada e outra ( $42 \mathrm{kDa}$ ) cuja fosforilaço sofreu um decréscimo (Fig.43).

\section{1. Discuss ăo}

Independente do estado inicial da fosforilaça de 56 (intermediário ou máximo), verificamos que o choque térmico provoca sempre uma completa e especifica desfosforilaço de 56. A desfosforilaçăo de 56 coincide com a resposta ao choque térmico, sendo que a 56 também permanece desfosforilada durante a termotolerancia. A recuperaça do choque térmico é acompanhada de um aumento na fosforilaçăo de 56, que termina por retornar aos niveis tipicos de cada estágio do desenvolvimento. Nossos resultados confirmam uma correlaçăo entre a desfosforil açăo de 56 e a traduçăo de uma classe definida de proteínas (Hsps), e mostram que a refosforilaçăo de 56 (mesmo a níveis intermediários) está associada com a retomada da síntese proteica normal e com a interrupçăo da síntese de proteínas de choque térmico, como previamente estabelecido para células Hela e células de tomate (Scharf e Nover, 1982; Kennedy et al., 1984). 
180.
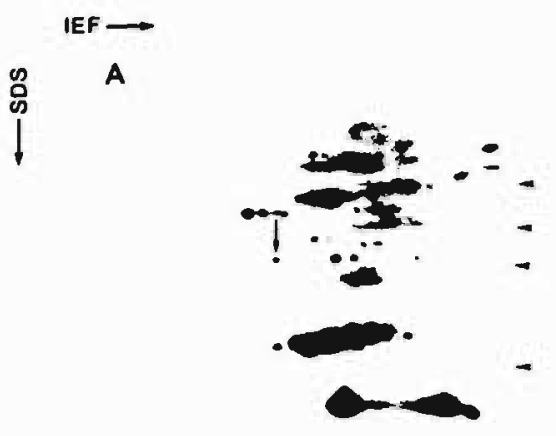

B

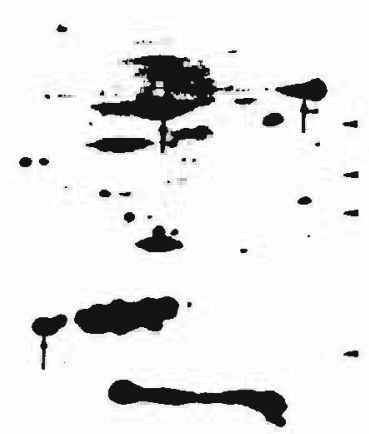

Figura 43 - Eletroforese bidimensional IEF/SDS de proteínas totais fosforiladas em células normais e aquecidas a $38^{\circ} \mathrm{C}$. Após $30 \mathrm{~min} d a$ induçăo de esporulaçao as células foram tranferidas para $38^{\circ} \mathrm{C}$ e mantidas nesta temperatura por 30 min (B). Em (A) células esporulantes de $60 \mathrm{~min}$, como controle. $A$ marcaça com $32 P$ foi feita durante todo crescimento e esporulaço. As setas a direita dos autoradiogramas ( lado ácido) representam os marcadores de peso molecular $(67,55,45$ e 25 kDa, de cima para baixo). 
Portanto, derivados de 56 altamente fosforilados parecen ngo ser necessarios à retomada da síntese proteica normal durante a recuperaçao do choque térmico.

Durante a germinaça dos zoósporos, a retomada da síntese proteica que ocorre em soluçăo inorgânica ou meio nutriente é também independente do grau de fosforilaggo de 56, uma vez que em soluço inorganica a 56 é quase que completamente desfosforilada enquanto que a germinaçro em meio nutriente - tanto na presença de extrato de levedura (meio DM3). (Bonato et al., 1984) ou de uma certa mistura de aminoácidos (meio AL) - Leva a um aumento da fosforilaça de 56 e os derivados d e c 5 go as formas predominantes. Contudo, nós observamos diferenças no padrăo de síntese proteica durante a germinação em meio AL e em soluço inorgânica (átem III. 1.2; Silva et al., 1987a). Todos estes resultados, se considerados juntos, indicam que a fosforilaçă de 56 poderia ter um papel na selecaro de mensagens especificas durante a tradução. Algumas mensagens requerem a 56 desfosforilada cpor exemplo mensagens para Hsps), outras mensagens (certas mensagens de crescimento) exigiriam máximos niveis de fosforilaçăo, e outras seriam traduzidas em qualquer condigăo (como por exemplo as mensagens normais cuja traduçăo năo é totalmente inter rompida durante a choque térmicos. No entanto esta é apenas uma mera especulaçă, já que năo temos nenhuma evidencia molecular do envolvimento da fosforilaçăo de 56 na seletividade da traduçăo. 
A fosforilaçăo de 56 nåo é o único candidato a ser responsabilizado pela tradução seletiva dos mRNAs de choque térmico. Variaçaes no estado de fosforilaçgo de fatores de iniciaçăo (eIF-2a e eIF-4B) como também fatores solúveis poderiam estar afetando a traduço das mensagens de choque térmico (Duncan e Hershey, 1984; De Benedetti e Baglioni, 1986; Sanders et al., 1986). Além disso os mRNAs de choque térmico possuem algumas caracteristicas na regiao 5' naocodificadora que poderiam ser responsáveis pela sua traduça preferencial (Klemenz et al., 1985; McGarry e Lindquist, $1985)$.

Nossos resultados também mostram que superposto ao controle do desenvolvimento exercido sobre a fosforilaça de 56, o choque térmico induz uma completa e especifica desfosforilaçăo de 56. Contudo durante a recuperaçăo, este controle do desenvolvimento é restabelecido. Assim, uma importante caracteristica da fosforilação de 56 parece ser a sua rápida resposta às variaçŏes nas condiçóes ambientais, sendo estas variações tanto capazes de estimular a fosforilação de 56 , tais como nutrientes ou fatores de crescimento (Thomas et al., 1982; Trevillyan et al., 1985; Blennis et al., 1984; Maller et al., 1985), ou capazes de estimular a desfosforilaçgo como o choque térmico (Glover, 1982; Scharf e Nover, 1982; Kennedy et al., 1984) ou outros estresses como por exemplo condiçós de hipertonicidade, (Kruppa e [lemens, 1984). 


\section{DISCUSSAO FINAL}

D ciclo de vida de Blastocladiella emersonii apresenta caracteristicas particularmente interessantes, que o tornam um conveniente modelo experimental para estudos sobre os mecanismos envolvidos no processo de diferenciaça celular. Durante as duas fases de diferenciaça deste microorganismo, esporulaçăo germinaçăo, ocorrem profundas mudanças na arquitetura celular, com alto grau de sincronia. Ho longo do processo de esporulaçă, que é induzido pela carência nutricional, ocorre uma série de mudanças morfológicas cujos principais marcos 5 ăo: aparecimento de um septo basal (60-90 min), formação da papila (100-120 min), inf́cio da formaça do flagelo (a150 min), clivagem do citoplasma ( $1180 \mathrm{~min}$ ) e (iberaçă dos zoósporos (210-240 min). Os zoósporos sgo células móveis e inativas com relaça à síntese de RNA e proteinas. Quando colocados em uma solução apropriada (meio inorgânico contendo potássio ou meio nutriente), os zoósporos rápida e sincronicamente retraem seu flagelo, formam uma fina parede de quitina e convertem-se em germes, num processo que requer menos de 60 minutos. Após a germinação os germes podem crescer se as condiçós nutricionais forem adequadas (Lovett, 1975).

Ds nossos resultados demonstraram que o processo de esporulaçăo reflete uma orástica mudança no programa de expressaro gênica. Rápidas variaçớes no padrão de proteínas sintetizadas nos diferentes estágios da esporulaçăo foram 
verificadas através de eletroforese bidimensional, sendo que muitas destas variaçŏes săo acompanhadas de uma variaça também na populaçao de mRNAs. Estes dados sugerem que o controle da expressá gênica durante esta fase de diferenciaçăo celular ocorre principalmente ao nível de transcriça diferencial, uma vez que o aumento da síntese da maioria das proteínas reflete diretamente a abundancia do seu mRNA. Dentre as proteínas cuja síntese é regulada pelo desenvolvimento, identificamos a actina, $\alpha$ e $\beta$-tubulinas, além de trés proteínas de choque térmico como serádiscutido adiante. 0 aumento na síntese dessas proteínas acompanha o acúmulo dos seus respectivos mRNAs. E interessante observar que o aumento na síntese de actina coincide com o infcio da citodiferenciaçăo dos zoósporos que resulta em uma célula altamente organizada. 0 aumento da sintese das tubulinas coincide com o período de formaça do flagelo, e de fato estas proteínas foram encontradas entre os componentes do flagelo.

A intensa renovaça de proteínas que ocorre durante a esporulaça correlaciona-se bem com os dados anteriores da literatura, de que a degradaça de proteínas é um evento essencial na conversão das células vegetativas em zoosporângios (Correa et al., 1978).

Observamos também, que a maior parte dos RNAs que sao sintetizados durante a esporulaçăo năo săo conservados nos zoósporos; estes resultados confirmam os dados de Jaworski e Thomson (1980) de que o RNA que é armazenado nos zoósporos é 
185.

sintetizado apenas nos 30 min finais da esporulaço. Desta observação surge um interessante aspecto. 0 processo de germinação dos zoósporos é pré-programado durante o final da esporulação apresentando um interessante paralelo com os sistemas de embriogênese animal (Davison, 1976). A maior parte do processo de germinaça não requer transcriça concomitante, e uma boa parte do aumento na sintese proteica que ocorre durante a germinaçă é resultado da traduçă das mRNAs transcritos durante a esporulaça e armazenado no zoósporo (5oll e Sonneborn, 1971a; Leaver e Lovett, 1974; Jaworski e Thomson, 1980; Silva et al., 1987a). Demonstramos que o RNA contido nos zósporos pode ser extraído em uma forma traduzivel "in vitro", e aparentemente năo existe distinçăo entre a populaçăo de RNA poli(A) + e poli(A)- .

Contudo, embora durante o inicio da germinaçăo năo tenhamos observado mudanças qualitativas no padrão de sintese proteica, indicando que os eventos iniciais da germinação săo inteiramente dirigidos pelos mRNAs armazenados nos zoósporo, na germinaçăo tardia verificamos a sintese de novas proteínas, tanto a partir de alguns mRNAs armazenados nos zoósporos que são tardia e seletivamente ativados para a tradução, como a partir de novos RNAs. Estas novas proteinas especificas da germinaça devem ser responsáveis por eventos relacionados ao processo de germinaçăo que nåo săo facilmente percebidos ao nível de rearranjos morfológicos, una vez que actinomicina $D$ năo inibe a transiçăo zoósporo --) germe. Elas podem também 
186.

estar envolvidas na elongaça e ramificacgo do rizóide que, como observado por Leaver e Lovett (1974), parece depender de sintese de novos mRNAs.

Quando a germinaçăo foi induzida em meio nutriente, observou-se a síntese de alguns polipeptidios exclusivos desta condiço de crescimento. Uma classe de genes, envolvidos no controle da proliferaça celular, também é seletivamente transcrita durante o crescimento em $\underline{\text { D. }}$ discoideum (Kopachik et al., 1985).

Ds eventos precoces do processo de germinaço aparentemente podem ocorrer mesmo na presensa de cicloeximida (Lovett, 1968; Soll e Sonneborn, 1971b). Assim esta fase da germinaçăo pode ser considerada um exemplo de diferenciaçăo celular na ausência de sintese proteica. Algumas modificações (variaçós de carga, degradaçăo especifica) das proteinas preexistentes no zoosporos foram detectadas. Assim, o processo de germinaçăo compreende múltiplos niveis de controle envolvendo controle a nivel de pós-traduçăo, traduçăo e transcriço diferencial de genes. Recentemente, foi relatado que a sintese proteica durante a germinaçăo aeróbica de M.racemosus, aparentemente, é regulada em múltiplos niveis compreendendo transcriça diferencial, processamento e traduço seletiva de RNAs (Linz e Drlowski, 1987).

Uma questão fundamental na biologia do desenvolvimento, é a natureza dos mecanismos que săo responsáveis pelo "ligal desliga" de genes envolvidos na progressaro ordenada do 
processo de diferenciaçăo celular. A observaça de que em Blastocladiella ambas as fases de diferenciação celular envolvem transcriça diferencial de genes, cujos produtos proteicos săo estágio-específicos, além de caracterizar melhor este sistema biológico, abre a perspectiva para o isolamento de genes envolvidos no processo de diferenciaça celular baseado na sua expressyo diferencial durante o ciclo de vida de B.emersonii. Este tipo de abordagem tem sido usada no isolamento de genes especificos do processo de formação de conídios em A.nidulans (Zimmerman et al., 1980) e Neurospora Crassa (Berlin e Yanofski, 1985b) bem como de genes regulados pelo desenvolvimento de D.discoideum que estăo envolvidos no processo de germinaçăo de esporos (Kelly et al., 1983) ou na agregaço celular (Chung et al., 1981).

D fato de que os genes relacionados com o desenvolvimento são expressos de uma maneira ordenada exclui a possibilidade de que eles sejam regulados de um modo independente e sugere algum tipo de controle hierárquico, no qual genes controladores orquestrariam a atividade de grupos de genes estruturais (Gehring, 1985).

A expressão gênica diferencial que ocorre durante a esporulação em B.subtilis é controlada pela expressaro de diferentes fatores sigma que redirecionam a especificidade da RNA polimerase para diferentes promotores (Losick e Youngman, 1984). O controle da expressäo de um grande número de genes, no caso da biogênese do flagelo em E.coli e crescentus, envolve uma cascata de fatores proteicos agindo 
188.

em "trans", que afetariam de uma maneira hierárquica a transcrição dos genes envolvidos na biogénese do flagelo e na expressăo de funçoses quimiotáticas (Komeda, 1982; Champer et al., 1987). A descoberta dos "homeo box" (sequências conservadas de 180 pares de base que foram encontradas nos genes homeóticos de Drosophila e que hipoteticamente codificam para uma proteina que poderia se ligar ao DNA, sendo responsável pela ativaçăo de conjuntos específicos de genes) aponta na direção de que devam existir proteinas reguladoras, responsáveis pela ativaça dos genes de desenvolvimento em eucariotos (Gehring, 1985, 1987).

Uma outra questão que procuramos responder foi saber até que ponto células diferenciadas respondem igualmente às variaçơses ambientais, como por exemplo choque térmico, que envolvem uma mudança abrupta no padrá de expressão gênica dessas células.

Dbservamos que a resposta ao choque térmico em Blastocladiella é dependente do estágio de desenvolvimento. Conjuntos específicos de Hsps (de um total de 22) 5 ão induzidos em cada fase do desenvolvimento cesporulaça, germinação e (rescimento), demonstrando, assim, uma expressăo năo coordenada dos genes de choque térmico. Estes conjuntos especificos de Hsps sa também induzidos durante a termotolerância. Porém, do total de 22 Hsps, apenas sete (Hsp82a, Hsp82b، Hsp76, Hsp70, Hsp60, Hsp25, Hsp17b) sðo induzidas pelo choque térmico em qualquer fase do desenvolvimento. Esta observaço nos levou a proposiçăo de 
189.

que estas sete Hsps é que estariam de fato envolvidas com o fenômeno de termoproteção induzido neste fungo.

Além dis5o, verificamos que durante fases especificas da esporulação, à temperatura fisiológica, ocorre a síntese de três proteínas de choque térmico (Hsp70, Hsp76 e Hsp39a). Todos os nossos dados apontam para uma identidade entre a Hsp70 induzida pelo choque térmico e a Hsp70 que aparece durante o desenvolvimento de Blastocladiella. Contudo, uma comprovaça mais definitiva de que năo se tratam de genes cognatos virá da análise da sequéncia gênica.

Nossos resultados somam-se aos recentes dados da Literatura que relatam a existencia, também em outros organismos, de uma regulaçăo do desenvolvimento superposta à ativaçăo transitória dos genes de choque térmico pelo calor. Existem fases do desenvolvimento ou tipos celulares onde certos genes hsps să ativos em condiçoes fisiológicas normais e outros onde certos genes hsps năo sao induzidos mesmo após o choque térmico (Zimmerman et al.,1983; Bensaude et al., 1983; Bensaude e Morange, 1983; Mason et al., 1984; Kurtz e Lindquist, 1984; Bienz, 1984; Morimoto e Fodor, 1984). Recentes observações feitas em nosso laboratório mostram que na bactéria C.crescentus ocorre a sintese de quatro Hsps $(70,62,24 b$ e 23b) em condiç8es normais de temperatura e que esta sintese está sob o controle do ciclo celular (Gomes et al., 1986). Mais especificamente durante a esporulaçăo, foi verificada a induçăo de Hsps em outros organismos como B.subtilis (Hsp84 e Hsp31) e em Levedura 
190.

(Hsp84, Hsp26 e proteínas da familia da Hsp70) (Todd et al., 1985; Kurtz et al., 1986). Além disso, a hipertermia exerce um papel na ativaçao da morfogênese em fungos patogénicos como Histoplasma capsulatum (Lambowitz et al, 1983) e em tripanosomatideos como Leishmania e Trypanosoma, induzindo a diferenciaça destes organismos para suas formas patogênicas (Hunter et al., 1984; Lawrence e Robert-Gero, 1985; Vander$P($ ag et a l., 1985).

Os mecanismos que regulariam a expressão espontânea, năo coordenada de genes de choque térmico bem como, a sua não indutibilidade pelo calor em certas fases do desenvolvimento ngo săo conhecidos. Bienz (1985) propôs a existência de dois tipos de mecanismos, baseando-se na descoberta da sequencia consenso HSE, existente nos promotores de vários genes de choque térmico, e também do fator HSTF, normalmente existente nas células e que, quando ativado, é capaz de reconhecer o elemento H5E (Pelham, 1985; Parker e Topol, 1984). Uma primeira possibilidade seria que quantidades limitantes de HSTF ativado, específicas para certos tipos celulares, associadas à variabilidade na potência da regia promotora de cada gene hsp, determinariam quais genes seriam ativados. Esta possibilidade poderia explicar a expressao do gene hsp83. sob condiçôes normais, em Drosophila - este gene possui um promotor forte contendo três HSEs, o que o tornaria indutivel mesmo em concentraçốes extremamente baixas de HSTF ativo, tal como estaria ocorrendo em células não estressadas. Qutra possibilidade 
seria a existencia de outros fatores, especificos de certos tipos de células, que reconheceriam elementos promotores, distintos de HSE, que estariam adjacentes apenas a certos genes hsp.

Recentemente foi demonstrado que a estimulaça mitogênica por adiçă de soro a células humanas em cultura induz um aumento da transcriga de genes hsp70 (Wu e Morimoto, 1985) e através de análise de deleções foi verificado que a região promotora destes genes contém pelo menos dois domínios regulatórios, um correspondente ao elemento HSE, que é responsável pela ativaça do gene durante o choque térmico e um outro contendo uma sequencia rica em purinas (gAagggaAARg) que é responsável pela ativaçao do gene em resposta à estimulaçao por soro (Wu et a (., 1986).

Nossos dados, apesar da ausência de informaçoes acerca da fungão das proteínas de choque térmico, reforçam a idéia de que as proteínas de choque térmico não estao meramente associadas com a proteção à hipertermia, devendo também exercer funçós metabólicas e estruturais importantes na célula. Como as necessidades estruturais e metabólicas do organismo variam durante o processo de desenvolvimento, a resposta ao estresse ambiental deve ser adaptada à situaço interna da célula no momento da agressão, levando à síntese de outras proteínas de choque térmico em adiça àquelas que sempre seriam necessárias para o inicio da resposta ao choque térmico. Tem sido proposto que a funça das proteínas 
de choque térmico é eliminar ou reparar protefnas danificadas, anormais ou desnaturadas, sendo que Hsp70 teria um papel no reparo dos nucleolos danificados durante o choque térmico (Pelham, 1985). Após o choque térmico, a Hsp70 inicialmente liga-se fortemente ao componente nuclear e em seguida ao nucléolo (Velasquez e Lindquist, 1984; Welch e Feramisco, 1984; Collier e Schlesinger, 1986). A Hsp70 tem uma alta afinidade por ATP (Welch e Feramisco, 1985) e a proteína análoga de E.coli (produto do gene dnak) tem uma atividade de ATPase (Zylicz et al., 1983).

Além disso tem sido proposto que o sistema de degradaçao das proteínas ligado a ubiqüitina, que também é uma proteína induzida por choque térmico (Bond e Schlesinger, 1985), seria responsável pelo disparo da resposta ao choque térmico (Munro e Pelham, 1985). Estes autores propuseram que certas proteínas como HSTF poderiam ser mantidas na célula ligadas a ubiqüitina, num sistema de equilibrio dinâmico; o aumento na concentraçăo de proteínas danificadas durante a hipertermia levaria a uma queda do nivel de ubiquitina, resultando no aumento da concentraça de HSTF na forma não ubiquitinada e que corresponderia à forma ativa do fator. Durante a esporulaça em Blastocladiella ocorre uma intensa renovaça de proteínas (5ilva et al., 1986) o que poderia ser correlacionado com a induçăo espontânea de algumas Hsps durante este processo.

A nossa observaçăo de que em Blastocladiella a resposta ao choque térmico é dependente do desenvolvimento 
proporcionou a oportunidade de investigar se existiria alguma relação entre o estado da fosforilaçăo da proteína ribossomal 56 e a traduça de mensagens específicas, que no caso estariam representadas pelas mensagens de choque térmico. Dados anteriores, obtidos em nosso laboratorio, demonstraram que, neste fungo, o estado de fosforilaça da proteína ribossomal SG varia durante o desenvolvimento e em resposta a certos sinais nutricionais, por exemplo adiça de extrato de levedura (Bonato et al., 1984). Estes resultados já mostravam que derivados altamente fosforilados de 56 nao eram necessários para o aumento da sintese proteica durante o crescimento do germe.

Nossos resultados sugerem uma correlaça entre a desfosforilaça de 56 e a traduça de uma classe definida de proteinas (Hsps), como encontrado por outros (Scharf e Nover, 1982; Kennedy et al., 1984), e que derivados de 56 altamente fosforilados parecem ngo ser essenciais à retomada da sintese proteica normal durante a recuperaça do choque térmico ( $5 i$ lva et al., 1987c).

E provável que o papel da fosforilaça de 56 na regulaçăo da traduçăo seja um tipo de controle muito mais fino do que previamente imaginado cou seja, que fosse essencial para a iniciaçăo da sintese proteica), ocorrendo em consonancia com outros possíveis mecanismos de controle, tais como estado de fosforilaça dos fatores de iniciaça, existência de diferentes sequências líderes nos mRNAs, etc. Para esclarecer a regulaçăo da fosforilaçăo de 56 bem como 
194.

se estudar "in vitro" a fungag dessa fosforilacao é essencial a purificaçăo e a caracterizaçăo da proteína quinase responsável pela fosforilaça de 56. Nesse sentido, estamos investigando a existencia de uma proteina quinase especifica para 56 em Blastocladiella e resultados preliminares mostraram a presença, em germes obtidos em meio DM3, de uma enzima que fosforila preferencialmente a subunidade 405 . 
Hbe, 5.5. e Lovett, J.5. (1982) Microtubular proteins and tubulin pool changes during zoospore germination in the fungus Blastocladiella emersonii. Arch. Microbiol. $131: 323-329$.

Adelman, T.G. e Lovett, J.S. (1974) Evidence for a ribossome-associated translation inhibitor during differentiation of Blastocladiella emersonii. Biochim. Biophys. Acta 335 : 236-245.

Affara, N.A., Robert, B., Jacquet, M., Buckingham, M.E. e Gros, F. (1980) Changes in gene expression during myogenic differentiation. I. Regulation of messenger RNA sequences expressed during myotube formation. J. Mol. Biol. $140: 441-458$.

Alton, T.H. e Lodish, H.F. (1977) Developmental changes in messenger RNAs and protein synthesis in Dictyostelium discoideum. Dev. Biol. 60:180-206.

Arce, [.A., Rodrigues, J.A., Barra, H.S. e [aputto, R. (1975) Incorporation of L-tyrosirie, L-phenylalanine and L-3,4-dihydroxyphenyalanine as single units into rat brain tubulin. Eur. J. Biochem. 59:145-149.

Atkinson, B.G. e Walden, D.B. (eds.) (1985) Changes in eukaryotic gene expression in response to environmental stress. Acad. Press, Inc. Drlando, Flórida.

Aviv, H. e Leder, P. (1972) Purification of biologically active globin messenger RNA by chromatography on oligothymidylic acid-cellulose. Proc. Natl. Acad. Sci. USA 69: 1408-1412.

Ballinger, D.G. e Hunt, T. (1981) Fertilization of sea urchin eggs is accompanied by 405 ribosomal subunit phosphorylation. Dev. Biol. 87:277-285.

Barbieri, C.L. e Camargo, E.P. (1975) Esterase activity during the life cycle of Blastocladiella emersonii. J. Bacteriol. 124:1626-1627.

Bardwell, J.C.A e [raig, E.A. (1984) Major heat shock gene of Drosophila and Escherichia coli inducible dnak gene are homologous. Proc. Natl. Acad. 5ci. U5A 81:84 $\overline{8-852}$.

Barstow, W.E. e Lovett, J.5. (1974) Apical vesicles and microtubules in rhizoids of Blastocladiella emersonii. Effects of actinomycin $D$ and cicloheximide on development during germination. Protoplasma 82:103-117. 
196.

Belasco, J.G.' Beatty, J.T., Adams, [.W., Von Gabain, A. e Cohen, S.N. (1985) Differential expression of photosynthesis genes in R. capsulata results from segmental differences in stability within the polycistronic rXcA transeript. Cell 40:171-181.

Bensaude, D., Babinet, L., Morange, M. e Jacob, F. (1983) Heat shock protein, first major products of zigotic gene activity in mouse embryo. Nature 305:331-333.

Bensaude, $D$. e Morange, M. (1983) Spontaneous high expression of heat-shock proteins in mouse embryanal carcinoma cells and ectoderm from day 8 mouse embryo. EMBO J. 2: 173-177.

Ben Ze'ev, A. (1986) The relationship between cytoplasmic organization, gene expression and morphogenesis. Trends Biochem. Sci. 11:478-481.

Ben Ze'ev, A., Farmer, 5.R. e Penman, 5. (1979) Mechanism of regulating tubulin synthesis in cultured mammalian cells. [ell 17:319-325.

Berger, E.M. e Woodward, M.P. (1983) Small heat shock proteins in Drosophila may confer thermal tolerance. Exp. Cell Res. 147:437-442.

Berlin, U. e Yanofski, C. (1985a) Protein changes during the asexual cycle of Neurospora crassa. Mol.Cell.Biol. 5:839848 .

Berlin, U. e Yanofski, C. (1985b) Isolation and characterization of genes differentially expressed during conidiation of Neurospora crassa. Mol. Cell. Biol. 5:849855 .

Bienz, M. (1984) Developmental control of the heat shock response in Xenopus. Proc.Natl. Acad.5ci.U5A 81:3138-3142.

Bienz, M. (1985) Transient and developmental activation of heat-shock genes. Trends Biochem. Sci. 10:157-161.

Bienz, M. e Gurdon, J.B. (1982) The heat shock response in Xenopus oocytes is controlled at the translational level. Cell 29:811-819.

Blenis, J., Spivack, J.G. e Erickson, R.L. (1984) Phorbol ester, serum, and Rous sarcoma virus transforming gene product induce similar phosphorylation of ribosomal protein 56. Proc. Natl. Acad. Sci. USA 81:6408-6412. 
Blerkom, J.V. (1981) Structural relationship and posttranslational modification of stage-specific proteins synthesized during early preimplantation development in the mouse. Proc. Natl. Acad. 5ci.U5A 78:7629-7633.

Bommer, U.A., Noll, F., Lutsch, G. e Bielka, H. (1980) Immunochemical detection of proteins in the small subunit of rat liver ribosomes involved in binding of ternary initiation complex. FEBS Lett. 111;171-174.

Bonato, M.C.M., Maia, J.C.C. e Juliani, M.H. (1985) Analysis of Blastocladiella emersonii ribosomal proteins in four two dimensional gel electrophoresis systems. Brazilian J. Med. Biol. Res. 18:143-150.

Bonato, M.C.M., Silva, A.M., Maia, J.C.C. e Juliani, M.H. (1984) Phosphorylation of ribosomal protein 56 in the aquatic fungus Blastocladiella emersonii. Eur. J. Biochem. 144:597-606.

Bonato, M.C.M., Silva, A.M., Gomes, S.L., Maia, J.C.C. e Juliani, M.H. (1987) Differential expression of heatshock proteins and spontaneous synthesis of HSP70 during the life cycle of Blastocladiella emersonii. Eur. J. Biochem. 163:211-220.

Bond, U. e Schlesinger, M.J. (1985) Ubiquitin is a heat shock protein in chichen embryo fibroblasts. Mol. Cell. Biol. $\underline{5}$ : 949-956.

Brandhorst, B.P. (1976) Two-dimensional gel patterns of protein synthesis before and after fertilization of sea urchin eggs. Dev. Biol. 52:310-317.

Brochetto-Braga, M.R., Gomes, 5.L. e Maia, J.C.C. (1982) Studies on the adenosine $3^{\prime}, 5^{\prime}$-monophosphate-dependent protein kinase of Blastocladiella emersonil. Arch. Biochem. Biophys. 217: 295-304.

Burdon, R.H. (1986) Heat shock and the heat shock proteins. Biochem. J. 240:313-324.

Burkhard, 5.J. e Traugh, J.A. (1983) Changes in ribosome function by cAMP-dependent and cAMP-independent phosphorylation of ribosomal protein 56. J. Biol. Chem. 258: 14003-14008.

Burland, T.G., Gull, K., Schedl, T., Boston, R.5. e Dove, W.F. (1983) Cell type-dependent expression of tubulins in Physarum. J. Cell Biol. 97:1852-1859. 
Burnette, W.N. (1981) "Western blotting": electrophoretic transfer of proteins from sodium dodecyl sulfatepolyacrylamide gels to unmodified nitrocellulose and radiographic detection with antibody and radioiodinated protein A. Anal. Biochem. 112:195-203.

Champer, R., Dingwall, A. e Shapiro, L. (1987) Cascade regulation of Caulobacter $f(a g e l l a r$ and chemotaxis genes. J. Mol. Biol. 194:71-80.

Chapppell, T.G., Welch, W.J., Schlossman, D.M., Palter, K.B., Schlesinger, M.J.e Rothman, J. (1986) Uncoating ATPase is a member of the $70 \mathrm{kilodalton} f a m i l y$ of stress proteins. Cell 45:3-13.

Chirgwin, J.M., Przybyla, R.E., MacDonald, R.J., e Rutter, W.J. (1979) Isolation of biologically active ribonucleic acid from sources enriched in ribonuclease. Biochemistry $18: 5294-5299$.

Chisholm, R.L., Fontana, D. . Theibert, R., Lodish, H.F. e Devreotes, P. (1984) Development of Dictyostelium discoideum: chemotaxis, cell-cell adhesion and gene expression. In: Microbial Development. R. Losick e L. Shapiro (eds.), Cold 5pring Harbor Laboratory, New York, pp. 219-254.

Chung, S., Landfear, 5.M., Blumberg, D.D., Cohen, N.S. e Lodish, H.F. (1981) Synthesis and stability of developmentally regulated Dictyostelium mRNAs are affected by cell-cell contact and cAMP. Cell 24:785-797.

Clayton, L., Pogson, C.I. e Gull, K. (1979) Microtubule proteins in the yeast, Saccharomyces cerevisiae. FEBS Lett. 106: 67-70.

Clayton, L., Duinlan, R.A., Roobol, A., Pogson, C.I. e Gull, K. (1980) A comparison of tubulins from mammalian brain and Physarum polycephalum using SDS-polyacrylamide gel electrophoresis and peptide mapping. FEBS Lett. 115:301305 .

Cleveland, D.W., Fischer, 5.G., Kirschner, M.W. e Laemmli, U.K. (1977) Peptide mapping by limited proteolysis in sodium dodecyl sulfate and analysis by gel electrophoresis. J. Biol. Chem. 252:1102-1106.

[leveland, D.W., Lopata, M.A., Sherline, P. e Kirschner, M.W. (1981) Unpolymerized tubulin modulates the level of tubulin mRNA. Cell 25:537-546.

Cleveland, D.W. e Sullivan, K.F. (1985) Molecular biology and genetics of tubulin. Ann. Rev. Biochem. 54:331-365. 
Collatz, E., Plesset, J., Foy, J.J. e Mclaughlin, C.S. (1985) Expression of the Drosophila 70000 dalton heat shock protein is translationally controlled in yeast. Yeast 1:49-56.

Collier, N.C. e Schlesinger, M.J. (1986) The dynamic state of heat shock proteins in chicken embryo fibroblasts. J. Cell Biol. 103:1495-1507.

Correa, J.U., Lemos, E.M. e Lodi, W.R. (1978) Inhibition of sporulation in the water mold Blastocladiella emersonii by antipain. Dev. Biol. 66:470-469.

Correa, J.U., Rodrigues, U. e Lodi, W.R. (1979) Proteases of Blastocladiella emersonii: developmental patterns and sensitivity to inhibitors in vitro and in vivo. In: International Conference on Limited Proteolysis in Microorganisms. G.N. Cohen e H. Holzer (eds.), U.S. Department of Health, Education and Welfare, Washington, D.C., PP. 127-130.

Craig, E.A. (1985) The heat shock response. CRC Crit. Rev. Biochem. 18:239-280.

Craig, E.A., Ingolia, T.D. e Manseau, L.J. (1983) Expression of Drosophila heat-shock cognate genes during heat-shock and development. Dev. Biol. 99:418-426.

[raig, E.A. e Jacobsen, K. (1985) Mutations in cognate genes of Saccharomyces cerevisiae hsp70 result in reduced growth rates at low temperatures. Mol. Cell. Biol. 5: $3517-3524$.

Davison, J.N. (1976) Gene activity in early development. Academic Press, Inc., New York.

De Benedetti, A. e Baglioni, C. (1986) Activation of heminregulated initiation factor-2 kinase in heat-shocked HeLa cells. J. Biol. Chem. 261:338-342.

Desmarquets, G., Cortay, J.C. e Cozzone, A.J. (1984) Twodimensional analysis of proteins phosphorylated in E.coli cells. FEBS Lett. 173:337-341.

Diggins, M.A. e Dove, W.F. (1987) Distribution of acetylated alpha-tubulin in Physarum polycephalum. J. Cell. Biol. 104: 303-309.

Duncan, R. e Hershey, J.W.B. (1984) Heat shock-induced translational alterations in Hela cells. Initiation factor modifications and the inhibition of translation. J. Biol. Chem. 259:11882-11889. 
Duncan, R. e Mcconkey, E.H. (1982) Rapid alterations in initiation rate and recruitment of inactive RNA are temporally correlated with 56 phosphorylation. Eur. J. Biochem. 123:539-544.

Eipper, B.A. (1972) Rat brain microtubule protein: Purification and determination of covalently bound phosphate and carboydrate. Proc. Natl. Acad. Sci. USA 69: 2283-2287.

Erickson, E. e Maller, J.L. (1986) Purification and characterization of a protein kinase from Xenopus eggs highly specific for ribosomal protein 56. J. Biol. Chem. $261: 350-355$.

Farmer, S.R. (1986) Actin. A regulator of cell growth and differentiation. In: Cell and Molecular Biology of the [ytoskeleton. J.W. Shay (ed.), Plenum Press, New York, pp. 131-149.

Freer, S.N. e Van Etten, J.L. (1978) Changes in messenger RNAs and protein synthesis during germination of Rhizopus stolonifer sporangiospores. Exp. Mycol. 2:313-325.

Fink, K. e Zeuthen, E. (1978) Heat shock proteins in Tetrahymena. ICN-UCLA Sympos. Mol.Cell. Biol. 12:103-115.

Garrels, J. e Hunter, T. (1979) Post-translational modification of actins synthesized in vitro. Biochem. Biophys. Acta 564:517-525.

Gehring, W.J. (1985) The homeo box: $A$ key to the understanding of development? Cell $40: 3-5$.

Gehring, W.J. (1987) Homeo box in the study of development. Science 236: 1245-1251.

Gerner, E.W. e 5chneider, M.J. (1975) Induced thermal resistance in Hela cells. Nature 256:500-502.

Glover, C.V.C. (1982) Heat shock induces rapid dephosphorylation of a ribosomal protein in Drosophila. Proc. Natl. Acad. Sci. 79:1781-1785.

Golden, J.W., Robinson, 5.J. e Haselkorn, R. (1985) Rearrangement of nitrogen fixation genes during heterocyst differentiation in the cyanobacterium Anabaena. Nature 314:419-423.

Goldstein, A. e Cantino, E.C. (1962) Light-stimulated polysaccharide and protein synthesis by synchronized single generations of Blastocladiella emersonii. J. Gen. Microbiol. 28:689-699. 
Gomes, S.L., Juliani, M.H., Maia, J.C.C. e Rangel-Aldao, R. (1983) Autophosphorylation and rapid dephosphorylation of the cAMP-dependent protein kinase from Blastocladiella emersonii zoospores. J. Biol. Chem. 258:6972-6978.

Gomes, 5.L., Juliani, M.H., Maia, J.C.C. e Silva, A.M. (1986) Heat shock protein synthesis during development in Caulobacter crescentus. J. Bacteriol. 168:923-930.

Gomes, 5.L., Mennuci, L. e Maia, J.C.C. (1978) Adenylate cyclase activity and cyclic AMP metabolism during cytodifferentiation of Blastocladiella emersonii. Biochim. Biophys. Acta 541: 190-198.

Gomes, S.L., Mennuci, L. e Maia, J.C.C. (1980) Induction of Blastocladiella emersonii germination by cyclic adenosine 3',5'-monophosphate. Cell Differ. 9:169-179.

Gomes, 5.L. e Shapiro, L. (1984) Differential expression and positioning of chemotaxis methylation proteins in Caulobacter. J. Mol. Biol. 178:551-568.

Gong, [.5. e Lovett, J.5. (1977) Regulation of protein synthesis in Blastocladiella zoospores: factors for synthesis in nonsynthetic spores. Exp. Mycol. 1:138-151.

Gordon, J., Nielsen, P.J., Manchester, K.L., Towbin, H., Jimenez de Asua, L. e Thomas, G. (1982) Criteria for establishment of the biological significance of ribosomal protein phosphorylation. In: Current Topics in cellular regulation. B.L.Horecker e E.R. Stadtman (eds.), Acad. Press, New York, vol 21, pp. 89-99.

Gottschalk, W.K. e Sonneborn, D.R. (1982) Phenotypic dissections of the Blastocladiella emersonii zoospore's developmental choice. Dev. Biol. 93:165-180.

Green, L.L. e Dove, W.F. (1984) Tubulin proteins and RNA during the myxamoeba-flagellate transformation of Physarum polycephalum. Mol. Cell. Biol. 4: 1706-1711.

Gressner, A.M. e Wool, I.G. (1974) The phosphorylation of Liver ribosomal proteins "in vivo" - Evidence that only a single small subunit protein (56) is phosphorylated. J. Biol. Chem. 249:6917-6925.

Hahn, G.M. e Li, G.C. (1982) Thermotolerance and heat shock proteins in mammalian cells. Radiat. Res. 92:452-457.

Hallberg, R.L., Wilson, P.G. e Sutton, C. (1981) Regulation of ribosome phosphorylation and antibiotic sensitivity in Tetrahymena thermophila: a correlation. Cell 26:47-56. 
Hall, B.G. (1983) Yeast thermotolerance does not require protein synthesis. J. Bacteriol. 156:1363-1365.

Hardy, S.J.5., Kurland, C.G., Voynow, P. e Mora, G. (1969) The ribosomal proteins of Escherichia coli. I. Purification of the 305 ribosomal proteins. Biochemistry $\underline{B}: 2897-2905$.

Hohn, T.M., Lovett, J.S. e Bracker, C.E. (1984) Characterization of the major proteins in gamma particles, cytoplasmic organelles in Blastocladiella emersonii zoospores. J. Bacteriol. 158:253-263.

Hood, L., Kronenberg, M. e Hunkapiller, T. (1985) T cell antigen receptors and the immnoglobulin supergene family. Cell 40: 225-229.

Hunt, [. e Morimoto, R.I. (1985) Conserved features of eukaryotic hsp70 genes revealed by comparison with the nucleotide sequence of human hsp70. Proc. Natl. Acad. $5 c i$. USA $82: 6455-6459$.

Hunter, K.W., Cook, C.L. e Hayunga, E.G. (1984) Leishmanial differentiation in vitro: induction of heat shock proteins. Biochem. Biophys. Res. Commun. 125:755-760.

Hussey, P.J. e Gull, K. (1985) Multiple isotypes of $a$ - and $\beta$-tubulin in the plant Phaseolus vulgaris. FEBS Lett. $\underline{181}: 113-118$.

Iida, H. e Yahara, I. (1984a) Durable synthesis of high molecular weight heat shock proteins in $G_{0}$ cells of the yeast and other eucaryotes. J. Cell Biol. 99:199-207.

Iida, H. e Yahara, I. (1984b) A heat shock-resistant mutant of Sacchaaromyces cerevisiae shows constitutive synthesis of two heat shock proteins and altered growth. J. [ell Biol. 99: 1441-1450.

Ingolia, T.D. e [raig, E.A. (1982a) Four small Drosophila heat shock proteins are related to each other and to mammalian alpha-crystallin. Proc. Natl. Acad. Sci. USA $79: 2360-2364$.

Ingolia, T.D. e [raig, E.A. (1982b) Drosophila gene related to the major heat shock-induced gene is transcribed at normal temperatures and not induced by heat shock. Proc. Natl. Acad. Sci. USA 79:525-529.

Ingolia, T.D., Craig, E.A. e McLarthy, B.J. (1980) Sequence of three copies of gene for the major Drosophila heat shock induced protein and their flanking regions. Cell 21: 669-679. 
Ingolia, T.D., Slater, M.R. e [raig, E.A. (1982) Saccharomyces cerevisiae contains a complex multigene family related to the major heat shock-inducible gene of Drosophila. Mol. Cell. Biol. 2:1388-1398.

Jackson, R.J. e Hunt, T. (1983) Preparation and use of nuclease-treated rabbit reticulocyte lysates for translation of eukaryotic messenger RNA. Meth. Enzym. 96: $51-74$.

Jantzen, H. (1981) Control of actin synthesis during development of Acantamoeba castellani. Dev. Biol. 82:113126 .

Jaworski, A.J. (1976) Synthesis of polyadenylic acid RNA during zoospore differentiation and germination in Blastocladiella emersonii. Arch. Biochem. Biophys. 173:201-209.

Jaworski, A.J. e Stumhofer, P. (1981) Stage. specific synthesis of proteins complexed to ribonucleoprotein particles and ribosomes in zoospores of Blastocladiella emersonii. Mol. Cell. Biol. 1:310-320.

Jaworski, A.J. e Stumhofer, P. (1983) Inhibiton of in vitro protein synthesis by subribosomal particles isolated from Blastocladiella emersonii zoospores. Exp. Mycol. 7:47-56.

Jaworski, A.J. e Stumhofer, P. (1984) Dormant ribosomes in Blastocladiella emersonii zoospores are arrested at elongation. Exp. Mycol. 吾: 13-24.

Jaworski, A.J. e Thomson, K. (1980) A temporal analysis of synthesis of mRNA sequestered in zoospores of Blastocladiella emersonii. Dev. Biol. 75:343-357.

Jaworski, A.J., Wu, W.B.L., Bateman, D.M. (1976) Metabolism of polyadenylic acid sequences during germination of Blastocladiella emersonii zoospores. Arch. Biochem. Biophys. 177:516-524.

Johnson, 5. e Lovett, J.S. (1984a) Base sequence complexity of the polyadenylated and nonpolyadenylated stored RNA in Blastocladiella zoospores. Exp. Mycol. 8:117-131.

Johnson, 5. e Lovett, J.5. (1984b) Gene expression during development of Blastocladiella emersonii. Exp. Mycol. B: $132-145$.

Johnson, S.A., Lovett, J.S. e Wilt, F.W. (1977) The poly adenylated RNA of zoospores and growth phase cells of the aquatic fungus, Blastocladiella. Dev. Biol. 56:329-342. 
Juliani, M.H., Brochetto, M.R. e Maia, J.C.C. (1979) Changes in cyclic AMP binding and protein kinase activities during growth and differentiation of Blastocladiella emersonii. Cell Differ. 8:421-430.

Juliani, M.H., Maia, J.C.C. e Bonato, M.C.M. (1983) Increased phosphorylation of a ribosomal protein during aggregation of the slime mold Dictyostelium discoideum. FEBS Lett. 154:400-406.

Kabat, D. (1970) Phosphorylation of ribosomal proteins in rabbit reticulocytes. Characterization and regulatory aspects. Biochemistry 9 :4160-4175.

Kelley, P.M. e Schlesinger, M.J. (1978) The effect of aminoacid analogues and heat shock on gene expression in chicken embryo fibroblasts. Cell 15:1277-1286.

Kelley, P. e Schlesinger, M.J. (1982) Antibodies to two major chicken heat shock proteins cross-react with similar proteins in widely divergent species. Mol. Cell. Biol. 2: 267-274.

Kelly, L.J., Kelly, R. e Ennis, H.L. (1983) Characterization of cDNA clones specific for sequences developmentally regulated during Dictyostelium discoideum spore germination. Mol. Cell. Biol. 3:1943-1948.

Kelly,R., Kelly, L.J.e Ennis, H.L. (1985) Dictyostelium discoideum mRNAs developmentally regulated during spore germination have short half-lives. Mol. Cell. Biol. 5: $133-139$.

Kennedy, I.M., Burdon, R.H. e Leader, D.P. (1984) Heat shock causes diverse changes in the phosphorylation of ribosomal proteins of mammalian cells. FEBS Lett. 169: $267-273$.

Kimmel, A.R. e Firtel, R.A. (1982) The organization and expression of the Dictyostelium genome. In: The Development of Dictyostelium discoideum. W.F. Loomis (ed.), Acad. Press, Inc., New York, pp. 233-324.

Kindle, K. L. e Firtel, R.A. (1978) Identification and analysis of Dictyostelium actin genes, a family of moderately repeated genes. Cell 15:763-778.

Kirk, M.M. e Kirk, D.L. (1985) Translational regulation of protein synthesis, in response to light, at a critical stage of Volvox development. Cell 41:419-428. 
Klar, A.J.S., Strathern, J.N. e Hicks, J.B. (1984) Developmental pathways in yeast. In: Microbial Development. R. Losick e L. Shapiro (eds.), Cold Spring Harbor Laboratory. New York pp. 151-195.

Klemenz, R., Hultmark, D. e Gehring, W.J. (1985) Selective translation of heat shock mRNA in Drosophila melanogaster depends on sequence information in the leader. EMBO J. 4: 2053-2060.

Komeda, $Y$. (1982) Fusions of $f$ lagellar operons to lactose genes on a Mu lac bacteriophage. J.Bacteriol. 150:16-26.

Kopachik, W., Bergen, L.G. e Barclay, S.L. (1985) Genes selectively expressed in proliferating Dictyostelium amoebae. Proc. Natl. Acad. 5ci. USA 82:8540-8544.

Kowit, J.D. e Fulton, [. (1974) Purification and properties of flagellar outer doublet tubulin from Naegleriagruberi and a radioimmune assay for tubulin. J. Biol. Chem. 249: $3638-3646$.

Krüger, C. e Benecke, B.J. (1981) In vitro translation os Drosophila heat shock and non-heat shock mRNA's in heterologous and homologous cell-free systems. Cell 23: $595-604$.

Kruppa, J. e Clemens, M.J. (1984) Differential kinetics of changes in the state of phosphorylation of ribosomal protein 56 and in the rate of protein synthesis in MPC11 cells during tonicity shifts. EMBD J. 3:95-100.

Kurtz, 5. e Lindquist, 5. (1984) Changing patterns of gene expression during sporulation in yeast. Proc. Natl. Acad. Sci. USA 81:7323-7327.

Kurtz, 5., Rossi, J., Petko, L. e Lindquist, 5. (1986) An ancient developmental induction: heat-shock proteins induced in sporulation and oogenesis. Science 231:11541157 .

Laemmli, U.K. (1970) Cleavage of structural proteins during the assembly of the head of bacteriophage $T_{4}$. Nature $227: 680-685$.

Lambowitz, A.M., Kobayashi, G.5., Painter, A. e Medoff, G. (1983) Possible relationship of morphogenesis in pathogenic fungus, Histoplasma capsulatum, to heat shock response. Nature 303:806-808.

Larsen, A. e 5ypherd, P.5. (1980) Physiological control of phosphorylation of ribosomal protein 56 in Mucor racemosus. J. Bacteriol. 141:20-25. 
Lastick, S.M. e Mcconkey, E.H. (1976) Exchange and stability of Hela ribosomal proteins "in vivo". J. Biol. Chem. 251: $2867-2875$.

Lawrence, F. e Robert-Gero, M. (1985) Induction of heat shock and stress proteins in promastigotes of three Leismania species. Proc. Natl. Acad. 5cí. U5A 82:44144417 .

Leader, D.P. (1980) The control of phosphorylation of ribosomal proteins. In: Molecular Aspects of Cellular Regulation. P. Cohen (ed.), Elsevier Biochemical, Amsterdam, vol 1, Pp. 203-234.

Leaver, [.J. e Lovett, J.5. (1974) An analysis of protein and RNA synthesis during encystment and outgrowth (germination) of Blastocladiella zoospores. Cell Differ. 当: $165-192$.

Leff, 5.E., Rosenfeld, M.G. e Evans, R.M. (1986) Complex transcriptional units: diversity in gene expression by alternative RNA processing. Ann. Rev. Biochem. 55:10911117 .

Lemeaux, P.G., Herendeen, S.L., Bloch, P.L. e Neidhart, F.C. (1978) Transient rates of synthesis of individual polypeptides in E.coli following temperature shifts. Cell 13 : $427-434$.

Lewis, M.J. e Pelham, H.R.B. (1985) Involvement of ATP in the nuclear and nucleolar functions of the $70 \mathrm{kd}$ heat shock protein. EMBO J. 4. $3137-3143$.

L'Hernault, S.W. e Rosenbaum, J.L. (1985) Chlamydomonas atubulin is post-translationally modified by acetylation on the E-amino-group of a lysine. Biochemistry 24:473478 .

Li, G.C. (1983) Induction of thermotolerance and enhanced heat shock protein synthesis in Chinese hamster fibroblasts by sodium arsenite and by ethanol. J. Cell. Physiol. 115:116-122.

Li, G.C. (1984) Elevated levels of 70,000 dalton heat shock protein in transiently thermotolerant Chinese hamster fibroblasts and their stable heat resistant variants. Int. J. Radiat. Oncol. Biol. Phys. 11:165-177.

Li, G.C. e Laszlo, A. (1985) Thermotolerance in mammalian cells: A possible role for heat shock proteins. In: Changes in Eukaryotic Gene Expression in Response to Environmental Stress. B.G. Atkinson e D.B. Walden (eds.), Acad. Press, Inc., Orlando, Florida, pp. 227-254. 
Li, G.C. e Werb, Z. (1982) Correlation between synthesis of heat shock proteins and development of thermotolerance in chinese hamster fibroblasts. Proc. Natl. Acad. Sci. USA 79: $3219-3222$.

Lindquist, 5. (1980) Translational efficiency of heatinduced messages in D. melanogaster cells. J. Mol. Biol. $137: 151-158$.

Lindquist, 5. (1981) Regulation of protein synthesis during heat shock. Nature 293:311-314.

Lindquist, S. (1986) The heat-shock response. Ann. Rev. Biochem. 55:1151-1191.

Lindquist, 5. e DiDomenico, B. (1985) Coordinate and noncoordinate gene expression during heat shock: A model for regulation. In: Changes in Eukaryotic Gene Expression in Response to Environmental Stress. B.G. Atkinson e D.B. Walden (eds.), Acad. Press, Inc., Orlando, Florida, pp. $71-90$.

Linz, J.E. e Orlowski, M. (1982) stored mRNA in sporangiospores of the fungus Mucor racemosus. J. Bacteriol. 150:1138-1144.

Linz, J.E. e Orlowski, M. (1987) Regulation of gene expression during aerobic germination of Mucor racemosus sporangiospores. J. Gen. Microbiol. 133: 141-147.

Loeb, J.E. e Blat, [. (1970) Phosphorylation of some rat liver ribosomal proteins and its activation by cyclic AMP. FEBS Lett. 10:105-108.

Lodi, W.R. e Sonneborn, D.R. (1974) Protein degradation and protease activity during the life cycle of Blastocladiella emersonii. J. Bacteriol. 117:1035-1042.

Loomis, W.F. e Wheeler, 5.A. (1980) The heat shock response of Dictyostelium. Dev. Biol. 79:399-408.

Loomis, W.F. e Wheeler, S.A. (1982) Chromatin associated heat shock proteins of Dictyostelium. Dev. Biol. 90:412418 .

Losick, R. e Youngman, P. (1984) Endospore formation in Bacillus. In: Microbial Development. R. Losick e L. Shapiro (eds.), Cold Spring Harbor Laboratory, New York, pp. $63-88$.

Lovett, J.S. (1968) Reactivation of ribonucleic acid and protein synthesis during germination of Blastocladiella zoospores and the role of ribosomal nuclear cap.J. Bacteriol. 96: 962-969. 
Lovett, J.5. (1975) Growth and differentiation of the water mold Blastocladiella emersonii. Cytodifferentiation and the role of ribonucleic acid and protein synthesis. Bacteriol. Rev. 34:345-404.

Lovett, J.5. (1983) Macromolecular synthesis in Blastocladiella. In: Fungal differentiation. A contemporarysynthesis. J.E. Smith (ed.) Marcel Dekker, Inc., New York, pp. 211-234.

Lowe, D.G. e Moran, L.A. (1984) Proteins related to the mouse L-cell major heat shock protein and synthesized in the absence of heat shock gene expression. Proc. Natl. Acad. Sci. USA 81:2317-2321.

Lowry, O.H., Rosebrough, N.J., Farr, A.L. e Randall, R.J. (1951) Protein measurement with the Folin phenol reagent. J. Biol. Chem. 193:265-275.

Maia, J.C.C. e Camargo, E.P. (1974) cAMP phosphodiesterase activity during growth and differentiation in Blastocladiella emersonii. Cell Differ. 3: 147-155.

Maia, J.C.C., Gomes, S.L. e Juliani, M.H. (1984) Preparation of (gamma-32P) and (alpha-32P) - nucleoside triphosphates with high specific activity. In: Genes and antigens of parasites. A laboratory manual. C.M. Morel (ed.) Fundaço Oswaldo [ruz, R.J. Pp. 139-149.

Maller, J.l., Foulkes, J.G., Erickson, E. e Baltimore, D. (1985) Phosphorylation of ribosomal protein 56 on serine after microinjection of Abelson murine leukemia virus tyrosine-specific protein kinase into Xenopus oocytes. Proc. Natl. Sci. USA 82:272-276.

Mangiarotti, G., Lefebure, P. e Lodish, H.F. (1982) Differences in the stability of developmentally regulated mRNAs in aggregated and disaggregated Dictyostelium discoideum cells. Dev. Biol. 89:82-91.

Maniatis, T., Fritsch, E.F. e Sambrook, J. (1982) Molecular cloning, a laboratory manual. Cold Spring Harbor Laboratory, Cold Spring Harbor, New York.

Margolskee, J.P. e Lodish, H.F. (1980) The regulation of synthesis of actin and two other proteins induced early in Dictyostelium discoideum development. Dev. Biol. $74: 5 \overline{0-64}$.

Mason, P.J., Hall., L.M.C. e Gausz, J. (1984) The expression of heat shock gens during normal development in Drosophila melanogaster. Mol. Gen. Genet. 194:73-78. 
McAlister, L. e Finkelstein, D.B. (1980a) Heat shock proteins and thermal resistance in yeast. Biochem. Biophys. Res. Commun. 93:819-824.

McAlister, L. e Finkelstein, D.B. (1980b) Alterations in translatable ribonucleic acid after heat shock of 5accharomyces cerevisiae. J. Bacteriol. 143:603-612.

McAlister, L., Strausberg, A., Kulaga, A. e Finkelstein, D.B. (1979) Altered patterns of synthesis induced by heat shock in yeast. Curr. Genet. 1:63-74.

McGarry, T.J. e Lindquist, 5. (1985) The preferential translation of Drosophila hsp70 mRNA requires sequences in untranslated leader. Cell 42:903-911.

Mckeithan, T.W., Lefebure, P.A., Silflow, C.D. e Rosenbaum, J.L. (1983) Multiple forms of tubulin in Polytomella and Chlamydomonas: evidence for a precursor of filagellar a-tubulin. J. Cell Biol. 96:1056-1063.

Morejohn, L.C. e Fosket, D.E. (1986) Tubulins from plants, fungi and protists. A review. In: Cell and Molecular Biology of the Cytoskeleton. J.W. Shay (ed.) Plenum Press, New York, pp. 257-329.

Morimoto, R. e Fodor, E. (1984) [ell-specific expression of heat shock proteins in chicken reticulocytes and lymphocytes. J. Cell Biol. 99:1316-1323.

Morrissey, J.H. (1981) Silver stain for proteins in polyacrylamide gels: A modified procedure with enhanced uniform sensitivity. Anal. Biochem. 117:307-310.

Munro, S. e Pelham, H. (1985) What turns on heat shock genes? Nature 317:477-478.

Murphy, M.N. e Lovett, J.S. (1966) RNA and protein synthesis during zoospore differentiation in synchronized cultures of Blastocladiella. Dev. Biol. 14:68-95.

Nakane, P.K. e Kawai, A. (1974) Peroxidase labelled antibody: a new method of conjugation. J. Histochem.

Cytochem. 22:1084-1091.

Neidhardt, F.C., VanBogelen, R.A. e Vaughn V. (1984) The genetics and regulation of heat-shock proteins. Ann. Rev. Genet. 18:295-329.

Nelson, D.R. e Zusman, D.R. (1983) Evidence for long-lived mRNA during fruiting body formation in Myxococcus xanthus. Proc. Natl. Acad. Sci. U5P 80:1467-1471. 
$\mathrm{Ng}, \mathrm{R}$. e Rbelson, J. (1980) Isolation and sequence of the gene for actin in 5accharomyces cerevise. Proc. Natl. Acad. Sci. USA ㄱ:3912-3916.

Nover, L. e Scharf, K.D. (1984) Synthesis, modification and structural binding of heat-shock proteins in tomato cells cultures. Eur. J. Biochem. 139:303-313.

Q'Farrell, P.H. (1975) High resolution two-dimensional electrophoresis of proteins. J. Biol. Chem. 250:40074021 .

O'Farrell, P.Z., Goodman, H.M. e O'Farrell, P.H. (1977) High resolution two-dimensional electrophoresis of basic as well as acidic proteins. Cell 12:1133-1142.

Olsen, A.5., Triemer, D.F. e Sanders, M.M. (1983) Dephosphorylation of 56 and expression of heat shock response in Drosophila melanogaster. Mol. Cell. Biol. $\underline{3}: 2017-2027$.

O'Malley, K. Mauron, A., Barchas, J.D. e Kedes, L. (1985) Constitutively expressed rat mRNA encoding a 70-kilodalton heat-shock-like protein. Mol. Cell. Biol. 5:34763483 .

Palatnik, C.M., Wilkins, C. e Jacobson, A. (1984) Translational control during early Dictyostelium development: possible involvement of poly(A) sequences. Cell 36:1017-1025.

Parker, [.S. e Topol, J. (1984) A Drosophila RNA polymerase I I transcription factor binds to the regulatory site of an hsp70 gene. Cell 37:273-283.

Pelham, H.R.B. (1982) A regulatory upstream promoter element in the Drasophila HSP70 heat shock gene. Cell 30:517-528.

Pelham, H.R.B. (1984) HSP70 accelerates the recovery of nucleolar morphology after heat shock. EMBO J. 3:30953100 .

Pelham, H.R.B. (1985) Activation of heat-shock genes in eukaryotes. Trends Gen. 1:31-35.

Pelham, H.R.B. e Jackson, R.J. (1976) An efficient mRNAdependent translational system from reticulocyte lysates. Eur. J. Biochem. 67:247-256.

Petko, L. e Lindquist, S. (1986) Hsp26 is not required for growth at high temperatures, nor for thermotolerance spore development, or germination. Cell 45:885-894. 
Phillips, T.R., VanBogelen, R.A. e Neidhardt, F.C. (1984) The lon (capR) gene product of Escherichiacoli is a heat-shock protein. J. Bacteriol. 159:283-287.

Plesofski-Vig, N. e Brambl, R. (1985) Heat shock response of Neurospora crassa: protein synthesis and induced thermotolerance. J. Bacteriol. 162:1083-1091.

Plesset, J., Palm, [. e McLaughin, [.S. (1982) Induction of heat shock proteins and thermotolerance by ethanol in Saccharomyces cerevisiae. Biochem. Biophys. Res. Commun. 108: 1340-1345.

Ritossa, F. (1962) A new puffing pattern induced by temperature shock and DNP in Drosophila. Experientia $\underline{18}: 571-573$.

Rosenthal, E.T., Hunt, T. e Ruderman, J.V. (1980) Selective translation of mRNA controls the pattern of protein synthesis during early development of the surf clam, Spisula solidissima. Cell 20:487-494.

Rosenthal, E.T., Brandhorst, B.P. e Ruderman, J.V. (1982) Translationally mediated changes in patterns of protein synthesis during maturation of starfish oocytes. Dev. Biol. $91: 215-220$.

Rubenstein, P. e Deuchler, J. (1979) Acetylated and nonacetylated actins in Dictyostelium. J. Biol. Chem. 254: $11142-11147$.

Russell, D.G., Miller, D. e Gull, K. (1984) Tubulin heterogeneity in the trypanosome Crithidia fasciculata. Mol. Cell. Biol. 4: $779-790$.

Russnak, R.H., Jones, D. e Candido, E.P.M. (1983) Cloning and anlaysis of cDNA sequences coding for two 16 $k i l o d a l t o n$ heat shock proteins (hsps) in Caenorhabditis elegans: homology with the small hops of Drosophila. Nucleic Acids Res. 11:3187-3205.

Sanders, M.M., Triemer, D.F. e Olsen, A.5. (1986) Regulation of protein synthesis in heat-shocked Drosophila cells. J. Biol. Chem. 261:2189-2196.

Sasse, R., Glyn, M.C.P., Birkett, C.R. e Gull, K. (1987) Acetylated a-tubulin in Physarum: immunological characterization of the isotype and its usage in particular microtubular organelles. J. Cell Biol. 104:4149.

Scharf, K.D. e Nover, L. (1982) Heat shock-induced alterations of ribosomal protein phosphorylation in plant cell cultures. [ell 30:427-437. 
Scheller, R.H., McAllister, L.B., Crain, Jr., W.R., Durica D.5., Posakony, J.W., Thomas, T.L., Britten R.J. e Davison, E.H. (1981) Drganization and expression of multiple actin genes in the sea urchin. Mol. Cell. Biol. $1: 609-628$.

Schlesinger, M.J. (1986) Heat shock proteins: the search for functions. J. Cell Biol. 103:321-325.

Schlesinger, M.J., Aliperti, G. e Kelley, P.M. (1982) The response of cells to heat shock. Trends Biochem. Sci. $\underline{7}: 222-225$.

Schlesinger, M.J., Ashburner, M. e Tissiéres, A. (1982) Heat shock from bacteria to man. Cold Spring Harbor Laboratory. Cold Spring Harbor, New York.

Schmoyer, I.R. e Lovett, J.S. (1969) Regulation of protein synthesis in zoospores of Blastocladiella. J. Bacteriol. $\underline{100}: 854-864$.

Scott, M.P. e Pardue, M.L. (1981) Translational control in lysates of Drosophila melanogaster cells. Proc. Natl. Acad. Sci. USA 78:3353-3357.

Selitrennikoff, C.P. e Sonneborn, D.R. (1977) Alkaline phosphatase of Blastocladiella emersonii: partial purification and characterization. J. Bacteriol. 130:249256 .

Sheir-Neiss, G., Lai, M.H. e Morris, N.R. (1978) Identification of a gene $\beta$-tubulin in Aspergillus nidulans. Cell 15:639-647.

Silva, A.M., Maia, J.C.C. e Juliani, M.H. (1986) Developmental changes in translatable RNA species and protein synthesis during sporulation in the aquatic fungus Blastocladiella emersonii. Cell Differ. 18:263274 .

Silva, A.M., Maia, J.C.C. e Juliani, M.H. (1987a) Changes in the pattern of protein synthesis during zoospore germination in Blastocladiella emersonii. J. Bacteriol. 169:2069- 2078 .

Silva, A.M., Juliani, M.H., Costa, J.J. e Bonato, M.C.M. (1987b) Acquisition of thermotolerance during development of Blastocladiella emersonii. Biochem. Biophys. Res. Commun. 144:491-498. 
Silva, A.M., Juliani, M.H. e Bonato, M.C.M. (1987c) Effect of heat shock on 56 phosphorylation during the development of Blastocladiella emersonii. Mol. Cell. Biochem. no prelo.

Silverman, P.M. (1976) Regulation of guanylate cyclase during cytodifferentiation of Blastocladiella emersoni Biochem. Biophys. Res. Commun. 70:381-388.

Silverman, P.M., Huh, M.M.-O. e Sun, L. (1974) Protein synthesis during zoospore germination in the aquatic phycomycete Blastocladiella emersonii. Dev. Biol. 40:5970 .

Smith, B.A. e Burke, D.D. (1979) Evidence for the presence of messenger ribonucleic acid in Allomyces macrogynus mitospores. J. Bacteriol. 138:535-541.

Soll, D.R. e Sonneborn, D.R. (1971a) Zoospore germination in Blastocladiella emersonii. III. Structural change in relation to protein and RNA synthesis. J. Cell Sci. gi:679-699.

Soll, D.R. e Sonneborn, D.R. (1971b) Zoospore germination in Blastocladiella emersonii: cell differentiation without protein synthesis? Proc. Natl. Acad. 5ci. USA 68:459-463.

Soll, D.R. e Sonneborn, D.R. (1972) Zoospore germination in Blastocladiella emersonii. IV. Ion control over cell differentiation. J. [ell Sci. 10:315-333.

Southern, E.M. (1975) Detection of specific sequences among DNA fragments separated by gel electrophoresis. J. Mol. Biol. 98:503-517.

Stadler, J., Gerisch, G., Baver, G. e Deppert, W. (1985) In vivo acylation of Dictyostelium actin with palmitic acid. EMBO J. $4: 1153-115 \overline{6}$.

Starti, R.V., Scott, M.P., Rich, A. e Pardue, M.L. (1980) Translational control of protein synthesis in response to heat shock in D. melanogaster cells. Cell 22:825-834.

Suprenant, K. , Hays, E., LeCluyse, E. e Dentler, W.L. (1985) Multiple forms of tubulin in the cilia and cytoplasm of Tetrahymena termophila. Proc. Natl. Acad. Sci. USA 82:6908-6912.

Takahashi, Y. e Ogata, K. (1981) Ribosomal proteins crosslinked to natural mRNA by UU irradiation of rat liver polysomes. J. Biochem. 90:1549-1552. 
Terao, K. e Ogata, K. (1979) Proteins of 5 mall subunits of rat liver ribosomes that interact with poly (U). I. Effects of preincubation of poly (U) with 405 subunits on the interactions of 405 subunit proteins with aurintricarboxylic acid and with $N, N^{\prime}-p-p h e n y l e n e-$ dimaleimide. J. Biochem. 86:597-603.

Thomas, G., Martin-Perez, J. Siegmann, M. e Otto, A.M. (1982) The effect of serum, EGF, PGF 2 a and insulin on 56 phosphorylation and the initiation of protein and DNA synthesis. Cell $30: 235-242$.

Tissieres, A., Mitchell, H.K. e Tracy, U.M. (1974) Protein synthesis in salivary glands of Drosophila melanogaster: Relation to chromossome puffs. J. Mol. Biol. 84:389-398.

Todd, J.A., Hubbard, T.J.P., Tavares, A.A. e Ellar, D.J. (1985) Heat shock proteins during growth and sporulation of Bacillus subtilis. FEBS Lett. 188:209-214.

Topol, J., Ruden, D.M. e Parker, C.5. (1985) Sequences required for in vitro transcriptional activation of a Drosophila hsp70 gene. Cell 42:527-537.

Towbin, H., Sthaehelin, T. e Gordon, J. (1979) Electrophoretic transfer of proteins from polyacrylamide gels to nitrocellulose sheets: Procedure and some applications. Proc. Natl. Acad. Sci. USA 76:4350-4354.

Traugh, J.A. (1981) Regulation of protein synthesis by phosphorylation. In: Biochemical Actions of Hormones. G. Litwack (ed.), Acad. Press, Inc., New York, vol 8, pp. $167-208$.

Traugh, J.A. e Pendergast, A.M. (1986) Regulation of protein synthesis by phosphorylation of ribosomal protein 56 and Aminoacyl-tRna synthetases. Prog. Nucleic Reid Res. $33: 195-230$.

Trevillyan, J.M., Perisic, 0., Traugh, J.A. e Byus, C.V. (1985) Insulin- and phorbol ester-stimulated phosphorylation of ribosomal protein 56. J. Biol. Chem. 260: $3041-3044$.

Vale, M.R. e Maia, J.C.C. (1976) Changes in cGMP phosphodiesterase levels during growth and differentiation in Blastocladiella emersonii. FEBs Lett. 70:205-208.

Van der Ploeg, L.H.T., Giannini, 5.H. e Cantor, C.R. (1985) Heat shock genes: regulatory role for differentiation in parasitic protozoa. Science 228:1443-1446. 
Velazquez, J.M. e Lindquist, 5. (1984) Hsp70: nuclear concentration during environmental stress and cytoplasmic storage during recovery. Cell 36:655-662.

Voellmy, R., Brombley, P. e Kocher, H.P. (1983) Structural similarities between corresponding heat-shock proteins from different eucaryotic cells. J. Biol. Chem. 258:35163522 .

Volloch, U. e Housman, D. (1981) stability of globin mRNA in terminally differentiating murine erythroleukemia cells. Cell 23:509-514.

Wadsworth, 5.[. (1982) A family of related proteins is encoded by the major Drosaphila heat shock gene family. Mol. Cell. Biol. 2:286-292.

Weir-Thompson, E.M. e Dawes, I.W. (1984) Developmental changes in translatable RNA species associated with meiosis and spore formation in Saccharomyces cerevisiae. Mol. Cell. Biol. 4:695-702.

Welch, W.J. e Feramisco, J.R. (1984) Nuclear and nucleolar localization of the 72,000-dalton heat shock protein in heat-shocked mammalian cells. J.Biol.Chem. 259:4501-4513.

Welch, W.J. e Feramisco, J.R. (1985) Rapid purification of mammalian 70,000-dalton stress proteins: affinity of the proteins for nucleotides. Mol. Cell. Biol. 5: 1229-1237.

Welch, W.J. e Suhan, P. (1985) Morphological study of the mammalian stress response: characterization of changes in cytoplasmic organelles cytoskeleton, and nucleoli, and appearance of intranuclear actin filaments in rat fibrobalsts after heat shock treatment. J. Cell Biol. 101: 1198-1211.

Wells, D.E., Showman, R.M., Klein, W.H. e Raff, R.A. (1981) Delayed recruitment of maternal histone $H 3$ mRNA in sea urchin embryos. Nature 292:477-478.

Wettenhall, R.E.H. e Morgan, F.J. (1984) Phosphorylation of hepatic ribosomal protein 56 on 80 and 405 ribosomes. Primary structure of 56 in the region of the major phosphorylation sites for cAMP-dependent protein kinases. J. Biol. Chem. 259:2084-2091.

White, E., Tolbert, E.M. e Katz, E.R. (1983) Identification of tubulin in Dictyostelium discoideum: characterization of some unique properties.J. Cell Biol. 97:1011-1019. 
Widelitz, R.B., Magun, B.E. e Gerner, E.W. (1986) Effects of cycloheximide on thermotolerance expression, heat shock protein synthesis, and heat shock protein mRNA accumulation in rat fibroblasts. Mol. Cell. Biol. 6: 10881094.

Winkler, M.M., Nelson, E.M., Lashbrook, [. e Hershey, J.W.B. (1985) Multiple levels of regulation of protein synthesis at fertilization in sea urchin eggs. Dev. Biol. 107:290300 .

Wray, W., Boulikas, T., Wray, U.P. e Hancock, R. (1981) Silver staining of proteins in polyacrylamide gels. Anal. Biochem. 118:197-203.

Wu, B.J., Kingston, R.E. e Morimoto, R.I. (1986) Human HSP70 promoter contains at least two distinct regulatory domains. Proc. Natl. Acad. 5ci. USA 83:629-633.

Wu, B.J. e Morimoto, R.I. (1985) Transcription of the human hsp70 gene is induced by serum stimulation. Proc. Natl. Acad. Sci. USA 82:6070-6074.

Wu, C. (1984) "TATA" and upstream regulatory sequences are protected from exonuclease III cleavage in chromatin. Nature 309:229-234.

Yamamori, T., Ito, K., Nakamura, Y. e Yura, I. (1978) Transient regulation of protein synthesis in Escherichia coli upon shift up of growth temperature. J. Bacteriol. 134:1133-1140.

Yamamori, T. e Yura, I. (1982) Genetic control of heat-shock protein synthesis and its bearing on growth and thermal resistance in Escherichia coli. Proc. Natl. Acad. Sci USA 79: $860-864$.

Zimmerman, C.R., Grr, W. L., Leclerc, R.F. Barnard, E.C. e Timberlake, W.E. (1980) Molecular cloning and selection of genes regulated in Aspergillus development. Cell 21: 709-715.

Zimmerman, J.C., Petri, W. e Meselson, M. (1983) Accumulation of a specific subset of Drosophila melanogaster heat shock mRNAs in normal development without heat shock. Cell $32: 1161-1170$.

Zylicz, M., LeBowitz, J.H., McMacken, R. e Georgopoulos, [. (1983) The dnaK protein of Escherichia coli possesses an ATPase and autophosphorylation activity and is essential in an in vitro DNA replication system. Proc. Natl. Acad. Sci. USA 80:6431-6435. 